\title{
Mestizaje: The All-Inclusive Fiction
}

\author{
Linnete Manrique-Robles \\ $\mathrm{PhD}$ candidate in Media and Communications \\ Goldsmiths, University of London \\ Primary Supervisor: Sara Ahmed \\ Secondary Supervisor: Gareth Stanton
}




\section{Declaration Page}

Declaration of Authorship: I, Linnete Manrique-Robles, hereby declare that this thesis and the work presented in it is entirely my own. Where I have consulted the work of others, this is always clearly stated.

Signature: Linnele M. Date: $\underline{5 \text { February } 2018}$ 


\section{Acknowledgements}

This research project first emerged six years ago. It began as a study of the politics of representation and whiteness in Mexican telenovelas in an MA course at New York University, and evolved into an interdisciplinary piece that explores how race and nation become entangled across different aspects of Mexican national culture with my exposure to postcolonial and critical race studies scholarship at Goldsmiths, University of London. Of particular influence was the course entitled "Race, Empire and Nation," which focused on how contemporary racial and national formations are intimately linked to longer histories of Western imperialism. The course's reading list that included Edward Said, Anne McClintock, Achille Mbembe and many others greatly informed the direction of this dissertation. First and foremost, I am grateful to Professor Sara Ahmed for convening this course, for exposing young students to important scholarship and for demonstrating that a decolonized curriculum in academia is not only feasible but necessary. Moreover, I am thankful to Professor Ahmed for acting as my primary supervisor and for offering me invaluable intellectual support and guidance throughout three challenging years. I would also like to thank Professor Ahmed for having founded the Feminist Postgraduate Forum and the Centre for Feminist Research at Goldsmiths, both of which opened up for me the world of critical feminist scholarship and created safe spaces for a diverse community of women to come together to share their stories. I would like to thank Professor Gareth Stanton for taking on the role of secondary supervisor on short notice and at a crucial time for me. I would like to thank the Media and Communications department and the Graduate School at Goldsmiths for their reliable financial support. 
Finally, I would like to extend my gratitude to Professor Sarah Sarzynski and Professor Juan Piñón from my previous academic institution, NYU. The former taught me the importance of treating Latin American popular culture as a serious topic of academic inquiry. It was in her course entitled "Race, Gender and Popular Cultural Theory in Latin America" that I first became aware of how the notions of race and mestizaje in Mexico exist in a complex relationship to histories of colonialism. In this course, I also gained the critical tools needed to make the familiar strange. Perhaps more than others, these two courses have shaped my thinking, writing and the contours of this dissertation. Professor Juan Piñón for his part encouraged me to continue pursuing an academic career and believed I could succeed at a time when I was plagued with doubt. And of course, I am grateful to the new friendships I built while in London, to the old friendships that are scattered throughout the United States and Mexico, and to my family for keeping me together with their patience, understanding and love. 


\begin{abstract}
This project examines the historical development of the ideology of mestizaje (racial and cultural mixture) in relation to the making of Mexico as a nation and the consolidation of the figure of the mestizo as the official national race. I am concerned with how mestizaje circulates and is (re-) produced across the public arena of politics, education and popular culture, and how it becomes part of everyday life. I also explore how mestizaje has been re-imagined with the concurrent rise of neoliberalism and multiculturalism from the 1990s onward. My ultimate goal with this dissertation is to show how race and racism remain implicated in Mexican nationalism as they serve to determine the terms of belonging to the nation.
\end{abstract}




\section{Contents}

1 - Introduction 7

2 - Race and Nation in Mexico 41

3 - Making the Nation: The Myth of Mestizaje 67

4 - Dreaming of a Cosmic Race: José Vasconcelos and the Politics of Race 96

5 - The Quest to Define the Mexican National Character 129

6 - Populist Politics: Indigenismo and Educational Telenovelas in Mexico 161

7 - From Mestizo to Multicultural: Debating National Identity in Neoliberal Mexico 199

8 - Chronicles of Race and Class on Late-Night Television 242

9 - Conclusion 271

Bibliography 297 


\section{Chapter One}

\section{Introduction}

"Much of our planet is convulsed with conflicts based on race, regionalism or culture. Mexico, on the whole, isn't. Our culture is generally inclusive. Almost the entire population of the country is mestizo, of mixed origin, American Indian and Spanish. In some areas (and in some minds), lingering bigotry toward 'Indians' persists, but it is by no means widespread.” - Enrique Krauze, Bloomberg View, 2011

"[In Mexico] one discriminates against the poor and not races. Here one discriminates against the indigenous not because of their race but because they are poor." - Rogelio Naranjo, La Jornada, 2005.

"In Mexico, unlike what occurs in the United States, our treatment of blacks has been more affectionate.” - Elena Poniatowska, La Jornada, 2005.

I begin with these epigraphs that posit Mexico as a tolerant, loving and inclusive nation, where racial differences are insignificant, to underscore the endurance of the dominant ideology of mestizaje. The term "mestizaje" is derived from the Latin mixtus (meaning "mixed") and denotes the mixture of different races and cultures. Mestizaje can be deployed as a conceptual category to describe the synthesis of multiple cultures and the subsequent origin of an entirely new culture. As such, mestizaje can be interchangeable with the terms "hybridity" and "syncretism." However, as I make evident throughout this research project, embracing mestizaje as a free-for-all process of intercultural transformation is problematic because it obscures the fact that this concept is rooted in the histories of colonialism, racism and nation building across the Americas.

The principal objective of this dissertation is to explore how the mestizaje ideology, which celebrates the status of being mixed as a positive aspect of national identity, historically developed in twentieth century Mexico and how it persists today. The aim that animates this project is to track what social and political work mestizaje does as it moves from the restricted domains of anthropology, history and philosophy into 
the more popular domain of television. I am interested in exploring how race and nation become entangled as mestizaje moves across time and space, as well as what histories are evoked by this mobility. In determining the shape and direction of this project, I was influenced by the works of various scholars, such as Anne McClintock, Edward Said, Wendy Brown and Sara Ahmed, who have traced the histories of words to account for what persists in the present. ${ }^{1}$

Although the focus of the thesis is on Mexico, it should be noted that mestizaje is a phenomenon widespread across Latin America. Historian Nicola Miller notes that Latin American intellectuals, most of whom were predominantly white, were among the first to name and advance archetypes of mestizaje as a reaction against the racial pessimism of European scientific theories, such as social Darwinism and positivism, and contributed to the nation-building projects. She adds that Mexico is considered one of the most successful countries in the region in its efforts to establish a national identity based on mestizaje - to the extent that the terms "Mexican" and "mestizo" became equivalent. The Mexican state embraced mestizaje as part of its larger project of modernization, which sought to assimilate the seemingly backward indigenous peasants into a modern mestizo labor force. ${ }^{2}$ Anthropologist Ronald Stutzman comments that mestizaje is best understood as "an all-inclusive ideology of exclusion" because while it purports that all Mexican citizens are of mixed blood and of equal status, it is shaped by racial hierarchies that

\footnotetext{
${ }^{1}$ Anne McClintock, Imperial Leather: Race, Gender and Sexuality in the Colonial Contest (London and New York: Routledge, 1995). Edward Said, Orientalism ( ${ }^{\text {rd }}$ ed.) (London: Penguin Books, 2003). Wendy Brown, Undoing the Demos: Neoliberalism's Stealth Revolution (Brooklyn, NY: Zone Books, 2015). Sara Ahmed, The Promise of Happiness (Durham and London: Duke University Press, 2010).

${ }^{2}$ Nicola Miller, In the Shadow of the State: Intellectuals and the Quest for National Identity in Twentieth-Century Spanish America (London and New York: Verso, 1999), 138.
} 
privilege whiteness and devalue indigenousness and blackness. ${ }^{3}$ For example, scholars have pointed out how the African legacy in Mexico has been omitted from the statesponsored schoolbooks, which contributes to the erasure of blackness from the collective imaginary. ${ }^{4}$ Representations of indigenous peoples ${ }^{5}$ in these books for their part focus on the grandeur and glory of the Aztec past, but ignore their heterogeneity and contemporary realities. ${ }^{6}$ Furthermore, images of white beauty are pervasive in advertisements, television and film. ${ }^{7}$

As evident in the epigraphs, prominent Mexican intellectuals today continue to rely on the myth of mestizaje to disavow racism, usually by subsuming it under class differences, projecting it outward (the US) and/or framing it as an isolated incident. This points to the need to understand mestizaje as an ongoing project that resonates across the culture at large and affects the everyday life of people. As social anthropologist Peter

\footnotetext{
${ }^{3}$ Ronald Stutzman, "El Mestizaje: An All-Inclusive Ideology of Exclusion," in Cultural Transformations and Ethnicity in Modern Ecuador, ed. Norman E. Whitten (Urbana, IL: University of Illinois Press, 1981), 45-94.

${ }^{4}$ Mónica Moreno Figueroa and Emíko Saldívar, “"We are Not Racists, We are Mexicans:' Privilege, Nationalism and Post-Race Ideology in Mexico," Critical Sociology, (2015): 1-19. Héctor Fernández L'Hoeste, "De estereotipos vecinos: Memín Pinguín como una oportunidad perdida," Revista Latinoamericana de Estudios Sobre la Historieta, 6 (2009): 144-154. Jennifer A. Meri Jones, “"Mexicans Will Take the Jobs that Even Blacks Won't Do:' An Analysis of Blackness, Regionalism and Invisibility in Contemporary Mexico," Ethnic and Racial Studies, 36 (2013): 1564-1581.

${ }^{5}$ On the issue of naming: I find the term "indigenous peoples" to be the most appropriate descriptor of Mexico's native population in order to highlight that they are not a monolithic group. The word "Indian" (or "indio"), which homogenizes and has been used disparagingly in Mexican culture, only appears in direct quotes on the texts I engage with throughout the thesis.

${ }^{6}$ Natividad Gutiérrez, Nationalist Myths and Ethnic Identities: Indigenous Intellectuals and the Mexican State (Lincoln, NE: University of Nebraska Press, 1999).

${ }^{7}$ Alan Knight, "Racism, Revolution, and Indigenismo: Mexico, 1910-1940," in The Idea of Race in Latin America, 1870-1940, ed. Richard Graham (Austin, TX: University of Texas Press, 1990), 71-113. Hugo G. Nutini, "Class and Ethnicity in Mexico: Somatic and Racial Considerations," Ethnology, 36 (1997): 227-238.
} 
Wade argues, mestizaje is not only a nation-building ideology but it is also "a lived process that operates within the embodied person and within networks of family and kinship relations." ${ }^{8}$ The recent works of sociologists Christina Sue and Moreno Figueroa are important contributions to the critical scholarship on mestizaje because they unravel how the logics of this ideology function on a personal level - for example, how dark skin color and other phenotypes associated with indigenousness and blackness can produce in people feelings of shame and inadequacy, and can have a negative impact on their access to education and employment. ${ }^{9}$

This dissertation is rooted in the humanities academic tradition, as I am more interested in tracing the history of mestizaje as an idea. I am not asking here what mestizaje is but what does it do as it travels: how did mestizaje come into being as a category in the first place? How was it first theorized in the written works of various intellectuals? How did it mutate when adopted by the post-revolutionary Mexican state? How did it acquire meaning through its circulation and reproduction across culture? This research project takes on a historical character even when addressing issues of representation in the media, for "any analysis of Mexican racism demands some grasp of Mexican race relations as they have historically developed."10

In these introductory pages, I delve into the subject of how I approach mestizaje by describing my research materials, methodology and the overall structure of the

\footnotetext{
${ }^{8}$ Peter Wade, "Rethinking Mestizaje: Ideology and Lived Experience," Journal of Latin American Studies, 37(2005): 239

${ }^{9}$ Christina Sue, Land of the Cosmic Race: Race Mixture, Racism, and Blackness in Mexico (New York and Oxford: Oxford University Press, 2013). Mónica Moreno Figueroa, "'Linda Morenita': Skin Colour, Beauty and the Politics of Mestizaje in Mexico," in Cultures of Colour: Visual, Material, Textual, ed. Chris Horrocks (New York and Oxford: Berghahn Books, 2012), 167-180.

${ }^{10}$ Knight, "Racism, Revolution, and Indigenismo," 72.
} 
dissertation. In the first section, I draw from the scholarship on archives to discuss the decisions involved in assembling my own archive around mestizaje, such as which texts and time periods to include and which to exclude in order to make the archive manageable. The second section takes my first unit of analysis, which includes essays and monographs of an anthropological, philosophical, historical and sociological nature, to explore the relationship between intellectuals and the state. I examine the role of intellectuals and the state in consolidating mestizaje as the basis of Mexican nationalism in order to emphasize that texts do not exist in isolation, but are entangled with other histories - histories of the state and its institutions, for example. The third section takes the second unit of analysis, which includes television programs and films, to investigate the importance of the mass media in reinforcing a single, mestizo national identity. Since my aim is to track the history of an idea and where that idea travels, I review my research materials here in order to underscore how they have fundamentally shaped the dissertation from the outset. In the final section, I provide a self-reflexive discussion on how my positioning in Mexico and in other national contexts has informed the project.

\section{Building an Archive}

The methodological question that any student of the humanities must address, as literary critic Said observes, is how to find and formulate a beginning. Beginnings do not simply exist or are already determined, but "have to be made for each project in such a way as to enable what follows from them" (emphasis in original). ${ }^{11}$ Said further notes, "the act of beginning necessarily involves an act of delimitation" in order to cut down a

${ }^{11}$ Said, Orientalism, 16. 
sizable body of work into manageable dimensions. ${ }^{12}$ The scholarship on mestizaje is rich and varied, and the seemingly endless possibilities for dealing with this topic can be overwhelming. A useful starting point is to decide whether to focus on mestizaje on a national leve $1^{13}$ or a regional one, comparing and contrasting Latin American countries. ${ }^{14}$ I decided to study mestizaje in the Mexican national context, staying close to "home," but the challenge remained to sort out which texts would form my archive and to what ends.

Before discussing my archive, it is worth reflecting on what do we mean when we talk about archives. Media historians Craig Robertson and Jeremy Packer describe the archive as "a technology for the collection, classification, and circulation of information," which is mobilized to structure, authorize and legitimize narratives of history. ${ }^{15}$

Robertson adds that the archive is bound to be "incomplete and unstable," for it excludes as much as it includes. Moreover, Michel Foucault explains that the archive cannot be described in its totality because "it does not constitute the library of all libraries, outside

\footnotetext{
${ }^{12}$ Ibid.

${ }^{13}$ Claudio Lomnitz, "The Origins of our Supposed Homogeneity: A Brief Archeology of National Unity in Mexico," Prismas, 14 (2010): 17-36. Olivia Gall, "Mexican LongLiving Mestizophilia Versus a Democracy Open to Diversity," Latin American and Caribbean Ethnic Studies, 8 (2013): 280-303. Alexandre Emboaba Da Costa, "Confounding Anti-Racism: Mixture, Racial Democracy, and Post-Racial Politics in Brazil," Critical Sociology, (2014): 1-19.

${ }^{14}$ Florencia E. Mallon, "Constructing Mestizaje in Latin America: Authenticity, Marginality, and Gender in the Claiming of Ethnic Identities," Journal of Latin American Anthropology, 2 (1996): 170-181. Marilyn G. Miller, Rise and Fall of the Cosmic Race: The Cult of Mestizaje in Latin America (Austin, TX: University of Texas Press, 2004). Peter Wade, Race and Sex in Latin America (London: Pluto Press, 2009). ${ }^{15}$ Craig Robertson, Media History and the Archive (London and New York: Routledge, 2011), 5. Jeremy Packer, "What is an Archive? An Apparatus Model for Communications and Media History," in Media History and the Archive, ed. Craig Robertson (London and New York: Routledge, 2011), 94.
} 
time and place." 16 The archive rather emerges "in fragments, regions, and levels," which we are able to understand more fully "the greater the time that separates us from it."17 Drawing from Foucault, historian Antoinette Burton observes that archives are not "innocent of struggles for power in either their creation or their interpretive applications." 18 For this reason, we must look into how archives are "constructed, policed, experienced, and manipulated," and for what purposes. ${ }^{19}$ Similarly, media studies scholar Susan Douglas points out that all archives "have their own biases on the basis of inclusion, omissions, and point of view, and the ones we make are no exception." ${ }^{20}$ However, the ones we create can serve as "a counterbalance" to official and institutional archives.

Building an archive requires a systematic approach to how research materials are selected and to how a chronology is established. Determining a set of criteria before starting the research is important to prevent us from looking for only what we want to find or for what confirms our preexisting arguments - the archive should surprise us. Writing from personal experience, Douglas comments that building her own archive has allowed her to see the evolution of certain ideas and trends, to track "the momentum [they] develop, their origin and roots, and how and when they start to come together and then explode." 21 This statement is apposite to what I hope to accomplish in this project,

\footnotetext{
${ }^{16}$ Michel Foucault, The Archaeology of Knowledge and the Discourse of Language, trans. Alan Sheridan (New York: Pantheon Books, 1972), 130.

17 Ibid.

${ }^{18}$ Antoinette Burton, Archive Stories: Facts, Fictions, and the Writing of History (Durham and London: Duke University Press, 2005), 6.

${ }^{19}$ Ibid., 7.

${ }^{20}$ Susan Douglas, "Writing from the Archive: Creating Your Own," in Media History and the Archive, ed. Craig Robertson (London and New York: Routledge, 2011), 9.

${ }^{21}$ Ibid., 13.
} 
that is, to trace the development of mestizaje as an idea by looking at different aspects of Mexican culture.

In his study of the relationship between identity and modernity in Latin America, sociologist Jorge Larrain observes that an ideal and complete work on identity would take into consideration all forms of culture, ranging from the theoretical, scientific and artistic to more popular customs, modes of entertainment and ways of life. ${ }^{22}$ But of course, a single work cannot be as comprehensive because of the limited space available in a book, the fact that the author may lack the necessary expertise in a particular field and so on. It is thus inevitable for the author to make choices and to privilege that which she/he considers to be the most representative areas. Questions of race, identity and modernity in Latin American have been addressed through varied lens, such as science, ${ }^{23}$ education, ${ }^{24}$ literature, ${ }^{25}$ cinema ${ }^{26}$ and telenovelas. ${ }^{27}$ Other works have been more interdisciplinary, such as Larrain's, which combines an analysis of the social sciences with that of literature, religion and the mass media. A further example, and one that influenced the

\footnotetext{
22 Jorge Larrain, Identity and Modernity in Latin America (Cambridge, UK: Polity Press, 2000), 9.

${ }^{23}$ Nancy L. Stepan, The Hour of Eugenics: Race, Gender, and Nation in Latin America (Ithaca, NY: Cornell University Press, 1991). Alexandra M. Stern, "From Mestizophilia to Biotypology: Racialization and Science in Mexico, 1920-1960," in Race \& Nation in Modern Latin America, ed. Nancy P. Appelbaum et al. (Chapel Hill, NC: The University of North Carolina Press, 2003), 187-210.

${ }^{24}$ Mary K. Vaughan, The State, Education, and Social Class in Mexico, 1880-1928 (DeKalb, IL: Northern Illinois University Press, 1982). Stephen Lewis and Mary K. Vaughan, The Eagle and the Virgin: Nation and Cultural Revolution in Mexico, 19201940 (Durham and London: Duke University Press, 2006).

${ }^{25}$ Doris Sommer, Foundational Fictions: The National Romances of Latin America (Berkeley and Los Angeles: University of California Press, 1991).

${ }^{26}$ Charles Ramírez Berg, Cinema of Solitude: A Critical Study of Mexican Film, $1967-$ 1983 (Austin, TX: University of Texas Press, 1992).

${ }^{27}$ Mauro Porto, "Telenovelas and Representations of National Identity in Brazil," Media, Culture and Society, 33 (2011): 53-69. Samantha Nogueira Joyce, Brazilian Telenovelas and the Myth of Racial Democracy (Lanham, MD: Lexington Books, 2012).
} 
structure of this dissertation, is the work of historian Anne Doremus, which explores the role of cinema and literature in constructing a unified notion of mexicanidad (or Mexican-ness). ${ }^{28}$ She argues that it is necessary to "study both high and low culture in order to obtain a holistic understanding of the articulations and functions of national identity."29

The archive I have assembled is interdisciplinary in the sense that it brings together different elements, such as literary, anthropological, philosophical and sociological works, as well as television programs. According to cultural historian Joe Moran, the advantage of an interdisciplinary approach is that it is "always transformative in some way, producing new forms of knowledge in its engagement with discrete disciplines. ${ }^{30}$ Moreover, this approach critiques the distinction of value between texts: how some are considered worthy of study and others are not. ${ }^{31}$ For example, literary scholar Susan Gillman notes that the genre of melodrama has generally been dismissed as having no "literary merit" because of its seemingly flat and stereotyped characters, or else, it has been separated from "serious social criticism." 32 Gillman adds that such dismissive approach then "refuses the possibility of melodrama's doing cultural work, of the melodramatic narrative's being itself' an ideological response to the social. ${ }^{33}$ Similarly, American studies scholar Robert Allen points out that telenovelas and soap

${ }^{28}$ Anne Doremus, Culture, Politics, and National Identity in Mexican Literature and Film, 1929-1952 (New York: Peter Lang Publishing, 2001).

${ }^{29}$ Ibid., 9.

${ }^{30}$ Joe Moran, Interdisciplinarity (London and New York: Routledge, 2002), 16.

${ }^{31}$ Ibid., 76.

${ }^{32}$ Susan Gillman, "The Mulatto, Tragic or Triumphant? The Nineteenth-Century American Race Melodrama," in The Culture of Sentiment: Race, Gender, and Sentimentality in $19^{\text {th }}$ Century America, ed. Shirley Samuels (New York and Oxford: Oxford University Press, 1992), 224.

${ }^{33}$ Ibid. 
operas have been largely ignored in the "serious" literature on television and have been regarded with disdain in the press despite the fact that they are the most popular form of TV fiction across the world. ${ }^{34}$ Telenovelas alone, for example, have been exported to over 100 countries and translated into 27 languages ${ }^{35}$ Moreover, as cinema has become a more expensive cultural activity for the popular classes in Mexico because of the liberalization of ticket prices and privatization of government-owned infrastructure, ${ }^{36}$ it can be argued that television (and telenovelas in particular) now reaches a wider audience and exerts a larger influence. I privilege television over films (not that the two are mutually exclusive) not only because cinema as a nation-building tool has been theorized at length, ${ }^{37}$ but to highlight the telenovela's value as a cultural text that is worth reading. As Lauren Berlant and other scholars have argued, the perceived triviality and banality of mainstream research materials require "an intensified critical engagement with what had been merely undramatically explicit;"’38 their very popularity and impact on everyday life are what make them important.

\footnotetext{
${ }^{34}$ Robert Allen, To Be Continued...Soap Operas Around the World (London and New York: Routledge, 1995).

${ }^{35}$ Francie Chassen-López, "Distorting the Picture: Gender, Ethnicity, and Desire in a Mexican Telenovela," Journal of Women's History, 20 (2008): 106-129.

${ }^{36}$ Ignacio M. Sánchez Prado, Screening Neoliberalism: Transforming Mexican Cinema, 1988-2012 (Nashville, TN: Vanderbilt University Press, 2014).

${ }^{37}$ Ramírez Berg, Cinema of Solitude. Ana M. Lopez, "Tears and Desire: Women and Melodrama in the 'Old' Mexican Cinema," in Mediating Two Worlds: Cinematic Encounters in the Americas, ed. John King et al. (London: BFI Publishing, 1993), 147163. Joanne Hershfield and David Maciel, Mexico's Cinema: A Century of Film and Filmmakers (Oxford, UK: SR Books, 1999). Doremus, Culture, Politics, and National Identity in Mexican Literature and Film, 1929-1952.

${ }^{38}$ Lauren Berlant, The Queen of America Goes to Washington City: Essays on Sex and Citizenship ( $3^{\text {rd }}$ ed.) (Durham and London: Duke University Press, 2005), 12. Michael Billig, Banal Nationalism (London: Sage Publications, 1995). Hugo Benavides, Drugs, Thugs, and Divas: Telenovelas and Narco-Dramas in Latin America (Austin, TX: University of Texas Press, 2008).
} 
The archive I was assembling around mestizaje initially only included telenovelas, as I was seeking to examine the mediated (re-) production of this ideology and its pervasive logic of blanqueamiento (whitening) through an analysis of stereotypes, casting choices, dialogue and central love plots. However, I decided to expand the archive when I realized that in order to have a more holistic understanding of mestizaje and its history, I had to immerse myself in the writings of those intellectuals who were among the first to theorize mestizaje as the basis of Mexican nationalism. According to anthropologist Ana Alonso, the focus on these Mexican intellectuals is important because they "were 'founders of discursivity' who produced 'the possibilities and the rules for the formation of other texts' key to the articulation of new postrevolutionary forms of governmentality." ${ }^{39}$ Moreover, I became interested in exploring how some of these texts, to borrow from Said, "acquire [d] mass, density, and referential power among themselves and thereafter in the culture at large." $" 40$ The inclusion of works by intellectuals was daunting at first because it took me out of my comfort zone, as I come from a media studies background, but was necessary to give my thesis added weight. It also took me to unexpected places, where I learned about the institutionalization of anthropology, education and eugenics, which I would have missed by solely focusing on television. I chose to have such seemingly disparate texts in conversation with each other in order to show that mestizaje does not exist in an "archival vacuum," across all aspects of Mexican culture. Moreover, I organized the thesis in a chronological

\footnotetext{
${ }^{39}$ Ana M. Alonso, “Territorializing the Nation and 'Integrating the Indian:' 'Mestizaje' in Mexican Official Discourses and Public Culture," in Sovereign Bodies: Citizens, Migrants, and States in the Postcolonial World, ed. Thomas Blom Hansen and Finn Stepputat (Princeton, NJ: Princeton University Press, 2005), 40.

${ }^{40}$ Said, Orientalism, 20.

${ }^{41}$ Ibid., 13.
} 
order, paying particular attention to the time periods when questions of national identity were at the forefront of public debates in Mexico in order to ensure the archive was of a manageable size.

A final point to make here is that the methodology of critical discourse analysis, which focuses on language as an instrumental part of social life, is fundamental in my approach to the texts that constitute the archive around mestizaje. According to discourse scholars, critical discourse analysis sees discourse - the way language is used in speech and in writing - "as a form of "social practice." "42 Discourse analysis is concerned with the content, form and structure of texts as much as with their social context. Because all discourses are historical, they can only be understood in relation to their context. Linguistics scholar Norman Fairclough observes that for this reason, any and all discursive analyses must always be "oriented to the social character of texts." 43 Discourse analysis is an interpretative and explanatory methodology that seeks to identify what is assumed in texts in order to make clear how texts contribute "to processes of meaningmaking." 44 Fairclough further points out that because texts have social, political and material consequences and effects, it is vital to analyze and interpret these consequences and effects in order "to raise moral and political questions about contemporary societies." 45 Similarly, Teun van Dijk and other scholars note that critical discourse analysis is a form of research primarily focused on social problems and concerned with

\footnotetext{
${ }^{42}$ Stefan Titscher et al., Methods of Text and Discourse Analysis: In Search of Meaning, trans. Bryan Jenner (London: Sage Publications, 2000), 26.

${ }^{43}$ Norman Fairclough, Analysing Discourse: Textual Analysis for Social Research (London and New York: Routledge, 2003), 5.

${ }^{44}$ Ibid., 11.

${ }^{45}$ Ibid., 14.
} 
understanding how discourses enact, legitimate, reproduce or challenge relations of power, dominance and inequality in a particular social and political context. ${ }^{46}$

Critical discourse analysis is useful for the nature of this project because it allows me to examine what kind of discursive strategies are deployed in the exercise and reproduction of power relations in Mexico. For example, in my research materials, I pay particular attention to narrative voice and style; the racialization of the language of beauty and the spatial tropes of high/low; the mitigation and euphemization of Spanish colonialism as tolerant and inclusive; the semantic reversals of blame; the representation of mestizos and indigenous peoples as civilized and primitive, respectively, in order to provide a detailed picture of how mestizaje is deployed in the service of the dominant group.

In the next section, I provide an overview of the relationship between Mexican intellectuals and the state - a relationship that has given much shape and direction to this dissertation. My engagement with the writings of Mexican intellectuals proved productive because it showed me that this social group has historically been embedded in state institutions and practices, which encouraged me to expand the archive so that I could offer a more holistic discussion of the working mechanisms of mestizaje.

Moreover, the overview below underlines that these intellectuals often worked alongside

\footnotetext{
46 Teun van Dijk, "Discourse and the Denial of Racism," Discourse \& Society (1992): 87118. Teun van Dijk, "Critical Discourse Analysis," in The Handbook of Discourse Analysis, ed. Deborah Schiffrin et al. (Malden, MA: Blackwell Publishing, 2001), 352371. Stuart Hall, "Foucault: Power, Knowledge and Discourse," in Discourse Theory and Practice: A Reader, ed. Margaret Wetherell et al. (London: Sage Publications, 2001), 198-209. Michael Billig, "Discursive, Rhetorical and Ideological Messages," in Discourse Theory and Practice: A Reader, ed. Margaret Wetherell et al. (London: Sage Publications, 2001), 210-221.
} 
each other in state institutions and referred to each other's works in their writings, thereby granting authority and referential power to mestizaje in the process.

\section{Intellectuals and the State}

In order to set the criteria for defining an intellectual, I draw from the thorough work of Miller. She identifies the characteristics common to intellectuals in Latin America as follows: they are national figures who are often based in the capital city and are of a bourgeois background; they contribute to debates on general social affairs, rather than restricting themselves to their area of expertise; they use their established authority to make "a bid for national influence"; they view themselves as keepers and interpreters of national identity; and they attempt to maintain a degree of independence from both church and state. ${ }^{47}$ However, total independence has been difficult to achieve since the state has remained the main source of status for intellectuals, in part because, at least until the 1960 s, there was no mass reading public or market for their work. ${ }^{48}$ The expansion of universities after the 1960s did provide intellectuals a wider public, but by then their influence was being undercut by the rise of the mass media. ${ }^{49}$

The Mexican state is regarded as one of the classic examples in Latin America that "coddles" its intellectuals and only rarely coerces them - not that it is opposed to doing so. ${ }^{50}$ The post-revolutionary Mexican state established a close relationship with intellectuals by providing them employment, prestigious posts and intellectual patronage (prizes, fellowships and scholarships), as well as by financing their publications (for

\footnotetext{
${ }^{47}$ Miller, In the Shadow of the State, 6

${ }^{48}$ Ibid., 44.

49 Ibid., 29.

${ }^{50}$ Ibid., 44.
} 
example, the state founded the publishing house Fondo de Cultura Económica in 1934, which prints many academic works today). ${ }^{51}$

During the Liberal period of the 1850s, intellectuals exercised a considerable degree of influence in society since they were recruited by President Benito Juárez to promote a national culture and history. On the other hand, Miller observes that the successor to Juárez, Porfirio Díaz, favored military power over intellectual influence. He marginalized many emerging middle-class intellectuals by promoting an elite group, the positivist científicos (scientists), as advisers to his administration (1876-1911) and by granting them access to public office. ${ }^{52}$ When the Mexican Revolution broke out in 1911, intellectuals remained largely apathetic to the events around them. An exception here was the sociologist Andrés Molina Enríquez, who contributed to drafting Article 27 of the 1917 Constitution, which stipulated the nationalization of Mexico's natural resources and the state's obligation to redistribute land in the form of ejidos (small parcels of communal land that could not be sold or rented). I take Molina Enríquez's long monograph, Los grandes problemas nacionales (The Great National Problems, 1908), as the first case study of the thesis. In the third chapter, I examine how Molina Enríquez influenced revolutionary thinking as much as he helped inaugurate "the golden age of mestizofilia, ${ }^{, 53}$ or the valorization of the mestizo as the embodiment of Mexican-ness.

Following the Revolution, the leaders of the newly established government recognized that intellectuals could be useful in providing legitimacy to the state both at

\footnotetext{
${ }^{51}$ Claudio Lomnitz, Deep Mexico, Silent Mexico: An Anthropology of Nationalism (Minneapolis, MN: University of Minnesota Press, 2001).

${ }^{52}$ Miller, In the Shadow of the State, 45.

53 Agustín Basave Benítez, México mestizo: Análisis del nacionalismo mexicano en torno a la mestizofilia de Andrés Molina Enríquez (Mexico: Fondo de Cultura Económica, 1992), 121.
} 
home and abroad. The president of the time, Alvaro Obregón (1920-1924), sought to win the support of the cultural elite by granting one of its leaders a "prominent role in the post-revolutionary order:" ${ }^{54}$ philosopher José Vasconcelos, who served as Dean of the National University in 1920 and as Minister of Public Education from 1921 to 1924. During his tenure at the latter institution, he launched an educational crusade that sought to integrate indigenous peoples and peasants into the nation, as well as a cultural renaissance in music, literature and the arts. Historian David Brading comments that Vasconcelos, who rallied his colleagues "to abandon [their] ivory towers and seal a pact of allegiance to the Revolution," inspired a whole generation of intellectuals to enter public service and to implement the policies of the government, ${ }^{55}$ thus helping to consolidate a model of state-run culture. For example, the Mexican Constitution of 1917 stipulated that the state was not only responsible for regulating education across the country, but also all "institutions of scientific research, fine arts, and technical instruction; museums, libraries, observatories, and other institutes for the general culture of the inhabitants of the Nation." ${ }^{56}$ Vasconcelos was, however, a rare figure because no other intellectual of the time occupied such a high-ranking post. Moreover, many of his educational reforms were undermined when he was replaced at the Ministry of Public Education in 1924, as he bitterly recounts in his memoir entitled El desastre (The Disaster; 1938, 1982). In fact, Vasconcelos' relationship with the government proved to be contentious. His efforts to establish himself as an independent politician, running for

\footnotetext{
${ }^{54}$ Miller, In the Shadow of the State, 46.

${ }^{55}$ David Brading, Prophecy and Myth in Mexican History (Cambridge, UK: Centre of Latin American Studies, University of Cambridge, 1984), 72.

${ }^{56}$ Quoted in Miller, In the Shadow of the State, 89.
} 
president in 1929, were repeatedly thwarted by the government and he was forced to go into exile.

The presence and undeniable influence of Vasconcelos in the post-revolutionary order make him an important subject of study. I dedicate the fourth chapter of this thesis to exploring how he develops the theory of mestizaje in La raza cósmica (The Cosmic Race, 1925) and other writings, paying close attention to discourse. For example, I look at how the recurrence of the language of redemption and improvement and the spatial tropes of high/low serve to (re-) produce the view that the poor and indigenous populations are inferior and thus need the guiding hand of the mestizo intellectual in order to be brought into civilization. I also explore how the language of beauty is correlated to culture, civilization and class status. Moreover, I focus on how the narrative of Latin America as a more spiritual, open and tolerant place vis-à-vis the Anglo-Saxon world is constructed and to what ends. I investigate how this narrative helps occlude issues of race and racism in Latin America. Finally, I am particularly concerned with tracing how the ideas and theories of these intellectuals travel and acquire meaning as they are interpreted in different realms of culture. For example, in the case of Vasconcelos, how did he influence the state educational policies of the 1920s and the eugenics movement of the 1930s?

The anthropologist Manuel Gamio is a key thinker who is closely associated with the official policies of indigenismo (indigenism), which championed the integration of indigenous peoples into Mexico’s modern, Spanish-speaking nation. He distinguished himself from other intellectuals because of his positive re-evaluation of indigenous cultures and their contribution to the nation, but he ultimately sought their assimilation. 
As he explains in his pivotal publication, Forjando patria (Forging a Nation, 1916), discussed in the third chapter, the bases for a coherent Mexican nationalism are: "Fusion of races, convergence and fusion of cultural characteristics, linguistic unification and economic equilibrium among social groups. ${ }^{.57}$ Gamio's anthropological and archeological endeavors lent support and prestige to the Mexican state. Miller points out that Gamio's results of his excavations at the pre-Aztec site of Teotihuacán, published in 1922 as The Population of the Teotihuacán Valley, attracted international acclaim and "incidentally enhanced the credibility of the Obregón government as a patron of scientific progress. ${ }^{.58}$ Gamio's indigenista activities also reached the popular realm since he participated as a judge in the first indigenous beauty contest in $1921 .{ }^{59}$ Prior to the event, Gamio wrote an article in a newspaper to explain to the general public how indigenous peoples could be considered beautiful and to argue that this contest was an important first step toward their cultural integration into the nation. ${ }^{60}$

Gamio's relationship with the Mexican government was not without its obstacles. For example, despite the success of the Teotihuacán excavation, Gamio found it impossible to secure state funding for similar projects in the southern state of Oaxaca. In

\footnotetext{
${ }^{57}$ Manuel Gamio, Forjando patria, ( $3^{\text {rd }}$ ed.) (Argentina: Editorial Porrúa, S.A., 1982), 183. All translations are mine unless otherwise stated.

${ }^{58}$ Miller, In the Shadow of the State, 140.

${ }^{59}$ The concept of "commodity racism," formulated by feminist scholar McClintock, can be useful here to understand how certain ideas are expanded through popular products. McClintock observes, for example, how commodity consumption in England helped "package, market and distribute evolutionary racism on a hitherto unimagined scale," transcending class boundaries and (re-) inventing "British national unity" (Imperial Eyes, 209). In Mexico, reconstructed monuments, museums, murals and popular events like the India Bonita contest helped circulate the politics of indigenismo in the culture at large, thereby naturalizing its folkloric notion of indigenousness as integral to national identity. ${ }^{60}$ Rick López, "The India Bonita Contest of 1921 and the Ethnicization of Mexican National Culture," Hispanic American Historical Review, 82 (2002): 291-328.
} 
fact, governmental support for his work ceased completely with the transition from Obregón to Plutarco Elías Calles in 1924 and did not resume until 1940, when he became director of the Inter-American Indigenous Institute. He recounts his frustrated career interests in a letter to his US mentor, Franz Boas, as such: "Since 1925...I have been working without any real enthusiasm because...I have been unable to devote myself fully to the studies of society that have given me so much satisfaction." ${ }^{\prime 61}$ The experiences of both Gamio and Vasconcelos underscore the fact that the relationship between intellectuals and the Mexican state is not one of unending coddling. The state appropriates ideas from intellectuals that suit its aims and policies, but it is not opposed to undermining them through containment in bureaucratic institutions or through force.

El perfil del hombre y la cultura en México (Profile of Man and Culture in Mexico, 1934) by philosopher Samuel Ramos and El laberinto de la soledad (The Labyrinth of Solitude, 1950) by Octavio Paz are further interesting case studies, and featured on the fifth chapter, of how ideas travel and are selectively appropriated by the state. Ramos' book, which was reprinted in 1938 and in 1951 after the first edition quickly sold out, is hailed as a classic study of mexicanidad. This status occludes the fact that this work was a critique of the state's politics of indigenismo and cultural nationalism. For example, Ramos argues that Mexican culture is "European by definition" and thus the efforts of indigenistas to create a culture free from European influence is misguided, wryly noting: "In order to turn its back on Europe, Mexico has taken refuge in nationalism... which is in itself a European idea." ${ }^{92}$ Ramos' work could

${ }^{61}$ Miller, In the Shadow of the State, 140.

${ }^{62}$ Samuel Ramos, El perfil del hombre y la cultura en México (2 ${ }^{\text {nd }}$ ed.) (Mexico: Editorial Pedro Robredo, 1938), 137. 
be incorporated into the state's vision of the nation, however, because his notion of mexicanidad was based on mestizaje. He reproduced many stereotypes rooted in mestizaje that frame indigenous peoples as being backward but redeemable. Challenging indigenistas, Ramos did make a point of downplaying the contributions of indigenous peoples to contemporary Mexican culture, describing them as passive and as "a chorus that bears silent witness to the drama of Mexican life." ${ }^{93}$ This strategy of ignoring the indigenous part of the mestizaje equation is also evident in the writings of Paz and Vasconcelos. Ramos had a somewhat negative view of racial mixing and thus attributed all the ills and defects of Mexico to the figure of the pelado, or the urban poor mestizo. Interestingly enough, the pelado was to materialize in the beloved character of Cantinflas, played by the actor Mario Moreno, who appeared in multiple films from the 1930s onward. Cultural critic Carlos Monsiváis and Doremus have argued that the festive representation of poverty, embodied in Cantinflas, served to vindicate the masses and to compensate them for their lack of economic power. ${ }^{64}$

El laberinto de la soledad suffered a similar fate to Ramos' book. While Paz framed Mexican nationalism in universal terms, observing that "our nationalism...must lead to a universal search," his work was understood to be definitive study of mexicanidad. ${ }^{65}$ This was the case because of his sweeping representation of "the Mexican" as solitary, festive, violent and so on, which helped construct a simplified and stereotypical notion of mexicanidad. Both Ramos and Paz sought to maintain a degree of

\footnotetext{
${ }^{63}$ Ibid., 85.

${ }^{64}$ Carlos Monsiváis, Mexican Postcards, trans. John Kraniauskas (London and New York: Verso, 1997). Doremus, Culture, Politics, and National Identity in Mexican Literature and Film, 1929-1952.

${ }^{65}$ Octavio Paz, El laberinto de la soledad (Mexico: Fondo de Cultura Económica, 1950), 233.
} 
critical distance from politics, but were nonetheless embedded in the state. According to Miller, Ramos became director of the National University's Faculty of Philosophy and Letters in 1945 and coordinator of the Humanities Department in 1954. Moreover, the study of Mexican identity that reached its peak from 1949 to 1952 was sponsored by the state and directed by Ramos. Paz for its part became a diplomat in 1943, worked in the Mexican Foreign Ministry for six years (1953-59) and was made ambassador to India in $1962 .{ }^{66}$

The final intellectuals I discuss in the dissertation are the historian Enrique Krauze and the anthropologists Arturo Warman, Margarita Nolasco Armas, Guillermo Bonfil Batalla, Mercedes Olivera de Vazquez and Enrique Valencia. These anthropologists were members of a group of young professors at the National School of Anthropology in Mexico City, whose 1968 manifesto, entitled De eso que llaman antropología mexicana (Of that which They Call Mexican Anthropology) and discussed in the sixth chapter, offered a sharp critique of anthropology and official indigenismo that Gamio had helped define in the 1920s. The authors of the manifesto argued that Mexican anthropology had betrayed its scientific and critical vocation by working as an agent of the state. This line of argument caused tensions in the School of Anthropology and culminated in the expulsion of Bonfil Batalla, underscoring the fact that many indigenistas remained loyal to the government. ${ }^{67}$

In his most influential book, México Profundo (Deep Mexico, 1996), Bonfil Batalla contended that two civilizations coexist in Mexico: Mesoamerican and Western, or what he respectively called, deep Mexico and imaginary Mexico. The relationship

\footnotetext{
${ }^{66}$ Miller, In the Shadow of the State, 87.

${ }^{67}$ Lomnitz, Deep Mexico, Silent Mexico, 232.
} 
between deep Mexico and imaginary Mexico has been confrontational because of the latter's exclusionary vision of the nation. In the seventh chapter, I am interested in exploring how Bonfil Batalla challenges the twin strategies of mestizaje and indigenismo throughout México Profundo. What alternatives does he propose? Moreover, what is the significance of this book's publication at a time when the question of indigenous rights and culture was central to the political agenda in Mexico? Much like his predecessors, Bonfil Batalla remained rooted in the state, becoming director of the INAH and the National Council for Culture and Arts (Conaculta). He also founded the National Museum of Popular Cultures in 1982. Krauze for his part is less embedded in the state and has developed strong ties with private enterprise, in particular with the media conglomerate of Televisa. Anthropologist Claudio Lomnitz notes that Krauze belongs to the "new cultural elite that fuses writing with business," which became prominent alongside the neoliberal policies of the 1980s and 90s. ${ }^{68}$

The high degree of co-option of intellectuals into official institutions points to what sociologist Natividad Gutiérrez calls "the all-embracing corporatism that characterizes the exercise of power in Mexico." ${ }^{69}$ Moreover, this underscores the fact that the Mexican state appointed itself 'as the 'protector' and 'administrator' of the nation's cultural heritage. ${ }^{.70}$ However, with the advent of neoliberalism, the state sought to reduce its role in the economy and in other areas, such as education, art and science, thereby paving the way for the rise of the mass media as the foremost interpreter of national

\footnotetext{
${ }^{68}$ Lomnitz, Deep Mexico, Silent Mexico, 215.

${ }^{69}$ Gutiérrez, Nationalist Myths and Ethnic Identities, 136.

${ }^{70}$ Ibid.
} 
identity. In the next section, I turn my attention to exploring the role of television in Mexico.

\section{Television and National Identity}

The development of television in Mexico is synonymous with the Azcárraga family and the Televisa Corporation. Televisa maintained a quasi-monopolistic dominance of the Mexican television market until 1993, when the Televisión Azteca network was launched. ${ }^{71}$ Despite competition from TVAzteca and the fragmentation of audiences due to the advent of cable, satellite and the Internet, Televisa's telenovelas continue to dominate across Latin America and the US Hispanic market. According to communication studies scholar Patrick Murphy, the Mexican state's adoption of neoliberal policies has strengthened Televisa's cultural role to the extent that the project of modernization in Mexico has been as much influenced "by the pleasure audiences find in the genres, dramas, and transcultural imagery conveyed by Televisa-owned media as by the discourse of progress supplied by the state. Mediations of modernization have...established Televisa as a marker of myths and purveyor of modern modes of existence."72 In other words, Televisa has taken on the role of educating the public on how to be modern and Mexican. Telenovelas in particular have become the main vehicle for narrating the nation and making sense of modernity's chaos. ${ }^{73}$ Moreover, telenovelas

\footnotetext{
${ }^{71}$ John Sinclair, Latin American Television: A Global View (New York and Oxford: Oxford University Press, 1999).

${ }^{72}$ Patrick Murphy, "Television and Cultural Politics in Mexico: Some Notes on Televisa, the State, and Transnational Culture," Howard Journal of Communication, 6 (1995): 251. ${ }^{73}$ Catherine L. Benamou, "Televisual Melodrama in an Era of Transnational Migration: Exporting the Folkloric Nation, Harvesting the Melancholic-Sublime," in Latin American Melodrama: Passion, Pathos, and Entertainment, ed. Darlene J. Sadlier (Urbana and Chicago, IL: University of Illinois Press, 2008), 139-172. Ana M. Lopez, "Our
} 
have become instrumental in providing "the narratives and images through which the 'imagined community' of the nation can become a lived experience." ${ }^{74}$ According to Latin American studies scholars William Rowe and Vivian Schelling, the only other media form to have enjoyed a similar influence and reach in Mexico has been cinema, which allowed people to see themselves - their own faces, gestures and language represented for the first time "in the new public space of the nation." $" 75$ Through film images, people could celebrate their newfound "social presence."76

Although Televisa is typically associated with telenovelas, Lomnitz observes that this conglomerate has become more involved in "high culture" in order to fill the void of the government. For example, Televisa has built a modern-art museum; it has staged high profile art exhibitions in the US; and it has established connections with one of Mexico's two main intellectual groups - these two groups are represented by the journals Nexos and Vuelta ${ }^{77}$ the latter of which has received more concessions from Televisa than the state. ${ }^{78}$ In chapter seven, I examine the relationship between Televisa and one of Vuelta's leaders, the aforementioned Krauze, through the lens of one of their collaborative efforts, the 1994 historical telenovela entitled El vuelo del águila (The Flight of the Eagle). The

Welcomed Guests: Telenovelas in Latin America," in To be Continued... Soap Operas Around the World, ed. Robert Allen (London and New York: Routledge, 1995).

${ }^{74}$ Vivian Schelling, "Popular Culture in Latin America," in Modern Latin American Culture, ed. John King (Cambridge, UK: Cambridge University Press, 2004), 186.

${ }^{75}$ William Rowe and Vivian Schelling, Memory and Modernity: Popular Culture in Latin America (London and New York: Verso, 1991), 232.

${ }^{76}$ Ibid.

${ }^{77}$ According to Miller, "in the context of a conflict-ridden university system, a weak press and a severely constrained book publishing industry, the main medium for exchange of ideas in [Latin] America has been the periodical" (In the Shadow of the State, 31). Different generations of intellectuals thus tend to be associated with a particular journal.

${ }^{78}$ Lomnitz, Deep Mexico, Silent Mexico, 298. 
release of the telenovela coincided with the wide-scale revision of government-issued schoolbooks and the history curriculum. In this chapter, I am interested in exploring what version of Mexican history Krauze and Televisa construct for the public and how does it align with the neoliberal interests of the state.

Telenovelas are melodramatic series with an episodic narrative developed in the span of six to nine months and with a definite ending that permits narrative closure. They are prime time entertainment targeted to a wide and heterogeneous audience. The main difference between telenovelas and Anglo soap operas is the former's complete narrative closure. American studies scholar Adriana Estill notes that telenovelas are "tidy" because they tie the loose ends, "clean up" any doubts viewers may have about a particular character or storyline and "reduce multiple meanings (many storylines, many possibilities) to clearly legible moral resolutions."79 Similarly, literary scholar Martín Ponti argues that the (heterosexual) love between the star couple is all that is needed to "restore the order temporarily threatened by its evil characters," as well as to achieve narrative closure. ${ }^{80}$

I situate the analysis of telenovelas within the larger scholarship that has documented the role of sentimental and romance novels in the production and consolidation of the national. ${ }^{81}$ Of particular importance is the work of literary critic

\footnotetext{
${ }^{79}$ Adriana Estill, "Closing the Telenovela's Border: Vivo por Elena's Tidy Nation," Chasqui, 29 (2000): 76.

${ }^{80}$ Martín Pontí, "Globo vs. Sistema Brasileiro de Televisao (SBT): Paradigms of Consumption and Representation on Brazilian Telenovelas," in Soap Operas and Telenovelas in the Digital Age: Global Industries and New Audiences, ed. Diana I Rios and Mari Castañeda (New York: Peter Lang Publishing, 2011), 221.

${ }^{81}$ Nancy Armstrong, Desire and the Domestic Fiction: A Political History of the Novel (New York and Oxford: Oxford University Press, 1987). Lauren Berlant, The Anatomy of National Fantasy: Hawthorne, Utopia, and Everyday Life (Chicago, IL: The University
} 
Doris Sommer, who explores how love and politics have been inextricably linked to the history of nation building in Latin America. She notes how a variety of national ideals and projects were "all ostensibly grounded in 'natural' heterosexual love and in the marriages that provided a figure for apparently nonviolent consolidation during internecine conflicts at midcentury." ${ }^{, 2}$ Romance novels were always stories of "starcrossed lovers" who represented particular races, regions or class interests and were able to overcome their differences in the service of national unity. They were thus useful in the general elite project to hegemonize the inchoate national cultures. ${ }^{83}$ The language of romance that characterized these novels further served the elite to the extent that its power and dominance could be framed as being based on mutual affection, or seduction, rather than on violent coercion.

The essential elements that make up a telenovela's melodramatic narrative are in line with those of romance novels. These elements include an appeal to emotions; chance encounters and coincidences that reduce spectators to tears $;{ }^{84}$ the focus on the family and home $;{ }^{85}$ happy endings; the Manichean vision of the world, with its moral categories of

of Chicago Press, 1991). Ann Cvetkovich, Mixed Feelings: Feminism, Mass Culture, and Victorian Sensationalism (New Brunswick, NJ: Rutgers University Press, 1992). Gillman, "The Mulatto, Tragic or Triumphant?" Lori Merish, Sentimental Materialism: Gender, Commodity Culture, and Nineteenth-Century American Literature (Durham and London: Duke University Press, 2000).

${ }^{82}$ Sommer, Foundational Fictions, 6.

${ }^{83}$ Ibid., 5, 29.

${ }^{84}$ Steve Neale, "Melodrama and Tears," Screen, 27 (1986): 6-23. Darlene J. Sadlier, Latin American Melodrama: Passion, Pathos, and Entertainment (Urbana and Chicago, IL: University of Illinois Press, 2008). Ben Singer, Melodrama and Modernity: Early Sensational Cinema and its Contexts (New York: Columbia University Press, 2001). ${ }^{85}$ As Sadlier notes, melodramas have been traditionally "inspired by the teachings of the Catholic faith and rituals that focus on the centrality and sanctity of the family," which accounts for the predominance of family-driven plots in telenovelas (Latin American Melodrama, 10). 
absolute virtue and vice, and good and evil; and an emotional and stylistic excess in the storylines and acting. Estill points out that acting in telenovelas requires "an overwhelming exaggeration of the emotional and personal elements" and "a theatricality of reaction, not action," which involves close ups, revelation scenes and many scenes with some form of "eavesdropping" (emphasis in original). ${ }^{86}$ Moreover, Mexican telenovelas present a limited number of sets and characters that interact only with each other and seem to have no knowledge of larger social and political events, thereby creating a "closed community" [that] is complete and autonomous unto itself." 87 These closed communities can then be seen as "an extension or depiction of the ideal imagined Mexico." 98

The fact that telenovelas can have a direct impact in the social behavior of the public has been documented in the work of writer-producer-director Miguel Sabido, discussed in the sixth chapter. Sabido pioneered the education-entertainment strategy in the 1970s, when he worked as vice president for research at Televisa. Sabido argues that telenovelas can function as an effective instrument of pedagogy because of their ability to elicit emotions and a strong identification with characters, to mediate between good and evil, and to inspire talk or gossip among viewers. ${ }^{89}$ The seven telenovelas he produced for Televisa were intended to promote social messages, such as the importance of adult literacy and family planning. For example, Ven conmigo (Come with Me) motivated almost one million viewers to enroll in literacy classes and Acompáñame (Come Along

\footnotetext{
${ }^{86}$ Estill, "Closing the Telenovela's Border," 78-79.

${ }^{87}$ Ibid., 75-76.

88 Ibid., 76.

${ }^{89}$ Miguel Sabido, "The Origins of Entertainment-Education," in EntertainmentEducation and Social Change, ed. Arvind Singhal et al. (Mahwah, NJ: Lawrence Erlbaum Associates, 2004).
} 
with Me), which featured various methods of family planning, led to a 23 percent increase in contraceptive sales and to a decrease in the overall population growth rate in Mexico.

While the education-entertainment strategy may not carry much force today, telenovelas continue to be the most consumed media product in Mexico. Their popularity, ubiquity and status as a cultural and moral guide make telenovelas an important object of research. What I want to emphasize here is that the more problematic aspects of telenovelas require as much attention as the positive and educational ones. For example, what is the significance of having whiteness ${ }^{90}$ predominate in the narratives? How is whiteness reproduced as the beauty ideal through casting and stereotypes? Why are darker-skinned actors constantly relegated to the background of the white main stage, playing the minor roles of nannies, cooks and chauffeurs? How does the transformation of the female protagonist from poor to rich works as a form of cultural improvement or whitening? How does the repetition of the common rags-to-riches narrative serve to position Mexico as a modern land of opportunity where upward mobility is possible?

Although a legitimate option in itself, the use of textual analysis in this project is limited in that I do not have access to first-hand knowledge of how viewers receive, interpret and feel the images to which they are exposed on a daily basis. However, the study of representation in telenovelas is a valid method because it can provide a window into how ideas and attitudes toward race, class and sexuality are socially constructed and

\footnotetext{
${ }^{90}$ Whiteness here is understood in both physical and cultural terms. It is not only fair skin and European phenotypes that matter, but how characters come to embody "white" qualities, such as honor, beauty, respectability, civilization, modernity and sophistication, which "starkly reflects the cultural achievement of whiteness" (Anoop Nayak, "Critical Whiteness Studies," Sociology Compass, 27 [2007]: 741).
} 
maintained. The politics of representation can allow us to understand how images and ideologies have functioned in tandem with media and culture to reproduce social domination. As cultural studies scholar Stuart Hall argues, the study of representation is important because there is "power in representation: the power to mark, assign and classify." ${ }^{91}$ He further notes that power is not only about economic exploitation or physical subjugation, but must be understood "in broader cultural or symbolic terms, including the power to represent someone or something in a certain way - within a certain "regime of representation." "92 This regime of representation for its part works to maintain and naturalize interlocking systems of oppression. Moreover, sociologist Ben Carrington observes that "attention to representation allows us to map dominant ideologies as they circulate through culture and reproduce themselves as sites for the interpellation of individuals into specific gendered, classed, and racialised subjectivities." 93 Similarly, film studies scholars Richard Dyer and Robert Stam and Ella Shohat have noted that the media are central to any discussion of reality and political struggles because they all "necessarily pass through the simulacral realm of a mass culture." 94 In other words, the study of representation is one of the primary means by which we can gain any knowledge of reality.

\footnotetext{
${ }^{91}$ Stuart Hall, "The Spectacle of the 'Other,"' in Discourse Theory and Practice: A Reader, ed. Margaret Wetherell et al. (London: Sage Publications, 2001), 338.

${ }^{92}$ Hall, Representation: Cultural Representations and Signifying Practices (London: Sage Publications, 1997), 259.

${ }^{93}$ Ben Carrington, "'Race,' Representation and the Sporting Body” (paper presented for the Centre for Urban and Community Research Series, 2002). Accessed May 30, 2015, https://www.gold.ac.uk/media/documents-by-section/departments/research-centres-andunits/research-centres/centre-for-urban-and-comm/carrington.pdf.

${ }^{94}$ Richard Dyer, White (London and New York: Routledge, 1997). Ella Shohat and Robert Stam, Unthinking Eurocentrism: Multiculturalism and the Media (New York and London: Routledge, 1994), 6.
} 
In the sixth and seventh chapters, I also dedicate space to discussing Televisa as an institution and its relation to the state. To do this, I borrow from political economists who underscore "the fact that the production and distribution of culture takes place within a specific economic and political system." ${ }^{95}$ Political economy can contribute to textual analysis because it highlights that the system of production (market or state oriented) is important in establishing "generic codes, formulaic conventions, and well-defined ideological boundaries," and thus "in determining what sort of cultural artifacts are produced and how they are consumed." 96 Finally, I supplement my textual approach with secondary sources that investigate, through interviews and ethnography, how dark skin color and other markers of indigenousness and blackness that are absent from television can produce in people feelings of shame and pain, as well as how experiences of racism tend to be understood as personal faults. ${ }^{97}$

In the final chapter, I introduce the realist series Crónica de castas (Chronicles of Caste), released in April 2014 on the Mexican public network Canal Once, to highlight alternative programming to that of Televisa. The show features an array of characters and their everyday experiences of racism and classism in Mexico City. I seek to explore how Crónica de castas, through its storylines, inverted stereotypes and casting choices, exposes mestizaje as a nationalist fiction disconnected from the Mexican reality. Moreover, how does the show utilize the caste paintings of the colonial period to shed

\footnotetext{
${ }^{95}$ Meenakshi G. Durham and Douglas M. Kellner, Media and Cultural Studies: Keyworks (Malden, MA: Blackwell Publishing, 2001), xxvi. 96 Ibid., xxvii-Xxviii.

${ }^{97}$ Mónica Moreno Figueroa, "Displaced Looks: The Lived Experience of Beauty and Racism," Feminist Theory, 14 (2013): 137-151. Christina A. Sue, "The Dynamics of Color: Mestizaje, Racism, and Blackness in Veracruz, Mexico," in Shades of Difference: Why Skin Color Matters (Palo Alto, CA: Stanford University Press, 2009), 114-128.
} 
light on contemporary forms of exclusion and discrimination in terms of race, class, gender and sexuality? What is the significance of this type of programming that names racism in a context that otherwise denies it? Does it have the potential to initiate a public debate about the impact of race and skin color on everyday living? While my research is more focused on tracing the continuities of mestizaje across time and space, I include in the final chapter an analysis of this series in order to underline the ways in which this dominant ideology has been contested.

\section{Conclusion}

This dissertation combines different genres of texts in order to tell a more complete story of how mestizaje historically developed, how it travels into the popular domain, and how it acquires strength and authority in the process. The inclusion of contemporary popular examples is important to demonstrate that mestizaje is a project that is not only alive, as sociologist Olivia Gall notes, "but it is still healthy." 98 She adds that the criticism developed against mestizaje by academia and social movements is still young. I situate my thesis within this emerging scholarship that names and problematizes mestizaje in order to challenge it. Of course, the texts I have chosen are limited and do not provide the complete history of as rich a discourse as mestizaje. All I have done is to tell a part of a story and, to borrow the eloquent words of Said, "to suggest the existence of a larger whole, detailed, interesting, dotted with fascinating figures, texts, and events." 99

\footnotetext{
${ }^{98}$ Gall, "Mexican Long-Living Mestizophilia Versus a Democracy Open to Diversity," 296.

${ }^{99}$ Said, Orientalism, 24.
} 
In a previous section, I mentioned that the study of mestizaje in the Mexican national context meant for me staying close to "home." However, I did not come to an understanding of this idea until I left home to attend university in the US, and later the UK, and was exposed to postcolonial studies, feminist studies, critical race and ethnic studies, and Latin American studies. As an individual who was socialized into the same schoolbooks, texts and telenovelas that I have described, a level of detachment from home was necessary to become aware of the histories that have been obscured by official nationalism. As feminist scholar bell hooks observes, the meaning of home often changes with experiences of "decolonization [and] radicalization." ${ }^{100}$ She continues, "At times, home is nowhere. At times, one knows only extreme estrangement and alienation. Then home is no longer just one place. It is locations. Home is that place which enables and promotes varied and everchanging perspectives, a place where one discovers new ways of seeing reality, frontiers of difference." ${ }^{101}$ I can only imagine how my project might have looked different in the absence of these experiences of travel to the US and the UK, which equipped me with the critical tools necessary to make the familiar strange. According to Lata Mani and other feminist scholars, if knowledge is to be situated or engaged, "it must take account of the worlds in which it speaks." ${ }^{102}$ In other words, part of the feminist struggle is to be able to name our location(s) and to recognize our

${ }^{100}$ bell hooks, Yearning: Race, Gender, and Cultural Politics (Boston, MA: South End Press, 1990), 205.

${ }^{101}$ Ibid.

${ }^{102}$ Lata Mani, "Multiple Mediations: Feminist Scholarship in the Age of Multinational Reception," Feminist Review, 35 (1990): 38. Joan Borsa, "Towards a Politics of Location: Rethinking Marginality," Canadian Woman Studies/Les Cahiers de la Femme, 11 (1990): 36-39. Donna Haraway, "Situated Knowledges: The Science Question in Feminism and the Privilege of Partial Perspective," Feminist Studies, 14 (1988): 575-599. Caren Kaplan, Questions of Travel: Postmodern Discourses of Displacement (Durham and London: Duke University Press, 1996). 
positioning in these spaces so that we can become accountable for what and how we learn to see. I view this dissertation as a process of recovering histories as much as a personal experience of learning to see in new and different ways.

The personal investment in this study also derives from the experience of having been raised in the border city of Tijuana, which is geographically and culturally removed from the capital - the center of intellectual life and of media production. Tijuana occupies a unique place in the cultural imaginary of both the US and Mexico. For the former, Tijuana is often equated with sin, violence, corruption and lawlessness; it is a space where US citizens can engage in all sorts of illicit activities forbidden in their country. For central Mexico, Tijuana is a sort of no-man's land that sits on the periphery of authentic mexicanidad at the same time that its geographic proximity to the US makes it a repository of cosmopolitanism and cool. While Tijuana may not be the romanticized laboratory of postmodernity that the anthropologist Néstor García Canclini once envisioned, ${ }^{103}$ it is a place where the fragmented and fluid nature of identity is deeply felt. Tijuana, characterized by movement and migration, is a city where the coherence of the dominant discourses on national identity is rendered insignificant. The study of mestizaje is in some ways an attempt "to inventory the traces upon me," 104 the border subject, always perceived as not being Mexican or American enough. My positioning on the border has produced in me feelings of disconnection from and frustration by the uniform and reductive character of the notion of mexicanidad that the capital packages and

${ }^{103}$ Fiamma Montezemolo, “(Conversation with) Néstor García Canclini, on how Tijuana Ceased to Be the Laboratory of Postmodernity," in Tijuana Dreaming: Life and Art at the Global Border, ed. Josh Kun and Fiamma Montezemolo (Durham and London: Duke University Press, 2012), 94-116.

${ }^{104}$ Said, Orientalism, 25. 
distributes. These feelings and the ongoing experience of being "in-between" - having straddled two nationalities, two cultures and two languages since I was young - in many ways have motivated me to question the myth of a single and unified national identity in order to expand our understanding of what it means to be, act and feel Mexican. 


\section{Chapter Two}

\section{Race and Nation in Mexico}

In Mexico, racial and ethnic identities have gained increasing visibility in the past three decades despite the historical denial of race as a crucial factor in shaping social relations. Indigenous peoples and Afro-descendants have organized and mobilized to demand a variety of reforms to land rights, political and economic rights, and cultural autonomy. In 1992, the Mexican government amended the Constitution to recognize indigenous peoples as a minority entitled to special rights. It would then take the government over two decades to launch a census count of the country's black population. A national survey in 2015 found there are approximately 1.4 million citizens who selfidentity as Afro-Mexican, Afro-descendant or Afro-mestizo. ${ }^{105}$ However, the black population has yet to be recognized as an official minority in the Mexican Constitution. According to race studies scholars, black people have not been as successful as indigenous populations in claiming collective rights because they are perceived to be without ethnicity, or as not having a distinct culture and language from the dominant population. ${ }^{106}$ Moreover, unlike indigenous groups, black people have been entirely rendered invisible in the national narrative of mestizaje, which makes their inclusion into

\footnotetext{
${ }^{105}$ Rafa Fernandez de Castro, "Mexico 'Discovers' 1.4 million Black Mexicans - They Just Had to Ask," Fusion, December 15, 2015, accessed September 15, 2016, http://fusion.net/story/245192/mexico-discovers-1-4-million-black-mexicans-they-justhad-to-ask/. 106 Juliet Hooker, "Indigenous Inclusion/Black Exclusion: Race, Ethnicity and Multicultural Citizenship in Latin America," Journal of Latin American Studies, 37 (2005): 1-26. Bobby Vaughn, "The African Diaspora Through Ojos Mexicanos: Blackness and Mexicanidad in Southern Mexico," The Review of Black Political Economy, (2005): 49-57. Jean-Philibert Mobwa Mobwa N'Djoli, “The Need to Recognize Afro-Mexicans as an Ethnic Group," in Black Mexico: Race and Society from Colonial to Modern Times, ed. Matthew Restall and Ben Vinson III (Albuquerque, NM: University of New Mexico Press, 2009).
} 
the imagined community of the Mexican nation more ambiguous. ${ }^{107}$ The recent experiences of musician Chogo "El Bandeño" and other black Mexican citizens, who have been detained under the suspicion of being undocumented immigrants by the mere fact of their blackness, ${ }^{108}$ underscores that blackness in Mexico continues to be viewed as foreign and as antithetical to being Mexican.

Rather than simply describe the current situation in Mexico, my objective in this chapter and the thesis in general is to provide a critical analysis of the debates concerning the significance of race in the construction of the Mexican nation as they have played out across time and culture. To do this, I borrow from the works of historians, anthropologists, sociologists and other scholars who have taken a historical approach to theoretical perspectives on race, ethnicity, sex and nation in Latin America. As social anthropologist Peter Wade explains: "On a practical level, I think that current perspectives are much easier to grasp when you know where they are coming from and what they are supposed to supersede. More theoretically, I strongly believe that knowledge is a process that has its own past - an archeology or genealogy - which it is necessary to know in order to understand its current dynamic." 109 The metaphor of archeology is apt because it suggests that a study of the past can help us understand the present.

${ }^{107}$ Hooker, "Indigenous Inclusion/Black Exclusion," 17.

${ }^{108}$ Arlene Gregorious, "The Black People from Mexico Who Have Been Erased from History," April 11, 2016, accessed September 15, 2016, http://www.bbc.com/mundo/noticias/2016/04/160410_cultura_mexico_comunidad_negra discriminacion_wbm.

${ }^{109}$ Peter Wade, Race and Ethnicity in Latin America (2 ${ }^{\text {nd }}$ ed.) (London: Pluto Press, 2010), 1. 
Before exploring how race and nation become entangled in the Mexican context, it is useful to review the central concepts of race and nation. Sociologists Floya Anthias and Nira Yuval-Davis define race as one way by which boundaries are "constructed between those who can and those who cannot belong to a particular construction of a collectivity or population." ${ }^{110}$ Race delineates boundaries on the basis of immutable biological or physiognomic differences, which can be "expressed mainly in culture or life-style but is always grounded on the separation of human populations by some notion of stock or collective heredity of traits." ${ }^{111}$ Biology and culture then become entwined in the notion of race. Social theorist Paul Gilroy similarly notes that race tends to be defined in terms of culture and identity, but always involves a discourse of naturalization. ${ }^{112}$ Philosopher Walter Mignolo further points out that race is not merely a question of skin color, biology or blood, "but of categorizing individuals according to their level of similarity/proximity to an assumed model of ideal humanity." 113 As discussed below, whiteness has come to represent this ideal model of the human. Whiteness has derived much of its power from its ability to claim to speak for humanity. Moreover, sociologist Luis Martínez Andrade observes that the concept of race emerged with modernity itself and became intertwined with basic ideas about morality. In the modern period, which brought about colonization and the expansion of European empires, the idea of race could be deployed to categorize entire groups of people as non-rational, sub-human or

\footnotetext{
${ }^{110}$ Floya Anthias and Nira Yuval-Davis, Racialized Boundaries: Race, Nation, Gender, Colour and Class and the Anti-Racist Struggle (London and New York: Routledge, 1992), 2.

111 Ibid.

${ }^{112}$ Paul Gilroy, There Ain't No Black in the Union Jack: The Cultural Politics of Race and Nation (Chicago, IL: The University of Chicago Press, 1987), 42.

${ }^{113}$ Walter D. Mignolo, The Idea of Latin America (Malden, MA: Blackwell Publishing, 2005), 16.
} 
aesthetically inferior and thus as fit for slavery. In short, race at this time became "the centrepiece of social and cultural relations founded upon biological differences." 114 The creation of racial categories allowed Europeans to classify non-Europeans and to legitimize "the practices of social domination, control and socio-ethnic exploitation.".115 As Wade comments, the study of race is tied to this specific history of the world and cannot be understood without it. ${ }^{116}$

The subject of what constitutes a nation and the extent to which it is a modern or even Western phenomenon has been widely debated. Anthias and Yuval-Davis and sociologist Anthony Smith note that there are four main approaches to the notion of nation. ${ }^{117}$ The "primordialists," for example, claim that nations are natural and universal and are rooted in relationships of kinship. The "perennialists" are those who hold that nations have existed throughout history, but are not part of the natural order. The "modernists" for their part view the nation as a product of the processes of modernization and capitalism in particular. Modernist theorists such as Eric Hobsbawn and Ernest Gellner view nationalism as emerging in Europe and not earlier than in the eighteenth century. Benedict Anderson follows a similar approach, except that he locates the development of nationalism in Spanish America. Marxists have also developed their own theories of nationalism, but all share the modernist viewpoint of the nation as a social product rather than a natural one. Finally, Smith points out that the "ethno-symbolists" emerged as a reaction against the modernists who failed to accord any weight to "the

\footnotetext{
${ }^{114}$ Luis Martínez Andrade, Religion Without Redemption: Social Contradictions and Awakened Dreams in Latin America (London: Pluto Press, 2015), 8.

115 Ibid.

${ }^{116}$ Wade, Race and Sex in Latin America.

${ }^{117}$ Anthias and Yuval-Davis, Racialized Boundaries. Anthony D. Smith, Myths and Memories of the Nation (New York and Oxford: Oxford University Press, 1999).
} 
myths, memories, traditions, and symbols" of pre-modern ethnic cultures, which "give nationalism its power."118 The approach I find most useful is Anderson's notion of the nation as an imagined community and I address it in more detail below, as well as its critiques. In the next section, I provide an overview of the relation between race, nation and nationalism. I then provide a detailed discussion on how race and nation are articulated together in the ideology of mestizaje.

\section{Imagining the Nation}

In his now classic study of nationalism, Anderson defines the nation as an "imagined political community." 119 First, the nation is imagined because while most people will never meet or know of each other, they share an "image of their communion." ${ }^{\prime 20}$ The emergence of print capitalism, in particular newspapers and novels, made this imagining possible by spreading and mass reproducing information of shared events and activities, thereby creating a sense of familiar ties among individuals and of belonging to one place. Second, the nation is a community because it is conceived as a fraternal and "horizontal comradeship" for which people are willing to die. ${ }^{121}$ However, anthropologist Claudio Lomnitz observes that nationalism also involves "discourses of fraternity with hierarchical relationships." 122 In other words, nationalism "systematically distinguishes full citizens from part citizens or strong citizens from weak ones" so that

\footnotetext{
118 Ibid., 9.

${ }^{119}$ Benedict Anderson, Imagined Communities ( $3^{\text {rd }}$ ed.) (London and New York: Verso, 2006), 6 .

120 Ibid.

121 Ibid., 7.

${ }^{122}$ Claudio Lomnitz, Exits from the Labyrinth: Culture and Ideology in the Mexican National Space (Berkeley and Los Angeles: University of California Press, 1992), 11.
} 
the "bonds of dependence" are as critical as those of fraternity (emphasis in original). ${ }^{123}$ Comradeship exists among full citizens who are potential mediators between the state and those deemed dependent. ${ }^{124}$ Lomnitz's critique is useful for understanding how women and indigenous peoples are positioned as being dependent on the mestizo in the works of Mexican intellectuals analyzed throughout this dissertation.

The bonds of fraternity and dependence are, for example, evident in Latin American early romance novels. Latin American studies scholars Sarah Radcliffe and Sallie Westwood note that these novels "were explicitly expected to fill the 'gaps' in national histories, creating imaginary linkages across regional, economic and ethnic lines." 125 The popular novels of manners (or costumbrismo) offered to people of different social classes "the possibility of mutual comprehension...even it did not make them into a horizontal community of equals." ${ }^{126}$ Similarly, literary critic Doris Sommer argues that romance novels emerged in Latin America after the independence movements as an efficient medium through which the elite could reach the masses with its many projects of national consolidation. Through such literature, the elite could not only educate people about their history, customs and identity, but could promote an ideal vision of the nation. Romance novels were ultimately part of the general bourgeois project to contain differences (racial, regional, economic and otherwise) and to "hegemonize a culture in

\footnotetext{
123 Ibid., 12.

124 Ibid., 13.

${ }^{125}$ Sarah Radcliffe and Sallie Westwood, Remaking the Nation: Place, Identity and Politics in Latin America (London and New York: Routledge, 1996), 11.

${ }^{126}$ Ibid.
} 
formation" - a culture that would make "a place for everyone, as long as everyone knew his or her place." $" 127$

In his formulation of nations as imagined communities, Anderson explains that people are willing to die for the nation because it "inspires self-sacrificing love." ${ }^{128}$ This love comes from the belief that one is "naturally tied" to the nation. ${ }^{129}$ Because the nation is not chosen, much like the family, it is conceived as disinterested and it can thus ask for sacrifices. ${ }^{130}$ Anderson points out that this form of love is often evinced in the language of home or of kinship. While the term "kinship" may seem innocent of power, anthropologist Johannes Fabian argues that it is "fraught with temporal connotations."131 Referring to primordial ties and origins, "views of kinship relations can easily serve to measure degrees of advancement or modernization." ${ }^{132}$ For example, in the eighteenth century, the Spanish word for nation (nación) vacillated between a definition around a unified but ambiguous territory and a definition around lines of descent. Lomnitz notes that this identification with descent made the notion of nation "into a synonym of blood or caste and thereby provide[d] a rationale for internal divisions within colonial societies" (emphasis in original) ${ }^{133}$ The term "nación" also worked to pit peninsulares (Spaniards born in Spain) and criollos (Spaniards born in the Americas, or creoles) against each other.

${ }^{127}$ Sommer, Foundational Fictions, 29.

${ }^{128}$ Anderson, Imagined Communities, 141.

${ }^{129}$ Ibid., 143.

${ }^{130}$ Ibid., 144.

131 Johannes Fabian, Time and the Other: How Anthropology Makes its Object ( $2^{\text {nd }}$ ed.) (New York: Columbia University Press, 2002), 75.

${ }^{132}$ Ibid.

${ }^{133}$ Lomnitz, Deep Mexico, Silent Mexico, 8. 
Anderson characterizes the independence movements across Latin America, led by a small creole minority, as the first display of nationalism in the region. He argues that a sense of community emerged among creoles from their shared experiences of subordination to the Spanish crown and exclusion from political posts of official importance. ${ }^{134}$ Creoles were considered to be inferior to peninsulares by virtue of having been born in the Americas. Recall here that scientific racism and other dominant racial theories of the time posited the tropical climate and environment of Latin America as being detrimental to culture and character. Peninsulares could claim that creoles could never be true Spaniards because they were by nature different, thereby justifying their subordinate status. The creoles' shared sense of resentment against the Spanish crown began to develop into "revolutionary impulses."135

While creoles did lead the independence movements of the nineteenth century, scholars have argued that this is of small influence in the development of twentiethcentury national identities. Hobsbawm notes that the fact that a creole minority had created a limited and exclusionary idea of nation "should not be confused with nationalism which possess or develops a mass basis among the people in the form of national consciousness... although there may be historical links between the two." 136 Similarly, Miller observes that creole nationalism was elitist in that it lacked a popular base and was founded on identification with other European countries, such as France. Creole intellectuals, for example, argued that indigenous peoples living in the same territory should be regarded as members of "a nation parallel to the Spanish-Creole

${ }^{134}$ Anderson, Imagined Communities, 57.

135 Ibid.

${ }^{136}$ Quoted in Miller, In the Shadow of the State, 33. 
one."137 Mary Louise Pratt and other scholars also observe that creoles supported the independence movements mainly as a way to secure their class privileges. ${ }^{138}$ The creole project involved founding a liberal, independent and decolonized American society, which retained the basic unequal socioeconomic structures, European values and white supremacy at the same time that it "reconfirmed white male dominance, catalyzed Eurocapitalist penetration, and often intensified exploitation." ${ }^{139}$ Creole intellectuals of this period shared a sense of despair about their racial mixture and viewed it as a curse that could harm their nation's future. South America's leading intellectual, Simón Bolívar, for example, lamented: "We are the vile offspring of the predatory Spaniard who came to America to bleed her white and to breed with his victims... With such racial mixture and such a moral record can we afford to place laws above leaders and principles above men?" 140 For Bolívar, race mixture signified a state of immorality and illegitimacy that could compromise Latin America's development.

However, scholars also note that simply because the wars of independence cannot be considered nationalist movements, it does not mean that the concept of nation was irrelevant in the nineteenth century. Miller, for example, points out that the word "nación" began to gain currency among creole elites because it could help them

\footnotetext{
137 Ibid.,137.

${ }^{138}$ Mary L. Pratt, Imperial Eyes: Travel Writing and Transculturation $\left(2^{\text {nd }}\right.$ ed.) (London and New York: Routledge, 2008). Alastair Bonnett, "A White World? Whiteness and the Meaning of Modernity in Latin America and Japan," in Working Through Whiteness: International Perspectives, ed. Cynthia Levine-Rasky (New York: State University New York Press, 2002), 69-105. Vivian Schelling, Through the Kaleidoscope: The Experience of Modernity in Latin America (London and New York: Verso, 2000).

${ }^{139}$ Pratt, Imperial Eyes, 185.

${ }^{140}$ Ibid.
} 
legitimate their "claim to control the central state." ${ }^{141}$ In order to mobilize support for this, they needed to extend the benefits of republican citizenship to the broader population. ${ }^{142}$ In her survey of the emergence of peasant nationalism in Mexico and Peru, historian Florencia Mallon observes that nationalism has never been a monolithic project entirely led by the elites (as Anderson suggested). Nationalism, she explains, became "a series of competing discourses in constant formation and negotiation, bounded by particular regional histories of power relations." ${ }^{143}$ In other words, all sectors of society have participated in nation-building projects - at times negotiating, compromising or resisting these projects. However, to maintain this dissertation to a manageable dimension, I focus on the twentieth century. According to Miller, it was not until the early twentieth century that intellectuals began to promote "popular national identities on the basis of the resurrected idea that the people were a distinctively 'mixed species' and should be celebrated as such, even if only rhetorically." ${ }^{144}$ The focus of my analysis is thus the emergence of mestizaje as the basis of Mexican nationalism from the twentieth century onward.

A final aspect to discuss here is that in Anderson's theory, racism and nationalism are not explicitly connected because the nation is imagined through print languages rather than notions of blood or biological differences. Hence, anyone can become part of the nation if they learn the appropriate language. Racism for its part "dreams of eternal contaminations" and is often manifested within, rather than across, national

\footnotetext{
${ }^{141}$ Miller, "The Historiography of Nationalism and National Identity in Latin America," Nations and Nationalism, 12 (2006): 206.

142 Ibid.

${ }^{143}$ Mallon, Peasant and Nation: The Making of Postcolonial Mexico and Peru (Los Angeles and Berkeley: University of California Press, 1995), 4.

${ }^{144}$ Miller, In the Shadow of the State, 137.
} 
boundaries. ${ }^{145}$ However, the discourses of race and nation are never far apart. As philosopher Etienne Balibar notes, "racism is constantly emerging out of nationalism, not only towards the exterior but towards the interior." ${ }^{, 146} \mathrm{He}$ cites as examples the United States and France. The former instituted systemic segregation at home at the same time that it entered into the world imperialist competition and the latter developed the ideology of the "French race" at the time that its colonial enterprise was expanding. Similarly, sociologist Kathryn Manzo remarks that two of nationalism's dominant conceptual partners are race and alien, "for without the racialized kind of alien there can be no national kin. Nation and alien are relational terms, interdependent and inseparable in nationalist thought and practice." ${ }^{" 147}$ In other words, the nation needs the figure of the alien to define the legitimate citizen and establish borders. Moreover, Gilroy observes that the politics of race are "fired by conceptions of national belonging and homogeneity which not only blur the distinction between 'race' and nation, but rely on that very ambiguity for their effect." ${ }^{\text {48 }}$ The notion of nation is racialized in its representation as "simultaneously biological and cultural," 149 which serves to specify who may belong to the national community and who may not.

When discussing the development of the ideology of mestizaje, which purports to be all-inclusive, it is important to keep in mind that while in theory anyone can adopt the

145 Anderson, Imagined Communities, 149-150.

${ }^{146}$ Etienne Balibar, "Racism and Nationalism," in Race, Nation, Class: Ambiguous Identities, ed. Etienne Balibar and Immanuel Wallerstein, trans. Chris Turner (London and New York: Verso, 1988), 53.

${ }^{147}$ Kathryn A. Manzo, Creating Boundaries: The Politics of Race and Nation (Boulder, CO: Lynne Rienner Publishers, 1998), 3.

${ }^{148}$ Gilroy, There Ain't No Black in the Union Jack, 44.

${ }^{149}$ Ibid., 45. 
dominant way of life and language to be " invited into "the imagined community," 150 race and racism have been implicated in the workings of Mexican nationalism. The Spaniards' preoccupation with descent and purity of blood (the legacy of its contact with northern Africa) is but one example of how race has functioned in the Americas to determine the bonds of exclusion and inclusion.

\section{Mestizaje and Whiteness}

The term "mestizo/a" emerged during the Spanish and Portuguese colonial rule in Latin America, and was used to describe the (oft-illegitimate) offspring of Europeans and indigenous peoples. Mestizo/a was a racial category that placed hybrids or mixed-blood individuals within the racialized caste system devised and imposed by the colonizers. ${ }^{151}$ However, the mestizo/a complicated the classification of the castas (castes) because it was never an entirely fixed or immutable category. As Lomnitz demonstrates in the Mexican context, mestizo/a and indigenous identities could be transcended and whiteness (or proximity to whiteness) achieved in a few generations through marriage strategies, adoption of Spanish culture (religion, language, customs) and the right resources. Whiteness in Mexican society "represented a kind of purity because it was the only position in which wealth, status and power could be in equilibrium."152 Ethnic manipulation and the struggle for whiteness thus characterized colonial Mexico.

The Independence movement of 1810, which brought about the abolition of slavery and other forms of legal discrimination, transformed Mexico into a class society. This newfound class society reduced the complex racial dynamics of the colonial era into

${ }^{150}$ Anderson, Imagined Communities, 145.

${ }^{151}$ María L. Amado, “The New 'Mestiza,' the Old Mestizos: Contrasting Discourses on Mestizaje," Sociological Inquiry, 82 (2012): 446-459.

${ }^{152}$ Lomnitz, Exits from the Labyrinth, 274. 
a binary model, with white and indigenous peoples as polar opposites and mestizos/as as an intermediate class, ignoring the presence of Africans and other immigrants. However, this class society retained aspects of the colonial racial system, in particular the positive valorization of whiteness. For example, the ideas that "whiteness was still the only position where wealth and high status were in homeostasis" and that whiteness was an attainable status to which people could aspire remained intact. ${ }^{153}$ Class distinctions were understood and framed in racial terms so that wealthy mestizos could pass as white, and indigenous peoples and poor mestizos (particularly peasants) were associated with material poverty, ignorance, backwardness and a resistance to fully enter into "a capitalist economy of wage labor, private property and free enterprise." ${ }^{154}$ The Mexican elite and foreign employers of the time invoked the myth of the "lazy native" to explain such resistance and to justify their violent methods of control. ${ }^{155}$ Indigenousness was seen as a condition to overcome in order to achieve progress and modernity. At the turn of the nineteenth century, Mexico had failed to deliver on its promise of democracy and equality for all its citizens, and remained concentrated in the hands of the few - the privileged wealthy Mexicans of European descent - which the Revolution sought to change.

The notion of mestizaje developed in full-force during the Mexican Revolution of 1910 as a reaction against the overtly racist ideology of the Porfiriato ${ }^{156}$ what Gonzalo Aguirre Beltrán calls "rightist Westernism" for placing excessive value on European and

\footnotetext{
${ }^{153}$ Ibid., 275.

${ }^{154}$ Ibid., 276.

${ }^{155}$ Knight, "Racism, Revolution, and Indigenismo," 79.

${ }^{156}$ The Porfiriato refers to the time frame from 1876 to 1911 when Porfirio Díaz ruled Mexico.
} 
Anglo-Saxon culture. ${ }^{157}$ Policymakers of the Porfirian era were strongly influenced by social Darwinism and were convinced of the superiority of the white European to the extent that they sought to attract European immigrants to Mexico (see fourth chapter). Hence, mestizaje emerged to allow revolutionary rhetoric to distance itself from the reactionary, racist past. The Revolution brought about a newfound sense of nationalism and a new batch of intellectuals who celebrated the process of racial and cultural mixture for giving rise to the mestizo, who was neither indigenous nor European, but quintessentially Mexican. The figure of the mestizo was extolled as the "national race" of Mexico and as the carrier of "the national culture of the future." 158 The mestizo, constructed in highly masculine terms, was depicted as a rebel, an author of uprisings and the class that best understood the grievances of indigenous peoples and as such was suited to protect them. ${ }^{159}$ The mestizo became the official protagonist of the Mexican nation and mestizaje the central ideology of the many projects of national consolidation..$^{160}$

Historian Alan Knight notes that mestizaje, as a nationalist discourse and ideology, was problematic from its inception for three main reasons. First, it was an idea imposed on indigenous peoples from the elites. The generic concept of "Indian" was conceived and deployed by the non-indigenous: in the wake of the Conquest, Spaniards defined the "Indian" in negative terms to assert their identity and superiority, and later, revolutionary thinkers imagined the "Indian" as the prime symbol of national identity to further their nation-building agenda. Second, mestizaje held the belief that the process of

157 Quoted in Knight, "Racism, Revolution, and Indigenismo," 80.

${ }^{158}$ Ibid., 85.

${ }^{159}$ Ibid., 86.

${ }^{160}$ Sommer, Foundational Fictions, 22. 
acculturation could proceed in a way that the positive aspects of indigenous culture could be preserved and the negative ones eliminated. Again, this was an imposition on indigenous peoples from the outside. It was the non-indigenous elite who decided what was worth preserving and integrating into the national culture and what was not. Third, and most important, mestizaje continued to operate within the logics of racism, retaining “'race' as an independent factor, which operated alongside distinct social and historical factors." ${ }^{161}$ In short, mestizaje reproduced many of the racist assumptions rooted in Porfirian Westernism.

A prime example of the racism embedded in post-revolutionary thinking was the eugenics movement of the 1930s, which I discuss in depth in the fourth chapter. Mexican eugenicists believed a homogenous population was fundamental for the development and progress of the nation. Mestizaje was perceived to be the solution that was to bring about this desired homogenization and the subsequent consolidation of the nation. For example, Dr. Alfredo Correa, who co-founded the Mexican Eugenics Society with physician Alfredo Saavedra, stated that "[mestizaje] is the answer because once realized, the national race will be one, a model that we have seen in other countries whose result is growth and progress in addition to collective well-being." ${ }^{162}$ Mexican eugenicists invoked the figure of the mestizo in their vision of a homogenous nation without reference to other racial groups that were perceived to be "undesirable," such as the black population concentrated in the South or the Chinese immigrants in the North. As historian Alexandra Stern notes, "this absence reflected [eugenicists'] unspoken wish that the eventual outcome of racial mixing would, over time, be the disappearance of mestizos

${ }^{161}$ Knight, "Racism, Revolution, and Indigenismo," 86-87.

${ }^{162}$ Quoted in Stern, "From Mestizophilia to Biotypology," 192. 
themselves from the national landscape and the concomitant ascendancy of whites." 163 In fact, Dr. Rafael Carrillo, a popular eugenicist, commented, "if mestizaje continues indefinitely, it will disappear over time, given that the white race, being superior, will prevail over the inferior black and Indian." 164 Such explicit comments were rare, however. The paradoxical tension endemic to mestizaje is that its preference for whiteness was often buried under the "utopian discourse of inclusion," 165 which exalted pre-colonial indigenous cultures and the mestizo as icons of mexicanidad (or authentic Mexican-ness).

The notions of race and nation are never far apart in the mestizaje ideology. For example, Mexican philosopher José Vasconcelos imagined that mestizaje would bring about a new Latin American race, or a "cosmic race." Other leading national (-ist) intellectuals, such as José Martí in Cuba, envisioned the incorporation of all members of the population as one into the national body, subsuming racial differences under national identity. Gilberto Freyre for his part argued that mestizaje in Brazil would bring about racial democracy. According to race studies scholar David Goldberg, the idea of racial democracy was attractive because it "offered the possibility of belonging and social participation," and proved to be "motivating and exasperating, seemingly possible but never quite within reach."166 Similarly, sociologist Alexandre Emboaba da Costa remarks that the burden of waiting for the arrival of a racial democracy is placed unevenly on people of color. Waiting is not simply a time of hope, but can also be experienced in

\footnotetext{
163 Ibid.

164 Ibid., 193.

165 Ibid.

${ }^{166}$ David T. Goldberg, The Threat of Race: Reflections on Racial Neoliberalism (Malden, MA: Blackwell Publishing, 2009), 236.
} 
terms of "feelings of neglect, invisibility, rightlessness, lack of self-esteem, shame and nervous anxiety, all of which one is asked or expected to endure for the sake of a cherished national belonging." 167 Those who invest in anti-racist and decolonizing forms of justice are then seen as a problem and as a disruption to the eventual arrival of the harmonious national family. ${ }^{168}$ As I demonstrate throughout this project, mestizaje is paradoxical because it recognizes racial heterogeneity without abandoning the aspiration for a whitened nation; it celebrates mixture at the same time that it advocates for cultural homogenization; and in subsuming race under the aegis of national identity, mestizaje serves to obfuscate the material realities of racial differences.

A twin strategy to the development of mestizaje in Mexico was indigenismo, discussed in more detail in the sixth chapter, which sought to resolve the so-called "Indian problem" through the assimilation and acculturation of indigenous peoples. Wade explains that the politics of indigenismo were often tied to "the question of exotic and romantic symbolism, based more on the glorification of the pre-Columbian indigenous ancestry of the nation than on respect for contemporary indigenous populations. Thus the reality was one of continued discrimination and exploitation." 169 Because the Mexican nation was generally envisioned to be "mestizo in color," indigenismo aimed to enable indigenous peoples to become mestizos and transcend their indigenousness, which was viewed as an obstacle to modernity and nationhood because of the presumed continuing loyalty to a particular community or territory, rather than the nation. Embedded in the twin strategies of indigenismo and mestizaje was the idea that being Mexican meant

${ }^{167}$ Alexandre Emboaba Da Costa, "The Un(happy) Objects of Affective Community: Mixture, Conviviality and Racial Democracy in Brazil," Cultural Studies, 20 (2016): 38. 168 Ibid.

${ }^{169}$ Wade, Race and Ethnicity in Latin America, 32. 
being or becoming mestizo. As such, sociologist Natividad Gutiérrez explains, "embracing mestizaje as a way of life signifie[d] social mobility, access to a labour market and the adoption of the Spanish language, a new set of values and the central concept of patria" (or homeland). ${ }^{170}$ In other words, embracing mestizaje was perceived to be desirable because it could lead people to the path of official Mexican citizenship.

Indigenismo was crucial to the post-revolutionary state's nationalist project, which reached its apex during the 1940s and 50s with the presidencies of Manuel Avila Camacho (1940-1946) and Miguel Alemán (1946-1952). Both presidents emphasized a capitalist model of economic development in contrast to the socialist reforms of the administration of Lázaro Cárdenas (1934-1940). Historian Anne Doremus argues that Avila Camacho and Alemán wanted to "promote the image of Mexico as a modern, mestizo nation rather than an indigenous one which, to many, connoted backwardness and underdevelopment. They continued to encourage pride in Mexico's indigenous past, but emphasized mestizaje as key to the nation's social and economic welfare." ${ }^{171}$ Moreover, the ultimate goal of the Institutional Revolutionary Party (PRI), whose "sacred principle" had been the "protection of 'the Mexican," was to reach the level of progress and development of the United States and Europe. ${ }^{172}$ As such, Mexicans viewed the assimilation of "European culture and industry [as] both a right and a national past."173 Anthropologists of the time contributed greatly to the implementation of official indigenismo, particularly the anthropologist Manuel Gamio (discussed in the next

\footnotetext{
${ }^{170}$ Natividad Gutiérrez Chong, "Symbolic Violence and Sexualities in the Myth Making of Mexican National Identity," Ethnic and Racial Studies, 31 (2008): 537.

${ }^{171}$ Anne Doremus, "Indigenism, Mestizaje, and National Identity in Mexico during the 1940s and the 1950s," Mexican Studies/Estudios Mexicanos, 17 (2001): 377.

${ }^{172}$ Lomnitz, Exits from the Labyrinth, 278.

173 Ibid., 279.
} 
chapter) and Alfonso Caso. Their efforts to integrate and mesticize indigenous peoples included building roads, hospitals and schools; providing indigenous communities an education (including Spanish lessons) and access to potable water, modern agricultural and industrial techniques and equipment; and protection for their industries, particularly their artwork, which was perceived to be an important source of employment, as well as a source of national identity and pride. ${ }^{174}$ An influential contribution of these anthropologists, most of them white or light-skinned mestizos, was the redefinition of "Indian" to emphasize cultural over biological differences so that peasants of indigenous descent living in urban areas, or with no particular ties to indigenous communities, could be reclassified as mestizos. Doremus contends that this new definition benefitted the state in that it allowed for the reclassification of indigenous peoples as mestizos, making Mexico appear less indigenous and more modern. Moreover, it facilitated the process of mestizaje by reducing the need for racial mixing because indigenous peoples could become mestizos simply by adopting the dominant language, culture and ways of life. However, these anthropologists were too idealistic in thinking that Mexicans would suddenly begin considering those they previously deemed "Indians" as mestizos, when in fact, phenotype and skin color remained key factors in classification. For all its intent and purpose to understand and value indigenous peoples, indigenismo was a paternalistic, state-sponsored discourse that lacked indigenous voices and perpetuated their marginalization from society at large.

\footnotetext{
${ }^{174}$ Doremus, "Indigenism, Mestizaje, and National Identity in Mexico during the 1940s and the 1950s," 381-383.
} 
The importance of skin color ${ }^{175}$ and phenotype is embedded in the enduring and pervasive racist logic of blanqueamiento, or whitening. This whitening practice posits that racial mixing with white European or Anglo individuals is desirable because it makes populations whiter and erases seemingly inferior indigenous racial traits, leading to the "improvement" of the Mexican race. However, whitening is not just about becoming phenotypically lighter, but about becoming Christianized, urbanized and modernized. According to Goldberg, the whitening process is "seen to draw the uncivilized into civilization, the uneducated into the virtues of capitalist accumulation, the unsettled into the potential labor force, if only as a reserve army of labor." ${ }^{176}$ In short, Goldberg argues, "whitening inscribes race by deracialization. It intensifies racial dynamics, making white by de-indianizing and de-blackening..."177 Overall, whiteness derives its power by assigning race to others and remaining the unseen or unmarked category against which all other colors are measured as deviant. Race studies scholar Sara Ahmed and others have noted that the fact that whiteness has become a taken-for-granted and invisible category allows it to "get reproduced as the unmarked mark of the human." ${ }^{178}$ In other words,

${ }^{175}$ As Yuval-Davis points out, skin color "has come to be the main racist signifier, establishing the mythical races" of "white," "black" and so on. The associations of whiteness with goodness, purity and virtue, and blackness with evil, contamination and vice have served as "a legitimator of racist ideologies and practices" (Gender and Nation [London: Sage Publications, 1997], 49).

${ }^{176}$ Goldberg, The Threat of Race, 219.

177 Ibid.

178 Sara Ahmed, "Declarations of Whiteness: The Non-Performativity of Anti-Racism," Borderlands, 5 (2004). Ruth Frankenberg, White Women, Race Matters: The Social Construction of Whiteness (Minneapolis, MN: University of Minnesota Press, 1993). hooks, Yearning. Dyer, White. Nayak, "Critical Whiteness Studies." Cynthia LevineRasky, Working through Whiteness: International Perspectives (New York: State University of New York Press, 2002). Jamie Winders et al. "Making gueras: Selling White Identities on Late-Night Mexican Television," Gender, Place and Culture, 12 (2005): 71-93. 
whiteness is felt to represent the universal human condition. As such, whiteness has the power to define and inhabit the normative. It is thus crucial that whiteness is identified as a racialized position from which structural advantages are derived in order to contest its authority and dominance.

The prevalence of the notion of blanqueamiento throughout Latin America underscores the fact that mixed-race status is not an end in itself, or a status that generates pride, as the official ideology of mestizaje would have it. Instead, individuals continually struggle to lighten the skin color of future generations by choosing lighter-skinned partners in order to achieve a higher status. ${ }^{179}$ An all too common practice, for example, is for people to want to "marry up," that is, to marry a lighter person and/or someone of a higher socioeconomic status, thus underscoring the material realities of the whitening logic. As Wade observes, "mestizaje takes on powerful moral connotations: it is not just neutral mixture but hierarchical movement, and the movement that potentially has greatest value is upward movement - blanqueamiento or whitening understood in physical and cultural terms." ${ }^{, 180}$ In the name of mestizaje, whitening seeks to bleach the national body politic, thereby eliminating blackness and indigenousness from the national imaginary. White, black, brown and indigenous are not simply social identities but structural conditions that enable or restrict a person's mobility. ${ }^{181}$ The fact that whiteness continues to be correlated with wealth, power, privilege and education, and other identities are correlated with exclusion from or limited access to resources makes the struggle to "improve" the race not all that surprising.

${ }^{179}$ Sue, "The Dynamics of Color," 115.

${ }^{180}$ Quoted in Radcliffe and Westwood, Remaking the Nation, 37.

${ }^{181}$ Goldberg, The Threat of Race, 226. 
If European phenotypes predominate in Mexican television, it is because Mexico remains a European country culturally to the extent that it valorizes and upholds European standards of beauty and physical appearance, particularly whiteness. ${ }^{182}$ This is not limited to Mexico, but it is widespread among nations that share a history of colonialism. For example, Wade shows that Colombians in general seek to distance themselves from blackness, thereby legitimating the low value attached to it. ${ }^{183}$ Social anthropologist Andrew Canessa for his part notes that in Bolivia, "images of feminine physical beauty are overwhelmingly white." ${ }^{\prime 184}$ These images can be seen in advertisements, magazines, television and beauty pageants, where the winner is "invariably white." 185 Furthermore, Radcliffe and Westwood point out that the pervasiveness of "fair haired, blue-eyed and fair-skinned" women in Ecuadorean television accounts for the low self-esteem among women in indigenous communities who see themselves as ugly and worthless for failing to live up to the white beauty ideal. ${ }^{186}$ Sociologist Mónica Moreno Figueroa also demonstrates that for many Mexican women, having dark skin color is "linked with a series of emotions such as shame, pain, inadequacy, and the desire to be 'normal' and to not be 'insignificant."'187 Being white (or lighter) is correlated to being more beautiful and to having more opportunities in the workforce, education and life in general. In her comprehensive study of the politics of

${ }^{182}$ Margaret L. Hunter, "If You're Light You're Alright": Light Skin Color as Social Capital for Women of Color," Gender and Society, 16 (2002): 175-193. Hugo Nutini, "Class and Ethnicity in Mexico: Somatic and Racial Considerations," Ethnology, 36 (1997): 227-238.

${ }^{183}$ Wade, Race and Sex in Latin America, 173.

${ }^{184}$ Andrew Canessa, "Sex and the Citizen: Barbies and Beauty Queens in the Age of Evo Morales," Journal of Latin American Cultural Studies, 17 (2008): 43.

${ }^{185}$ Ibid.

${ }^{186}$ Radcliffe and Westwood, Remaking the Nation, 139.

${ }^{187}$ Moreno Figueroa, “'Linda Morenita,"” 2. 
skin tone among African-American and Mexican-American communities, sociologist Margaret Hunter similarly observes that whiteness has become normalized as the standard of beauty and femininity to which women of color are expected to aspire. ${ }^{188}$

The notion that beauty equals whiteness is not only reproduced in transnational media images but in everyday social practices as well. For example, in describing newborn babies, the words "güero/a" or "blanquito/a" (a diminutive of white) and "cute" are always entangled. The logic is that a baby is pretty if she/he looks white. Or conversely, that to be dark/black is to be ugly, which is why beauty in dark-skinned people is always qualified ("she/he may be dark, but she/he is pretty"). Anthropologist Bobby Vaughn shows in his ethnographic study of Afro-Mexicans in southern Mexico that "Afro-Mexicans commonly lament that their skin color and facial features make them ugly" to the point that the words "feo/a" (ugly) and "negro/a" (black) are almost synonymous. ${ }^{189}$ Cristina Barros also points out that individuals sometimes feel that their lighter-skinned siblings receive preferential treatment and that this causes "irreparable damage to the brown or not so white [children] of the family." ${ }^{190}$ On a more personal note - and this happens outside Mexico - when asked about my nationality and I respond that I am Mexican, I get a look of approval and I am told, “Oh, but you don't look Mexican at all.” This is rather insulting precisely because I am expected to take it as a compliment, as if all I ever wanted was to look white and I should be proud that can I pass for white. This demonstrates that to be brown/dark or to "look" Mexican is

\footnotetext{
${ }^{188}$ Hunter, Race, Gender, and the Politics of Skin Tone (London and New York: Routledge, 2005).

${ }^{189}$ Vaughn, "The African Diaspora through Ojos Mexicanos," 52.

${ }^{190}$ Quoted in James Vigil and Felipe Lopez, "Race and Ethnic Relations in Mexico," The Journal of Latino-Latin American Studies," 1 (2004): 19.
} 
somehow to be a body out of place in the modern world. Moreover, Wade contends that "the fact that mestizaje often works in zones of intimacy (sex, the family, the body) means racism lodges deep in the heart of people and society, making it difficult to both see and resist." ${ }^{191}$ In other words, mestizaje is so entrenched in Mexican history and the national imaginary that a deep-seated reluctance exists among the population to acknowledge or even discuss how race and racism continue to shape social relations in contemporary Mexico.

Mestizaje can be understood as an ideology in which processes of inclusion and exclusion coexist. According to Wade, "the opportunity for inclusion exists in the same time and space frame as the opportunity for exclusion." ${ }^{\text {"192 }}$ Appearance, culture, religion and so on can be transformed and adapted in the direction of inclusion, for example, at the same time that racialized hierarchies remain intact and point toward exclusion. ${ }^{193}$ Mestizaje is thus a site of contention. Most of the Latin American scholarship with which I engage throughout this dissertation posits that mestizaje works to essentialize difference and as such, it continues to reify race and by extension hierarchy. For instance, literary critic Antonio Cornejo Polar notes that the "concept of mestizaje falsifies the condition of [Latin American] culture."194 He explains, "what mestizaje does is to offer a harmonious image of what is obviously disjointed and confrontational, proposing representations that deep down are only relevant to those for whom it is convenient to imagine our societies

\footnotetext{
${ }^{191}$ Wade, Race and Ethnicity in Latin America, 94.

192 Ibid.

193 Ibid., 93.

194 Antonio Cornejo Polar, "Mestizaje and Hybridity: The Risks of Metaphors - Notes," in The Latin American Cultural Studies Reader, ed. Ana del Sarto et al. (Durham and London: Duke University Press, 2004), 766.
} 
as smooth and non-conflictive spaces of coexistence. ${ }^{195}$ For most Latin American scholars like Cornejo Polar, mestizaje functions as a tool of domination that helped shaped the region's nation-building projects and serves to maintain the status quo intact.

However, as Latino/a studies scholar Rubén Medina observes, it must be recognized that mestizaje has been undergoing a revision for the past three decades within a certain strand of scholarship. He notes that the theoretical debates about the concept of hybridity in general, and mestizaje in particular, have "focused on the transgressive power of hybrid identities." ${ }^{196}$ Similarly, postcolonial studies theorist Lata Mani notes that the concept of hybridity has become useful to Third World intellectuals working in the First World because it provides "the possibility of a collective politics," as it pays attention to difference, ambiguity and contradiction. ${ }^{197}$ More specifically, for Chicano/a scholars working in US academia, mestizaje has come to function as a strategic methodology of resistance. ${ }^{198}$ Many scholars rightly point out that mestizaje should not be dismissed because it can be used as a critical conceptual category "for understanding

\footnotetext{
195 Ibid.

196 Rubén Medina, "El mestizaje a través de la frontera: Vasconcelos y Anzaldúa," Mexican Studies/Estudios Mexicanos, 25 (1): 112.

197 Lata Mani, "Multiple Mediations: Feminist Scholarship in the Age of Multinational Reception," Feminist Review, 35 (1990): 31.

${ }^{198}$ Norma Alarcón, "Chicana Feminism: In the Tracks of 'the' Native Woman," in Living Chicana Theory, ed. Carla M. Trujillo (San Antonio, TX: Third Woman Press, 1998). Gloria Anzaldúa, Borderlands/La Frontera: The New Mestiza (San Francisco, CA: Aunt Lute Books, 1987). Alicia Arrizón, Queering Mestizaje: Transculturation and Performance (Ann Arbor, MI: The University of Michigan Press, 2006). Karen M. Davalos, Exhibiting Mestizaje: Mexican (American) Museums in the Diaspora (Albuquerque, NM: University of New Mexico Press, 2001). Theresa Delgadillo, Spiritual Mestizaje: Religion, Gender, Race, and Nation in Contemporary Chicana Narrative (Durham and London: Duke University Press, 2011). Cherríe Moraga, "Queer Aztlán: The Reformation of Chicano Tribe," accessed May 30, 2016, https://thequeerartofutopia.files.wordpress.com/2012/04/moraga1.pdf. Chela Sandoval, "Mestizaje as Method," in Living Chicana Theory, ed. Carla M. Trujillo (San Antonio, TX: Third Woman Press, 1998).
} 
Chicana/o identity and culture as double-valenced." 199 How Chicano/a scholars have reformulated mestizaje and have deployed it as a strategic tool in order to build broader political coalitions and to challenge the racism endemic to US society should be a topic for discussion in future research.

\section{Conclusion}

In this chapter, I provided an overview of the theoretical concepts of race and nation and how they become entangled in the mythology of mestizaje in Mexico. I underscored how mestizaje has been successful in making race disappear from view by subsuming all differences under the aegis of national identity so that everyone becomes "just Mexican," thereby fostering the illusion of inclusion. However, mestizaje is responsible, as race studies scholar Miriam Jiménez Román argues, for the careful attention paid to phenotypical traits that can "expose" one's African or indigenous "genes," and "for the elaborate vocabulary that at once confers privilege and derides the subject under scrutiny." ${ }^{200}$ Mestizaje reveals itself to be paradoxical because it simultaneously celebrates mixture (on a rhetorical level) and valorizes whiteness (on a practical level). I have not outlined all the theoretical bases that guide this project because I think that interweaving data with theory throughout the next chapters makes for a stronger and more thorough dissertation that can make clear how mestizaje develops and morphs as it circulates across time and culture.

${ }^{199}$ Rafael Pérez Torres, Mestizaje: Critical Uses of Race in Chicano Culture (Minneapolis, MN: University of Minnesota Press, 2006), 16.

${ }^{200}$ Miriam Jiménez Román, "Looking at that Middle Ground: Racial Mixing as Panacea?" in A Companion to Latina/o Studies, ed. Juan Flores and Renato Rosaldo (Malden, MA: Blackwell Publishing, 2007), 330. 


\section{Chapter Three}

\section{Making the Nation: The Myth of Mestizaje}

The Mexican Revolution of 1910 brought about a newfound sense of nationalism that consolidated the figure of the mestizo, the product of indigenous and Spanish mixture, as Mexico's national race. Intellectuals as diverse as Andrés Molina Enríquez and Manuel Gamio "denounced the sterile aping of European doctrines" that characterized the Liberal period of the 1850s. ${ }^{201}$ These intellectuals in turn endorsed mestizaje, or the fusion of races and cultures, as a crucial process in forging a strong sense of nationhood and nationality. In this chapter, I examine the respective early works of Molina Enríquez and Gamio, Los grandes problemas nacionales (The Great National Problems, 1908) and Forjando patria (Forging a Nation, 1916). How do the authors define the Mexican nation? How does the mestizo become the "true Mexican"? What role do the authors allocate to indigenous peoples and women in the making of Mexico?

Molina Enríquez was a lawyer, writer, member of the Mexican Society of Geography and Statistics (1902), and professor of ethnology at the National Museum of History (1907) in Mexico City. In his ambitious work, Los grandes problemas nacionales, Molina Enríquez proposed general agrarian and socioeconomic reforms, and called for the dismantling of large haciendas and for the redistribution of land to the rural population, thus anticipating the revolutionary movement. He was further influential because of his contribution to drafting Article 27 of the 1917 Mexican Constitution, ${ }^{202}$

\footnotetext{
${ }^{201}$ David Brading, "Manuel Gamio and Official Indigenismo in Mexico," Bulletin of Latin American Research, 7 (1988): 75.

${ }^{202}$ Basave Benítez, México Mestizo, 49.
} 
which stipulated the state's obligation to redistribute land in the form of ejidos. ${ }^{203}$

Moreover, Molina Enríquez held many different bureaucratic posts, including the presidency of the National Agrarian Association in 1925.

Gamio for his part was an influential anthropologist. He worked as a professor of archeology at Mexico City’s National Museum, founded the Ministry of Agriculture's Department of Anthropology in 1917, worked as the director of the Inter-American Indigenous Institute from its inception in 1940 until his death in 1960, and had a brief stint in the Ministry of Public Education in 1924. His main role was to conduct statefunded, large-scale archaeological excavations and reconstructions of pre-colonial sites. As historian David Brading notes, the reconstruction of ancient monuments became "a distinctively Mexican industry...justified by the joint aim of recuperating national glory and attracting mass tourism." ${ }^{204}$ Gamio studied at Columbia University in 1909 with Franz Boas, who was a leading proponent of cultural relativism and one of the founders of the International School of Archaeology and Ethnology in Mexico City. Gamio was also renowned for his anthropological survey of the Teotihuacán region and population (see The Population of the Teotihuacán Valley, 1922), whose principal concern was to improve their living conditions. For example, he founded schools and medical clinics in Teotihuacán and petitioned for land reform on behalf of indigenous peoples. ${ }^{205}$

\footnotetext{
${ }^{203}$ Article 27, considered one of the greatest achievements of the Revolution, was dismantled in 1992 by the neoliberal government of Carlos Salinas de Gortari (19881994) as part of the larger project of privatization.

${ }^{204}$ Brading, "Manuel Gamio and Official Indigenismo in Mexico," 78.

205 Angeles González Gamio, "Manuel Gamio: El amor de un mexicano," La Jornada, August 26, 2012, accessed September 15, 2014, http://www.jornada.unam.mx/2012/08/26/sem-angeles.html?\#directora.
} 
Gamio's work is significant because, as anthropologist Salomón Nahmad Sittón points out, "it laid the foundations for an anthropology that would define itself as political, nationalist, and 'action oriented...' that would not only work closely with the state, but also share the goal of assimilating Indians and mestizos into Mexico's modern, Spanish speaking nation." ${ }^{206}$ In short, Gamio helped define an anthropology of official indigenismo that was to last until the $1970 \mathrm{~s} .{ }^{207}$ Moreover, I am interested in exploring the institutionalization of anthropology for its relation to Michel Foucault's notion of biopolitics: how does the study, regulation and integration of the poor and indigenous populations into mainstream society produce, according to Gamio, a homogeneous and strong Mexican nation?

I mention such biographical information to situate the works of Molina Enríquez and Gamio within the larger sociopolitical context. While Los grandes problemas nacionales and Forjando patria may not have been read by other than like-minded individuals, their ideas circulated in the public arena of politics, education and popular culture. Both authors, for example, were early proponents of mestizaje as integral to nation building, were active in the land reform movement, and were concerned with the

\footnotetext{
${ }^{206}$ Salomón Nahmad Sittón, "Mexico: Anthropology and the Nation-State," in A Companion to Latin American Anthropology, ed. Deborah Poole (Malden, MA: Blackwell Publishing, 2008), 129.

${ }^{207}$ Social anthropologist Antonio Carlos de Souza Lima notes that the term "indigenismo" is a product of Hispano-American literature dating from the nineteenth century, originally evoking a romanticized archetype of the indigenous. However, he observes that it was in "the Mexican political context following the 1910 revolution that the meaning of indigenismo became fixed, designating an [administrative] ideology of governmental action in relation to indigenous populations" ("Indigenism in Brazil: The International Migration of State Policies, in Empires, Nations, and Natives: Anthropology and State-Making, ed. Benoit L'Estoile et al. [Durham and London: Duke University Press, 2005], 200).
} 
excessive imitation of foreign culture and with developing an "authentic national art,"

which they considered to be a fundamental aspect of nationalism. ${ }^{208}$

The goal of this chapter is to investigate how Mexico is defined as a nation and mestizaje as the foundational national ideology. I first explore the institutionalization of anthropology, drawing from Foucault's concept of biopolitics. I then proceed to discuss the development of mestizofilia, ${ }^{209}$ or the exaltation of the mestizo as quintessentially Mexican, and how this contributes to the erasure of indigenous peoples and women from Mexican history.

\section{Anthropology and the State}

Mexican anthropology is often described as a national or nation-centered anthropology $\mathrm{y}^{210}$ for the crucial role it has played in the projects of national consolidation. For example, the educated elite científicos (scientists) of the Porfirio Díaz era were concerned with shaping a favorable image of Mexico to attract foreign investment. ${ }^{211}$

\footnotetext{
${ }^{208}$ Gamio, Forjando patria, 40, 52.

${ }^{209}$ Political scientist Agustín Basave Benítez coined the term "mestizofilia."

${ }^{210}$ The difference between a national and metropolitan anthropology is that the former is primarily focused on nation building and the latter extends its research across nations. Interestingly enough, "the more a state has the capacity to project itself abroad (in colonial or hegemonic form), the more its anthropologists will tend to undertake fieldwork beyond national borders," thereby revealing the asymmetries of power between nations (Benoit L'Estoile et al., Empires, Nations, and Natives: Anthropology and StateMaking [Durham and London: Duke University Press, 2005], 20).

${ }^{211}$ One of the more prominent cientificos was the educator Justo Sierra, whose publication, Mexico: Its Social Evolution, printed in English, countered point by point the negative comments that E.B. Tylor and other leading Anglo anthropologists offered in their travel books. The main strategy of Sierra and other científicos, whom Molina Enríquez admires and cites in Los grandes problemas nacionales, was to make Mexico's evolution and development comparable to "that of the nations that produce anthropologists who travel" (Claudio Lomnitz, "Bordering on Anthropology: Dialectics of a National Tradition in Mexico," in Empires, Nations, and Natives: Anthropology and State-Making, ed. Benoit L'Estoile et al. [Durham and London: Duke University Press, 2005], 178).
} 
Later, revolutionary anthropologists were committed to social and agrarian reforms and intervened directly in indigenous communities. Lomnitz notes that anthropology's identification with official nationalism in Mexico took shape from the 1940s to the late 1960s, when most of the state institutions dedicated to anthropology were built: the National School of Anthropology and History (1939), which had a monopoly over the training of anthropologists, the National Institute of Anthropology and History (1939), which was one of the country's most important research institutions and sites for cultivating images of the nation, the Inter-American Indigenous Institute (1940), the National Indigenous Institute (1948), where ideas of cultural relativism and acculturation flourished, and the internationally renowned National Museum of Anthropology (1964). Moreover, anthropology was directly linked to the diverse policies of indigenismo that included imparting bilingual education, building rural schools and devising development programs for indigenous communities. Most of these programs were concentrated in the National Indigenous Institute, which was also the main source of employment for anthropologists. The official role of anthropology, Lomnitz argues, was to forge "Mexican citizenship both by 'indigenizing' modernity and by modernizing the Indians, thus uniting all Mexicans in one mestizo community." ${ }^{212}$ In other words, anthropology worked with the state to assimilate indigenous peoples in order to consolidate the vision of a homogeneous Mexican nation.

According to anthropologists Benoit de L'Estoile, Federico Neiburg and Lygia Sigaud, Mexican anthropology illustrates the "mutual interdependence" that exists between scientific practice and the state, between knowledge production and policy

${ }^{212}$ Lomnitz, Deep Mexico, Silent Mexico, 231. 
implementation. Science operates in the field of state action in two main ways:

instrumentalizing and legitimizing. In other words, science has the tools to identify the problems that need to be addressed by public policies at the same time that it provides the arguments that can legitimize "the aims and means of such policies and those who implement them." ${ }^{213}$ The state for its part supports academic institutions to appear rational and objective. L'Estoile et al. further explain that the state and scientific practices reinforce each other in a circular process in so far as the very existence of a discipline like anthropology, designed for the study of human differences, offers "scientific confirmation of the need to design policies premised on such differences. Conversely, the need to develop specific policies in response to a population's distinctive traits comprises a strong argument for developing scientific knowledge about this population." ${ }^{214}$ In the Mexican case, state institutions recruited anthropologists in large numbers in order to develop, administer and implement governmental policies. The state relied on anthropological knowledge about indigenous groups to both inform and legitimize its policies regarding their integration.

This section focuses on Gamio because he is generally considered to be the founder of modern Mexican anthropology. Much like the científicos, Gamio believed in the degeneration of the indigenous races after the Conquest and in the grandeur of preColumbian civilizations. However, he distinguished himself from his predecessors because of his re-valorization of indigenous cultures and direct involvement in their communities. For Gamio, the role of anthropologists was "to intervene as the enlightened arm of government [and] the arm of science" in order to promote social harmony and

\footnotetext{
${ }^{213}$ Benoit L'Estoile et al., Empires, Nations, and Natives, 11.

214 Ibid., 14.
} 
development. ${ }^{215}$ In short, Gamio felt that "the actions of the anthropologists were the actions of the nation itself." ${ }^{216}$ For example, Gamio claims that it is necessary to "forge oneself - if only temporarily - an indigenous soul...to work for the advancement of the indigenous class." ${ }^{217} \mathrm{He}$ adds that this "task is exclusively destined for the anthropologist and the ethnologist in particular," whose discipline requires him to be without prejudices. ${ }^{218}$ Such statements position Gamio at the outset as the voice of authority and reason, as the spokesperson for the nation. ${ }^{219}$ They also underscore the temporal representation of indigenous peoples, who are imagined as being stuck in culture and as waiting to be brought into modern civilization by the mestizo intellectual.

Cultural anthropologists have observed that anthropology as a discipline formed under the paradigm of evolutionism, which relied on a conception of time that was secularized, naturalized and spatialized. ${ }^{220}$ Anthropology's construction of its relation with its "Other" then "implied affirmation of difference as distance;" a distance that was required so that it could be overcome in time (emphasis in original). ${ }^{221}$ The conception of evolutionary time as "natural," Johannes Fabian points out, "promoted a scheme in terms

\footnotetext{
${ }^{215}$ Lomnitz, Deep Mexico, Silent Mexico, 251.

216 Ibid.

${ }^{217}$ Gamio, Forjando patria, 25.

218 Ibid.

${ }^{219}$ Anthropologist João Pacheco de Oliveira notes that the tendency of the indigenista anthropologist to speak on behalf of indigenous interests is an inheritance from the colonial era and serves, on the one hand, to legitimize anthropologists as a professional group and, on the other, to exclude indigenous peoples from the decision-making processes ("The Anthropologist as Expert: Brazilian Ethnology Between Indianism and Indigenism," in Empires, Nations, and Natives: Anthropology and State-Making, ed. Benoit L'Estoile et al. [Durham and London: Duke University Press, 2005], 241-243). ${ }^{220}$ Fabian, Time and the Other. Pacheco de Oliveira, "The Anthropologist as Expert." Giordano Nanni, The Colonisation of Time: Ritual, Routine and Resistance in the British Empire (Manchester, UK: Manchester University Press, 2012).

${ }^{221}$ Fabian, Time and the Other, 16, 146.
} 
of which not only past cultures, but all living societies were irrevocably placed on a temporal slope, a stream of Time - some upstream, others downstream."222 The terms “civilization," “evolution," "progress," "modernization," “development," "acculturation," "primitive," "savage" and so on are all derived from the Western conception of evolutionary Time. The works of Gamio and Molina Enríquez prove illuminating here for how they reproduce what Fabian calls "denial of coevalness," that is, "a persistent and systematic tendency to place the referent(s) of anthropology in a Time other than the present of the producer of anthropological discourse." ${ }^{223}$ In other words, the indigenous person in Mexican intellectual discourses is imagined as an example of a traditional, primitive and archaic being who is trapped in the past and is doomed to disappear if it were not for the efforts of the state and its agents, thereby reinforcing the role of anthropologists as the protector of indigenous interests.

Gamio conceives of anthropology as crucial for the performance of "good government" because it is the means by which to know the current population and improve its condition. ${ }^{224}$ It is useful here to relate Gamio's views on anthropology to Foucault's notion of biopolitics, which he defines as the right to "make" live, that is, to "administer" and "optimize" life. ${ }^{225}$ Foucault explains that in the second half of the eighteenth century, a new technology of power emerged that was not exclusively centered on the individual human body, as the techniques of discipline had been; this was a "massifying" force directed at "man-as-species" rather than "man-as-body," which he

\footnotetext{
222 Ibid., 17.

223 Ibid., 31.

${ }^{224}$ Gamio, Forjando patria, 15, 59.

${ }^{225}$ Michel Foucault, Society Must Be Defended, trans. David Macey (London: Penguin Books, 2004).
} 
calls a "'biopolitics' of the human race."226 Biopolitics involved knowing and controlling the birth rate, the mortality rate, life expectancy and longevity, the rate of reproduction and the fertility of a population, as well as the effects of the environment. As a politics for the optimization of life, biopolitics had to qualify, measure, appraise and hierarchize. It was at this time that various technologies of representation and measurement, such as the census and statistics, emerged not to discipline but to regularize and manage the population. Statistics, for example, determined such concepts as "population," "type" and "normal," and were deemed necessary to govern. ${ }^{227}$ Moreover, the census imagined that all members of the population had one - and only one - clear place in it. ${ }^{228}$ L'Estoile et.al further observe that statistics, census counts, ethnographic maps, museums and so on were all part of the process of constructing and stabilizing categories of identity, "insofar as they contribute[d] to providing scientific and legal backing of the existence of certain groups... while potentially denying such legitimacy to other groups. ${ }^{229}$ In sum, Foucault argues that the aim of biopolitics was "to establish a sort of homeostasis" through these technologies of measurement and "to achieve an overall equilibrium that protect[ed] the security of the whole from internal dangers." ${ }^{230}$

In his analysis of Mexican statistics, social anthropologist Casey Walsh comments that during the Porfirian era, statistics were more enumerative and were concerned with measuring and tracking the changes in production, profit, currency exchange and imports

\footnotetext{
226 Ibid., 243.

${ }^{227}$ Casey Walsh, "Statistics and Anthropology: The Mexican Case," in A Companion to Latin American Anthropology, ed. Deborah Poole (Malden, MA: Blackwell Publishing, 2008), 353.

${ }_{228}$ Anderson, Imagined Communities, 166.

${ }^{229}$ L'Estoile et al., Empires, Nations, and Natives, 16.

${ }^{230}$ Foucault, Society Must be Defended, 249.
} 
and exports, which were perceived to be numerical indicators of Mexico's progress.

Furthermore, the European whiteness of Mexico was imagined in the statistical graphs and charts of improvements in hygiene, education, electricity and transportation. ${ }^{231}$ These statistics circulated and were displayed at international expositions, such as the Chicago's World Fair, in the hope that they would inspire confidence among foreign investors. Walsh argues that Gamio's Forjando patria was a reaction against such quantitative knowledge, calling for the anthropological recognition of "the existence of 'the Indian' and 'the mestizo' as social types and actors." 232 For example, in a short chapter entitled "Some considerations about statistics," Gamio remarks that statistics in Mexico must proceed according to a "nationalist criteria" that takes into consideration the heterogeneity of the country. He continues, "to have the knowledge and ethnographic classification of the diverse social groups [is indispensable] so their activities and characteristics can converge and develop harmoniously, and to pave the ground for social cohesion, which is inherent in every defined nationality." ${ }^{233}$ Gamio here posits the standardized knowledge of the population as the means to achieve the desired homogeneity viewed as essential for the consolidation of the Mexican nation. A final point to make here is that Gamio also conducted census counts across the country, opting for the statistical analysis of material culture as one of the methods ${ }^{234}$ by which to

\footnotetext{
${ }^{231}$ Walsh, "Statistics and Anthropology," 359.

232 Ibid., 362.

${ }^{233}$ Gamio, Forjando patria, 35.

${ }^{234}$ In Forjando patria, Gamio proposes an integrative research method for the study of the national population from different viewpoints: quantitative (statistics and the census), qualitative (physical type, language, civilization, culture), chronological (pre-colonial, colonial and contemporary periods) and environmental.
} 
identify the racial composition of the nation and to identify the social groups in need of improvement.

The study Gamio offers in the appendix of Forjando patria is a good example of the biopolitics endemic to indigenismo. In the study, Gamio classifies the material and cultural characteristics of various indigenous groups to determine which characteristics are "useful and beneficial," which are lacking, and which are "harmful" and thus have to be "corrected" or "substituted," all with the aim of "normalizing" the "deficient development" of these groups. ${ }^{235}$ All of this is neatly illustrated in a chart, in which several items, such as corn grinding stone, phonograph, machete, sandals and corn tortillas are classified according to culture (indigenous, European, mixed), utility (efficient, deficient, harmful), type (diet, tools, clothing), origin (regional, national, foreign) and the frequency of use. ${ }^{236}$ Gamio explains that his method consisted in making an inventory of all the objects owned by the various families he visited across different rural regions in Mexico. ${ }^{237}$

Gamio proposes three different criteria with which to determine the utility of such material characteristics: scientific, conventional (indigenous) and a mixture of the two. First, the scientific criteria must be exclusively applied to hygiene, medical services and agricultural tools to ensure the "improvement" of the population's "biological development" and the reduction of mortality rates, which are indigenismo's principal concerns. ${ }^{238}$ Second, conventional wisdom applies to indigenous artwork and music that should be left intact. Third, a mixture of scientific and conventional criteria applies to

\footnotetext{
${ }^{235}$ Ibid., 192.

${ }^{236}$ Ibid., 186.

${ }^{237}$ Ibid., 187.

${ }^{238}$ Ibid., 193-194.
} 
indigenous political organization and institutions. Gamio observes that while it is "unfair" to impose a European-style democracy on indigenous peoples, they should not be allowed to become "absolutely autonomous nationalities" because this would further "condemn them to their deficient development and perhaps their rapid extinction..."239 Note how the frequent use of the word "deficient" (from the Latin deficere, meaning "to be wanting") serves to frame indigenous peoples as not being fully human. Furthermore, Gamio's statement here says more about the concern at large of heterogeneity and its supposed threat to the stability of the national whole than about the welfare of indigenous peoples. The indigenismo movement feared that if indigenous populations had too much freedom to organize, they would continue to be loyal to their communities and territories, which was perceived to be an obstacle to achieving modernity and a true sense of nationhood. Overall, Gamio's study links differences in material culture to racial evolution, explicitly stating that the percentage of objects from a mixed or European origin is larger among those indigenous groups with a "higher evolutionary development." ${ }^{240}$ Moreover, this study is indicative of anthropology's denial of coevalness because the indigenous groups under scrutiny here are framed as belonging not so much to Gamio's present as to previous stages of development.

The paradox of Gamio's anthropology is that while he valorizes indigenous cultures, he positions indigenous peoples as redeemable through the process of mestizaje, or what he calls "the happy fusion" of races and cultures. ${ }^{241}$ The recurrent use of the words "happy" and "harmonious" is interesting because it highlights the post-

${ }^{239}$ Ibid., 199.

${ }^{240}$ Ibid., 196.

241 Ibid., 13. 
revolutionary utopic thinking that viewed the process of acculturation as an agreeable means by which to preserve the positive aspects of indigenous cultures and eliminate the negative ones, ignoring the violence and loss implicit in this process. And of course, it was ultimately intellectuals and the elite who decided what was worth preserving and integrating into the national culture and what was not. Having explored the relation between anthropology and the state, I now turn my attention to discussing how the figure of the mestizo emerges as the "true Mexican" in the key works of Gamio and Molina Enríquez.

\section{The Cult of the Mestizo}

From the colonial period and onward, indigenous peoples have been considered

inferior to Spaniards, but redeemable through marriage strategies and adoption of Spanish religion, language and culture. For example, the casta (caste) paintings of the eighteenth century (discussed at greater length in chapter eight), which depicted the child of a Spaniard and an indigenous person as a mestizo, the child of a mestizo and a Spaniard as a castizo and the child of a castizo and a Spaniard as a Spaniard, underscored the possibility to transcend an individual's indigenous origins through intermarriage with Europeans and to achieve whiteness, or at least proximity to it. The manipulation of racial identity that characterized colonial Mexico is best illustrated in the tendency of parents to alter their children's birth certificates to classify them as creoles rather than mestizos or any other lower caste.

The Mexican Independence movement of 1810 abolished slavery and other forms of legal discrimination, including the castas. However, Lomnitz observes that racial 
manipulation continued "above all in the struggle for status." ${ }^{242}$ The aspiration for whiteness remained prevalent after independence because whiteness represented the only position where wealth, status and power were in equilibrium - this helps explain why president Porfirio Díaz (1876-1911), the mestizo hero in Molina Enríquez’s work, powdered his face white and why dark-skinned politicians and wealthy men "had an exaggerated preference for white wives." ${ }^{243}$ As stated in an earlier chapter, the preference for whiteness underscores the pervasive logic of blanqueamiento embedded in mestizaje, which dreams of improving the Mexican race (or mejorar la raza) through whitening. Social anthropologist Peter Wade observes that whiteness and social status are intimately intertwined: "there are structural links between vertical mobility and whitening which create a general association between being 'whiter' and having more money, education and power." ${ }^{244}$ In other words, to aspire for whiteness is to struggle for a higher status.

During the Liberal period of the 1850s, Juárez and his administration sought to redeem indigenous peoples by providing access to citizenship and all that it entailed: universal rights, equality under the law and free education. But in practice, Juárez's laws, and later Díaz's, contributed to the exclusion and impoverishment of indigenous populations by eroding the calpulli (similar to the ejido), exploiting their labor and devoting Mexico's scant resources to capitalist investments. ${ }^{245}$ At this time, the term "Indian" became conflated with class factors to designate other non-full citizens, including poor peasants. Moreover, Lomnitz argues that the theories of Charles Darwin and Herbert Spencer became prominent because they allowed the Mexican elite to blame

\footnotetext{
${ }^{242}$ Lomnitz, Deep Mexico, Silent Mexico, 51.

243 Ibid.

${ }^{244}$ Wade, Race and Ethnicity in Latin America, 77.

${ }^{245}$ Lomnitz, Deep Mexico, Silent Mexico, 52.
} 
the poor and indigenous populations for the country's failure to reach the desired level of economic and social development of the US and Europe. ${ }^{246}$ Hence, the "Indian" became a condition to overcome in order to achieve progress and modernity.

A further popular idea to modernize and whiten the Mexican nation during Díaz's era was to attract European immigrants because, according to the aforementioned positivist thinker Sierra, "only European blood can keep the level of civilization...from sinking, which would mean regression, not evolution." ${ }^{247}$ While Molina Enríquez displays admiration for Sierra, he dismisses foreign immigration as "absurd." ${ }^{248} \mathrm{He}$ argues that increasing the mestizo population is essential to establish the Mexican nationality and patria (homeland). ${ }^{249} \mathrm{He}$ defines patria as a family that shares a common territory, origin, religion, language, customs, aspirations and evolutionary type. In short, patria is to have unity and to share a "common ideal.."${ }^{250}$ Molina Enríquez worries throughout his book that there is no sense of communion in Mexico because of its heterogeneous racial composition that includes indigenous peoples, mestizos and criollos. ${ }^{251} \mathrm{He}$ contends that the "dissolution and integration" of criollos and indigenous

\footnotetext{
${ }^{246}$ Ibid.

${ }^{247}$ Quoted in Knight, "Racism, Revolution, and Indigenismo," 78. Such line of thinking was not uncommon among intellectuals and government officials of the time. For example, historian Francisco Pimentel commented in 1856, "I consider European immigration to be the only means to save this country." The governor of the northern state of Chihuahua, Enrique Creel, for his part affirmed, "a white immigrant is worth more than five Indians" (quoted in Tomás Pérez Vejo, "La extranjería en la construcción nacional mexicana," in Nación y extranjería: La exclusión racial en las políticas migratorias de Argentina, Brasil, Cuba y México, ed. Pablo Yankelevich [Mexico: Universidad Nacional Autónoma de México, 2010], 164, 172).

${ }^{248}$ Andrés Molina Enríquez, Los grandes problemas nacionales (Mexico: Instituto Nacional de la Juventud Mexicana, 1964), 239.

${ }^{249}$ Ibid., 265.

${ }^{250}$ Ibid., 278.

${ }^{251}$ Ibid., 286.
} 
peoples into the mestizo element is "indispensable for the creation of a strong nationality. ${ }^{" 252}$ It is interesting to note that his concern to dissolve the criollo groups, which he considers the more advanced in terms of evolution and civilization, is not purely racial but political as well. A deep anxiety over foreign encroachment (particularly from the United States) runs throughout Los grandes problemas nacionales, which is not surprising considering that the French intervention (1861) and the war with the US (1846-1848), in which Mexico lost half of its territory, were not such distant memories to Molina Enríquez. In fact, he makes the claim that the "creation" and "consolidation of the patria" are crucial for the "salvation of nationality" and "to fight off foreign powers." 253

The valorization of the mestizo as the beacon of Mexican-ness took on added force after the Revolution ended in 1917. At this time, intellectuals such as Gamio sought to distance themselves from the predominant Eurocentric, racist doctrines, adopting instead the theory of the inheritance of acquired characteristics. This theory, developed by the French naturalist Jean Baptiste de Lamarck, posited that changes to an individual caused by environmental factors could be passed down to offspring and become part of its hereditary composition. Historian Alexandra Stern notes that neo-Lamarckism became popular in Mexico "because it implied that human actors were capable... of improving the national 'stock' through environmental intervention and, eventually, of generating a robust populace, ${ }^{, 254}$ thereby legitimating the politics of indigenismo (or assimilation) that the likes of Gamio endorsed. However, the works of Gamio and Molina Enríquez are

252 Ibid., 315.

253 Ibid., 332.

${ }^{254}$ Stern, "From Mestizophilia to Biotypology," 190. 
inherently paradoxical because their celebration of mestizaje remains steeped in racist ideology.

Los grandes problemas nacionales is divided into two parts, each with five chapters. The first part provides a general overview of Mexico's territory, history and property laws, and ends with Molina Enríquez declaring his alliance to president Porfirio Díaz in the chapter entitled "The secret to Porfirian peace." The second part outlines what the author considers to be the great national problems: property, land credit, irrigation, population and politics. Molina Enríquez's principal concerns are neatly summarized in a chart on the first chapter, in which notions of private property are correlated to evolutionary development, with the nomad indigenous framed as the "biggest obstacles" to the country's stability and progress. ${ }^{255}$ This chart reappears throughout the book and emphasizes one of his central arguments: the equitable distribution of land can transform the previously disadvantaged social groups (mestizos and indigenous peoples) into a propertied class, thus ensuring the consolidation of the Mexican nation.

The correlation between race and class is made more explicit in the population chapter. In this chapter, Molina Enríquez explains that foreigners and creoles, divided by occupation as landowners, politicians and members of the upper clergy, and some mestizos, divided as members of the political directorate, bureaucracy and upper working class, all constitute the privileged classes in Mexico. ${ }^{256}$ The lower classes, on the other hand, are comprised of indigenous peoples and poor mestizos, and are divided into soldiers, villagers, peons and the urban working class. ${ }^{257}$ Molina Enríquez observes that

${ }^{255}$ Molina Enríquez, Los grandes problemas nacionales, 53.

${ }^{256}$ Ibid., 223.

${ }^{257}$ Ibid. 
under such hierarchical divisions, "our social body is a disproportionate and deformed body; from the thorax and above, [the body] is a giant, [and] from the thorax and below, it is a child...[the body] is in danger of falling. Its feet are weakening day by day. $" 258$ This passage is interesting because it highlights the unequal relations of power and ownership embedded in the idea of the social body that emerged, according to cultural historian Mary Poovey, as a technique for disciplining certain bodies by promising "full membership in a whole." ${ }^{259}$ By comparing the poor and indigenous populations to a child, Molina Enríquez recognizes that these sectors of society have been exploited to the point of exhaustion as the supportive limbs of the wealthy few. The images of a growing giant and a debilitating child, who is losing strength day by day, not only underscore the socioeconomic disparities that characterize Mexican society but serve as a powerful call for structural reform. The author argues that it is urgent to distribute property among the disadvantaged groups of mestizos and indigenous peoples in order to create a middle class that can dismantle the concentration of power and capital among the privileged classes.

Molina Enríquez begins his treatise by describing the Conquest as Mexico's formation period, in which the mixture of Spaniards and indigenous peoples produced the hybrid element of the mestizo. He praises the republican government that emerged after independence for furthering the "contact and mixture between races, paving the way for the formation of one. ${ }^{, 260} \mathrm{He}$ then provides an overview of the characteristics of the three predominant racial elements. For example, the criollos are of "high blood," "blond,"

\footnotetext{
${ }^{258}$ Ibid., 224.

${ }^{259}$ Mary Poovey, Making a Social Body: British Cultural Formation, 1830-1864 (Chicago, IL: The University of Chicago Press, 1995), 8.

${ }^{260}$ Molina Enríquez, Los grandes problemas nacionales, 62.
} 
"worldly," "cultured" and "refined." In short, they are "gente decente" (or respectable people). ${ }^{261}$ Second, indigenous peoples are "passive," "submissive," "resigned" and "evolutionary backward," but of great resistance and energy. ${ }^{262}$ And third, mestizos are "poor," "vulgar" and "rude," and reflect "the defects and vices" of both Spaniards and indigenous peoples. ${ }^{263}$ This initial depiction of the mestizo is in line with the idea prevalent at the time that hybrids were fundamentally degenerate. However, Molina Enríquez rescues the image of the mestizo in no time, observing that after the MexicanAmerican war that left the criollos politically weakened, mestizos, better suited to adaptation and integration, emerged as the leading class and race. ${ }^{264}$ Moreover, the Reforma (or Liberal) period that instituted the separation of church and state and nationalized the church's property allowed mestizos to become a propertied class, thereby consolidating its political power and leadership. He argues that such consolidation of power "has meant the strengthening of nationality." ${ }^{" 265}$ Here the conflation of race and class is as evident as in the term "Indian," for the mestizo first rises as a political class to then become the superior, strongest and more patriotic race, which represents the "true nationality." 266

The epitome of the mestizo leader for Molina Enríquez is Díaz, whom he describes as a patriot and a friend of the people. He praises Díaz for granting political posts to mestizos and "kindness" to indigenous peoples who are "incapable of social

\footnotetext{
${ }^{261}$ Ibid., 63.

262 Ibid., 64.

263 Ibid., 65-66.

${ }^{264}$ Ibid., 68.

${ }^{265}$ Ibid., 84.

266 Ibid., 85.
} 
action, ${ }^{267}$ thus framing the latter's well-being as dependent on the actions of the former. Furthermore, he attributes the tenuous unity of the country to Díaz's concentration of power, which lasted for 35 years, to his ability to dominate all other classes and to punish "without mercy" those who disturb the peace. ${ }^{268}$ Molina Enríquez here justifies the massacre and violent repression of the indigenous populations from the North, particularly the Yaqui from the state of Sonora who actively fought Díaz to preserve their land.

Molina Enríquez's evolutionism is best exemplified in the penultimate chapter entitled El problema de la población (The Population Problem). In this chapter, he discusses the "anthropological and ethnic nature" of indigenous peoples and mestizos, among other aspects. ${ }^{269} \mathrm{He}$ presents what he calls "scientific notes" 270 on indigenous peoples and their biological characteristics (brain, teeth, face) to conclude that they have a superior muscular strength compared to that of animals and a superb ability to adapt to the environment. ${ }^{271}$ Note that Molina Enríquez repeatedly emphasizes the physicality of indigenous peoples, but accords no intellect to them and thus legitimates the belief that they need the guidance and leadership of the mestizo. The author further points out that while whites may be superior in terms of their ability to act because of their "advanced

\footnotetext{
${ }^{267}$ Ibid., 68, 95.

${ }^{268}$ Ibid., 88.

${ }^{269}$ Ibid., 247.

${ }^{270}$ These scientific notes, which review in a dry tone a series of topics that range from "the nature of human life" (36) to "the social construction of the population" (216), are common throughout the book and serve an important purpose: to provide Molina Enríquez a semblance of objectivity and rationality. In this way, his depiction of indigenous peoples as subordinate to mestizos appears to be the natural order of things. ${ }^{271}$ Ibid., 253. This section of the book borrows extensively from the work of the Mexican writer and politician Vicente Riva Palacio, who in turn cites at length Charles Darwin's The Descent of Man.
} 
evolution," indigenous peoples are superior because of their "resistance" and "more advanced selection" (emphasis in original). ${ }^{272}$ In other words, Molina Enríquez views selection, or the ability to adapt to the environment, as superior to evolution. He then attributes the decline of the Spanish empire, the rise of the mestizo population and the inevitable victory of Mexico in the future ethnic struggle against other countries (revealing once again his anxiety over foreign invasion) to this advanced selection. ${ }^{273}$

In his discussion of the mestizo population, Molina Enríquez again borrows from Riva Palacio, who argues that the mestizo is "the race of modern Mexicans...the true Mexican, the Mexican of the future, as different from the Spanish as from the indigenous..." but insists that the traits of Spaniards are likely to predominate in its offspring. ${ }^{274}$ Molina Enríquez agrees that the mestizo is quintessentially Mexican, but views the indigenous element as more prevalent in the make-up of the mestizo. He thus explains that the mestizo is not a new race, but "the indigenous race favorably modified by Spanish blood" (emphasis mine). ${ }^{275}$ The mestizo as such is both a man of action and resistance, and is better suited to absorb indigenous peoples and criollos into his element, thereby creating the "true national population." ${ }^{.276}$ According to the author, the mestizo, being the superior racial element and leading political class, is essential for Mexico's "well-being."277

Despite the valorization of the mestizo as the embodiment of Mexican-ness, Molina Enríquez reproduces many racist assumptions, evident in his description of

\footnotetext{
272 Ibid., 254.

${ }^{273}$ Ibid., 259.

274 Ibid., 254.

275 Ibid., 258.

${ }^{276}$ Ibid., 259.

${ }^{277}$ Ibid., 265.
} 
indigenous peoples as evolutionary backward and in his admiration for the civilization and culture of criollos, which he sees as more advanced. Although aesthetics is a topic for discussion in the next chapter, it is worth noting that Molina Enríquez considers mestizos to be neither beautiful nor cultured because of their previously miserable socioeconomic condition. However, he argues that if their well-being is increased, their "type will become more beautiful and refined" to reach the level of criollos. ${ }^{278} \mathrm{~A}$ further point to raise here is that if the mestizo is constantly aspiring for improvement or "perfection," ${ }^{279}$ then perhaps to be mestizo is not an end in itself, as mestizaje purports, but it is a means to achieve an elusive "more" - more status, more beauty, more whiteness.

The depiction of indigenous peoples in Gamio's work is unsurprisingly more romanticized given that he was writing at the height of the Mexican Revolution, which brought about an upsurge in nationalism. Forjando patria is an ambitious book divided into 34 short chapters and an appendix that covers a wide range of topics, including history, art, politics, religion, language, national literature, national industry, education and indigenous groups (see chapters four and five: "The Redemption of the Indigenous Class" and "Prejudices about the Indigenous Race and their History"). The book also devotes considerable space to the disciplines of anthropology, archeology and sociology, and their relation to government.

Gamio states in the preface that his book is "collective" because it is "inspired" by his "observation of the different social classes" and because its pages are made of "the

${ }^{278}$ Ibid., 308.
${ }^{279}$ Ibid., 298. 
flesh and soul of the people." 280 However, because illiteracy rates at the time were high, it is unlikely that his intended audience were "the people." Gamio here is not so much speaking to but for "the people," while addressing fellow mestizo intellectuals and other leaders of the Revolution. Gamio begins the first chapter with the lofty statement that the task of Mexican revolutionaries is to create the "new patria" from the mixture of "iron and bronze." ${ }^{281}$ He notes that unlike the Independence movement that "abandoned" indigenous groups, the Revolution will incorporate them into the nation. ${ }^{282} \mathrm{He}$ laments that the lack of knowledge of the indigenous" "soul, culture and ideals" is a hindrance to their integration and in turn, to forging a Mexican nationality. ${ }^{283} \mathrm{He}$ proposes an anthropological investigation as the "only way" by which to know and advance the condition of indigenous peoples. ${ }^{284}$ Gamio is particularly fond of citing his own anthropological endeavors as an example that others should follow, thereby helping to consolidate anthropology as a profession integral to the projects of national consolidation.

Gamio shifts from the language of biology, although not disavowing it entirely, to one of culture in order to point out that indigenous peoples may be "culturally stuck," but they have the capacity to "embrace contemporary culture" like any other race if only their "diet, apparel and education were to be improved." 285 It is interesting to contrast Gamio and Molina Enríquez here because while they both argue that a homogeneous race and a unified language and culture are the bases of nationalism, their approach to achieving this differs. For example, Molina Enríquez dismisses education and other "sociological

\footnotetext{
${ }^{280}$ Gamio, Forjando patria, 3.

${ }^{281}$ Ibid., 6.

${ }^{282}$ Ibid., 9.

283 Ibid., 15.

${ }^{284}$ Ibid.

285 Ibid., 24.
} 
panaceas" as insignificant in the evolution of indigenous peoples because it is ultimately a matter of nature. ${ }^{286} \mathrm{He}$ adds that the indigenous' evolution can be accelerated by making them into a propertied class, as well as by increasing their contact and mixture with mestizos, who will absorb and transform them by virtue of their superiority. ${ }^{287}$ Gamio for his part is a strong proponent of education as a means to improve the living conditions of indigenous peoples and to successfully assimilate them into the dominant culture. ${ }^{288}$ For example, Gamio explicitly frames education as a civilizing agent in a separate document: "[education will] lift them all to the same plane of civilization. And by civilization I do not mean merely teaching the Indian how to read. I mean teaching him that he walks on rich soil and that there is a world around him. Throughout four hundred years he has stagnated miserably and has not even known it. He has not seen the failure of his efforts. He thinks he leads a normal existence; education will make him see that he can lead a better one and how he can do so" (p.154). ${ }^{289}$ The use of the word "stagnate" is interesting for it denotes stillness, inactivity and deterioration. Indigenous peoples here are framed as being trapped in an earlier stage of development, who must adopt the customs of the dominant culture in order to enter modernity and inhabit the normative. Moreover, this idea that education could function as a means to improve the well-being of indigenous peoples and to achieve their integration proved highly

\footnotetext{
${ }^{286}$ Molina Enríquez, Los grandes problemas nacionales, 317.

${ }^{287}$ Ibid.

${ }^{288}$ Nahmad Sittón remarks that Gamio initially supported the teaching of Spanish as a unifying language, but reversed his position and began to promote indigenous languages as part of national culture in the 1940s, after the Mexican post-revolutionary state had been consolidated and the threat of US invasion had been reduced ("Mexico," 130). ${ }^{289}$ Such comments were part of a series of lectures Gamio delivered at the University of Chicago in 1926, which were sponsored by the Norman Wait Harris Memorial Foundation and also featured the philosopher José Vasconcelos (see next chapter).
} 
influential to the development of Mexican anthropology and indigenismo in subsequent decades (see chapter six).

The inherent paradox in Gamio's work is that while he exalts pre-Columbian indigenous societies as the seed and soul of Mexico, he treats contemporary indigenous groups as stagnant and trapped in the past, as "dead worlds" obstructing the road to modernity. ${ }^{290}$ For example, he observes, "the Indian continues to cultivate pre-Hispanic culture and this will continue until we achieve his gradual, logical and sensible incorporation into contemporary civilization." ${ }^{291} \mathrm{He}$ thus positions his world, "our civilization" as he later calls it, as the superior foundation on which to build the Mexican nation. The one aspect of indigenous culture deemed valuable for the nation is their artwork. According to Gamio, indigenous art should be kept away from European influence in order to "flourish spontaneously" and to maintain the "high values" that distinguish it. ${ }^{292}$ Both Gamio and Molina Enríquez exhibit a deep anxiety over the excessive imitation of foreign culture and conveniently resort to indigenous art to provide an element of uniqueness and folklore to the inchoate national culture. ${ }^{293}$

The final aspect to discuss in this section is how the cult of the mestizo erases the agency of not only indigenous peoples (as shown above) but of women in the nationbuilding projects. Note how for Gamio and Molina Enríquez the product of an indigenous woman and a Spanish man is always a mestizo and not a mestiza, as if only a man is

\footnotetext{
${ }^{290}$ Guillermo Bonfil Batalla, México Profundo: Reclaiming a Civilization, trans. Philip A. Dennis (Austin, TX: University of Texas Press, 1996), 55.

${ }^{291}$ Gamio, Forjando patria, 96.

292 Ibid., 201.

${ }^{293}$ As anthropologist Bonfil Batalla points out, the indigenous continues to be commoditized today as something unique that "provides a touch of local color, an accent of the exotic to attract tourists" (México Profundo, 55).
} 
suited for the task of consolidating the nation. For example, in one of his many so-called "scientific notes," Molina Enríquez biologically grounds men as providers of food and protection and women as reproductive beings, thus naturalizing gender roles. He further argues in Darwinian terms that feminism, which he narrowly defines as having women working outside the home, is "truly absurd" because women are weaker and incapable of competing, or "struggling," against men in the workforce, which results in their "inevitable defeat" and in men having to provide for them anyway ${ }^{294}$ Moreover, Molina Enríquez correlates the increase of women in the workforce with a decrease in the reproduction of the population, which he sees as "detrimental to society." ${ }^{295}$ One of his principal concerns is to raise Mexico's population to 50 million people, without recourse to immigration, in order to create a strong and sovereign nation that can defend itself against foreign powers. However, he does not seem too worried about feminism because he considers it to be an American ideal. He argues that Mexican customs are "more in accordance with the nature [of women]," which can lead to "forming better families" and in turn, a superior patria than that of the United States. ${ }^{296}$

Similarly, Gamio dismisses feminism as foreign to Mexico in the chapter entitled Nuestras mujeres (Our Women), with the possessive pronoun positioning women as yet another object of knowledge for this anthropologist to scrutinize. Gamio classifies women in three types: servant, feminine and feminist. ${ }^{297}$ The feminist woman exhibits a masculine behavior and is almost nonexistent in Mexico. The servant type is passive and devoted to others. Gamio notes that while not all indigenous women are servants (the pre-

${ }^{294}$ Molina Enríquez, Los grandes problemas nacionales, 271.

${ }^{295}$ Ibid.

${ }^{296}$ Ibid., 312.

${ }^{297}$ Gamio, Forjando patria, 119. 
colonial Aztecs are an example), contemporary indigenous women tend to be servants because of their social condition and the "immorality" of their families. ${ }^{298}$ The first point to make here is that in line with the mestizaje ideology, Gamio glorifies the indigenous past by depicting Aztec women as the paragon of femininity, but accords no value to the indigenous female present. Moreover, his mention of morality serves to shift the blame from the unequal social structures, which account for the dire living conditions of indigenous peoples, to the individual so that this servile type becomes a matter of personal choice, or responsibility. The third type is the feminine woman that Gamio identifies as "ideal" and that which Mexican women embody. ${ }^{299}$ The main aspect that makes the feminine woman "exceptional" is her abnegation and sacrifice for others; that her primary want is the "welfare" of her children. ${ }^{300}$ Gamio concludes with the lofty statement that Mexico will become a "great nation" because of the "strong, virile and resistant race" that the feminine woman has shaped. ${ }^{301}$

According to Gamio, the only role of Mexican women in the making of the nation is as biological reproducers and as transmitters of traditional values. Reducing women to their biological functions effectively erases their historical agency and direct involvement in the independence and revolutionary movements. Sociologist Nira Yuval-Davis observes that such gendered constructions of womanhood - as wombs, mothers and

\footnotetext{
${ }^{298}$ Ibid., 117.

${ }^{299}$ Ibid., 119.

300 Ibid., 130.

${ }^{301}$ Historian Ilene O’Malley suggests that such gendered language served to equate "political power with sexual potency and masculinity" in the post-revolutionary state, and "a corollary to the argument that women would lose their femininity if they acquired political power, equal rights, or suffrage" (The Myth of the Revolution: Hero Cults and the Institutionalization of the Mexican State, 1920-1940 [Westport, CT: Greenwood Press, Inc., 1986], 133).
} 
cultural reproducers of the nation - have often been "used as resources for national relations of domination and resistance." ${ }^{302}$ The erasure of women from history in the works of Gamio and Molina Enríquez serves to reinforce the notion that the mestizo is the one "true" leader of the Mexican nation and that the authors' own social group is the proper inheritor of this legacy.

The over-valorized representation of the mestizo, which absorbs indigenous peoples and cultures into its identity as a form of erasure in Los grandes problemas nacionales and Forjando patria, is central to the larger myth of mestizaje. Sociologist Natividad Gutiérrez describes this myth as "a creation of a structure of domination" that inflicts material and symbolic violence on subaltern groups. ${ }^{303}$ The myth is "symbolically violent" because it has become "unnoticed," "recognized as a legitimate product" and accepted as common sense; it is "just how things are." 304

\section{Conclusion}

The myth of Mexico as a homogeneous mestizo nation first imagined by intellectuals as diverse as Molina Enríquez and Gamio is a powerful one for its persistence and widespread circulation across all realms of public culture, including official institutions, such as government and universities, and in particular the expansion of museums, archaeological excavations and anthropological studies. For example, reconstructed ancient monuments and museums displaying the grandeur of the Aztec civilization, juxtaposed with everyday poverty, serve to reinforce the temporal distancing and hierarchical relations between mestizos and indigenous peoples, which frame the

\footnotetext{
302 Yuval-Davis, Gender and Nation, 116.

303 Gutiérrez Chong, "Symbolic Violence and Sexualities in the Myth Making of Mexican National Identity," 540.

${ }^{304}$ Ibid., 539.
} 
latter as no longer capable of reaching their ancestors' greatness and thus in need of help and protection. Benedict Anderson describes such technologies of representation as a "totalizing classificatory grid" that determines who and what "belong[s] here, not there." ${ }^{305}$ Moreover, this myth pervades everyday social practices to the extent that the term "Indian" is used as a racial epithet and "mejorar la raza" is a common saying, pointing to the aspiration to transcend both indigenousness and mestizo-ness. The challenge remains to destabilize mestizaje and to acknowledge that there are multiple ways of being Mexican.

${ }^{305}$ Anderson, Imagined Communities, 184. 


\section{Chapter Four}

\section{Dreaming of a Cosmic Race: José Vasconcelos and the Politics of Race}

The philosopher and educator José Vasconcelos is a central figure in the shaping of racial politics in Mexico, whose work consolidated the mestizo as the superior and universal race. In this chapter, I examine how he develops the theory of mestizaje in his essay, La raza cósmica (The Cosmic Race, 1925), and his lectures delivered in English at the University of Chicago in $1926 .{ }^{306}$ I also explore how his theory converged with the educational reform and eugenics movement of the time.

Vasconcelos emerged from the Ateneo de la Juventud (Athenaeum of Youth), a society of young Mexico City intellectuals founded in 1909 notable for its rejection of positivism. Among its members were philosopher Antonio Caso, writer Alfonso Reyes, artist Diego Rivera, architects and poets, many of whom were sponsored by the government to study art, music and literature in Europe. As historian Mary Vaughan points out, the Ateneo members initially had little to no interest in Mexico and "the social revolution brewing around them." ${ }^{, 307}$ Instead, these intellectuals were immersed in the readings and debates of the works of Henri Bergson, Friedrich Nietzsche and Arthur Schopenhauer, and sought to pursue "art for its own sake" and to create a space for "individual artistic expression." 308 The exception here was Vasconcelos, whose involvement in the Revolution dates as early as 1910, when he actively participated in the Francisco I. Madero movement against the reelection of president Porfirio Díaz. The

\footnotetext{
306 These lectures were sponsored by the Norman Wait Harris Memorial Foundation and compiled in a volume entitled Aspects of Mexican Civilization, which also included lectures by the anthropologist Manuel Gamio.

${ }^{307}$ Vaughan, The State, Education, and Social Class in Mexico, 1880-1928, 241.

${ }^{308}$ Ibid., 241-242.
} 
Ateneo developed within the context of a Latin American literary movement led by the Uruguayan essayist José Enrique Rodó, who stressed “the inherent ‘spirituality’ of Latin American culture in contrast to the materialist and scientism of the Anglo-Saxon world..."309 This dialectical opposition between Latin and Anglo cultures is a key aspect of Vasconcelos' racial theory and is discussed in detail below. Many of the Ateneo members worked in higher education and were instrumental in reinstituting humanist studies in Mexican universities.

Vasconcelos became prominent for his educational crusade. He first served as the Dean of the National Autonomous University in Mexico City from 1920 to 1921, providing the university with the still current motto, "The spirit shall speak for my race," which meant to signify the "awakening of our race after a long night of oppression." 310 Vasconcelos then founded the Ministry of Public Education in 1921, where he served a three-year tenure. Historian David Brading notes the achievements of Vasconcelos in education include the promotion of rural schooling, the provision of public libraries, the establishment of agricultural research institutes and vocational schools to train teachers, and the effort to incorporate indigenous peoples into "the national community." 311 Vasconcelos opposed permanent special and separate indigenous schooling, which he viewed as the North American educational model, and instead called for "the incorporation of the Indian, still isolated, into the Mexican family." 312 A final point to make here is that Vasconcelos launched a national cultural renaissance in music,

${ }^{309}$ Ibid., 242.

${ }^{310}$ José Vasconcelos, El desastre (2 ${ }^{\text {nd }}$ ed.) (Mexico: Fondo de Cultura Económica, 1982), 75.

${ }^{311}$ Brading, Prophecy and Myth in Mexican History, 72.

312 Vasconcelos, El desastre, 20. 
literature and the arts, ranging from folk-ballet to mural paintings. As Brading comments, Vasconcelos inspired a whole generation of intellectuals and artists to enter public service and to in turn "implement the policies of the revolutionary government." ${ }^{313}$ Well aware of his influence, Vasconcelos declared in one of his lengthy memoirs, "And in that moment...I was the government..." 314 Such grandiose statements are typical of his writings.

The work of Vasconcelos is illuminating for it shows how the mestizaje ideology has traveled and materialized in the many projects of national consolidation, and why it has proved resilient. Latin American and Latino Studies scholar Ilan Stavans points out, for example, how the concept of the cosmic race, which positioned the mestizo as the "leader in a new world order," became gospel for students in Mexico and the Chicano movement (which took "La Raza" as its slogan) ${ }^{315}$ in the United States during the political upheaval of the 1960s. ${ }^{316}$ Similarly, historian Nancy Stepan argues that the idea of the cosmic race "has tended to be taken at face value" and has thus "proved highly resistant to demythologization." 317 The goal of this chapter is to critically explore Vasconcelos' racial thought and its implications within the sociopolitical context. The first section of the chapter examines the emergence of the Mexican eugenics movement

${ }^{313}$ Brading, Prophecy and Myth in Mexican History, 72.

${ }^{314}$ Vasconcelos, El desastre, 12.

315 Ilan Stavans, José Vasconcelos: The Prophet of Race (New Brunswick, NJ: Rutgers University Press, 2001), 41-42.

${ }^{316}$ A bilingual edition of the book was published by the Department of Chicano Studies at the California State University in Los Angeles in 1979 and was reprinted by the Johns Hopkins University Press in 1997.

317 Stepan, The Hour of Eugenics, 149. 
in the 1930s. ${ }^{318}$ The second part looks at the educational reform and its relation to eugenics, with a focus on El Maestro (The Teacher) magazine, which was launched by Vasconcelos and delivered gratis to the public. The final section provides an analysis of La raza cósmica and the lecture entitled "The Race Problem in Latin America." The aim here is to investigate how Vasconcelos' ideas on race mixture begin to take shape and to operate within the culture at large.

\section{Eugenics in Mexico}

Eugenics was a scientific and social movement worldwide based on hereditarianism, which involved a set of policy proposals to encourage the reproduction of "fit" individuals and restrain those deemed "unfit" in order to achieve the goal of "better breeding." British scientist Francis Galton defined eugenics (from the Greek eugenes, meaning "wellborn") as "the science which deals with all influences that improve the inborn qualities of a race; also with those that develop them to the utmost advantage." 319 Similarly, in 1911, leading American eugenicist Charles Davenport described eugenics as "the science of the improvement of the human race by better breeding." ${ }^{320}$ Stern and other scholars note that while eugenics tends to be associated with the horrors of Nazism, it did not disappear after World War II. Eugenics was repackaged

${ }^{318}$ In this section, I draw primarily from the works of historians Alexandra Stern and Stepan, who are among the few US-based academics to have underscored that eugenics was intimately linked to nationalism, race and gender in Latin America. I also rely on the works of Mexican scholars, such as Marta Saade Granados, Laura Suárez and Ernesto Aréchiga Córdoba, who have contributed to recovering the history of eugenics as integral to the period of nation formation in Mexico.

${ }^{319}$ Francis Galton, "Eugenics," The American Journal of Sociology, 1 (1904), accessed September 20, 2015, http://galton.org/essays/1900-1911/galton-1904-am-journ-soceugenics-scope-aims.htm.

${ }^{320}$ Quoted in Alexandra M. Stern, Eugenic Nation: Faults and Frontiers of Better Breeding in Modern America (Berkeley and Los Angeles, CA: University of California Press, 2005), 11. 
in various forms, such as family planning, population control, genetic and marital counseling, and standardized testing. ${ }^{321}$ Moreover, eugenics was not the exclusive domain of extremists, but was rather a heterogeneous movement that involved wellrespected scientists, anthropologists, social activists, feminists, scholars, politicians and many others, ${ }^{322}$ all of whom shared "faith in the application of biology and medicine to the perceived problems of modern society." ${ }^{\prime 323}$

Latin American eugenics emerged in the last decades of the nineteenth century as part of the debates about evolution, nationalism, progress and modernity. Stepan points out that Latin America, often ignored, is an interesting case study because it was not only receptive to European science, values and ideas, but was the only postcolonial region where eugenics was developed in a more or less systematic way, with specific eugenic societies and organizations established after World War I. ${ }^{324}$ Furthermore, while most eugenicists located in the US and the UK regarded Latin Americans as "tropical," "backward," racially "degenerate" and not eugenic enough, Latin Americans nonetheless carried out their own eugenic activities. ${ }^{325}$ How was eugenics then interpreted in a context where mestizo, African and indigenous peoples predominated? What form did

${ }^{321}$ Clyde Chitty, Eugenics, Race and Intelligence in Education (London: Continuum Books, 2007). Wendy Kline, Building a Better Race: Gender, Sexuality, and Eugenics from the Turn of the Century to the Baby Boom (Berkeley and Los Angeles: University of California Press, 2001). Rebecca M. Kluchin, Fit to be Tied: Sterilization and Reproductive Rights in America, 1950-1980 (New Brunswick, NJ: Rutgers University Press, 2009). Marta Saade Granados, " ¿Quiénes deben procrear? Los medicos eugenistas bajo el signo social (México, 1931-1940)," Cuicuilco Nueva Epoca, 11 (2004): 1-36.

${ }^{322}$ For example, historian Rebecca Kluchin notes that by the 1930s there were over 300 colleges and universities in the United States that offered a course in eugenics, thus further endorsing eugenics as a "fact" (Fit to be Tied, 13).

${ }^{323}$ Stern, Eugenic Nation, 6.

${ }^{324}$ Stepan, The Hour of Eugenics, 2.

${ }^{325}$ Ibid., 8. 
eugenics take? How did it influence the politics of national identity? What implications did it have in policy and practice?

Eugenics in Mexico emerged amid the countless deaths and displacements caused by the Revolution (1910-1917), the growing problems of poverty and sickness, and a renewed sense of nationalism sponsored by the state. As Stepan comments, the Revolution's socialism and anticlericism made Mexico ideologically "receptive to new developments in science and social thought. ${ }^{326}$ Eugenics responded to a long-standing debate about how to integrate indigenous populations into the national community and how to improve the health of the poor. Hispanic Studies scholar Patience Schell notes that eugenics materialized in an array of ambitious health and social policy programs. ${ }^{327}$ For example, in 1917, the law of family relations that legalized divorce stipulated in Darwinian terms that marriage was to be regulated for the "benefit of the species." The law sought to prevent marriages among alcoholics and those with venereal diseases and tuberculosis, which were perceived to be contagious and hereditary. The reproduction of such people was framed as "detrimental to the nation, whose vigor depends on the strength of its children, as well as detrimental to the same species, which in order to perfect itself needs... a sane and prudent artificial selection aimed at mitigating the rigidity of natural selection" (emphasis in original). ${ }^{328}$ An aspect to note here is that the language of vigor, denoting good health, strength and energy (from the Latin vigere, meaning to "be lively"), is a recurring trope in the discourse of eugenics and in the

\footnotetext{
${ }^{326}$ Ibid., 55.

${ }^{327}$ Patience A. Schell, "Eugenics Policy and Practice in Cuba, Puerto Rico, and Mexico," in The Oxford Handbook of the History of Eugenics, ed. Alison Bashford and Philippa Levine (New York and Oxford: Oxford University Press, 2010), 477-492.

${ }^{328}$ Quoted in Laura Suárez, "La influencia de la sociedad eugénica mexicana en la educación y en la medicina social," Asclepio, 2 (1999): 55.
} 
writings of Vasconcelos, who imagined that the hybrid subject was to become the strongest of all races. Moreover, the law highlights the belief to which Mexican eugenicists adhered that direct intervention in the environment and education of the public would help improve the national race.

Eugenics contributed to the public health, education and welfare policies of the Mexican state well into the 1930s, focusing especially on maternal and infant hygiene programs (usually known as puériculture) ${ }^{329}$ Managing women and their reproductive choices was of particular concern to the state because they were perceived to be integral to the development of the nation. In fact, in the mid-1930s, the Department of Public Health declared, "every woman living in the territory of the Mexican Republic...has the duty to contribute within the law and according to the principles of eugenics, to fomenting a strong and healthy populace." ${ }^{330}$ Moreover, the First Mexican Congress of the Child, held in Mexico City in 1921, discussed issues of maternal health and narrowly approved the forced sterilization of criminals. Schell observes that many of the conclusions reached at the first and second (1923) child congress were implemented through the School Hygiene Service, under the Ministry of Public Education's

\footnotetext{
${ }^{329}$ Stepan explains that because of cultural and linguistic affinities, many of the biological ideas on which Latin Americans relied came from France. Of considerable influence was the naturalist Jean-Baptiste de Lamarck, who posited that acquired characteristics could be inherited. Neo-Lamarckism was embraced because it "often came tinged with an optimistic expectation that reforms of the social milieu would result in permanent improvement" (The Hour of Eugenics, 73).

${ }^{330}$ Quoted in Stern, "Responsible Mothers and Normal Children: Eugenics, Nationalism, and Welfare in Post-Revolutionary Mexico, 1920-1940," Journal of Historical Sociology, 12 (1999): 375.
} 
Department of Psycho-Pedagogy and Hygiene, whose objective was to improve the overall health of Mexican children. ${ }^{331}$

The eugenics movement in Mexico became more institutionalized with the establishment of the Mexican Eugenics Society for the Betterment of the Race in 1931. Among its members were five women involved in pedagogy, medicine, hygiene and the feminist movement, and 15 men of various professions, including politicians, criminologists, scientists, doctors and others, many of whom had been active in public health campaigns, in the Mexican Puericulture Society and in official institutions, such as the Ministry of Public Education. ${ }^{332}$ Schell points out that one of the organization's main goals was to disseminate eugenics to the public at large. To achieve this, it offered courses on reproductive health to nurses and social workers, promoted sex education courses, collaborated with the government to create radio propaganda against alcoholism, venereal diseases and prostitution, and published its own journal, named Eugenics, which ran from 1931 to 1954 , as well as books, brochures and magazines. ${ }^{333}$

The Mexican Eugenics Society also supported sterilization laws, in part because these were viewed favorably by the leading eugenic countries, such as the US, Sweden and Norway. ${ }^{334}$ In 1932, the anticlerical and socialist governor of the state of Veracruz, ${ }^{335}$

\footnotetext{
${ }^{331}$ Schell, "Eugenics Policy and Practice in Cuba, Puerto Rico, and Mexico," 485.

${ }^{332}$ Saade Granados, “¿Quiénes deben procrear?” 17.

${ }^{333}$ Schell, "Eugenics Policy and Practice in Cuba, Puerto Rico, and Mexico," 485. ${ }^{334}$ Stepan, The Hour of Eugenics, 131.

335 Stern documents that Veracruz had a "long-standing interest in improving hygiene and combating disease." The state's leaders directly collaborated with the Rockefeller Foundation in the 1920s on everything from eradicating yellow fever and hookworm to promoting healthy baby contests. Such contests insisted on the moral duty of Mexican women to produce a strong and healthy race ("The Hour of Eugenics" in Veracruz, Mexico: Radical Politics, Public Health, and Latin America's Only Sterilization Law," Hispanic American Historical Review, 91 [2011]: 436).
} 
Adalberto Tejeda, authorized the only eugenic sterilization law in the country.

Considered a "protective measure in the interest not only of the species and the race, but also beneficial for the home," this sterilization law became a central component of the governor's "multipronged reform," but received strong opposition from the elite and the traditional middle-class of Veracruz. ${ }^{336}$ Stepan notes that the law introduced sex education in schools, legalized birth control, made the registration and treatment of venereal diseases mandatory, and banned the sale of alcohol. According to an article published on the Eugenics journal regarding the law, birth control was legalized to curtail the excessive reproduction of the lower, "less desirable" classes, who threatened to degenerate the Mexican race. ${ }^{337}$ In other words, universal access to birth control was framed as a means to achieve eugenic improvement. Finally, the law legalized sterilization in "clear cases of idiocy" and for the "degenerate mad," the "incurably ill" and "delinquents." ${ }^{338}$ Stepan argues that because the law in Veracruz passed during a moment of crisis (such as the conflict between radicals and conservatives and the peasant revolt), it is unlikely that any actual sterilization took place. Moreover, as early as 1933, the Mexican Eugenics Society began to debate the limits of eugenic sterilization.

The eugenics movement in Mexico is further interesting for its inextricable relation to the racial ideologies of the time and the projects of nation formation. Mexican intellectuals had to contend with the issue of what it meant to be racially mixed at a time when the hybrid subject was almost universally condemned as degenerate and not

\footnotetext{
336 Ibid., 431.

${ }^{337}$ Stepan, The Hour of Eugenics, 132.

338 Ibid.
} 
eugenic. ${ }^{339}$ They pondered whether mixing could produce beneficial results and whether it should be encouraged as a process of national consolidation. Vasconcelos was one of the first Mexican intellectuals to reformulate the dominant notion of hybridity in La raza cósmica in order to argue that mixing, in fact, could produce superior beings. Stepan shows that the tendency to counter European racial science with "mythologies of their own" began in Mexico well before the Revolution, especially during the days of Porfirio Díaz. ${ }^{340}$ For example, positivist thinker and educator Justo Sierra rejected the "excessively negative" views about hybridity that the likes of Gustave Le Bon endorsed and "replace[d] them with more positive views of the mestizo as the dynamic element in national life." ${ }^{341}$ However, it was the Revolution that brought about "the full development of counterracial mythologies." ${ }^{342}$ For example, the 1920s saw the rise of the discourse of indigenismo, which celebrated indigenous peoples on a purely symbolic level, with no real commitment to social reform. This discourse led to anthropological studies of indigenous groups, archeological excavations of pre-Columbian monuments, and the romanticization of indigenous peoples in art and literature. But it was the mestizo that was to become the one and only protagonist of the Mexican nation and mestizaje the official ideology of the state.

\footnotetext{
${ }^{339}$ Postcolonial theorist Robert Young notes that Latin America was always cited in the works of British intellectuals "as the prime example of the degenerative results of racial hybridization." For example, ethnologist Robert Knox blamed the chronic instability and revolutions of Latin America on its race mixture, which he described as "a disgrace to human nature" (Colonial Desire: Hybridity in Theory, Culture and Race [London and New York: Routledge, 1995], 175).

${ }^{340}$ Stepan, The Hour of Eugenics, 145.

${ }^{341}$ Ibid.

${ }^{342}$ Ibid., 146.
} 
The members of the Mexican Eugenics Society viewed indigenous peoples as an object of redemption that needed to be incorporated into the nation. In this way, heterogeneity could be eliminated and the Europeanized mestizo could rise. Indigenous peoples were only accepted in this vision of the nation to the extent that they adapted to modernity and adopted the dominant way of life. Moreover, many eugenicists opposed immigration of non-white populations on the grounds that they would complicate the process of racial fusion and national unification. Eugenicists were particularly against black people, Jewish people, Chinese people and Syrians because they were perceived to be "unassimilable" and incompatible to the Mexican character, and "would therefore cause further fragmentation of the nation." 343 Black people were especially targeted because they were seen as "racially inferior," "occupationally incompetent" and "dangerous to the national indigenous population." 344 The reasoning against black immigration, debated in numerous confidential official documents and supported by intellectuals and civil servants, was that in Mexico's nation-building model, "the mestizo is not colored." 345 On the other hand, doctor Rafael Carrillo and other eugenicists argued that the Mexican state should give preference to white immigration because it was established that "the white race, especially the European Nordic race, possesses the highest values according to Galton's scale." 346 This hierarchical language of high and low

\footnotetext{
343 Ibid., 153.

${ }^{344}$ Marta Saade Granados, "Una raza prohibida: Afroestadounidenses en México," in Nación y extranjería: La exclusión racial en las políticas migratorias de Argentina, Brasil, Cuba y México, ed. Pablo Yankelevich (Mexico: Universidad Nacional Autónoma de México, 2010), 237-238.

345 Ibid., 246.

${ }^{346}$ Quoted in Suárez, "La influencia de la sociedad eugénica mexicana en la educación y en la medicina social," 73. It is worth noting that Mexico at the time recorded one of the lowest immigration rates in Latin America. For example, between 1928 and 1932,
} 
helped create an "Other" that was both racialized and classed, thereby legitimizing the regulation of indigenous peoples, peasants and the urban poor in Mexico. However, eugenicists' activities also revealed a profound anxiety over the impossibility of realizing the dream of a cosmic race. As Stepan concludes, mestizaje was not so much a reality as a myth of national unity that served to obscure "the very real cultural, social, class, and political divisions of Mexican society." ${ }^{347}$

Mexican eugenics in the 1940s developed into biotypology, or the theory of human differentiation. The objective of this theory was to classify people into "biotypes" according to the seemingly neutral categories of normal, average and median, which left an imprint on the disciplines of anthropology, sociology and criminology. ${ }^{348}$ Although eugenics remained mainly at the level of prescription, it had a significant impact across all aspects of society because it produced a series of medical expectations and moral codes about who the Mexican citizen should be and how she/he should behave. In the next section, I explore the overlap between Vasconcelos' educational crusade and the eugenics movement in terms of their ideas, concerns and aims to modernize the Mexican people.

\section{Educational Reform}

During his tenure as Dean of the National University, Vasconcelos devised the proposal that would result in the creation of the Ministry of Public Education (SEP in its

immigrants did not exceed 0.1 percent of the total national population (Pablo Yankelevich and Paola Chenillo Alazraki, "La arquitectura de la política de inmigración en México," in Nación y extranjería: La exclusión racial en las políticas migratorias de Argentina, Brasil, Cuba y México, ed. Pablo Yankelevich [Mexico: UNAM], 209).

${ }^{347}$ Stepan, The Hour of Eugenics, 151.

${ }^{348}$ Stern, Mestizophilia, Biotypology, and Eugenics in Post-Revolutionary Mexico: Towards a History of Science and the State, 1920-1960 (Chicago, IL: Center for Latin American Studies, University of Chicago), 2. 
Spanish acronym). The proposal called for the constitutional reform of Articles 14 and 73 that would allow the federalization of the school system. The reform passed the House in February 1921 and the Senate shortly thereafter. ${ }^{349}$ Vasconcelos then traveled to various states to rally support for his legislation. Vaughan notes that on these trips, Vasconcelos took with him Mexico City intellectuals and artists who performed their art at gatherings to win over state officials, teachers and other members of the middle class. The SEP officially came into being in October 1921, with Vasconcelos as its first minister.

The SEP was divided into three general sections: schools, libraries and the fine arts. The Department of Schools was responsible for all primary, secondary, technical and rural schooling, as well as for school hygiene and medical inspection. ${ }^{350}$ Historian Aréchiga Córdoba observes that the educational campaigns and propaganda on hygiene instituted by the SEP and the Department of Public Health became ubiquitous between 1917 and 1934, and were central to "the civilizing discourse that the state and dominant classes adopted" after the Revolution. ${ }^{351}$ The gospel of cleanliness was imagined to bring about the "regeneration" and "redemption" of the popular classes, conceived as indolent and ignorant, and in turn justified their increased surveillance. ${ }^{352}$ The state's concerted efforts to teach, improve and modify the population's hygienic habits can also be viewed

\footnotetext{
${ }^{349}$ Vaughan, The State, Education, and Social Class in Mexico, 1880-1928, 135. ${ }^{350}$ Ibid., 136.

${ }^{351}$ Ernesto Aréchiga Córdoba, "Educación, propaganda o 'dictadura sanitaria:' Estrategias discursivas de higiene y salubridad pública en el México posrevolucionario, 1917-1945," Estudios de Historia Moderna y Contemporánea de México, 33 (2007): 59. ${ }^{352}$ Katherine Bliss, "For the Health of the Nation: Gender and the Cultural Politics of Social Hygiene in Revolutionary Mexico," in The Eagle and the Virgin: Nation and Cultural Revolution in Mexico, 1920-1940, ed. Mary K. Vaughan and Stephen E. Lewis (Durham and London: Duke University Press, 2006), 196-218.
} 
as part of the elite's larger concern to transform Mexico into a modern and civilized nation.

The Department of Libraries helped create thousands of small libraries and publish cheap editions of European and Mexican literature, with the aim of inculcating in the public the habit of reading. The Department of Fine Arts for its part became "the center of a cultural renaissance in music, the plastic arts, and literature." ${ }^{353}$ The Literacy Campaign $^{354}$ and the Department of Indigenous Culture were also established, but only as provisional and independent departments. Vasconcelos mentions in one of his memoirs that the Indigenous Department was meant to follow the action of the early Christian missionary in order to teach indigenous peoples Spanish and to incorporate them into the nation. ${ }^{355}$ Such an elitist attitude was further reflected in his crusade to publish the European classics in a country that was largely illiterate. In the same memoir, for example, he states, "What this country needs is to start reading The Iliad. I will distribute thousands of Homers in national schools and libraries..." ${ }^{356}$ For him, it was necessary that the public learned "in our language...the essential ideas of all times." 357 Vasconcelos here reveals that his educational plan was to remain a paternalistic effort more interested in civilizing the masses than in offering real structural reform.

\footnotetext{
${ }^{353}$ Vaughan, The State, Education, and Social Class in Mexico, 1880-1928, 136.

${ }^{354}$ Aréchiga Córdoba points out that when Vasconcelos launched the Literacy Campaign in 1920, he emphasized that acquiring hygienic habits was necessary to achieve successful literacy rates. Vasconcelos further recommended teachers to begin their courses by addressing the topic of personal hygiene, a healthy diet and so on ("Educación, propaganda o 'dictadura sanitaria,"” 78).

355 Vasconcelos, El desastre, 20.

356 Ibid., 46.

357 Ibid., 48.
} 
A central aspect of the SEP was rural education. Under the Department of Indigenous Culture, so-called "missionary" teachers traveled to rural areas "to interest communities in education and to recruit teachers locally"358 To assist teachers in their training, the SEP created regional rural normal schools and offered courses in agriculture, crafts, sports, hygiene and pedagogy. In addition, it distributed pamphlets, periodicals, instructional manuals and other publications. Vaughan observes that there was a deep ideological divide between rural and urban educators. While the former was committed to social reform, the latter tended to "view education as disciplining, civilizing, and controlling." 359 Urban educators were more conservative in their approach to schooling in part because of their previous involvement in the Porfirian school bureaucracy, their middle-class background and "their lack of identification with the popular revolution." 360 The top officials who dictated rural education programs had the belief that peasants were backward and isolated, but could be redeemed and transformed into "a productive unit within the nation." 361 As such, education emphasized skill training and the introduction of modern agricultural methods and tools. For rural teachers, however, the SEP's efforts seemed naïve because they ignored the fact that structural changes were needed in order to significantly improve the lives of peasants.

The urban educators' personal and class biases are in full display in the SEP magazine El Maestro (see Appendix A). ${ }^{362}$ Vasconcelos introduces the first volume by

\footnotetext{
358 Vaughan, The State, Education, and Social Class in Mexico, 1880-1928, 138.

359 Ibid., 143.

${ }^{360}$ Ibid., 142.

${ }^{361}$ Ibid., 145.

${ }^{362}$ For example, the cover image of the first issue features a white woman draped in Western garb (reminiscent of classical Greek sculpture) holding an open book. The image underlines the elitist view that education could function as a civilizing agent.
} 
stating that the purpose of the magazine is "to disseminate practical knowledge among the country's population." ${ }^{\prime 363} \mathrm{He}$ notes that the magazine will be distributed gratis precisely because it is meant for the general public. However, it is clear that his five-page introduction addresses one particular group of people and not all - that of intellectuals. Vasconcelos critiques his colleagues for their lack of action and indifference toward the people, and rallies them to become involved in his educational crusade. In his characteristic grandiose speech, Vasconcelos declares, "[the masses] will become a ruinous burden if we abandon them, if we maintain them ignorant and poor, but if we educate them and make them strong, their strength merged into ours will make us invincible. ${ }^{364}$ From his point of view, the intellectual is the only one capable of leading the Mexican nation toward modernity and into the world stage. In a similar vein, Vasconcelos explains that the content of the magazine will not be what people want but what they need, with "the continuous purpose of elevating them.." ${ }^{365}$ Note the use of the word "elevate," meaning to raise to a higher position - this high and low distinction frames the racialized and classed "Others" as needing to be brought into civilization by the intellectual. ${ }^{366}$ Moreover, the fact that the intellectual gets to decide what is in people's best interest effectively denies the latter any agency. Throughout the first volume of the magazine are articles by authors as varied as French novelist Romain

\footnotetext{
${ }^{363}$ Vasconcelos, “Un llamado cordial,” in El Maestro, 1 (1921): 5. ${ }^{364}$ Ibid., 7.

${ }^{366}$ Cinema studies scholars Ella Shohat and Robert Stam observe that the spatial tropes of high and low, which pervade Vasconcelos' writings, are not neutral or innocent of power, for these always "devolve into symbolic hierarchies that simultaneously embrace class (the 'lower class'), esthetics ('high' culture), the body (the 'lower bodily stratum'), zoology ('lower' species), and the mind (the 'higher and lower' faculties)" (Unthinking Eurocentrism, 140).
} 
Rolland, Irish writer George Bernard Shaw and the Russian novelist Leo Tolstoy, which serve to highlight Vasconcelos' aspiration that through European literature the Mexican people could become civilized.

The first issue of El Maestro is divided into six sections: News, Educational Talks, Social Recommendations, Literature and Art, Practical Knowledge and the children's section, Aladdin, penned exclusively by the Mexican educator Rosaura Zapata. The practical knowledge part, written on a more didactic tone, is of particular interest here for its focus on health, hygiene and the home. For example, the magazine warns of the dangers of narcotics and discusses how to maintain an "attractive dining room" (e.g. sunlight, fresh flowers, paintings on the wall, etc.) in order to cultivate the happiness of the family. In this section, there is a short article entitled "Organization of the family at home," written by the teacher Estefanía Castañeda, who dedicated herself to developing kindergarten education in Mexico. Much like eugenicists, Castañeda views women as mothers of the nation: "[their role] is to lead the family, to create a new race that must live forever..." (emphasis in original) ${ }^{367}$ She laments that women are not fulfilling this role because of their lack of education when it comes to motherhood. If they were to be educated, she continues, they would be able to establish a proper home and in turn, to foment happiness and harmony at large. ${ }^{368}$ The sentiments expressed in this article reflect the "notion of responsible motherhood," as Stern calls it, that the Mexican state introduced in the 1920s. The health of the family became the individual responsibility of

${ }^{367}$ Estefanía Castañeda, “Organización familiar en la casa," El Maestro, 1 (1921): 73-74. ${ }^{368}$ Ibid., 75. 
the mother, whose rearing practices and activities at home were monitored and tied to the nation's need to create a healthy and strong mestizo race. ${ }^{369}$

The practical knowledge section is further interesting for its focus on the rural population and its way of life. For example, the first volume offers information about domestic animals and how to take care of them in terms of diet and hygiene. Moreover, it explains the uses of modern agricultural machinery and recommends that older methods of agriculture be substituted with this machinery in order to cultivate more land. ${ }^{370}$ The article also posits that modern machinery will allow peasants to enjoy leisure time and to forge a "social life, which is indispensable for the formation of a nation... [but] it is nonexistent when one lives in the countryside." ${ }^{371}$ The author perpetuates the dominant view that peasants are isolated and need to be integrated into the national whole. As Vaughan argues, many of the SEP's efforts in rural areas ignored that peasants were not so much isolated from the market economy but "were marginalized within it by their meager land resources, technology, and exploitative market relationships." ${ }^{372}$ Although Martínez emphasizes the need for new technology, he places the responsibility of material improvement on the individual peasant and her or his capacity to not only increase work productivity but to strengthen social relations.

Browsing through El Maestro magazine is a fascinating activity for the almost random manner in which it seems to have been assembled. The second issue, for example, begins with an educational article on how the earth came into being and is followed by everything from a French intellectual manifesto to Tolstoy's dry writing to

${ }^{369}$ Stern, "Responsible Mothers and Normal Children," 375.

${ }^{370}$ Ernesto Martínez de Alva, “La vida del campo,” El Maestro, 1 (1921): 80.

${ }^{371}$ Ibid.

${ }^{372}$ Vaughan, The State, Education, and Social Class in Mexico, 1880-1928, 144. 
the practical knowledge section, which encourages vegetarianism and praises Las tribus indígenas mexicanas (akin to the boy scouts) as patriotic, to poetry and literature, all interspersed with pictures of the School of Fine Arts in Mexico City. One striking article is "Universal History" by American journalist William Swinton, who makes no effort to hide his racism. He defines history as the study of nations, "that is, man in civilization" (emphasis in original). ${ }^{373} \mathrm{He}$ argues that Caucasians are the only race that can be called historical and therefor "we can say that civilization is the product of this race." $374 \mathrm{He}$ mentions that Mexicans, Peruvians and Chinese people played a role in civilization, but "their civilizations remained stuck." 375 The use of the adjective "stuck," which denotes the inability to move or to progress, is convenient because it positions non-Anglo cultures in the past, as existing outside of history and modernity. Immediately following this sixpage piece is "History of Mexico," which challenges Swinton's white supremacist fantasies. The author extols pre-Columbian societies like the Aztecs and affirms, "If our past is full of grandeur, then we have no right to doubt our future." ${ }^{376}$ These two opposing articles and the magazine in general point to the confusion and ambivalence Mexican intellectuals felt toward their country and its predominant mestizo and indigenous populations. As discussed below, Vasconcelos viewed the mestizo as rising to the status of a cosmic race as long as he became that which he was not: Europeanized, educated and cultured.

One final aspect to note here is that Vasconcelos' influence extended to the cultural nationalist movement, which nationalized popular and indigenous culture and

${ }^{373}$ William Swinton, "Historia universal," El Maestro, 1 (1921): 118.

${ }^{374}$ Ibid.

375 Ibid.

${ }^{376}$ Rafael Ramos Pedrueza, “Historia mexicana,” El Maestro, 1 (1921): 123. 
thus helped define a common notion of mexicanidad. A central component of the movement was mural art led by the likes of Diego Rivera. Although Vasconcelos oftentimes complained that Rivera painted too many indigenous peoples and brown peasants, and wanted subjects like The Iliad to be represented, he defended and sponsored the mural movement in part because he viewed art as the highest mark of civilization and because he wanted to promote Mexican artists on an international scale. ${ }^{377}$ Vaughan contends that muralism was as contradictory as the SEP's endeavors because while it made mestizo and indigenous peoples the protagonists of the Revolution, and aligned with their aspirations and ideals, it also obfuscated class conflicts and the unequal power structures. For many intellectuals like Vasconcelos, art could be used as a mechanism of social control over those who needed to be civilized. ${ }^{378}$ Having developed the sociopolitical context that Vasconcelos navigated, I now proceed to analyze his own written work.

\section{The Cosmic Race}

The central thesis of La raza cósmica is that the accelerated mixing of the world's races will pave the way for the emergence of a new type of people, that is, the "future Cosmic Race. ${ }^{379}$ In the prologue, Vasconcelos questions whether such mixing can benefit or hamper the growth of culture. He asks, "can the mestizo's contribution to culture be comparable to that of the relatively pure races that have made history until

377 Vaughan, Cultural Politics in Revolution: Teachers, Peasants, and Schools in Mexico, 1930-1940 (Tucson, AZ: The University of Arizona Press, 1997).

378 Ibid., 265.

${ }^{379}$ Vasconcelos, La raza cósmica, (2 ${ }^{\text {nd }}$ ed.) (Baltimore, MD: Johns Hopkins University Press, 1997), 43. 
now, such as the Greeks, Romans or Europeans?" ${ }^{380}$ He briefly mentions that while in such powerful civilizations as ancient Greece and the US mixing has occurred among similar European races, mestizaje in Latin America has developed among "distant types," mainly Spaniards and indigenous peoples, which accounts for its "underdevelopment."381 But Vasconcelos remains optimistic and concludes this section of the book by affirming, "even the most contradictory mestizajes can have beneficial results as long as the spiritual factor contributes to raise them. In fact, the decline of Asiatic peoples can be attributed to their isolation, but also, and without doubt, to the fact that they have not been Christianized. A religion such as Christianity made the American Indians advance, in a few centuries, from cannibalism to a relative degree of civilization.. ${ }^{382}$ The first aspect to note here is that Vasconcelos redeems the figure of the mestizo only at the expense of other groups, particularly Asians, whom he continually denigrates. Second, Vasconcelos frames religion as a civilizing agent, as a gift that can improve the seemingly backward condition of the natives. Third, he perpetuates the stereotypical view that Latin American nations are "new" and need to play catch up with Western modernity to enter the world stage.

The first part of La raza cósmica entitled "Mestizaje" recounts the myth of the rise and fall of Atlantis in the American continent to highlight that races appear and disappear after fulfilling their mission and are then replaced by others. Vasconcelos notes that at the current moment the white race has become the "world's invader," but its

\footnotetext{
380 Ibid., 43-44.

${ }^{381}$ Ibid., 45.

382 Ibid., 45.
} 
"predominance will surely also be temporal." ${ }^{383} \mathrm{He}$ observes that the mission of whites, begun with the colonization of the Americas, is to "serve as the bridge" that brings together and unifies all other races into one, into "a fifth universal race" that is to be totalizing and superior to all earlier races. ${ }^{384}$

Vasconcelos views Latin America as the chosen land ripe for the development of the fifth race because of its greater "openness to strangers" $" 385$ and for its ability to assimilate the distinct races that the Anglo nations exterminated. ${ }^{386}$ He praises the Spanish colonizers and their "abundance of love that allowed [them] to create a new race with the Indian and the Black." ${ }^{387}$ In contrast, he argues that the English refusal to mix with other races points to their inevitable decay because "the ultimate aim of History is to achieve a fusion of all peoples and all cultures. ${ }^{3388}$ Such statements are convenient because they frame racism as existing elsewhere (in those homogeneous white nations) and as in opposition to the tolerant nature of Latin America. However, Vasconcelos reveals that the love for others is not equally distributed. For example, in his critique of

\footnotetext{
383 Ibid., 49.

${ }^{384}$ Ibid.

${ }^{385}$ Latin America is conceived as a hospitable place in two different ways. The first follows the narrative of the nation as a generous host offering hospitality to its guests. As postcolonialist scholar Ali Behdad observes, this narrative is often mobilized "to mask the exclusionary and regulatory practices of immigration" (A Forgetful Nation: On Immigration and Cultural Identity in the United States [Durham and London: Duke University Press, 2005], 22). Furthermore, Vasconcelos frames Latin America as hospitable in terms of its environment (fertile lands, abundant natural resources and warm climate) in order to counter the European racial theories of the time, which posited tropical regions as conducive to degeneracy and a weak character. In fact, Vasconcelos argues that the environment of Latin America is an advantage to the rise of the mestizo: "The great civilizations of the past arose in the tropics and the final civilization will return to the tropics" (La raza cósmica, 63).

386 Ibid., 57.

387 Ibid.

388 Ibid., 58.
} 
the US and its strict immigration laws, he concedes that borders must be protected when it comes to "economic competition" and to reducing the large influx of the Chinese population. ${ }^{389}$ For example, Vasconcelos states in eugenic terms, "[It is] unjust that peoples like the Chinese, who under the pious guidance of Confucian morality multiply like rabbits, should come to degrade the human condition just as we are beginning to understand that intelligence can rein in and regulate our base animal instincts...If we reject them, it is because as man progresses, his rate of reproduction decreases and he feels a horror of quantity, precisely because he has come to esteem quality." ${ }^{390}$ In this passage, the racism that had been lurking in the background becomes explicit and reflects the larger xenophobic attitudes that predominated at the time in Mexico regarding "undesirable" immigrants, such as the seemingly over-reproductive Chinese, who were systematically oppressed and excluded in the northern states.

According to Jason Oliver Chang and other scholars, mestizo nationalism and antichinismo (or anti-Chinese racism) went hand in hand in the 1930s. ${ }^{391}$ The construction of an idealized mestizo Mexican nation required the erasure of the Chinese population. The systematic forgetting of the Chinese population became "an imperfect mechanism to obfuscate the racist underpinnings" of the post-revolutionary state and its

\footnotetext{
389 Ibid., 59.

390 Ibid., 59-60.

391 Jason Chang, Chino: Anti-Chinese Racism in Mexico, 1880-1940 (Champaign, IL: The University of Illinois Press, 2017). Grace Peña Delgado, Making the Chinese Mexican (Palo Alto, CA: Stanford University Press, 2012). Robert Chao Romero, The Chinese in Mexico, 1882-1940 (Tucson, AZ: The University of Arizona Press, 2010). Gerardo Rénique, "Race, Region, and Nation: Sonora's Anti-Chinese Racism and Mexico's Postrevolutionary Nationalism, 1920s-1930s," in Race and Nation in Latin America, ed. Nancy Appelbaum (Chapel Hill, NC: The University of North Carolina Press, 2003), 211-236.
} 
efforts to realize its vision of a homogeneous mestizo Mexico. ${ }^{392}$ The image of the mestizo as the "true Mexican" was thus pitted against the Chinese, who were framed as being sources of vice, immorality, diseases, racial degeneracy and economic stagnation. Such negative depiction of Chinese people served to justify the violence perpetrated against them and their subsequent expulsion from the country. Moreover, as discussed above, managing women became a central concern of the Mexican state because they were perceived to be integral in the reproduction of a strong Mexican nation. As such, women who were engaged in marital and/or sexual unions with Chinese men could be revoked of their Mexican citizenship because they were perceived to be race traitors and contaminators, contributing to the degeneracy of the nation. Historian Grace Peña Delgado observes that women in post-revolutionary Mexico were framed "as the moral guardians of Mexican racial purity," who were tasked with reproducing a robust and fit population through "better breeding." 393

The first section of La raza cósmica concludes with Vasconcelos reiterating the spiritual and tolerant character of Latin America vis-à-vis the cold Anglo-Saxon world. He observes that in Latin America, "we find countless bridges towards the sincere and cordial fusion of all races. The contrast between the northerners' ethnic immurement and the southerners' openness is for us the most important as well as the most favorable fact if one thinks... of the future, because it will then be immediately plain that we belong to tomorrow and they belong to yesterday." ${ }^{394}$ With such statements about the future supremacy and universality of the mestizo that serve to validate Latin American identity,

\footnotetext{
${ }^{392}$ Chang, Chino, 191.

${ }^{393}$ Peña Delgado, Making the Chinese Mexican, 112.

${ }^{394}$ Vasconcelos, La raza cósmica, 60.
} 
it is not difficult to see why La raza cósmica may have been taken as gospel by Mexican students and the Chicano movement, which struggled to achieve sociopolitical autonomy in the face of white supremacy and US cultural hegemony. However, this is a book that requires close scrutiny because it is full of contradictions that more often than not reveal the author's preference for a white and Europeanized mestizo.

The preference for whiteness is made more explicit in the second and third untitled sections of La raza cósmica. Vasconcelos here notes that while the fifth race does not exclude and makes use of the abilities of all races, "the characteristics of the white race will perhaps predominate among those of the fifth race, but such supremacy must result from free choice and taste, and not violence or economic pressure. ${ }^{״ 395}$ In Vasconcelos' view, mestizaje is a matter of aesthetics rather than necessity or propinquity, as was the case during the colonial period. He observes that the world is now entering the third stage ${ }^{396}$ in which "the laws of emotion, beauty and joy will govern the choice of partners, with results infinitely superior to those of a eugenics based in scientific reason...The mysterious eugenics of aesthetic taste will prevail over the eugenics of science." ${ }^{397}$ In this new era, ugliness and its root causes, such as "poverty, deficient education...wretchedness," will vanish. ${ }^{398}$ Vasconcelos proposes educating the "inferior races" in order to make them "less prolific," but otherwise imagines that the law of beauty will be sufficient for the rise of the cosmic race. "Step by step," he argues,

\footnotetext{
395 Ibid., 65.

396 Vasconcelos draws from Auguste Comte's "Law of Three Stages" to explain that society develops in three stages: the first is the material or military in which force prevails; the second is the intellectual or political and is ruled by reason; and the third is the spiritual or aesthetic (68).

${ }^{397}$ Ibid., 70.

398 Ibid.
} 
"[and] by voluntary extinction, the uglier stocks will give way to the more

handsome...The Indian, by grafting onto the related race, would take the jump of millions of years that separate [him] from our times, and in a few decades of aesthetic eugenics, the black may disappear..." ${ }^{399}$ In Vasconcelos' notion of mestizaje, "the Indian" must become modern, or disappear, and black people, deemed already too ugly and deficient, must simply disappear. As Ethnic Studies scholar Jared Sexton points out, the mode of eugenics in La raza cósmica takes on a different form, "but its ends remain frighteningly consistent $-\mathrm{a}$ 'selection' more efficient than a brutal Social Darwinism. Less carnage, less coercion, and less political controversy, this appears to be 'evolution' at a discount. ${ }^{" 400}$ In other words, in its efforts to integrate everyone and everything into one sort of master race, mestizaje must not only absorb the white stock but abolish those that are deemed ugly, that is, the racialized others, the uneducated, the poor. ${ }^{401}$ It is interesting to note how the apparently neutral language of beauty is in itself racialized, which equates ugliness with blackness and handsomeness with whiteness.

${ }^{399}$ Ibid., 72.

400 Jared Sexton, "The Consequences of Race Mixture: Racialised Barriers and the Politics of Desire," Journal for the Study of Race, Nation and Culture, 9 (2010): 248. ${ }^{401}$ Vasconcelos was not alone in his fantasy of an aesthetically superior race, but was shared by scientists of the time. For example, in 1921, Mexican evolutionist Alfonso L. Herrera imagined that in the near future, laboratory science would produce a "supreme beauty of form, intellect, and virtue" - a form so perfect, it would be "Hellenic" (quoted in Stepan, The Hour of Eugenics, 135). The reference to Hellenic beauty is interesting because it underscores how since the eighteenth century, dominant racial theories have deployed classical Greek art (for example, the Apollo Belvedere and its facial angle) as a standard of physical beauty and intellect (David Bindman, Ape to Apollo: Aesthetics and the Idea of Race in the Eighteenth Century [London, UK: Reaktion Books LTD, 2002]; Debbie Challis, “The Ablest Race': The Ancient Greeks in Victorian Racial Theory," in Classics and Imperialism in the British Empire, ed. Mark Bradley [New York and Oxford: Oxford University Press, 2010], 94-120). 
Many of the themes present in La raza cósmica recur in a series of lectures Vasconcelos delivered at the University of Chicago in 1926, a year after the book's publication. For example, the opposition between Latin and Anglo cultures, Christianity as a civilizing agent, mestizaje and aesthetics, ${ }^{402}$ all make an appearance. The lectures are grouped under the heading, "The Latin American Basis of Mexican Civilization," and are divided into three parts: "Similarity and Contrast," "Democracy in Latin America" and "The Race Problem in Latin America." The lectures were sponsored by the Harris Foundation, whose mission statement was "the promotion of a better understanding on the part of American citizens of the other peoples of the world, thus establishing a basis for improved international relations and a more enlightened world-order." The statement concluded, "the aim shall always be to give accurate information, not to propagate opinion." But opinion is the bread and butter of Vasconcelos' work, whose own modus operandi is described as being based on intuition and as taking "a spiritual leap, sustained by facts" 403 - this is reflected in his opaque writing style and simplistic view of history.

The lecture of interest here is "The Race Problem in Latin America" because it expands on the topic of mixture. Vasconcelos begins with the observation that North America and Latin America are essentially different because the former follows "the one race-standard," which excludes and refuses to intermarry with dissimilar stocks, as

\footnotetext{
${ }^{402}$ In his first lecture, Vasconcelos correlates physical beauty with class status: "Where there is no comfort at all, the human body turns back to the beasts. Leisure and wealth develop beauty in any racial stock" (39). Hard work and miserable living conditions are why indigenous peoples are "decidedly plain looking" and "a race of slaves cannot be beautiful" (39). For Vasconcelos, a dark face, body and skin are the visible stigma of a lower civilization that must be improved for the benefit of the nation.

${ }^{403}$ Vasconcelos, La raza cósmica, 49.
} 
against "the mixed-race standard" of the latter. ${ }^{404}$ Vasconcelos explains that this mixture produced the mestizo, who is neither indigenous nor Spanish, but a "hyphen" seeking to reconcile the conflicting personalities of his ancestors into one. Because the mestizo is "unable to connect fully with the past, [he] is always directed toward the future - is a bridge to the future." 405 Vasconcelos proceeds to acknowledge that the dominant racial theories of his time do not share his positive views on hybridity. He singles out Herbert Spencer, who posited the hybrid figure was degenerate and inferior, to note that the socalled "pure-race" theory is nothing but a myth that serves to maintain the power of the dominant people. ${ }^{406} \mathrm{He}$ inverts this theory, without disavowing the language of biology, to argue that "hybridism in man, as well as in plants, tends to produce better types and tends to rejuvenate those types that have become static. If we go through history, we find that after a period of adaptation the results of the renewal of blood are always beneficial." 407 The words "rejuvenate" and "renew," which denote the process of making something young or new again, underline Vasconcelos' optimism about hybridity's potential to produce superior racial beings.

Vasconcelos cites the Spanish method of colonization through assimilation as an example of the benefits interbreeding produces. While the English remain "completely strangers" in their colonies, he comments, "the Spanish have succeeded in reproducing their blood in part and their culture in full in twenty nations that are today as Spanish as

\footnotetext{
${ }^{404}$ Vasconcelos, "The Race Problem in Latin America," in Aspects of Mexican Civilization, ed. Manuel Gamio and José Vasconcelos (Chicago, IL: The University of Chicago Press, 1926), 80.

405 Ibid., 83. 406 Ibid., 84.

${ }^{407}$ Ibid., 85. Vasconcelos here refers to the work of anthropologist Eugène Pittard, whose own contention against the pure-race theory appeared in the book Les Races et l'Histoire in 1924.
} 
Spain itself can be..." ${ }^{408}$ In Vasconcelos' notion of mestizaje, the European side of the equation is the superior and dynamic element that is responsible for reinvigorating the "static" natives. In fact, he argues that "Latin America owes what it is to the white European and will not disavow him. ${ }^{\circ 09}$ His imagined Latin American community is a purely Europeanized one. ${ }^{410}$ Vasconcelos denies any agency to indigenous peoples and expresses ambivalence, if not outright contempt, about their contribution to culture - or lack thereof, as he asserts that "the Indian has no civilized standards upon which to fall back." $" 411$

In his conclusion, Vasconcelos cautions against relying on foreign theories because these can restrain the growth of the Latin American spirit. He notes that the only "sound race policy" for the region is "the policy of old - the policy of the Spaniard and Christian who took it for granted that we are all potentially the same and that we are bound to respond differently according to the call that is made upon us..." ${ }^{\prime 412} \mathrm{He}$ contends that there are no differences among races in terms of evolutionary development, but only differences in abilities and talents - all races are potential contributors to this new spiritual civilization. However, he quickly contradicts himself when he exhorts the "superior" stocks to "take pains to educate the inferior and to raise its standards." ${ }^{.13} \mathrm{He}$

\footnotetext{
408 Ibid., 86-87.

${ }^{409}$ Vasconcelos, La raza cósmica, 65.

410 The (over) valorization of a Europeanized culture was not uncommon among Mexico City intellectuals (see next chapter). For example, over a decade later, philosopher Samuel Ramos stated in Profile of Man and Culture in Mexico that Mexican culture could never be original because it was "European by definition... We have European blood, our language is European, our customs and morality are European, and the sum of our vices and virtues is a legacy of the Spanish race" (75).

${ }^{411}$ Vasconcelos, "The Race Problem in Latin America," 90.

412 Ibid., 98.

${ }^{413}$ Ibid., 100.
} 
continues, "if we do not wish to be overwhelmed by the wave of the Negro, of the Indian, or of the Asiatic, we shall have to see that [they] are raised to higher standards of life, where reproduction becomes regulated and quality predominates over numbers."414 Vasconcelos here reveals that in mestizaje, not all races are created equal. Note how the spatial tropes of high/low once again become racialized, positioning the "Negro," the "Indian" and the "Asiatic" as threats to the emergence of this aesthetically superior cosmic race. Moreover, Vasconcelos reproduces many of the racial theories he claims to disavow because he frames the non-white European as a subordinate subject who needs to be redeemed, or exterminated, through eugenic-related measures.

Vasconcelos' Europeanized education and middle-class biases are evident in his writings. As Vaughan remarks, Vasconcelos and other members of the Ateneo felt a profound alienation from and even "contempt for Mexican realities." ${ }^{415}$ The perceived poverty, misery and violence of Mexico were for Vasconcelos "a constant source of anguish," which he partly resolved through his interests in aesthetics and art. ${ }^{416}$ In $L a$ raza cósmica, he articulates a utopian vision of a Latin America ruled by beauty, without racism. The book glorifies Spanish culture at the expense of others that only appear as stereotypes (e.g. black people as musical and sensual, Arabs as melancholic and Asians as mysterious), ${ }^{417}$ which in turn reveals Vasconcelos' ambivalence toward the nonEuropean and his lack of knowledge of historical processes. But most important for this project is that La raza cósmica influenced the eugenics and education movements in

\footnotetext{
${ }^{414}$ Ibid., 101.

415 Vaughan, The State, Education, and Social Class in Mexico, 1880-1928, 251. 416 Ibid.

${ }^{417}$ Vasconcelos, La raza cósmica, 62.
} 
Mexico, whose main concern was to deliver on the promise of mestizaje: to improve the race (or mejorar la raza) and to in turn civilize the nation.

\section{Conclusion}

Vasconcelos' ideas circulated across all aspects of public culture in Mexico and beyond. As Stavans comments, Vasconcelos is often remembered less because of his educational crusade than as a result of his essentialist theory of the supremacy of the mestizo, ${ }^{418}$ which inspired student movements across Latin America and Chicanos in the US. ${ }^{419}$ Stavans notes that there is no proof that Chicano activists, such as Cesar Chavez and Dolores Huerta, had read La raza cósmica, rather, Vasconcelos' notion of hybridity "was simply in the air." 420 The book then became a sort of classic, "unread yet in the background." ${ }^{421}$ In Mexico, Vasconcelos helped consolidate mestizaje as the national ideology, which had a profound impact on the politics of race, education, culture and social engineering. For example, the art movement in the 1920 s redefined Mexico as brown and mestizo. In 1930, state statisticians dropped racial categories from the census, thereby endorsing the belief that Mexico was a homogeneous mestizo nation. Today, the legacy of mestizaje can be observed in varied forms of everyday life, such as the continuous denial of race and racism in public discourse, the fact that "mejorar la raza" is a popular saying and aspiration, the late-night infomercials selling skin-lightening products, the whiteness pervading prime-time telenovelas, all of which highlight that

\footnotetext{
418 Stavans, José Vasconcelos, 42.

${ }^{419}$ Ironically, Vasconcelos never acknowledged the place and role of Latinos/as in the US, even though he was clearly aware of the border (having been raised in Coahuila and educated in Texas). This elision of the Mexican diaspora was a common trend among Mexico City intellectuals. And when it was indeed represented, as in Octavio Paz's The Labyrinth of Solitude, it was full of negative stereotypes (see next chapter).

${ }^{420}$ Stavans, José Vasconcelos, 43.

${ }^{421}$ Ibid.
} 
mestizo is not so much a state of being but of becoming something more. As evident in the works of Vasconcelos and other intellectuals, this elusive "more" is entwined in the fabric of mestizaje since it connotes an ongoing struggle to achieve a greater degree of whiteness, culture and status. 


\section{Appendix A}

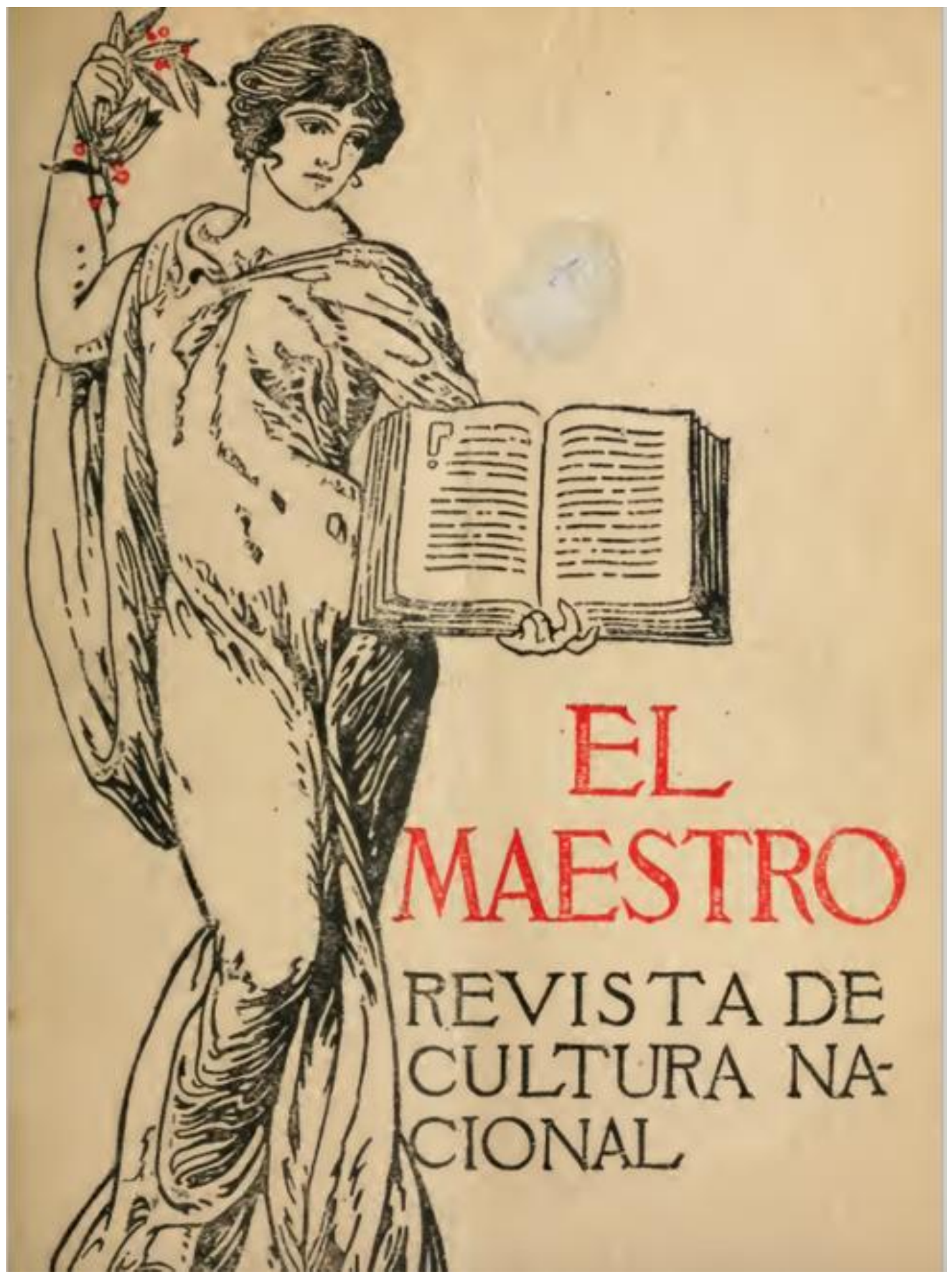

Retrieved from: https://archive.org/details/n1n3elmaestrorevista01mexi (accessed May 30, 2017). 


\section{Chapter Five}

\section{The Quest to Define the Mexican National Character}

From the 1930s to the 1950s, the study of mestizaje evolved into the study of mexicanidad, which sought to define what it means to be Mexican. Intellectuals of this period argued that an understanding of mexicanidad could help identify and correct the ills that were hindering the development of the nation. The interchangeable concepts of $l o$ mexicano and mexicanidad emerged from the revolutionary turmoil of the 1920 s as the central "organizing motif" for a society in search of a unifying sense of national belonging and identity. ${ }^{422}$ The construction of lo mexicano appropriated, celebrated and sanitized popular speech, images, symbols and idols in order to exhort all Mexican citizens to feel part of the new "Revolutionary Family," headed by the state, ${ }^{423}$ as well as to consolidate a unitary vision of nationalism that was to be inculcated in the cultural arena. $^{424}$

With the election of Manuel Avila Camacho in 1940 came a shift in revolutionary politics, from Lázaro Cárdenas’ socialism to a capitalist model of economic development, which favored large-scale properties over the ejido (communal land-holdings) and industry over agriculture. ${ }^{425}$ This period of industrialization and urbanization, intensified during the presidency of Miguel Alemán (1946-1952), brought about an economic "miracle" of growth that continued until the 1960s, as well as a heightened sense of

422 Gilbert M. Joseph et al., Fragments of a Golden Age: The Politics of Culture in Mexico since 1940 (Durham and London: Duke University Press, 2001 ), 7.

423 The state has been synonymous with the ruling party of the PRI, which was founded in 1929 as the National Revolutionary Party, renamed the Mexican Revolutionary Party in 1938 and the Institutional Revolutionary Party in 1946 (or PRI in its Spanish acronym). ${ }^{424}$ Ibid., 8.

${ }^{425}$ Doremus, "Indigenism, Mestizaje, and National Identity in Mexico During the 1940s and 1950s, 376" 
patriotism - reinforced after Mexico's entry into World War II in May 1942. The promotion of lo mexicano allowed the state to legitimize itself at the same time that it obscured the fact that its capitalist policies were responsible for increasing the socioeconomic divide and dependency on the United States, for dismantling agrarian progress, and for failing to address health care, housing and food shortages due to the massive urban population growth. ${ }^{426}$ The nationalist construct of mexicanidad was shaped, negotiated and contested by numerous actors and interests, and found expression across all aspects of culture, including art, literature, cinema, print journalism, consumer culture, tourism and television. ${ }^{427}$ However, historians Gilbert Joseph and Timothy Henderson note that intellectual musings on mexicanidad were seldom celebrations of Mexico's national spirit; these were more typically 'tortured reflections on the country's apparent inability to emerge from a prolonged and troubled adolescence." ${ }^{428}$ In other words, intellectuals were preoccupied with the fact that Mexico had failed to reach the level of development and progress of the US and Europe, and sought explanations in the disciplines of sociology, philosophy, history and psychology in particular. As discussed below, it became common for some intellectuals to locate the nation's social problems in a defective psyche.

Leading intellectuals Samuel Ramos and Octavio Paz were central actors in the psychological approach to lo mexicano. In this chapter, I explore how their respective celebrated works, El perfil del hombre y la cultura en México (Profile of Man and

${ }^{426}$ Michael N. Miller, Red, White and Green: The Maturing of Mexicanidad, 1940-1946 (El Paso, TX: Texas Western Press, 1999), 181.

427 Joseph et al., Fragments of a Golden Age, 9.

${ }^{428}$ Gilbert Joseph and Timothy Henderson, The Mexico Reader: History, Culture, Politics (Durham and London: Duke University Press, 2002), 9. 
Culture in Mexico, 1934) and El laberinto de la soledad (The Labyrinth of Solitude, 1950), helped shape and perpetuate many myths of lo mexicano that persist today. I focus in particular on Ramos' discussion of the racialized figure of the pelado (the urban proletariat) and Paz's arguments about the gendered icons of the Malinche, the Virgin of Guadalupe and the pachuco (a subculture of Mexican-Americans and Chicanos). I examine how both authors mobilize such icons to position women, the diaspora and others on the margins of what they deem to be the authentic Mexican nation.

Ramos was born to a middle-class family in the provincial state of Michoacán. He moved to the capital city to pursue a career in medicine at the Military Medical School only to abandon it for his philosophical endeavors. He taught philosophy at the National Preparatory School, edited the journal La antorcha (The Torch) and worked with philosopher José Vasconcelos, translating the so-called European classics for the latter's literacy program. ${ }^{429}$ Ramos also contributed to the Contemporáneos movement, whose founding members were concerned with creating a cosmopolitan literature that could counter the excessive cultural nationalism of the time, which they viewed as didactic and as stultifying creativity. Literary critic Guillermo Sheridan observes that the Contemporáneos were not only accused of being Europeanists, elitist, decadent and indifferent to the Mexican people but of being effeminate: "this analogy identifies revolutionary literature with virility and [other literature] with a biological 'transgression' that transfers onto the body a moral transgression. ${ }^{430}$ In other words, a virile and heterosexual masculinity became equated with national identity and political authority.

${ }^{429}$ Henry C. Schmidt, The Roots of Lo Mexicano: Self and Society in Mexican Thought, 1900-1934 (College Station, TX: Texas A\&M University Press, 1978), 41.

${ }^{430}$ Guillermo Sheridan, México en 1932: La polémica nacionalista (Mexico: Fondo de Cultura Económica, 1999), 35. 
National (-ist) literature was perceived to be masculine because it was accessible and dealt with "lo nuestro" (with Mexican themes). ${ }^{431}$

Following the Revolution, the Mexican elite began to attribute the nation's troubles to an insufficient manliness. The emergence of the figure of the homosexual as a political problem at this time served to establish the parameters that would define a macho and heterosexual national model. According to historians Anne Rubenstein and Víctor Macías-González, revolutionary ideology imagined the ideal Mexican citizen as overly masculine, working-class and darker-skinned in order to counter the Eurocentrism of the previous decades. ${ }^{432}$ Responding to the changing social and economic conditions of the 1940s, however, Ramos and Paz reconfigured Mexican masculinity and sexuality. In their writings, the brown, urban worker became the scapegoat of all the nation's ills, and the educated and middle-class man became the authentic Mexican citizen. While Ramos and Paz belonged to the Contemporáneos camp, arguing that founding an original Mexican culture was impossible because it was "European by definition," they nonetheless benefitted professionally from the strong Mexicanist current that took sway in this period. Ironically, while both authors were criticized for being too Europeanist, their aforementioned works were also hailed as the definitive studies of mexicanidad.

Paz was a renowned poet within the romantic tradition who received the Nobel Prize for literature in 1990. He was born in 1914 during the Mexican Revolution to an educated and politicized family; he spent his formative years like many other Mexican

431 Ibid., 37.

${ }^{432}$ Anne Rubenstein and Víctor Macías-González, Masculinity and Sexuality in Modern Mexico (Albuquerque, NM: University of New Mexico Press, 2012). 
intellectuals at the National Preparatory School in the capital city; and he served in the Mexican Foreign Service from 1944 to $1968 .{ }^{433}$ Political scientist Yvon Grenier comments that Paz was "the pivotal intellectual" of twentieth-century Mexico. ${ }^{434} \mathrm{He}$ enjoyed a certain degree of autonomy that allowed him to criticize the government at the same time that he benefitted from state patronage (ambassadorships, awards, grants, etc.). Like Ramos, Paz (re-) produced mexicanidad in his efforts to articulate the Mexican character within universal terms.

The goal of this chapter is to examine the vision of the nation and identity that Ramos and Paz propose, and the implications within the sociopolitical context. In the next section, I provide an analysis of El perfil del hombre y la cultura en México, focusing on how the image of the pelado materialized in the cinematic figure of Cantinflas in order to trace how ideas travel in the culture at large. ${ }^{435}$ In the second section, I look at El laberinto de la soledad and how the gendered myths of the Malinche and the Virgin are mobilized to reproduce patriarchy and the exclusion of women from the nation, as well as how these icons have been reclaimed by Mexican and Chicana feminists.

${ }^{433}$ David A. Brading, Octavio Paz and the Poetics of Mexican History, trans. Antonio Saborit (Mexico: Fondo de Cultura Económica, 2002).

${ }^{434}$ Yvon Grenier, "Octavio Paz: An Intellectual and His Critics," Mexican Studies/Estudios Mexicanos, 21 (2005): 253.

${ }^{435}$ When discussing the characters of Cantinflas and Tin Tan, I draw from the extensive literature on Mexican cinema and nation building (see Héctor Amaya, "Machismo in Cultural Criticism: Racializing Post-Revolutionary Mexican Masculinities," [paper presentation at the International Communication Association, San Francisco, CA, 2007]. Susan Dever, Celluloid Nationalism and Other Melodramas: From Post-Revolutionary Mexico to fin de siglo Mexamérica [Albany, NY: State University of New York, 2003]. Joanne Hershfield and David Maciel, Mexico's Cinema: A Century of Film and Filmmakers [Oxford, UK: SR Books, 1999]. Carl J. Mora, Mexican Cinema: Reflections of a Society, 1896-2004 [Jefferson, NC: MacFarland \& Company, Inc. Publishers, 2005]. Ramírez Berg, Cinema of Solitude). 


\section{El perfil del hombre y la cultura en México}

While neither Ramos nor Paz were trained in psychology and were more generally influenced by philosophy and literature, their works under discussion here were serious attempts to analyze the Mexican psyche. According to historian Graham Richards and other scholars, modern psychology proved attractive across different national contexts because it positioned itself as an ideologically "neutral" and scientific method that could readdress society's “intractable difficulties from a new angle - one which located the source of the problem safely at the individual psychological level." "436 The problem with psychology in this respect has been that in its aspiration to reach the status of a natural science in search of universal laws, it generalizes complex issues and homogenizes diverse populations. ${ }^{437}$ Moreover, psychologists have tended to fashion themselves as a kind of scientist, whose knowledge can help diagnose and prevent national degeneracy. ${ }^{438}$ Both Paz and Ramos, for example, view Mexican society as a sick patient in need of cure and themselves as the experts who can provide this cure. As I make evident below, psychology is a useful tool that allows the authors to ignore the sociohistorical causes of the phenomena they feared (e.g. mass poverty and underdevelopment) and to in turn pathologize lower-class men as deviant.

\footnotetext{
${ }^{436}$ Graham Richards, “'Race,' Racism and Psychology: Towards a Reflexive History (London and New York: Routledge, 1987), 67. Claude E. Buxton, Points of View in the Modern History of Psychology (London and New York: Academic Press, Inc., 1985). Ellen Herman, The Romance of American Psychology: Political Culture in the Age of Experts (Berkeley and Los Angeles: University of California Press, 1995). Glenda Sluga, The Nation, Psychology, and International Politics, 1870-1919 (New York: Palgrave Macmillan, 2006).

${ }^{437}$ Richards, “'Race,' Racism and Psychology, 297.

438 Sluga, The Nation, Psychology, and International Politics, 1870-1919.
} 
Ramos introduces his central thesis in the chapter entitled "The Psychology of the Mexican." In this chapter, he argues that Mexicans have "an exaggerated preoccupation to affirm their personality, are interested in everything that signifies power and have an excessive desire to predominate," and as such suffer from an inferiority complex. ${ }^{439}$ Drawing from the work of Austrian psychologist Alfred Adler ${ }^{440}$ Ramos posits that because Mexico came into "history when a mature civilization already prevailed," it felt insignificant in the way children do when facing adults: "The inferiority complex was born from this disadvantageous situation and was aggravated with the Conquest, mestizaje and even the disproportionate magnitude of nature." ${ }^{\text {441 }}$ Ramos here reproduces evolutionary thought, which highly influenced the emergence of modern psychology, and the "trope of infantilization," ${ }^{442}$ both of which frame non-European nations as being politically immature and in an earlier stage of human development in their life cycle. In this line of thinking, the development of nations becomes analogous to human maturation. Ramos then positions himself as the psychotherapist of the Mexican nation best suited to diagnose and treat its psyche. He warns that the portrait he will paint of the Mexican in the following pages "is not very flattering... but it is a relief to know that it can be changed. ${ }^{443}$ For Ramos, it is imperative to critique the Mexican character in order

\footnotetext{
${ }^{439}$ Ramos, El perfil del hombre y la cultura en México, 73.

${ }^{440}$ Adler was the founder of the school of individual psychology that took a holistic approach to the study of personality. At the basis of individual psychology was the notion of the inferiority complex, as Adler argued that "to be a human being means to feel oneself inferior" (Hertha Orgler, Alfred Adler: The Man and his Work [New York: Liveright Publishing Corporation, 1963]). It is telling then that Ramos views the inferiority complex as endemic to the Mexican character and more specifically to the urban poor.

${ }^{441}$ Ramos, El perfil del hombre y la cultura en México, 74.

${ }^{442}$ Shohat and Stam, Unthinking Eurocentrism, 137. ${ }^{443}$ Ramos, El perfil del hombre y la cultura en México, 71.
} 
to discover an "authentic" sense of self that can set the country on the right path of development. ${ }^{444}$

The second section of the chapter on psychoanalysis is entitled "El 'pelado." 445 Ramos explains that in order to understand the workings of "the Mexican mind," his focus will be on the Mexican pelado because he is the best expression of "the national character." ${ }^{446} \mathrm{He}$ clarifies that he is not interested in the pelado's "picturesque aspect, which has been endlessly reproduced in popular theater, novels and paintings." $\mathrm{He}$ continues: "[I am] only interested in his inner self to know which elemental forces determine his character. ${ }^{" 47}$ Ramos here critiques the cultural nationalism of the time that idealized the popular classes as authentic bearers of mexicanidad. His implication that these "picturesque" representations of the poor provide a false image of Mexico and that he, in turn, holds true insight reflects a power struggle over who had the authority to define "the 'genuine' Mexican character." ${ }^{\text {"48 }}$ The rhetorical strategy of labeling cultural nationalism as "inauthentic" enabled intellectuals like Ramos to discredit that movement and to enhance their role and importance in building a modern Mexican nation.

Ramos begins his non-picturesque description of the pelado as such: "The 'pelado' belongs to a most vile category of social fauna and represents the human waste of the big city. In the economic hierarchy, he is nothing but a proletariat, and in the

\footnotetext{
444 Ibid., 71-72.

${ }^{445}$ Literally, pelado means peeled or skinned, but as sociologist John Mraz observes, it can also be used as a reference to the shaved heads often seen on Mexico City's proletariat, "a form of lice control and hence a derisive appellation" (Looking for Mexico: Modern Visual Culture and National Identity [Durham and London: Duke University Press, 2009], 123).

446 Ramos, El perfil del hombre y la cultura en México, 76-77.

447 Ibid., 77.

448 Doremus, Culture, Politics, and National Identity in Mexican Literature and Film, 1929-1952, 84.
} 
intellectual one, he is a primitive...He has an explosive and dangerous nature...His explosions are verbal, with the intention of affirming himself in a crude and aggressive language. ${ }^{" 49}$ The powerful language Ramos uses in this excerpt underscores the horror and fear the educated middle-classes felt toward the growing urban proletariat. For example, the word "vile" (from the Latin vilis, meaning "of low value") not only indicates a thing or person of no value or worth, but someone who is both physically and morally repugnant. Moreover, a word such as "waste," which denotes a thing that is no longer useful, wanted or required, underlines the desire to eliminate the proletariat from the urban landscape. While Ramos claims at the beginning of the chapter that the Mexican is not to blame for his character, which is a product of history, here he pathologizes an entire group of people as deviant and in need of cure. Ramos further explains that in order to compensate for his total lack of socioeconomic power, the pelado takes refuge in machismo, which finds expression in a sexual wordplay. The pelado reassures himself of his worth, for example, by screaming to the world around him that at least he is a man with "muchos huevos" (big balls). ${ }^{450}$ Ramos borrows from Adler's notion of the "masculine protest" 451 to argue that the pelado's excessive display of masculinity and uninhibited aggression works as a mask to conceal his feelings of inferiority.

The negative characterization of the pelado as hostile, violent, resentful and animalistic is convenient because it could instill fear in the middle-classes (Ramos' core audience), who could then justify increased surveillance and containment of the

\footnotetext{
${ }^{449}$ Ramos, El perfil del hombre y la cultura en México, 77.

${ }^{450}$ Ibid., 80-81.

451 Adler defined the masculine protest as the tendency to compensate feelings of inferiority or inadequacy with an aggressive behavior (quoted in Orgler, Alfred Adler).
} 
proletariat. Moreover, the ahistorical use of the pelado as a metonym for the nation's troubles and defects serves to expiate those in power. Ramos places the blame on a disadvantaged group of men rather than taking the time to examine the sociopolitical context that had brought about uneven economic development, inadequate infrastructure and unemployment, and had made Mexican cities violent and uncomfortable places in which to live. ${ }^{452}$

It is important to point out that the depiction of the pelado is as much about class as it is about race. Media studies scholar Hector Amaya observes that Ramos' descriptions of "the lacking Mexican males were also arguments about the lacking Indians, the wanting dark mestizos, the deficiencies of AfroMexicans, and brutality of the poor. Mexico's shortcomings are, in view of these arguments, related to Mexico's racial shortcomings: Mexico is too dark for modernity." 453 In fact, Ramos states in the section entitled "The Mexican Bourgeoisie," in the same chapter on psychoanalysis, that this group is the "most intelligent and cultivated of all Mexicans," 454 as well as "the essence of the country, " 455 thereby underscoring his role and that of intellectuals as integral to the construction of a modern nation. Ramos further denigrates the brown urban worker by describing him as suffering from a "psychic imbalance," which accounts for his aggressive, violent and irascible behavior. ${ }^{456} \mathrm{He}$ then dismisses indigenous peoples and peasants as passive and silent, whose "social and spiritual influence is reduced today to

452 Rubenstein and Macías-González, Masculinity and Sexuality in Modern Mexico.

453 Amaya, "Machismo in Cultural Criticism," 19.

${ }^{454}$ Ramos, El perfil del hombre y la cultura en México, 91.

455 Ibid., 104.

${ }^{456}$ Ibid., 90. 
the mere fact of their presence." 457 Ramos' damning views on the urban poor and indigenous populations points to the widespread belief of the time that the heterogeneous masses, framed as an undifferentiated entity, were the obstacle blocking Mexico's path to development and progress - to be resolved through education and assimilationist practices.

The figure of the pelado made an appearance in cinema on a more positive light. The films of the Golden Age era (1930s-1950s) had the tradition of portraying the working classes (the main audience) as poor and honorable. Historian Anne Doremus and other scholars ${ }^{458}$ have noted that the idealization of the popular classes as morally and spiritually superior to the wealthy could enable filmmakers and the state, which subsidized the industry, to gain the audience's approval, diffuse class tensions, compensate them for the growing economic disparities, and "cultivate a sense of national identity, unity and pride. ${ }^{459}$ Moreover, historian Alex Saragoza argues that a popular genre such as the urban neighborhood film, whose ideological message was contentment in a life of poverty (the epitome of which is Nosotros los pobres [We the Poor], 1947), suggested that lo mexicano "resided among the poor" to the extent that any upward mobility "implied the acquisition of non-Mexican values, attitudes, manners, and dress. $"{ }^{460}$ It was thus the patriotic duty of the poor to remain in their place in order to keep lo mexicano alive.

\footnotetext{
${ }^{457}$ Ibid., 84-85.

${ }^{458}$ Dever, Celluloid Nationalism and Other Melodramas. Mora, Mexican Cinema. Ramírez Berg, Cinema of Solitude.

${ }^{459}$ Doremus, "Indigenism, Mestizaje, and National Identity in Mexico During the 1940s and 1950s," 400.

${ }^{460}$ Quoted in Ramírez Berg, Cinema of Solitude, 167.
} 
The pelado materialized in the beloved character of Cantinflas (see Appendix A), played by Mario Moreno, who emerged from the carpa, or popular theater. With baggy pants, ill-fitted felt hat, kerchief around his neck and uneven whiskers, Cantinflas represented the millions of mestizo and indigenous migrants who were entering the urban economy in the mid-twentieth century and were being asked to become modern citizens. Cantinflas provided lessons in adaptation and survival in the big city. He served as a point of identification and of belonging for audiences lost in the chaos of industrialization. Up to the 1950s, before his shift to the right, Cantinflas' humor derived from the ways in which he always outsmarted the rich and powerful, "confusing them with their own tools of domination" - with language. ${ }^{461}$ Cantinflas spoke fast and in a circular manner. He manipulated language to the point of unintelligibility, exasperating his bourgeois opponents. In the classic Ahí está el detalle (Here's the Point, 1940), his "ease with words," as he calls it, allows him to outwit the lawyers and judges who are wrongfully accusing him of theft and murder, as well as to mock bourgeois morals and customs, such as patriarchal family values and capitalism. For example, his nonchalant responses to his girlfriend's complaint that he is chronically unemployed include: "I have felt the need to work, but that is why I am a man, to suppress it like the machos" and "If work were any good, the rich would have cornered the market in it." Cantinflas' distinctive banter turned Moreno into the biggest Mexican star across the Spanishspeaking world. In 1992, the Royal Academy of the Spanish Language recognized his

${ }^{461}$ Mraz, Looking for Mexico, 123. 
status as a cultural institution by adding to its dictionary the verb cantinflear, meaning to talk a lot without saying much. ${ }^{462}$

The 1950s marked a shift in Moreno's comedy. At this time, Moreno began to play roles he had previously critiqued, such as priests, police officers and politicians, thereby taking his character of Cantinflas away from his marginal and working-class roots. Mraz comments that Moreno's subsequent films became preachy and tedious: "his formerly vital attitude toward the uses and abuses of language [was] replaced with word games that essentially den[ied] the existence of social problems." 463 Cantinflas' transformation into a more conservative figure reflects the notion of mimicry, which postcolonial theorist Homi Bhabha describes as "the desire for a reformed, recognizable Other, as a subject of difference that is almost the same, but not quite" (emphasis in original). ${ }^{464}$ In other words, Cantinflas became an acceptable cinematic figure because he represented a sanitized and domesticated version of the proletariat. He was a harmless and endearing prankster, better known in the diminutive as the peladito, who was content in his poverty, did not aspire to upward mobility and did not condemn social inequalities. Cantinflas thus represented an authorized and recognizable version of otherness.

Doremus observes that some of his films helped reinforce the Mexican status quo in two important ways. First, allowing the poor and the rich to laugh at each other worked to contain "social tensions that might have been resolved in otherwise disruptive ways."465

\footnotetext{
462 Jeffrey M. Pilcher, Cantinflas and the Chaos of Modernity (Wilmington, DE: Scholarly Resources, Inc., 2001), xviii.

${ }^{463}$ Mraz, Looking for Mexico, 127.

${ }^{464}$ Homi Bhabha, The Location of Culture (London and New York: Routledge, 1994), 86.

465 Doremus, Culture, Politics, and National Identity in Mexican Literature and Film, 1929-1952, 101.
} 
Second, portraying both classes as flawed but well-intentioned helped defuse class resentments. While Cantinflas' films emphasized the divide between rich and poor, they generally pointed "to a lack of communication as the only real problem between social classes." ${ }^{" 466}$ As Cantinflas concludes in his aforementioned film: "By speaking clearly, we can all understand each other." In the end, everyone gets along.

Ramos' theory on the inferiority complex of the Mexican is also mobilized to critique cultural nationalism. In the section entitled "Self-denigration," Ramos explains that because "we were born in the middle of an advanced civilization that was imposed on us, not by chance, but by our having a spiritual affiliation with it...we must admit that the only possible culture among us must be derivative" (emphasis in original) ${ }^{467}$ The efforts to create and celebrate an original Mexican culture are thus futile in his mind. Ramos notes that "the current nationalist reaction seems justified in its resentment against the Europeanist trend," which has blindly imitated Europe since the nineteenth century. ${ }^{468}$ He points out that European culture itself is not the problem, but rather the Mexican's need to imitate: "Imitation has been an unconscious phenomenon that reveals the peculiar nature of mestizo psychology. It is not vanity but the need to hide a lack of culture that determines imitation...imitation then works as a mechanism of defense that, in creating an appearance of culture, liberates us from the depressing feeling of inferiority." ${ }^{469}$ According to Ramos, the mestizo is prone to imitate because he has no cultural standards on which to fall back, and this causes him to feel inferior. The fact that the inferiority

\footnotetext{
466 Ibid.

${ }^{467}$ Ramos, El perfil del hombre y la cultura en México, 9-10.

${ }^{468}$ Ibid., 10-11.

469 Ibid., 12.
} 
complex alone is attributed as being responsible for Mexicans' suspicion and rejection of the foreign serves to obscure larger historical, cultural and social processes.

In a later section entitled "The Spanish Spirit in America," on the same chapter, Ramos explains that "our derivative culture" will be established not through imitation but through assimilation: "The difference between imitation and assimilation is the same as that of the mechanical and organic." 470 That he views assimilation as natural and inevitable effectively eradicates the violence and loss implicit in this practice. Moreover, Ramos here distances himself from his intellectual predecessors who viewed mestizaje as an essential process in the creation of a single, unifying nationalism. He observes, for example, "it is true there was a mestizaje, but not of cultures, because when the conquistadors came into contact with the indigenous, the latter's culture was destroyed."471 In Ramos' argument, indigenous peoples are nothing but an uncomfortable presence with no contributions to make to the modern Mexican nation. He further comments that the earliest elements that Mexico assimilated were language and religion, which functioned as the "civilizing agents" that "imprinted Catholic culture on the hearts of the new race" - a culture he designates as "criolla" (creole). ${ }^{472}$ Unlike other intellectuals, Ramos positions the white creole, rather than the mestizo, at the center of the Mexican nation. He continues: "the first influences that a young spirit receives are the most durable, [as such], the sediment of creole culture represents the most rigid aspect of the Mexican character." ${ }^{473}$ The argument that creole culture originated the Mexican

\footnotetext{
470 Ibid., 23.

${ }^{471}$ Ibid.

472 Ibid., 25-26.

${ }^{473}$ Ibid., 26.
} 
nation serves to render invisible indigenous peoples who are framed as waiting to be brought into history by the arrival of Catholic or Hispanic civilization.

Ramos does acknowledge that the mixture with indigenous populations after the Conquest led to the emergence of an "intermediate" race that was neither Spanish nor indigenous: "Man was no longer the same since the Indian had altered his white physiognomy with a touch of color" ${ }^{\prime 44}$ - here implying that indigenous influence is superficial, adding color to the Mexican race and not much else. He then notes that this state of in-between-ness is what caused the Mexican's "psychological conflict" from which "the peculiar accidents of our history have derived." 475 But it is clear that Ramos considers one side of the mestizaje equation more harmful for the Mexican psyche than the other. In the section entitled "El 'egipticismo' indígena," "476 Ramos proceeds to fix indigenous psychology and behavior as primitive in order to blame these peoples for the fact that modernity remains just beyond reach, as he does with the pelado. In one instance, he states that indigenous populations allowed themselves to be conquered "perhaps because their spirit was prone to passivity. Since before the conquest they were resistant to all changes...they were attached to their traditions; they were conservative and stuck in their ways. In their culture was imprinted the disposition for the immutable." ${ }^{477}$ Ramos clarifies that he does not believe that indigenous peoples are biologically inferior and that, in fact, they are able to "assimilate civilization," but only "when the individual is separated from the social group in which he was born," otherwise

\footnotetext{
474 Ibid., 31-32.

475 Ibid., 33.

476 The word "egipticismo" has no direct translation, but it refers to a state of immutability and a-temporality supposedly innate, in this case, to indigenous nature. ${ }^{477}$ Ibid., 36.
} 
the tendency to "resist, resent and disdain" change remains intact. ${ }^{478}$ Ramos concludes this damning section by lamenting that the indigenous proclivity for "egipticismo" seems to have spread among certain people (presumably the cultural nationalists) in Mexico who are "opposed to being swept away by the current of universal evolution." ${ }^{479}$ For Ramos, this resistance to change, or egipticismo, so entrenched in the Mexican psyche is the obstacle preventing Mexico's arrival to the banquet of civilization.

Ramos takes one final stab at cultural nationalism toward the end of the book, in the chapter entitled "Profile of Mexican Culture." In this chapter, he contends that the Mexicanist movement is equally responsible for producing a false image of Mexico as the blind imitation of European culture. He points to art and other media as having amplified this false image by focusing on the "picturesque" aspects of Mexico, which are suitable for international export and consumption, but say nothing about its reality. ${ }^{480} \mathrm{He}$ concludes his diagnosis of the Mexican psyche and culture by calling for "national introspection," for the need "to look into ourselves with depth and objectivity" in order to discover who Mexicans really are and how to begin creating a true national culture. ${ }^{481}$ It is not surprising that he views the middle-classes as the one with the "moral and intellectual discipline" to carry out such task. ${ }^{482}$

The fact that El perfil del hombre y la cultura en México condemns urban poor mestizos and indigenous peoples to a perpetual state of primitiveness enables Ramos to position himself and his fellow intellectuals as authentic Mexican citizens central to the
478 Ibid., 40.
479 Ibid., 38.
${ }^{480}$ Ibid., 146-147.
${ }^{481}$ Ibid., 148-149.
482 Ibid., 150. 
nation-building projects. Moreover, his focus on individual psychology allows him to mask the more serious socioeconomic problems of the time and to maintain intact the dominant power structures from which he benefitted.

\section{El laberinto de la soledad}

El laberinto de la soledad is an ambitious collection of eight essays, in which Paz discusses various topics that include colonialism, the Independence movement, the Revolution, the Mexican intelligentsia, and Mexican traditions, customs and religiosity. His central thesis is that Mexicans do not suffer from an inferiority complex (acknowledging Ramos' work) so much as from a profound sense of solitude, which

comes from the realization that "we are truly different. And we are truly alone." ${ }^{483} \mathrm{Paz}$ recommends that instead of retreating deeper into solitude, Mexicans should seek out their compatriots to establish universal communion. The main focus in this chapter, however, is not the notion of solitude but his analysis of the figures of the pachuco and the Malinche.

In his first essay, “The Pachuco and Other Extremes," Paz notes that his two-year residence in the United States inspired many of his reflections on mexicanidad. Unlike other intellectuals, Paz recognizes the existence of a Mexican diaspora, but portrays them in such a negative and patronizing light so as to deny them inclusion in the Mexican nation. Paz states that while he lived in Los Angeles, he was able to distinguish MexicanAmericans from the rest of the population because of a certain "furtive and restless air: they act like people who are wearing disguises, who are afraid of someone else's look ... [they resemble] a pendulum that has lost its reason and swings violently and erratically

${ }^{483} \mathrm{Paz}$, El laberinto de la soledad, 22. 
back and forth. This spiritual condition, or lack of spirit, has engendered the type known as "the pachuco." 484 The adjectives Paz employs to introduce the pachuco to his readers are telling, for they frame him at the outset as a dangerous figure. For example, the words "restless" and "erratic" denote constant but irregular movement. The word "furtive" (derived from the Latin furtum, meaning theft or thief) denotes a sly and secretive behavior. In short, Paz views the pachuco as an unpredictable being of whom society is right to be wary. He further explain that pachucos are a gang of Mexican-American youths, characterized by their flamboyant clothing, language and behavior, who suffer from an "almost fanatical" need to affirm their personality: "The purpose of their grotesque dandyism and anarchic behavior is not so much to point out the injustice and incapacity of a society that has failed to assimilate them as it is to demonstrate their personal will to remain different." 485 For Paz, the pachuco cannot be taken seriously because he is nothing more than an obstinate being who refuses to be incorporated into society.

Throughout the essay, Paz neglects to examine the historical causes that gave rise to this subculture, such as violence, poverty, racism, and processes of Americanization and assimilation, because he is more interested in the pachuco's individual psychology this "personal will" to be different - and only insofar as to what this has to say about the Mexican character. ${ }^{486}$ For example, Paz views the pachuco as seeking to provoke mainstream society, mainly through his extravagant style of dress, and to be persecuted in order to discover his true self: "the pachuco is an impassive and sinister clown whose

\footnotetext{
484 Ibid., 14.

485 Ibid., 15-16.

486 Javier Durán, "Border Crossings: Images of the Pachuco in Mexican Literature," Studies in 20 $0^{\text {th }}$ Century Literature, 25 (2001): 140-172.
} 
purpose is to cause terror instead of laughter...he knows that it is dangerous to stand out and that his behavior irritates society, but nevertheless he seeks and attracts persecution and scandal. It is the only way he can establish a more vital relationship with the society he is antagonizing." ${ }^{487}$ This evocative imagery of a clown terrorizing society serves to demonize an entire subculture and to dismiss the politics of pachucos, who mobilized their bodies to resist their own subordination. As historians Simon Webb and Luis Alvarez observe, the pachucos' loud and exaggerated style of fashion worked as a parody of bourgeois values, and was indeed confrontational in order "to make their lives more livable and meaningful" in the face of racial and socioeconomic disparities. ${ }^{488}$ Moreover, Paz's language ("impassive," "sinister," "terror"), which frames the pachuco as violent, threatening and unruly, serves to reinforce the belief widespread among the US and Mexican elite that the non-white urban proletariat had to be policed and contained for the benefit of the nation. The perpetuation of this stereotype also works to justify the systematic persecution, beatings and raids of Mexican-American youths (regardless if they were pachucos) that were well documented at the time in the US, but which the Mexican state paid little attention to and even refused to acknowledge. ${ }^{489}$ For Paz, the pachuco represents an "extreme" but inauthentic version of the Mexican character. Since

${ }^{487}$ Paz, El laberinto de la soledad, 17-19.

${ }^{488}$ Simon Webb, "Masculinities at the Margins: Representations of the Malandro and the Pachuco," in Imagination Beyond Nation: Latin American Popular Culture, ed. Terry Caesar and Eva P. Bueno (Pittsburgh, PA: University of Pittsburgh Press, 1998), 227264. Luis Alvarez, The Power of the Zoot: Youth Culture and Resistance During World War II (Berkeley and Los Angeles, 2008), 79.

${ }^{489}$ Durán, "Border Crossings," 146. 
he wants to be neither Mexican nor "Yankee," as evident by his hybrid aesthetics and language, the pachuco can only exist on the margins of both nations. ${ }^{490}$

The figure of the pachuco was popularized in Mexico by the comedian Germán Valdés and his character of Tin Tan (see Appendix B). Tin Tan did not enjoy the institutional acclaim and popularity of Cantinflas because his pachuco traits and demeanor represented an affront to the dominant and homogeneous notion of Mexican national identity. According to border studies scholar Javier Durán, the pachuco's "grotesque dandyism" that offends Paz works as a "statement of defiance, one that anticipates the creation of a counter identity at, and of 'the border,' a border identity." Pachuco culture is permeable and transnational; it is a "form of assemblage, a cultural affirmation of contradictions in the present rather than a nostalgic return to an imaginary original past. ${ }^{, 492}$ What most offended the Mexican cultural establishment about Tin Tan was his linguistic hybridity, that is, the fact that he mixed English and Spanish phrases (also known as pochismo). This hybridity was offensive enough that intellectuals and writers took the time to send letters to the Ministry of Public Education, asking to censor Tin Tan's movies because they "denigrated" the country. ${ }^{493}$

By the end of the 1940s, Valdés was becoming a star and Tin Tan was undergoing a process of "despachuquización" (unbecoming pachuco) that converted him into just another peladito seeking to enter modernity. ${ }^{494}$ For example, in one of his more popular

\footnotetext{
${ }^{490}$ Paz, El laberinto de la soledad, 19.

491 Javier Durán, 'Nation and Translation: The 'Pachuco' in Mexican Popular Culture: Germán Valdés' Tin Tan," The Journal of the Midwest Modern Language Association, 35 (2002): 42.

492 Ibid.

${ }^{493}$ Mraz, Looking for Mexico, 130.

494 Durán, "Nation and Translation," 44.
} 
films, El rey del barrio (King of the Neighborhood, 1949), Tin Tan leaves his house pretending to be a railway worker to impress his neighbors, but in reality spends his days killing time with a gang of pachucos at a bar; they drink, dance, sing and concoct elaborate plans to steal from the rich. Toward the end of the movie, after his son explains to him that he learned in school that a thief is "a despicable being and an enemy of society," Tin Tan has a change of heart. He returns some of the jewelry he had stolen and becomes an actual railway worker. In the end, he is a reformed citizen integrated into the capitalist economy. This despachuquización is significant because it highlights how Mexican nationalism has failed to incorporate border culture into its making. Durán observes that the Mexican establishment continues to view the pachuco, the Chicano and the northern border as tacky and grotesque, as a "Mexican-ness from over there" that is neither real nor authentic. ${ }^{495}$

The second figure of interest here is La Malinche, which Paz introduces in his fourth essay. It is worth pausing first on his comments on sexuality in the second essay entitled "Mexican Masks." Paz argues that Mexicans experience a sense of solitude because they are generally insular and suspicious of the world: "Popular language reflects to what extent we defend ourselves from the outside world: the ideal 'manhood' consists in the refusal to 'rajarse. ${ }^{496}$ Those who 'open up' are cowards...to open up is weak or treacherous. The Mexican...cannot allow the outside world to penetrate him." ${ }^{\text {"497 }}$ As such, women are inferior beings because it is in their nature to open up: "Their inferiority lies

\footnotetext{
495 Ibid., 46.

${ }^{496}$ Literally, the verb rajar means to tear, crack or split; it carries strong sexual connotations depending on its context.

${ }^{497}$ Paz, El laberinto de la soledad, 34.
} 
in their sex, in their 'rajada,' the injury that never heals." ${ }^{498}$ It is this "anatomical fatality"499 that fixes female sexuality as inherently unreliable and treacherous. Feminist scholar Cherríe Moraga notes that the potential accusation of "traitor" thus hangs heavy above the heads of most Mexican women and Chicanas seeking to develop an autonomous sense of self, particularly through sexuality. ${ }^{500}$

In his fourth essay, "Sons of Malinche," Paz introduces the similarly gendered verb of "chingar" (literally, to screw someone over). Paz explains that chingar is an active, masculine and aggressive verb that denotes violence: "[chingar] is to come out of ourselves and penetrate another with force. It also means to hurt, tear, violate - bodies, souls, objects - to destroy."501 The chingón is the macho, the one who opens up, and the chingada is above all the mother, the one who is passive, pure, inert and defenseless against being opened up. ${ }^{502}$ Paz points out that the fact that Mexicans were born from a woman makes all "sons of la Chingada, sons of Eve." ${ }^{503}$ And it is precisely this question of origins that has caused much "anxiety and distress" to the Mexican people. ${ }^{504} \mathrm{Paz}$ further contends that if the Chingada represents the violated mother, then "it is not presumptuous to associate it with the Conquest, which was also a violation... The symbol of this is doña Malinche, the lover of Cortés... [She] has become the figure that represents

\footnotetext{
498 Ibid.

499 Ibid., 45.

${ }^{500}$ Cherríe Moraga, Loving in the War Years: Lo que nunca pasó por sus labios (Brooklyn, NY: South End Press, 1983), 103.

${ }^{501}$ Paz, El laberinto de la soledad, 92.

502 Ibid., 91-93. Feminist philosopher Luce Irigaray notes that in a patriarchal system, only the term "male" has positive value, while the term "woman" or "female" is defined as the negation, the absence or privation of the central attributes of the male (quoted in Lisa Beljuli Brown, Body Parts on Planet Slum: Women and Telenovelas in Brazil [London and New York: Anthem Press, 2011], 63).

${ }^{503} \mathrm{Paz}$, El laberinto de la soledad, 96.

${ }^{504}$ Ibid., 97.
} 
the indigenous women who have been fascinated, violated or seduced by the Spanish. And just as the child does not forgive his mother for abandoning him to go search for his father, the Mexican people have not forgiven her betrayal." ${ }^{505}$ Malinche here becomes the metonym of the Mexican Eve, or great Chingada, who sold out her people to the Spanish and originated Mexico's fall from grace. As feminist scholar Tere Romo notes, Malinche has conveniently come "to signify that which is negative in regards to race (i.e. Indian), gender (i.e. female), and class (i.e. conquered people)." ${ }^{506}$ In other words, indigenous and female identity have become conflated into one and equated with treachery, danger, inferiority and servility, thereby serving to expiate those in power. La Malinche has also become code for a vendida, a whore and sellout to foreign values and interests. ${ }^{507}$

The conceptualization of Malinche as a lover who "gave herself willingly to the Conquistador"508 erases the sociohistorical environment in which she existed. Malinche's family offered her to the Spanish as part of a tribute that included chickens, maize and jewelry - she had no choice in becoming an object of exchange from one patriarchal society to another. However, she was not the passive woman Paz imagines her to be. Her knowledge of the Maya and Nahuatl languages turned her into Cortés' foremost interpreter and she acted as a mediator between native societies and the Spanish. Literary critic Sandra Messinger Cypess notes that the use of her voice challenged traditional

\footnotetext{
${ }^{505}$ Ibid., 103-104.

506 Tere Romo, "La Malinche as Metaphor," in Feminism, Nation and Myth: La Malinche, ed. Rolando Romero and Amanda N. Harris (Houston, TX: Arte Público Press, 2005), 140.

${ }^{507}$ Cultural critic Margo Glantz comments that the term malinchismo, which is used deprecatingly today to describe a preference for all things foreign or European, became popular in the 1940s among the cultural nationalists as a signifier of a lack of patriotism (La Malinche, sus padres y sus hijos [Mexico: Taurus, 2001], 280). ${ }^{508} \mathrm{Paz}$, El laberinto de la soledad, 104.
} 
gender roles and marked her as a dangerous disruption to both European and indigenous patriarchy. Her role as a communicator thus had to be downplayed in subsequent reformulations of the Conquest story. ${ }^{509}$ In Paz's work, for example, this role is ignored and Malinche is reduced to her biological functions, to being the violated womb that gave birth to the (illegitimate) Mexican people. Moreover, Chicano Studies scholar María Herrera-Sobek observes that the accusation of treachery does not seem legitimate because at this time indigenous peoples in Mesoamerica did not identify themselves as "Indians" united in a common cause against Europeans, rather, they saw themselves as Aztecs, Mayas, Mixtecas and so on. Since Malinche did not belong to any of these groups, how could she have betrayed any of them? ${ }^{510}$ Above all, Malinche was a survivor of her circumstances.

In Mexican nationalism, Malinche is condemned as the Chingada mother and is displaced by a more appropriate mother figure: the pure and chaste Virgin of Guadalupe. Ethnic studies scholar Norma Alarcón points out that Malinche functions as the "monstrous double" of Guadalupe. ${ }^{511}$ Malinche represents "feminine subversion and treacherous victimization of her people," while Guadalupe symbolizes "transformative powers and sublime transcendence. ${ }^{n 12}$ The latter also became the standard carried into battle in the revolutionary and independence movements. Paz, for example, describes

${ }^{509}$ Sandra Messinger Cypess, “'Mother' Malinche and Allegories of Gender, Ethnicity and National Identity in Mexico," in Feminism, Nation and Myth: La Malinche, ed. Rolando Romero and Amanda N. Harris (Houston, TX: Arte Público Press, 2005), 18. ${ }^{510}$ María Herrera-Sobek, "In Search of La Malinche: Pictorial Representations of a Mytho-Historical Figure," in Feminism, Nation and Myth: La Malinche, ed. Rolando Romero and Amanda N. Harris (Houston, TX: Arte Público Press, 2005), 130-131. ${ }^{511}$ Norma Alarcón, "Traddutora, Traditora: A Paradigmatic Figure of Chicana Feminism," Cultural Critique, 13 (1989): 58.

512 Ibid., 61. 
Guadalupe as "the consolation of the poor, the shield of the weak, the refuge of the oppressed. In sum, she is the Mother of orphans... she is the universal Mother." ${ }^{\prime 513}$ In contrast, Malinche embodies an "abject passivity: she does not resist violence, but is an inert heap of bones, blood and dust...this passivity, open to the outside world, causes her to lose her identity: she is the Chingada. She loses her name; she is no one; she disappears into nothingness; she is Nothingness. ${ }^{514}$ The negative essence that Paz attributes to the Mexican woman effectively erases her from history and from the symbolic family of the nation; it is the Mexican son that becomes a synecdoche for authentic Mexican-ness.

The mythic figures of Malinche and Guadalupe have worked to (re-) produce a series of expectations and moral codes about male-female behavior and relations in Mexico. While the virgin/whore dichotomy pressures all women under a patriarchal capitalist system, the image of Guadalupe places additional expectations on Mexican and Chicana women who are not only expected to be virginal but to be like the Virgin. Any woman seeking to assert her sexuality can potentially be accused of being a traitor or sell out. Author Sandra Cisneros poignantly captures the experience of growing up in a culture where Guadalupe is deployed as the main role model for women: "She was damn dangerous, an ideal so lofty and unrealistic it was laughable. Did boys have to aspire to be Jesus? I never saw any evidence of it. They were fornicating like rabbits while the Church ignored them and pointed us women toward our destiny - marriage and motherhood...As far as I could see, la Lupe was nothing but a goody two shoes meant to

${ }^{513} \mathrm{Paz}$, El laberinto de la soledad, 102-103.

${ }^{514}$ Ibid., 103. 
doom me to a life of unhappiness. Thanks but no thanks." 515 Cisneros' writings and the irreverent work of visual artists like Yolanda López are important contributions to the demythologization of an icon often mobilized to repress women's sexuality.

Chicana writers have similarly appropriated the image of Malinche in order to restore her voice and recover her contributions to history. As Messinger Cypess observes, Chicanas have reacted "to the negative presentations of Malinche as a direct defamation of themselves as women who bridge two cultures in their role as hyphenated peoples Mexican and American." 516 In other words, Chicanas view Malinche as a spiritual mother for her role in translating and navigating two opposing cultures. Cultural critic Alicia Gaspar de Alba likewise points out that Chicana feminists have revised Malinche's story "into a mirror of Chicana resistance against female slavery to patriarchy - be it the brown patriarchy of la Raza or the over-arching patriarchy of the white Father." has been reconfigured into a positive sign of “affirmation: of a woman's freedom to use her mind, her tongue, and her body in the way that she chooses and to cultivate her intellectual skills for her own survival and empowerment." 518 The appropriation of the Virgin and Malinche icons has allowed feminist scholars to challenge rigid cultural expectations and complicate the notion of Mexican female sexuality.

515 Quoted in Romero, "Foundational Motherhood: Malinche/Guadalupe in Contemporary Mexican and Chicana/Chicano Culture," in Feminism, Nation and Myth: La Malinche, ed. Rolando Romero and Amanda N. Harris (Houston, TX: Arte Público Press, 2005), 36.

${ }^{516}$ Sandra Messinger Cypess, La Malinche in Mexican Literature: From History to Myth (Austin, TX: University of Texas Press, 1991), 142.

517 Alicia de Gaspar de Alba, “Malinche's Revenge," in Feminism, Nation and Myth: La Malinche, ed. Rolando Romero and Amanda N. Harris (Houston, TX: Arte Público Press, 2005), 55.

${ }^{518}$ Ibid. 
Paz concludes El laberinto de la soledad on a similar note to that of Ramos, that is, with a critique of cultural nationalism. In the chapter entitled "The Mexican 'Intelligentsia,"' Paz begins by praising Vasconcelos, his role in education and his philosophy of The Cosmic Race, which recognized that "we are part of the Spanish universal tradition." ${ }^{519} \mathrm{Paz}$ then laments that the intellectual of his time has become institutionalized; he has become a state adviser and bureaucrat with no critical independence to create original work - no word here on how his own employment in the Mexican Foreign Service affected his autonomy, but the fact that he uses the third person plural pronoun to describe the intelligentsia enables him to distance himself from it. Paz notes that in order to maintain his material privileges, the intellectual has served and defended the state and has lost sight of his main role, which is to think and create work that "expresses lo nuestro," or that "searches for the national soul." ${ }^{520}$ He comments that Ramos' El perfil del hombre y la cultura en México continues to be "the only point of departure that we have to search for ourselves." 521 Paz then argues that mexicanidad functions like a mask: "it is a way of not being ourselves, a way of being and living something else." 522 Mexicanidad has ignored the fact that Mexican history is nothing but "a fragment of universal History" and as such, the intellectual must search for universal solutions to "problems that are not exclusively our own, but of all men." ${ }^{, 523}$ For Paz, the modern Mexican man is the "contemporary of all men."524

${ }^{519} \mathrm{Paz}$, El laberinto de la soledad, 185.

${ }^{520}$ Ibid., 199.

${ }^{521}$ Ibid., 193.

522 Ibid., 205.

${ }^{523}$ Ibid., 204, 207.

524 Ibid., 235. 
Paz makes it clear throughout El laberinto de la soledad that not all Mexicans can enter universal history, but rather, it is the male, educated, middle-class, fair-skinned Mexican who is fit to propel the Mexican nation into modernity. The mobilization of the binary myth of Malinche/Guadalupe, which repudiates the indigenous mother as a whore but exalts the virginal side of the mestiza woman, and the stereotypical image of pachuco/border culture serves to exclude indigenous peoples, women and the diaspora from Paz's imagined Mexican nation. These icons have also functioned to naturalize gender and racial hierarchies, which continue to influence male-female and ethnoracial interactions in contemporary Mexico.

\section{Conclusion}

While Paz and Ramos were critical of cultural nationalism, their careers proved productive in part because of it. El laberinto de la soledad and El perfil del hombre y la cultura en México became definitive studies of mexicanidad and their ideas were expanded in the fields of existentialist philosophy by the Hiperión group (led by Leopoldo Zea, Luis Villoro and others) and literature (Carlos Fuentes). Film studies scholar Charles Ramírez Berg notes that the search for lo mexicano has been criticized for being no more than "an elaborate game" played by intellectuals to entertain themselves, to obfuscate serious problems and to reinforce dominant structures of power. ${ }^{525}$ It is important to revisit and examine the popular works of Ramos and Paz to understand how certain ideas gain currency within the culture at large. For example, how is it that the image of Cantinflas was deemed acceptable to promote Mexico in the 1986 World Cup? Or that television had a Virgin-like protagonist as recent as 2005 in the

${ }^{525}$ Ramírez Berg, Cinema of Solitude, 5. 
Televisa telenovela La esposa virgen (The Virginal Wife)? Or that border/northern culture continues to be denigrated if not ignored altogether despite the fact that there are over 11 million immigrants in the US? It is imperative to begin demythologizing the nationalist figures that Ramos and Paz deployed in their works in order to allow for a more flexible understanding of Mexican identity (or rather, identities), which includes the experiences of those traditionally marginalized (the indigenous and urban poor populations) and those from "el otro lado" (the other side, the US). 
Appendix A

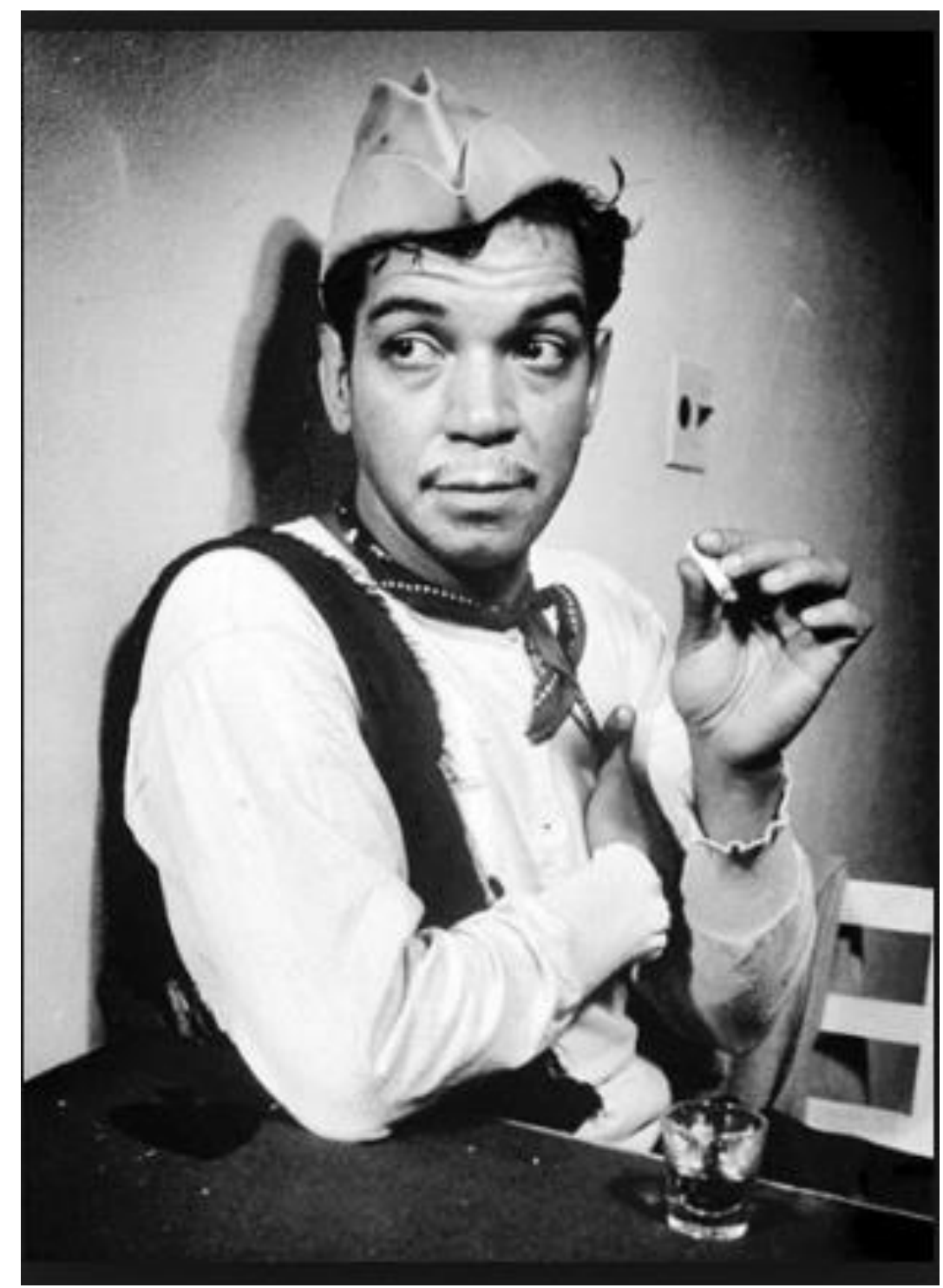

Retrieved from: https://www.pinterest.com/pin/337910778263264313/ (accessed May 30, 2017). 
Appendix B

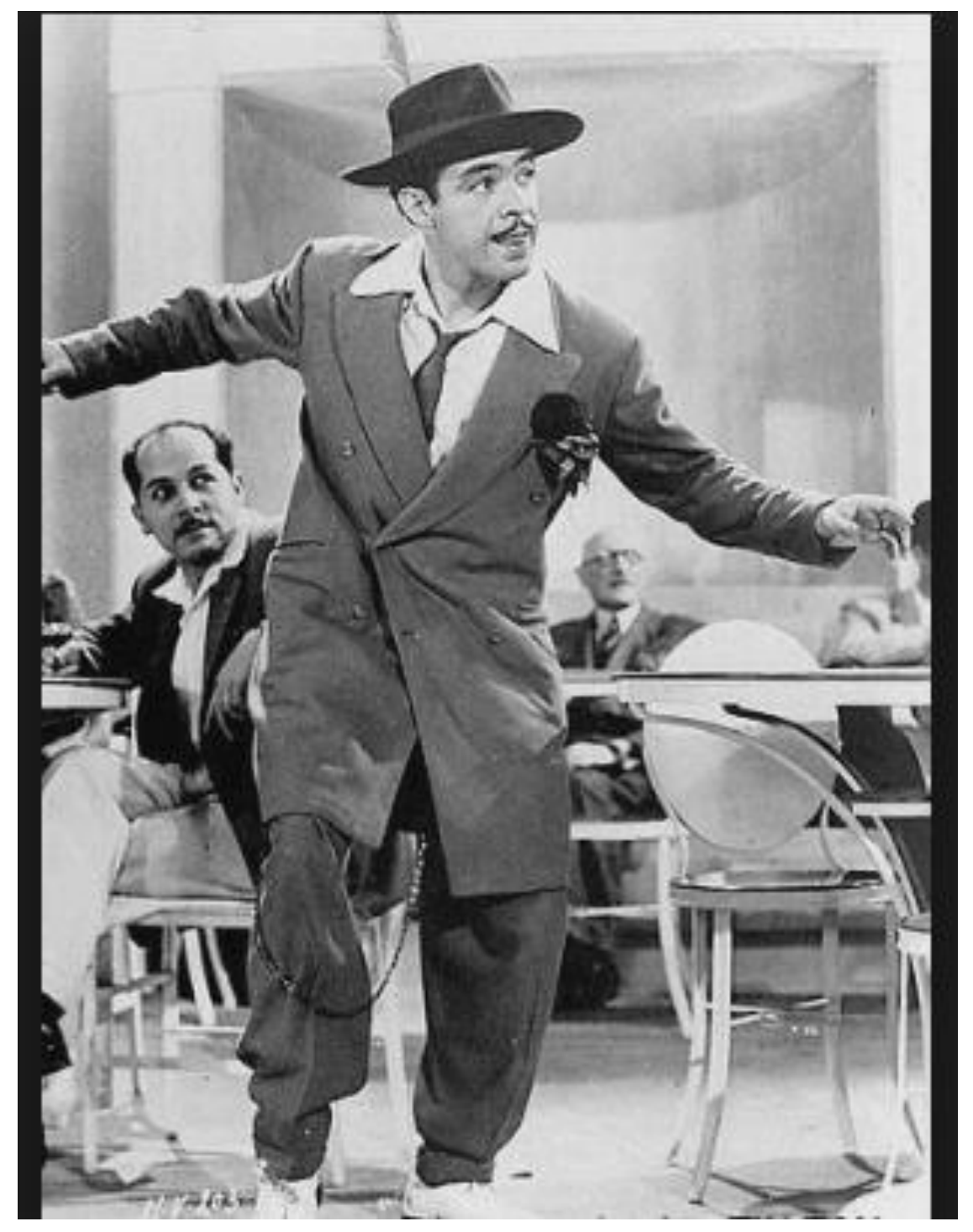

Retrieved from: http://www.sinembargo.mx/19-09-2015/1491129 (accessed May 30, 2017). 


\section{Chapter Six}

\section{Populist Politics: Indigenismo and Educational Telenovelas in Mexico}

From the time period of 1929 to the 1980s, the Institutional Revolutionary Party (PRI) in Mexico managed to maintain political legitimacy through a mixture of state corporatism, clientelism and the import substitution (ISI) model of development referred to as "classic populism." 526 The ISI policy is perceived as having supported political stability and economic growth at the same time that it increased state power. Historian Jolle Demmers comments that the ISI's positive role in the national economy allowed the PRI 'to both 'manipulate' - that is, undergird - its legitimacy by sending a flow of material benefits to its constituencies (in the form of subsidies and social programs) and 'repress' - that is, use its control in state companies, the media and the bureaucracy to co-opt or exclude - opposition." ${ }^{527}$ However, the student protests of 1968 and the exhaustion of the ISI model in the 1970s contributed to the breakdown of the PRI's hegemony and to the crisis of modern Mexico that erupted in the 80 s - described as the "lost decade."

Claire Brewster and other scholars remark that the year 1968 evokes the spirit of youthful rebellion and dissent "that dominated political and social spheres across the

\footnotetext{
526 Joelle Demmers, "Neoliberal Reforms and Populist Politics," in Miraculous Metamorphoses: The Neoliberalization of Latin American Populism, ed. Barbara Hogenboom et al. (London and New York: Zed Books, 2001), 150-181. Alan Knight, "Populism and Neo-Populism in Latin America, Especially Mexico," Journal of Latin American Studies, 30 (1998): 223-248. David Leaman, "Changing Faces of Populism in Latin America: Masks, Makeovers, and Enduring Features," Latin American Research Review, 39 (2004): 312-326. Jocelyn Olcott, "The Politics of Opportunity: Mexican Populism under Lázaro Cárdenas and Luis Echeverría," in Gender and Populism in Latin America: Passionate Politics, ed. Karen Kampwirth (University Park, PA: The Pennsylvania State University Press, 2010), 25-46. ${ }^{527}$ Demmers, "Neoliberal Reforms and Populist Politics," 152.
} 
world." ${ }^{" 528}$ More poignantly, film studies scholar Charles Ramírez Berg observes that Mexico's modern crisis dates back to the night of October 2, 1968, otherwise known as "la noche triste" (or the night of sorrow) ${ }^{529}$ The summer of 1968 in Mexico was characterized by a series of labor strikes and student protests against the corruption of the PRI and the perceived betrayal of the ideals of the Mexican Revolution. The PRI for its part feared that these demonstrations would tarnish Mexico's image abroad at a crucial time: the Olympic games were set to begin on October 12 in the capital city and were meant to showcase the nation's stability and progress. ${ }^{530}$

The student movement culminated on the night of October 2, when government troops surrounded and opened fire on a crowd of demonstrators who were gathered at the Plaza de las Tres Culturas (Three Cultures Plaza) to protest the occupation of the National Polytechnic Institute. The government justified the actions of the troops by claiming that student snipers had fired on the troops first. However, Mexican intellectuals, such as Carlos Fuentes, Carlos Monsiváis and Elena Poniatowska, and international reports on The Guardian and The New York Times noted the demonstration had been peaceful; they also countered the government's claim that 32 students had died, placing the number of fatalities as high as 300 to 500. Ramírez Berg points out that this

\footnotetext{
${ }^{528}$ Claire Brewster, "Mexico 1958: A Crisis of National Identity," in Cultural History and Literary Imagination, ed. Christian Emden and David Midgley (New York: Peter Lang Publishing, 2010), 149. Elaine Carey, Plaza of Sacrifices: Gender, Power, and Terror in 1968 Mexico (Albuquerque, NM: University of New Mexico Press, 2005). Demmers, "Neoliberal Reforms and Populist Politics."

${ }^{529}$ Ramírez Berg, Cinema of Solitude, 42.

${ }^{530}$ Brewster, "The Student Movement of 1968 and the Mexican Press: The Case of 'Excélsior' and 'Siempre!'” Bulletin of Latin American Research, 21 (2002): 171-190.
} 
sudden and violent governmental act of repression revealed that Mexico's revolutionary ideals and democratic aspirations were far from being achieved. ${ }^{531}$

The political situation in Mexico after 1968 looked more ominous as the former secretary of the interior, Luis Echeverría Alvarez, who is believed to have been the chief architect of the student massacre, was elected president in $1970 .{ }^{532}$ The Echeverría administration (1970-1976) initiated what is termed the apertura democrática (democratic opening), which included a series of concessions and reforms in the educational, political and economic sectors in an effort to restore its party's political legitimacy. ${ }^{533}$ The administration paid particular attention to indigenous education and development policies, which paved the ground for the resurgence of indigenismo and a host of debates about its role in Mexican society.

In this chapter, I explore the relation between indigenismo, anthropology and the state. While the main focus of this dissertation has been mestizaje, it is important to examine the development and institutionalization of indigenismo in order to have a deeper understanding of how Mexico has been imagined as a unified and homogeneous mestizo nation. Indigenismo can best be understood as a sweeping cultural, political and economic movement that extolled indigenous peoples and their cultures at the same time that it called for their modernization, assimilation and integration into national society. ${ }^{534}$

${ }^{531}$ Ramírez Berg, Cinema of Solitude, 42-43.

532 Ibid., 43.

${ }^{533}$ Alan Dillingham, "Indigenismo and its Discontents: Bilingual Teachers and the Democratic Opening in the Mixteca Alta of Oaxaca, Mexico, 1954-1982” (PhD diss., University of Maryland, 2012).

${ }^{534}$ Alexander S. Dawson, Indian and Nation in Revolutionary Mexico (Tucson, AZ: The University of Arizona Press, 2004). Laura Giraudo and Stephen E. Lewis, "PanAmerican Indigenismo (1940-1970): New Approaches to an Ongoing Debate," Latin American Perspectives, 39 (2012): 3-11. Stephen D. Morris, "Between Neo-Liberalism 
Indigenismo has worked as a twin strategy to mestizaje in the many projects of national consolidation in Mexico. Sociologist Emiko Saldívar observes that indigenismo has been a crucial part of the racial ideology of mestizaje, which has been mobilized to define indigenous peoples as "a group that needs to be integrated and developed by the mestizo nation-state. ${ }^{535}$ In other words, indigenismo has served to otherize indigenous peoples, framing them as objects of study, discipline and intervention that need to be incorporated into the nation. Indigenismo has thus worked to legitimize the state's politics and has "reproduced its right to govern." 536

The first two sections of this chapter provide an overview of the emergence of indigenismo in the 1920s and of the major critiques leveled against it by anthropologists in the 1970s. The decade of the 70s was crucial for Mexican anthropology as the younger generation of anthropologists, influenced by the Cuban revolution, decolonization movements across the world and Marxism, subjected the discipline to a critical revision and reformulation. The analysis of the pivotal text De eso que llaman antropología mexicana (Of that which They Call Mexican Anthropology, 1970) that I provide below highlights that for these critics, anthropology had betrayed its scientific and critical potential by serving the Mexican state as a tool of domination. Of particular concern was indigenismo, which they viewed as a paternalistic ideology and policy that perpetuated the misery and poverty of indigenous communities. De eso que llaman antropología

and Neo-Indigenismo: Reconstructing National Identity in Mexico," National Identities, 3 (2001): 239-255. Emiko Saldívar, "Everyday Practices of Indigenismo: An Ethnography of Anthropology and the State in Mexico," The Journal of Latin American and Caribbean Anthropology, 16 (2011): 67-89.

${ }^{535}$ Emiko Saldívar, Prácticas cotidianas del estado: Una etnografía del indigenismo (Mexico: Universidad Iberoamericana, 2008), 17.

${ }^{536}$ Ibid., 27. 
mexicana included the contributions of Arturo Warman, Margarita Nolasco Armas, Guillermo Bonfil Batalla, Mercedes Olivera de Vazquez and Enrique Valencia, all members of the National School of Anthropology and History (ENAH) in Mexico City.

In keeping with my interdisciplinary approach that critiques the distinction of value between texts, I also examine the role of television in this chapter. I explore how telenovelas helped support the state's development policies and the expansion of capitalism. While the Mexican television industry has been a private enterprise since its inception, the 1970s marked a time when the government contemplated the nationalization of television as a corrective to the industry's promotion of excessive consumerism and the dearth of educational programming. The government, however, opted to pressure Televisa with the task of creating educational and cultural programs. ${ }^{537}$ The most notable results in this decade include the adaptation of Sesame Street and the educational telenovelas produced by Miguel Sabido, which promoted literacy classes for adults, family planning methods, birth control and sex education for teenagers. The object of analysis in this section is the Mexican adaptation of the highly successful Peruvian telenovela Simplemente María (Simply Maria), first broadcast in 1969, which inspired Sabido's entertainment-education strategy that has been exported across the world.

\section{The Politics of Indigenismo}

Indigenismo and its Golden Age (1920s-1950s)

The Mexican Revolution of 1910 brought about a renewed commitment to addressing the problems faced by the country's large indigenous populations. Throughout the 1920s, a host of state agencies were founded with the intention to improve the well-

${ }^{537}$ Claudia Fernández and Andrew Paxman, El tigre: Emilio Azcárraga y su imperio Televisa (Mexico: Editorial Grijalbo, 2000). 
being of indigenous peoples. ${ }^{538}$ For example, agricultural cooperatives were created in 1920 to support indigenous communities. The Ministry of Public Education (SEP) for its part established the Cultural Missions, which sent a mix of rural and urban teachers to isolated villages "bearing a gospel of hygiene, athletics, and socialism." ${ }^{.539}$ In 1926, the Casa del Estudiante Indígena (Home of the Indigenous Student) was founded in Mexico City with the aim of demonstrating the potential of the indigenous student to become educated, modernized and integrated into the national society. In short, indigenismo by the mid-1920s had become integral to post-revolutionary Mexican nationalism. As historian Rick López observes, "to be truly Mexican, one was expected to...demonstrate a concern for the valorization and redemption of the Mexican Indian as part of the nation." 540

The administration of Lázaro Cárdenas (1934-1940) is generally considered to represent the apex of indigenismo. ${ }^{541}$ Cárdenas, for example, established the Department of Indigenous Affairs (DAI) in 1936 and the National Institute of Anthropology and History (INAH) in 1938. He is mostly remembered for his agrarian reform that set the precedent for the distribution of land in the form of ejidos (small parcels of communal land). Hispanic American Studies scholar Laura Giraudo notes that one of the most symbolic moments for indigenismo took place in April 1940 in the small town of Pátzcuaro in the state of Michoacán. From April $14^{\text {th }}$ to the $24^{\text {th }}$, Pátzcuaro welcomed approximately 250 guests from across the Americas to discuss the so-called "Indian

\footnotetext{
${ }^{538}$ Rebecca Earle, The Return of the Native: Indians and Myth-Making in Spanish America, 1810-1930 (Durham and London: Duke University Press, 2007).

539 Ibid., 188.

${ }^{540}$ Quoted in Earle, The Return of the Native, 189.

541 Dawson, Indian and Nation in Revolutionary Mexico. Earle, The Return of the Native. Giraudo and Lewis, "Pan-American Indigenismo (1940-1970)."
} 
question" at the First Inter-American Indigenous Congress, convened by the DAI. ${ }^{542}$ Giraudo points out that indigenismo took on a specific meaning in Pátzcuaro as "a special policy or 'a set of desiderata, standards, and measures' targeting a population group with particular needs." ${ }^{543}$ Furthermore, historian Alexander Dawson comments that Pátzcuaro was significant for indigenismo because it represented a crucial moment in the convergence of the social sciences and state formation in Mexico. ${ }^{544}$

The conference featured an array of intellectuals who advocated a limited notion of cultural pluralism as indispensable to the policies of integration - limited in the sense that indigenistas retained the authority to determine which indigenous traits were positive and worth preserving for the nation and which were not. One of the leading proponents of this version of pluralism was the educator Moisés Sáenz, who had previously argued that heterogeneity had to be reduced "in the interest of ameliorating poverty." "545 This paternalistic attitude that characterized many intellectuals of the time is also evident in Sáenz's definition of the term "indigenista," which he coined to identify the "promoters of a policy related to the Indian, or the implementers of programs that seek their 'redemption' with an essential degree of 'emotion.",546 The idea of redemption is convenient because it frames indigenous peoples as being defective and thus in need of the assistance of the mestizo intellectual in order to become acceptable and full Mexican citizens.

542 Giraudo, 'Neither 'Scientific' nor 'Colonialist': The Ambiguous Course of InterAmerican Indigenismo in the 1940s," trans. Victoria J. Furio, Latin American Perspectives, 39 (2012): 12-13.

543 Ibid., 13.

${ }^{544}$ Dawson, Indian and Nation in Revolutionary Mexico, 83.

545 Ibid., 71.

${ }^{546}$ Quoted in Giraudo, "Neither 'Scientific' nor 'Colonialist,"” 14. 
In 1940, Sáenz was appointed provisional director of the Inter-American Indigenous Institute (III), an intergovernmental agency designed to address the "Indian question" and approved at the Pátzcuaro conference. After his untimely death in October 1941, Sáenz was replaced by the established anthropologist Manuel Gamio (thus further reinforcing the mutual interdependence between anthropology and the Mexican state). As director of the III from 1942 to 1960, Gamio promoted an indigenismo that claimed to have a "scientific orientation" and was rooted in applied anthropology. ${ }^{547}$ This type of indigenismo emphasized cultural over structural and socioeconomic factors as the main obstacle to the integration of indigenous peoples. Giraudo comments that "by adopting applied anthropology as a legitimating principle," indigenistas could present themselves as scientific, professional and apolitical, which in turn allowed them to exert greater influence as experts in the state apparatus. ${ }^{548}$

With the presidential elections of Manuel Avila Camacho in 1940 and Miguel Alemán in 1946, both of whom emphasized a capitalist model of development for the country, the "Indian question" began to lose importance. In fact, Alemán dissolved the DAI in 1946, relegating all matters pertaining to the study and education of indigenous peoples to the SEP. Alemán's decision to close the DAI attracted a flurry of angry protests from intellectuals, indigenistas and indigenous peoples, who feared that the federal government had abandoned its commitment to improve the welfare of their communities. ${ }^{549}$ In order to appease his critics, Alemán founded the National Indigenous Institute (INI) under the leadership of the anthropologist Alfonso Caso in 1948.

${ }^{547}$ Ibid., 17.

548 Ibid.

${ }^{549}$ Dawson, Indian and Nation in Revolutionary Mexico, 142. 
In the 1950s, the INI launched a series of initiatives in highland Chiapas and other impoverished states to promote schools, bilingual education, health care, infrastructure, economic development and the popular arts. Historian Stephen Lewis notes that the INI's early work was highly innovative and at the vanguard of indigenista theory and practice across the Americas, but limited financial resources and responsibilities crippled its success. Low budgets brought to a halt programs in agriculture, animal husbandry and forestry, and severely compromised programs in education and health care. ${ }^{550}$ In fact, the inability to meet demand for education forced the INI to forge a closer relationship with the SEP, which ultimately undermined bilingual education. ${ }^{551}$ For the SEP, learning to speak and write Spanish meant progress and modernization. In addition to dealing with anemic budgets, indigenistas had to work long hours for a low salary in a hostile environment, where local non-indigenous families viewed them as "meddlesome outsiders. ${ }^{" 552}$ All of these factors contributed to the malaise that set in among indigenistas, some of whom resigned from the INI. By the mid-1960s, the INI had ceded its educational program to the SEP and its health care program to the Ministry of Health, and was no longer in charge of major development programs. ${ }^{553}$ The gradual dissolution of the INI's endeavors mirrored the government's loss of interest in indigenismo.

\section{Indigenismo and its Discontents (1960s-1970s)}

In April 1968, the town of Pátzcuaro again welcomed hundreds of delegates from the Americas to celebrate the sixth Inter-American Indigenous Congress. The congress

${ }^{550}$ Lewis, "Indigenista Dreams Meet Sober Realities: The Slow Demise of Federal Indian Policy in Chiapas, Mexico, 1951-1970," Latin American Perspectives, 39 (2012): 64.

${ }^{551}$ Ibid., 76.

${ }^{552}$ Ibid., 73.

${ }^{553}$ Ibid., 74. 
was marked by growing internal divisions among participants, many of whom were influenced by the early success of the Cuban revolution, decolonization movements in Africa and Asia, Marxism, socialism and dependency theory. ${ }^{554}$ Historian Alan Dillingham points out that one of the many self-reflexive discussions that took place at the congress concerned terminology itself. For example, while indigenistas had previously avoided categories of race in their efforts to distance themselves from scientific racism, the 1968 congress reintroduced the language of race and racial discrimination. In fact, the veteran Mexican anthropologist Caso argued in his opening statement that it was imperative to combat discrimination against indigenous peoples. ${ }^{555}$ Moreover, the notion of delegados indígenas (indigenous delegates) used to describe indigenous participants at the congress became a source of conflict. For some intellectuals, this term underscored the paternalism embedded in indigenismo, which often treated indigenous peoples as objects of study and redemption rather than as active participants. The term "delegados" was then changed to dirigente indigena (indigenous leader) in 1964 and to líderes de las organizaciones indígenas (leaders of indigenous organizations) in $1972 . .^{556}$

Other points of contention at the conference included the complicity of indigenismo and development policies in the exploitation of indigenous peoples as untapped economic resources. As Saldívar notes, the concept of development is not innocent of power. Development policies seek to "explain inequality as a problem of

${ }^{554}$ Roberto J. González, "From Indigenismo to Zapatismo: Theory and Practice in Mexican Anthropology," Human Organization, 63 (2004): 141-150.

${ }^{555}$ Dillingham, "Indigenismo and its Discontents," 86.

556 Ibid, 91. 
progress and backwardness" - in relation to the capitalist system. ${ }^{557}$ These policies posit that the "less developed" (the poor, the indigenous, etc.) need to be pushed into development, thereby "legitimizing the expansion of capitalism." ${ }^{558}$ Critics at the conference argued that indigenismo was at its homogenizing worst when advancing development projects that sought to transform indigenous populations into productive citizens at all costs. Many of these critics were influenced by the theories of dependency that had emerged in the 1960s as a challenge to North American imperialist expansion and the capitalist system. ${ }^{559}$ Much like Marxism before, these theories imagined the urban poor, peasants and indigenous peoples as sharing a single and unified class struggle, which could be resolved through economic solutions. However, dependency theories failed to take into consideration how ethnic, cultural and racial identities play a part in people's subordination and marginalization. The more radical strand of dependency theorists at the conference also introduced the notion of internal colonialism, which caused furor among the older generation of indigenistas who felt were being indicted as having supported colonial structures and relations in Mexican society. ${ }^{560}$

The sixth Inter-American Indigenous Congress anticipated the range of opinions, voices and debates concerning the politics of indigenismo that thrived in the 1970s. While some would continue to express loyalty to official indigenismo, others called for its reformulation. A new generation of anthropologists and social scientists was especially critical of official indigenismo, describing it as an ineffective, paternalistic and assimilationist project designed to maintain the status quo. Two of the most forceful

${ }^{557}$ Saldívar, Prácticas cotidianas del estado, 27.

558 Ibid.

${ }^{559}$ Larrain, Identity and Modernity in Latin America, 123.

${ }^{560}$ Dillingham, "Indigenismo and its Discontents," 98. 
critiques of indigenismo appeared in De eso que llaman antropología mexicana (discussed shortly) in 1970 and the Barbados Declaration in 1971. The latter publication was the result of a symposium held in Barbados, where Latin American anthropologists deliberated on the colonialist nature of indigenista policies and accused national states of having participated, directly or indirectly, in the genocide of indigenous communities. The declaration also criticized anthropology as an "instrument of colonial domination," which has "offered knowledge and procedures that have served to maintain, reinforce or mask colonial relations. ${ }^{5561}$ The declaration concluded by stating that Latin America requires an anthropology that understands indigenous peoples to be subjects of colonization and not mere objects of study, and it is thus "committed to the struggle for their liberation." ${ }^{562}$

During the 1970s, indigenous communities and their political activities gained more visibility and international support. Official indigenismo evolved into a "participative" type of policy that encouraged indigenous peoples to take leading roles in the creation of community development programs. ${ }^{563}$ This transformation was possible due to President Echeverría's renewed interest in indigenista practice and the incorporation of critical anthropologists into state agencies. Between 1970 and 1976, his administration increased the INI's budget fivefold and established 58 new Indigenista Coordinator Centers throughout the country. Echeverría also helped organize the Indigenous Congress in Pátzcuaro in 1975, where the National Council of Indigenous Peoples (CNPI) was established to serve as a mediator between indigenous communities

${ }^{561}$ Quoted in Carlos García Mora and Andrés Medina, La quiebra de la antropología social en México (Mexico: Universidad Nacional Autónoma de México, 1986), 524. 562 Ibid.

563 Giraudo and Lewis, "Pan-American indigenismo (1940-1970)." 
and the state. ${ }^{564}$ The INI's director, anthropologist Gonzalo Aguirre Beltrán, was replaced by Ignacio Ovalle, who argued that he intended "to put an end to the compulsory measures aiming at homogenization, as well as to paternalistic measures which might displace the [indigenous] communities' own initiative or prevent the development of creative potential in theses groups." ${ }^{565}$ In this statement, Ovalle declared his intention to rid the INI of its homogenizing tendencies and announced his commitment to act as an ally in the indigenous struggle for liberation.

Under the administration of José López Portillo (1976-1982), several new programs and departments were founded at the federal and state levels to support indigenous communities and their cultures. These initiatives included the Program for the Training of Bilingual Technicians in Indigenous Culture, the Program for the Defense and Development of Native Cultures, which promoted traditional art and techniques, the Anthropological and Social Organization Research Department, the Publishing Department, the Audiovisual Archive and the Broadcasting Department, which established a national network of radio stations to broadcast in indigenous languages. According to Latin American studies scholar Rosalva Aída Hernández Castillo, the main weakness of this so-called "participative" model of development was that indigenista policies were mostly developed in the capital city by urban mestizo intellectuals and civil servants who were out of touch from indigenous reality. ${ }^{566}$ The chasm between rhetoric and practice was evident in the lack of indigenous personnel in state institutions. For example, none of the Indigenista Coordinator Centers were under indigenous

\footnotetext{
${ }^{564}$ Rosalva Aída Hernández Castillo, Histories and Stories from Chiapas: Border Identities in Southern Mexico (Austin, TX: University of Texas Press, 2001), 105. 565 Ibid., 112.

566 Ibid., 113.
} 
management and most of the INI indigenous employees were relegated to the menial jobs of janitors or drivers, and at best, to research assistants or translators for local anthropologists. ${ }^{567}$ As Saldívar points out, the politics of the INI were oftentimes more useful in legitimizing the institution's existence in indigenous communities and in the federal state than in promoting the welfare of these communities. ${ }^{568}$ Despite its good intentions, participative indigenismo reproduced the paternalism embedded in official indigenismo since it continued to treat indigenous peoples as uneducated and ill prepared to devise their own means of liberation.

De eso que llaman antropología mexicana (1970)

This sardonically titled book, published by the independent press Editorial Nuestro Tiempo in Mexico City, is a short collection of five essays written by five different anthropologists. All of the authors had graduated from the ENAH and were teaching courses at the National Autonomous University (UNAM) and the IberoAmerican University in Mexico City at the time of writing. The first essay, written by Arturo Warman and entitled "All Saints and All Dead: Historical Critique of Mexican Anthropology," provides a biting critique of anthropology as it developed in Mexico from the time of the Conquest to the present and sets the tone for the rest of the anthology. Warman begins by stating that the discipline of anthropology is a product of Western civilization that consolidated itself at a time of European imperialist expansion. He notes, "the anthropological tradition is thus a 'scientific' auxiliary to white expansion; it has contributed to it by offering information about other cultures and by trying to make

567 Ibid.

${ }^{568}$ Saldívar, Prácticas cotidianas del estado, 60. 
the unequal power relations more acceptable, less troublesome and more profitable." ${ }^{569}$ In other words, Warman views anthropology and its accumulation of knowledge about other peoples and cultures as a crucial tool that facilitated European colonialism.

In the next 25 pages, Warman proceeds to outline the development of the anthropological tradition in Mexico. He comments that the "Indian question" emerged as early as the $16^{\text {th }}$ century, when various social groups that included the Spanish crown and the Church debated what to make of the large indigenous populations. He summarizes the range of opinions that predominated at the time on a section entitled "Ideologies" as such, "there were those who doubted the humanity and rationality of the Indian. There were those who claimed he was inferior...The majority of anthropological thinkers articulated the Indian's potential to become equal as well as his real inferiority. The Indian could become equal as long as he stopped being an Indian and whitened himself culturally; in the meantime, he had to be protected. Protectionism became the official policy of the crown and the Indian was given the legal treatment reserved for children. Equality, henceforth, became the monopoly of whites. $" 570$ In other words, the white elite retained the right to distinguish full citizens from part citizens, or strong citizens from weak ones. While Warman observes that these ideologies that frame indigenous peoples as children in need of protection have proved to be remarkably resilient throughout time, having taken root in the theories and policies of indigenismo, he does not intend to suggest that anthropology is a monolithic discipline. He points to the work of Dominican friar

\footnotetext{
${ }^{569}$ Warman et al. De eso que llaman antropología mexicana (Mexico: Editorial Nuestro Tiempo, 1970), 11.

${ }^{570}$ Ibid., 14.
} 
Bartolomé de las Casas as evidence that Mexican anthropology has always made room for dissident thought.

Throughout the essay, Warman traces the evolution of the term "Indian." For example, he notes that from being considered irrational and subhuman during the colonial regime, the "Indian" was granted legal equality after Independence. In his characteristic wry speech, Warman describes the Independence period on a section entitled "We are Equal" as such, "One of the first declarations of this new country was that of equality for all. Beautiful gesture! Equal, but not at the same level. In order to enjoy the privilege of equality, it was necessary to speak, write and read the language of the West, to dress like Europeans and to preferably be of a lighter color." ${ }^{571}$ Warman here contends that while the "Indian" was elevated at the rhetorical level, he continued to occupy the most marginalized sector of society during the Independence era, which reproduced many of the white supremacist ideologies of the colonizers. Warman then comments that the Liberal period of the 1850s brought about a new batch of intellectuals, influenced by the romantic movement, who viewed the "Indian" as an "exotic survival of the glorious past;" their interest in preserving the remnants of pre-Columbian civilizations gave rise to the first ethnographic studies in Mexico. ${ }^{572}$ According to Warman, Mexican ethnography was formed through the adoption of European and North American anthropological theories and methodology. As such, the contemporary "Indian" in Mexico was understood to be "an anomaly standing on the margins of Western history and progress, conceived as the natural destiny of humanity. ${ }^{, 573}$ In addition to deriding the presumption

${ }^{571}$ Ibid., 17.

572 Ibid., 18.

${ }^{573}$ Ibid., 22. 
of Western anthropology to be a universal discipline, Warman critiques the exoticization of indigenous peoples, which has served to naturalize their supposed cultural backwardness and has justified their exploitation.

The persistent belief that the "Indian" was a problem that needed to be resolved gained more strength during the administration of Porfirio Díaz (1876-1911). The "Indian" was conceived to be poor and ignorant, and the main obstacle blocking the path to modernity and progress. Warman here is especially critical of the set of solutions that were proposed to resolve the "Indian problem," including mestizaje and European immigration, which to him are code for the ultimate extermination of indigenous peoples. ${ }^{574}$ Warman notes that it was the Revolution that brought about the recognition of the need to transform the country's socioeconomic structures in order to improve the welfare of indigenous populations.

With the violence and chaos of the Revolution came the urgency to create a unified nation. Warman notes that "all intellectuals became politicians" at this time, as anthropologists, archeologists, ethnologists, folklorists and artists willingly participated in the varied projects of national unification. ${ }^{575} \mathrm{~A}$ prime example of this was the aforementioned anthropologist Gamio, who argued that the formation of a homogenous Mexican nation was possible through the integration and assimilation of indigenous peoples into national society (see third chapter). For Gamio, the actions of the anthropologist were the actions of the state itself, and as such, science and state should operate as one entity. Warman laments, "Since then, anthropology became voluntarily tied to the service of power, establishing the basis that would turn this marital union into

${ }^{574}$ Ibid., 24.

${ }^{575}$ Ibid., 26, 29. 
concubinage. And now we are paying for it." ${ }^{" 576}$ The metaphor of a concubine type of relationship between anthropology and the Mexican state proves illuminating because it shows that for Warman and his generation, anthropology and its intellectual endeavors had become subordinated to the politics of the state.

In the remainder ten pages of the essay, Warman provides a forceful critique of official indigenismo and its institutions. For example, he describes indigenismo as "the vehicle for industrialist expansion" and anthropologists as "the theoretical drivers." ${ }^{, 577} \mathrm{He}$ criticizes his own alma mater, the ENAH, for having perpetuated the bureaucratization of anthropology and its integration into the state machinery. ${ }^{578}$ Warman also dismisses the First Inter-American Indigenous Congress for its efforts to nationalize (or de-Indianize) indigenous peoples. In short, he contends that anthropology betrayed its scientific vocation as it became institutionalized. Warman concludes by condemning Mexican anthropology as an instrument of the colonizer that lacks theoretical foundations, originality and independence ${ }^{579} \mathrm{He}$ does not propose concrete solutions on how anthropology might be improved and instead ends on a more somber tone, noting that the scarcity of critical anthropologists can also be attributed to the repressive and authoritarian nature of the Mexican government. ${ }^{580}$

In the second essay entitled "From Revolutionary Indigenismo to Critical Anthropology," Guillermo Bonfil Batalla offers a sharp critique of indigenismo. He observes that the central tenets of official indigenismo have been upheld in the present:

\footnotetext{
${ }^{576}$ Ibid., 29.

${ }^{577}$ Ibid., 31.

${ }^{578}$ Ibid., 33.

${ }^{579}$ Ibid., 36-37.

${ }^{580}$ Ibid., 37.
} 
"All the goals of revolutionary indigenismo remain unscathed, disconnected from reality, firmly rooted in its contradictory ethnocentrism that valorizes an imaginary society...The Indian must be 'educated' so that he abandons his 'bad habits,' so that he changes his attitude and mindset, so that he produces more and consumes more, so that he is on equal footing with other Mexicans...And this and only this defines indigenismo. ${ }^{" 581} \mathrm{He}$ continues on the next page, "If something defines indigenista politics is its attempt to eradicate the ethnic personality of the Indian." 582 Bonfil Batalla here contends that indigenismo is essentially an ethnocentric endeavor that has exploited and manipulated indigenous peoples and cultures for the benefit of Mexican national society. For example, he later observes that Mexican nationalism has appropriated indigenous traditions and customs to add an element of uniqueness and folklore to the national culture - a strategy that has proved successful in attracting international tourism and investment - at the same time that it negates the presence of contemporary indigenous peoples. ${ }^{583}$ Moreover, Bonfil Batalla remarks that the integrationist projects endemic to indigenismo have been misguided because they have directed their efforts toward "the transformation and redemption of the Indian," rather than to disrupting the power structures that perpetuate the colonial relations of exploitation that characterize the lives of indigenous populations. ${ }^{584}$ For him, cultural pluralism is not the issue preventing the consolidation of a single nationality, but rather the "exploitation and subjugation" of those who are deemed different. ${ }^{585}$ Although he briefly mentions the need to recognize Mexico as a

\footnotetext{
581 Ibid., 43.

582 Ibid., 44.

583 Ibid., 53.

${ }^{584}$ Ibid., 45, 55.

585 Ibid., 59.
} 
multicultural country in two separate pages, this idea was to become the central thesis of his monograph México Profundo (Deep Mexico, 1996), discussed in the next chapter.

Bonfil Batalla shares with Warman the viewpoint that Mexican anthropology has functioned as an instrument of domination. He notes that the anthropologist has been the key specialist guiding indigenismo: "he can understand indigenous cultures and point out the routes of action that are deemed acceptable for the communities, and can thus achieve the goals of the dominant society with the least amount of conflict and tension possible. In other words, the anthropologist is an expert in manipulating Indians." ${ }^{\circ 86}$ Although Bonfil Batalla agrees with Warman that the anthropologist has become a bureaucrat servicing the interests of the state through the accumulation of knowledge of indigenous communities, he is more idealistic in his conclusion. He argues that the role of anthropologists and intellectuals in general should be the critical analysis of dominant societies and their unequal structures. ${ }^{587}$ For him, the miserable and impoverished circumstances of indigenous peoples should be the starting point for this critique. He further comments that the critical analysis of society is important for the creation of utopia, which he defines as "imagining new and better ways of doing things, of doing life." ${ }^{588}$ In the final section entitled "Toward a Plan for Social Anthropology in Mexico," Bonfil Batalla sketches the revisions Mexican anthropology as a discipline must undergo, which include becoming more rational, structured, critical and independent, in order to better fulfill its "social commitment" to liberate all peoples. ${ }^{589}$ It is interesting to note that

\footnotetext{
586 Ibid.

${ }^{587}$ Ibid., 61-62.

588 Ibid., 63.

589 Ibid., 65.
} 
while he is critical of his predecessors, Bonfil Batalla continues to perpetuate the notion that anthropology is a profession integral to the welfare of the Mexican nation.

In the third essay entitled "Applied Anthropology in Mexico and its Final Destination: Indigenismo," Margarita Nolasco Armas offers a strong critique of the relation between anthropology and indigenismo. She discusses many of the arguments previously outlined in the first two essays to the point that the anthology starts to feel repetitive, but no less powerful. For example, she argues that "the acculturation and integration of indigenous peoples became the main occupation of social anthropology" in Mexico. ${ }^{590}$ Anthropology's narrow and almost obsessive focus on the "Indian question" then led to the neglect of other important national problems, such as urban development, agriculture, education, public health and so on. Nolasco Armas views applied anthropology as synonymous with indigenismo and as a tool of domination: "Applied anthropology - indigenismo - has always been a colonialist anthropology intended for the knowledge - and the consequent use - of the dominated." ${ }^{591}$ She is critical of the indigenista studies that emerged in the 1940s and 50s for being merely descriptive and for having positioned indigenous peoples as isolated from the mestizo world, thereby ignoring the colonial relations of exploitation that characterize their lives. ${ }^{592}$

Nolasco Armas further criticizes indigenismo for its lack of reflexivity, for not questioning its raison d'être: why do indigenous peoples and cultures have to be changed in the first place? She remarks that indigenismo has been so determined to integrate indigenous peoples into national society, with the ultimate goal of eliminating cultural

590 Ibid., 67.

591 Ibid., 72, 74.

592 Ibid., 75-76. 
differences and achieving homogeneity, that it has not paused to consider the real causes of their marginalization. As such, she observes, "indigenismo can be said to be part of a system of domination that seeks to maintain indigenous peoples subjugated. ${ }^{\prime 593}$ Similar to Bonfil Batalla, Nolasco Armas concludes by stating that a critical and socially committed anthropology is necessary to understand the country's asymmetrical relations of power and to begin proposing alternatives. ${ }^{594}$

The last two essays turn their attention to critiquing Mexico's National Institute of Anthropology (INAH) and the School of Anthropology (ENAH). In the essay entitled "Some Issues with the Current Anthropological Research," Mercedes Olivera provides a detailed analysis of the INAH. She notes that while the INAH is the official entity responsible for disseminating anthropological knowledge in Mexico, "this responsibility has only been partially fulfilled." ${ }^{595}$ Of particular concern for Olivera is the lack of resources dedicated to research. She comments that despite the fact that the Institute's budget has been increased 100 percent in the past ten years, only five percent is dedicated to research. The rest of the budget is set aside for "the conservation of historical monuments and to the circulation of anthropological materials in museums, archeological places and costly publications.. ${ }^{596}$ The breakdown of the INAH's budget is telling because it underscores that the only indigenous peoples accorded importance and worth in the Mexican nation are those who belong to the dead civilizations of the past. The valorization and preservation of the past in turn serves to negate the presence of indigenous populations in contemporary Mexico.

${ }^{593}$ Ibid., 83.

${ }_{594}^{59}$ Ibid., 90-91.

595 Ibid., 95.

${ }^{596}$ Ibid., 97. 
Olivera points out that in addition to its small and poorly administered budget, anthropological research has been compromised by its institutionalization. She notes, "Institutionalization has not only limited but directed anthropological research toward the goals and interests of the governmental elite." ${ }^{597}$ Moreover, Olivera notes that an excessive dependency on the theories and methodologies of Anglo American anthropology has resulted in the arrested development of Mexican anthropology, which has been incapable of properly addressing the country's distinct problems. She concludes along the same lines as Bonfil Batalla and Nolasco Armas, calling for the need to create a critical and independent anthropology. She observes that Mexican anthropology, characterized by bureaucratic and old institutions, lack of resources, structural disorganization and so on, needs to be reformed before it can fulfill its social function of critique. $^{598}$

In the final essay entitled "The Training of New Anthropologists," Enrique Valencia offers similar arguments to those of Olivera. For example, he views the INAH as a bureaucratic institution overwhelmed by a series of obligations and responsibilities that drain its budget: "In effect, the tasks of conservation and administration of an artistic and historical patrimony...constitute a considerable reduction and hindrance to [the Institute's] scientific work." ${ }^{599}$ He further notes that the ENAH, previously the most important school for the training of anthropologists across Latin America, has become "a mere administrative appendage to the Institute, without autonomy or internal

${ }^{597}$ Ibid., 109.

${ }^{598}$ Ibid., 116-117.

599 Ibid., 146. 
dynamics. ${ }^{9600}$ Much like Olivera, Valencia argues that the influence of Anglo American anthropology, indigenismo and nationalism have all hampered the development of Mexican anthropology. For Valencia, Mexican anthropology must become "modernized" and "professionalized" if it wants to recover its scientific vocation. ${ }^{601}$ The terms "modern" and "professional" remain elusive here since he does not elaborate on their definition or on how this new anthropology might be established in Mexico. In his conclusion, Valencia observes that anthropology's reputation has suffered due to the profession's bureaucracy and unproductivity. However, he reassures himself and his colleagues of their profession's importance by stating that anthropology is the one social science that can provide "knowledge and solutions to the country's structural problems.. ${ }^{{ }^{002}}$ Valencia here reproduces the notion that anthropologists are especially equipped to understand indigenous peoples and society in general.

The publishing of De eso que llaman antropología mexicana was not without controversy and culminated in the expulsion of Bonfil Batalla from the ENAH by director Ignacio Bernal. ${ }^{603}$ Similarly, Olivera was fired from the INI in 1972 because her plan to promote ethnic and class consciousness among indigenous communities in Chiapas proved threatening to the integrationist goals of the Mexican state. ${ }^{604}$ These expulsions highlight that a number of anthropologists remained loyal to the government and its conservative indigenista policies. This is evident, for example, in the monograph entitled Balance del indigenismo (Balancing Indigenismo, 1977), written by the

\footnotetext{
${ }^{600}$ Ibid.

${ }^{601}$ Ibid., 141-143.

602 Ibid., 152.

${ }^{603}$ Lomnitz, Deep Mexico, Silent Mexico, 232.

${ }^{604}$ Giraudo and Lewis, "Pan-American Indigenismo (1940-1970)," 9.
} 
anthropologist Alejandro Marroquín and published by the Inter-American Indigenous Institute. While Marroquín acknowledges the criticisms that posit official indigenismo as paternalistic and colonialist, he defends its policies for having made "positive contributions" to Mexican society. ${ }^{605} \mathrm{He}$ views indigenismo as having made "enormous progress in the path toward man's own liberation." ${ }^{606}$ His loyalty is further evident in his reproduction of the image of indigenistas as benefactors of indigenous peoples and as promoters of development. For instance, he argues that indigenistas are the natural "advocates of the Indian" 607 and that indigenous peoples are in need of "an external agent that drives and helps them in the process of self-improvement." ${ }^{908} \mathrm{He}$ also notes that despite its faults, indigenismo is full of good intentions: "indigenismo is an extreme thesis with an abundant dose of naïve emotion." ${ }^{609}$ The use of the words "naïve" (from Old French naïf, meaning "natural," "genuine" or "innocent") and "emotion" (from Old French emouvoir, meaning to "stir up" strong feelings) to describe the politics of indigenismo is peculiar, but serves to legitimize the role of indigenistas in Mexican society because it frames their policies and practices as being the result of strong emotions and the desire to make the world a better place.

The contrasting opinions on De eso que llaman antropología mexicana and Balance del indigenismo underline the fact that indigenismo has never entirely been a monolithic project. However, any student of anthropology might be uncomfortable to learn that the authors of De eso que llaman antropología mexicana and other members of

${ }^{605}$ Marroquín, Balance del indigenismo, 287.

606 Ibid.

607 Ibid., 21.

608 Ibid., 17.

${ }^{609}$ Ibid., 14. 
the 1968 movement were co-opted into the state's institutions. Most disappointing is perhaps Warman's professional trajectory. While Warman dedicated his early career to writing damning critiques of Mexico's indigenista and agrarian policies (see Los campesinos, 1972), in 1992, he accepted the post of Secretary of Agrarian Reform under the neoliberal administration of Carlos Salinas de Gortari (1988-1994). Warman was one of the chief architects of the privatization of the ejido, which sought to incorporate Mexican peasants and indigenous peoples into capitalist modes of production. ${ }^{610} \mathrm{With}$ the advent of neoliberalism and the dismantling of the ISI model of development, indigenous identity gained more visibility and became a viable political subjectivity - how this unfolded in the 1990s is a topic for discussion in the next chapter. In the next section, I turn my attention to exploring how Televisa's educational telenovelas amplified the state's development policies.

\section{Educational Telenovelas}

From 1975 to 1982, Miguel Sabido produced seven educational telenovelas for Televisa. Scholars have noted that educational telenovelas were in part the result of the pressure Televisa received from the Mexican government to improve the quality of its programming and to reorganize it along more socially responsible lines - having already been forced to cancel 35 programs deemed "offensive" because of excessive violence and sex in $1971 .{ }^{611}$ However, this is not to suggest that Sabido was a mere puppet of party politics. According to journalists Claudia Fernández and Andrew Paxman, Sabido was a

\footnotetext{
${ }^{610}$ González, "From Indigenismo to Zapatismo." Hernández Castillo, Histories and Stories from Chiapas. Lomnitz, Deep Mexico, Silent Mexico.

${ }^{611}$ Heidi N. Nariman, Soap Operas for Social Change: Toward a Methodology for Entertainment-Education Television (Westport, CT: Praeger Publishers, 1993). Arvind Singhal and Everett Rogers, Entertainment-Education: A Communication Strategy for Social Change (Mahwah, NJ: Lawrence Erlbaum Associates Publishers, 1999).
} 
leftist in a conservative medium who believed in the power of melodrama to impart positive social messages ${ }^{612}$ Having been educated in the humanities at the UNAM and trained in theater, Sabido joined television in the 1960s. One of his first endeavors included writing and producing four historical telenovelas from 1967 and 1970 that celebrated Mexican history. In 1974, he became vice president for research at Televisa and director of its channel 9, a commercial-free station devoted to cultural programming. The year 1974 also marked the creation of the Mexican Institute of Communication Studies (IMEC), which was designed to investigate the social uses of television by experimenting with various formats, such as news and games shows. The IMEC provided a suitable space for Sabido to begin devising his theory-based, entertainment-education strategy that was to influence all of his telenovelas, with the help of his sister Irene, a teacher and Televisa producer.

The entertainment-education strategy can be defined as the intentional placement of educational messages in entertainment programming. ${ }^{613}$ An entertainment-education telenovela is thus a melodramatic series that seeks to convey an educational theme to promote some aspect of national development, without sacrificing its commercial appeal. ${ }^{614}$ The entertainment-education telenovela format consists of providing positive, negative and doubtful role models, who illustrate how certain actions can be rewarded

612 Fernández and Paxman, El tigre, 204.

613 Singhal and Rogers, "A Theoretical Agenda for Entertainment-Education," Communication Theory, 2 (2002): 117-135.

614 Nariman, Soap Operas for Social Change. 
and others punished, in order to teach viewers and encourage them to change their behavior accordingly. ${ }^{615}$

The program that influenced Sabido's entertainment-education methodology was the Peruvian telenovela Simplemente María, which became a sensation across Latin America in 1970. The plot of the telenovela is a basic one: the titular character is a humble peasant from the Andes who migrates to the capital city of Lima to search for better opportunities. After María starts working as a domestic for a rich family, she is seduced by her employer Roberto and gets pregnant. Roberto then abandons her for a woman of his own socioeconomic status. In order to take care of herself and her child, María learns how to read, write and sew. She starts to make and sell her own clothes and eventually becomes a famous fashion designer. The fact that María achieved her success while using a Singer sewing machine led to a dramatic increase in the sales of this brand in Peru. Moreover, the telenovela inspired a rise in the number of enrollments in literacy and sewing classes. Fernández and Paxman observe that Simplemente María taught two main lessons: it demonstrated that audiences were interested in storylines that chronicled the journey of poor women who could reach upward mobility through their own hard work and efforts, without being dependent on men; it also showed that telenovelas, by mixing their melodramatic elements with a dose of social realism, could have "a tangible positive impact on the behavior of their viewers." 616 The unprecedented success of Simplemente María came at a time when Latin American intellectuals derided telenovelas

${ }^{615}$ Manon Parry, Broadcasting Birth Control: Mass Media and Family Planning (New Brunswick, NJ: Rutgers University Press, 2013). Arvind Singhal et al., "Reconstructing the Story of Simplemente María, the Most Popular Telenovela in Latin America of All Time," Gazette, 54 (1994): 1-15.

${ }^{616}$ Fernández and Paxman, El tigre, 138. 
and television in general for "dumbing down" the public. Simplemente María's celebration of education and idealization of single working mothers provided an important counterargument to intellectuals. ${ }^{617}$

Sabido's most important contributions to Mexican television were his telenovelas Ven conmigo (Come with Me, 1975-76) and Acompáñame (Come along with Me, 1977-78). The first telenovela was designed to promote the SEP's adult literacy program. Following the entertainment-education methodology, the "good" characters in this telenovela were those who were willing and eager to participate in the program and the "bad" ones were those who rejected it. The telenovela featured an epilogue at the end of each episode that listed the SEP's address to remind viewers where they could enroll. Ven conmigo was both a commercial and social phenomenon. The telenovela exceeded its ratings expectations at the same time that it contributed to the increase in the number of enrollments in the SEP's program. In 1976, for example, the SEP registered one million new students - a 63 percent increase from the previous year. ${ }^{618}$

The telenovela Acompáñame was more daring as it tackled the thorny issue of family planning. Conservative sectors like the Catholic Church continued to oppose family planning in the 1970s. However, the Mexican government at this time reversed its long-held pronatalist policy, which had restricted access to contraception, and announced that family planning was the basic right of all citizens in order to curtail the country's unbridled population growth. In 1972, the Echeverría administration launched a national family planning program financed by the United Nations Fund for Population Activities;

617 Ibid.

618 Singhal et al., "Reconstructing the Story of Simplemente María." Singhal and Rogers, Entertainment-Education. 
it also invited members of the Mexican Association of Public Relations to the National Publicity Council to compete for a contract to develop family planning campaigns. ${ }^{619}$ Historian Manon Parry notes that the winning campaign, "Vámonos haciendo menos" (Let's Become Fewer), was effective to the extent that it encouraged new gender roles, but was problematic because it reinforced racial, class and gender divisions. The campaign, for example, reproduced the incorrect assumption that poor people have many children because of their cultural and religious traditions. Overall, the campaign failed to address the role of structural inequalities in perpetuating poverty and instead focused on changing individual behavior. ${ }^{620}$ The telenovela Acompáñame for its part was designed to support the newly established National Center for Family Planning (CNPF), to provide information about family planning methods and free government clinics, and to motivate viewers to use contraception. Similar to the previous educational telenovela, Acompáñame featured an epilogue at the end of each episode that listed the telephone numbers of the CNPF and other information centers. Acompáñame proved to be another social phenomenon. The broadcast of the telenovela led to a 33 percent rise in the number of visits to the government clinics, a 23 percent increase in contraceptive sales and a 34 percent decline in the rate of population growth from 1977 to $1986 .{ }^{621}$

Despite the success of educational telenovelas in amplifying national development goals, Sabido was not beyond criticism. Parry observes that his entertainment-education strategy raised ethical concerns, including "the point that the deliberate blurring of fantasy and reality may create disappointment among viewers who

\footnotetext{
${ }^{619}$ Parry, Broadcasting Birth Control, 117.

${ }^{620}$ Ibid., 118.

${ }^{621}$ Fernández and Paxman, El tigre. Nariman, Soap Operas for Social Change. Singhal and Rogers, Entertainment-Education.
} 
cannot achieve the same results as the characters they identify with in their romantic relationships or careers." ${ }^{\prime 22}$ Other critics argued that Sabido's strategy could be misused to influence audiences for negative ends. Sabido was further criticized for his seeming exploitation of Televisa's "commercial excesses" and for giving Mexico a bad reputation by portraying its chronic poverty. ${ }^{623}$ While the educational telenovela format reached its peak in the 1970s, Sabido continued to experiment with it in subsequent decades. For example, he promoted sexual health and education for teenagers in the 1981 telenovela Caminemos (Let's Walk Together), and collaborated with UNICEF to raise awareness about homelessness in the 1997 telenovela Los hijos de nadie (Nobody's Children). Simplemente María (1989) ${ }^{624}$

The central plot of this version of Simplemente María remains faithful to the Peruvian telenovela: María (Victoria Ruffo) migrates from the countryside to Mexico City and finds a job as a domestic worker, only to be seduced and abandoned by her boss Juan Carlos (Manuel Zavala) after she gets pregnant. María then attends literacy and sewing classes and becomes a successful fashion designer. However, it is interesting to note that this telenovela is less didactic and more melodramatic than the original. For example, there are no informative epilogues at the end of each episode. Moreover, while María is shown to be learning how to read and write, these scenes are brief and the

\footnotetext{
${ }^{622}$ Parry, Broadcasting Birth Control, 124.

${ }^{623}$ Ibid.

624 The 1989 Mexican version of Simplemente María is its fifth adaptation, having been previously released in Argentina on two separate occasions (1967, 1980), Peru (1969) and Venezuela (1972). Simplemente María was adapted again in Mexico in 2015, which attests to the popularity and longevity of this rags-to-riches storyline. The main reason for choosing to analyze the 1989 version instead of the abovementioned telenovelas from the 1970 s is the lack of access - Televisa's materials prior to the 1980s have not been digitized.
} 
emphasis is placed on her romantic relationship with her teacher Víctor (Jaime Garza).

After María becomes a rich and famous designer, the plot also becomes excessively convoluted: María loses her memory after a car accident, her children are kidnapped, she is tortured multiple times by the cartoonish villain Lorena (Gabriela Goldsmith), she has four different love interests and so on.

The social realism and educational elements that made Simplemente María a sensation across Latin America in 1970 are virtually absent from the Mexican version of the telenovela, which was written and produced by the Chilean expatriate Valentín Pimstein. Fernández and Paxman remark that Pimstein understood the appeal of the Cinderella storyline better than any other producer in Mexico. He made a career out of creating simple telenovelas that emphasized romanticism over social themes, espoused a Manichean vision of the world, featured stereotypical settings (the humble barrio of the heroine and the mansion of her lover) and characters (the abnegated mother and the virginal heroine), and provided hope through the gratification of a happy ending. ${ }^{625} \mathrm{~A}$ staple of his telenovelas is the cultural transformation of the female protagonists, which I consider to be a form of whitening. For example, the opening credits of Simplemente María (see Appendix A) depict the eponymous character as a humble peasant dressed in traditional clothing (sandals, braids, long skirt and a rebozo) and going about her daily activities (milking cows and washing clothes in the river) in her picturesque town that remains unnamed. The theme song for its part describes María as a beautiful woman capable of overcoming adversity: "María is the most beautiful/with her love of life/she will triumph." After María settles in the capital city, she learns to speak what is deemed

${ }^{625}$ Fernández and Paxman, El tigre, 124. 
proper Spanish and loses her countryside accent. Once she achieves success as a designer, she is depicted as wearing elegant dresses and suits, ornate jewelry and straight hair; she resides in a large house and vacations in Europe.

While María's journey may have mirrored the aspirations of many viewers, especially women and migrants, it is also problematic. The 1989 version of Simplemente María embraces the logics of neoliberalism, which place the burden of success on the individual and ignores how structural factors operate to impede the upward mobility of some. Moreover, María's journey of becoming a respected member of the upper class, and thus culturally whitened, compounds the message that any trace of indigenousness must be erased before she can become a full citizen integrated into the Mexican nation. The treatment of María's ethnic roots is also telling. María is described throughout the telenovela as a peasant rather than an indigenous woman, but viewers learn that she might be of indigenous descent when she begins creating her soon-to-be celebrated clothing line that includes traditional huipils (embroidered shirts). Her fashion show in Paris features an array of white models wearing these huipils and colorful ribbons on their braids, as María receives a standing ovation for her unique fashion choices. The telenovela reproduces the view that indigenousness is valuable to the extent that it adds an element of folklore and exoticness to national culture, which can then be exported for consumption on a global scale.

Simplemente María set the precedent for Pimstein's immensely popular telenovelas of the 90s, all bearing the name María (see Appendix B): María Mercedes (1992-93), Marimar (1994) and María la del barrio (1995-96). The Marías of these three telenovelas achieve success not through their own efforts and hard work but through their 
beauty, virginal innocence and the help of a male benefactor who guides their cultural transformation. Each telenovela features a montage of María learning what to wear, how to walk, how to behave at the dinner table, and how to speak properly and with the right accent, which underlines that education here is not so much about attending school to acquire literacy, but about learning to embody the qualities of whiteness. The end goal of María's education is to transform her into a respected member of the upper class so that she can please her love interest. As María explains in María la del barrio, "Quiero convertirme en todo una dama pa' que el se sienta orgullosa de mi..." ("I want to become a lady so that he feels proud of me"). Moreover, the fact that the Marías have to correct their speech, which the actress Thalía peppered with typical slang ("chale," "qui hubo," "rete chido," etc.) and exaggerated to mirror (or parody?) that of the working classes, points to how popular speech in Mexico is framed as peculiar and even endearing, but ultimately deficient. The standard Spanish of the middle classes remains the norm against which all other speech and accents are judged as inappropriate. In short, it is a lesson on speech, manners and propriety that propels the Marías into the civilized and white world.

The fact that the Cinderella scheme replaced the entertainment-education model and became the standard narrative of Mexican telenovelas from the 1980s onward parallels the rise of neoliberalism in the country - both nurture the hope that people's hardships and struggles will be rewarded in the future, thereby trapping them into a never-ending cycle of aspiration. Furthermore, the repetition of the rags-to-riches narrative central to the Cinderella scheme serves to frame Mexico as a land of opportunity where upward mobility is possible. The success of the Marías in bridging the 
class divide by simply correcting their social deficiencies can be read as an allegory of the nation, of Mexico overcoming its obstacles (mainly poverty) to obtain progress and modernity.

\section{Conclusion}

In this chapter, I explored Mexico in the 1970s through the lens of indigenismo and educational telenovelas. The policies of the Echeverría administration breathed new life into indigenista theory and practice, as evident in the plethora of publications, conferences and programs that emerged to offer critiques and solutions on how to reformulate indigenismo and how to best apply it to the national problems. A discussion of indigenismo is important because, alongside mestizaje, it "continues to be one of the overarching discursive frameworks for understanding the politics of difference" in Mexico and Latin America in general. ${ }^{626}$ Saldívar argues that indigenismo has been a crucial part of mestizaje's racial ideology. Indigenismo has served to position indigenous peoples as an "other" and as an object to be redeemed by the state, which identifies as mestizo. ${ }^{627}$ Indigenismo is a set of discourses, policies and practices that not only work to define the indigenous as a group that needs to be developed and incorporated into the nation but it helps to delineate "the identity of the mestizo - state - as the redeemer and promoter of development." 628 In other words, the mestizo needs the "Indian other" in order to define himself. Mestizo and "Indian" are thus two sides of the same coin.

While I examined indigenismo mainly through an analysis of De eso que llaman antropología mexicana, I do not intend to suggest that indigenismo is a monolithic or

${ }^{626}$ Saldívar, "Everyday Practices of Indigenismo," 84.

${ }^{627}$ Saldívar, Prácticas cotidianas del estado, 176.

${ }^{628}$ Ibid. 
unified intellectual endeavor. In fact, I pointed out that the publication of De eso que llaman antropología mexicana led to the expulsion of Bonfil Batalla and others from the ENAH, which underscores that a range of voices, opinions, attitudes and relationships have constituted indigenismo. I also discussed the role of telenovelas in promoting national development goals, in particular literacy and family planning methods, in order to underscore the fact that popular culture does not exist in a vacuum insulated from the politics of the state. While no other television producer worked as closely with governmental agencies as Sabido did in the 70s, telenovelas have become adept at (re-) producing national ideological fictions. The relation between neoliberal ideologies, the state and popular culture is a topic for discussion in the next chapter. 


\section{Appendix A}

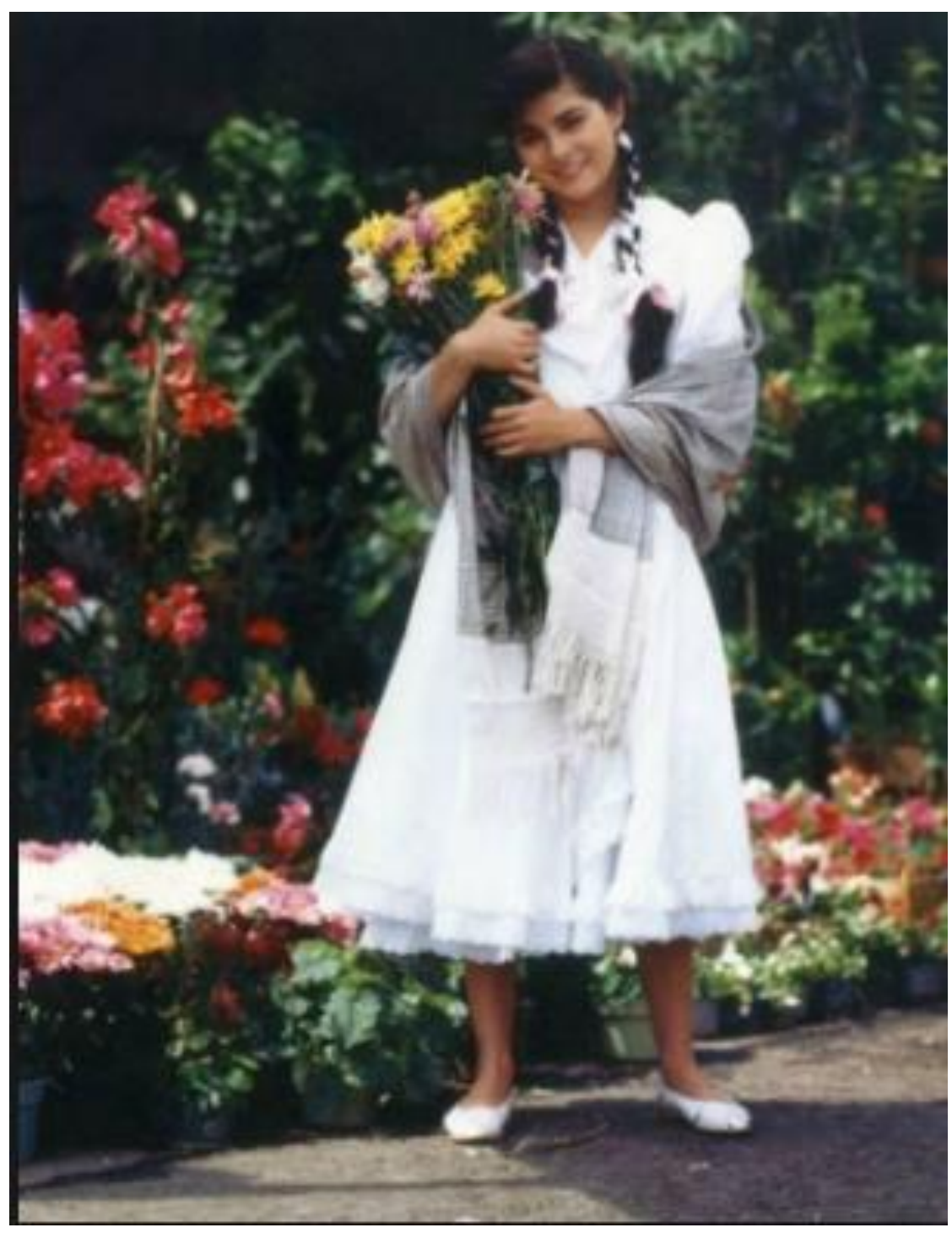

Retrieved from: http://www.zeleb.mx/n/confirmado-claudia-alvarez-es-simplementemaria-013525/amp (accessed May 30, 2017). 
Appendix B
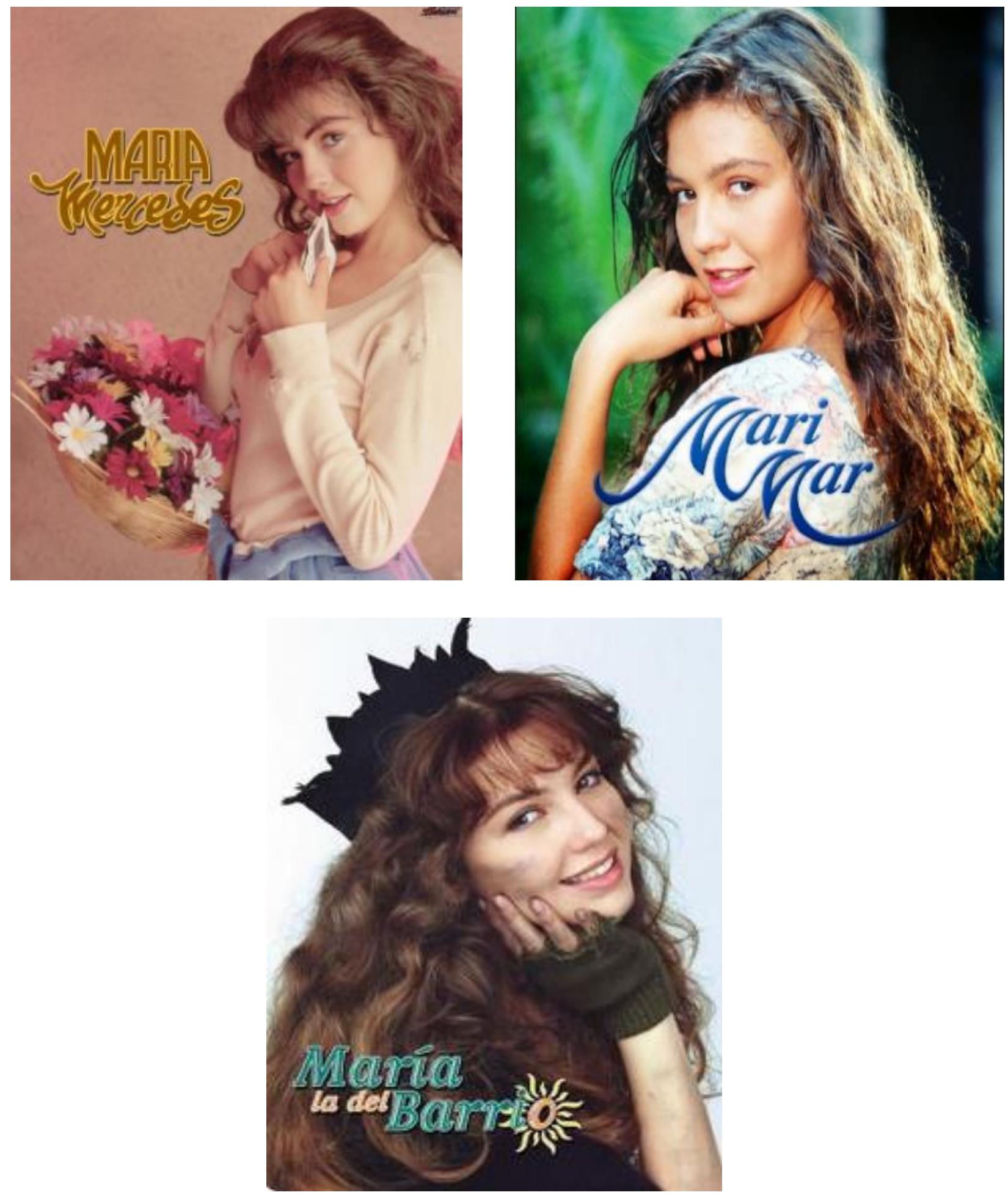

Retrieved from: https://www.pinterest.com/pin/356488126728891503/ (accessed May 30, 2017). 


\section{Chapter Seven}

\section{From Mestizo to Multicultural: Debating National Identity in Neoliberal Mexico}

Mexico in the 1990s is of significance for the nature of this project because of the shift in revolutionary nationalism - long based on the mestizaje ideology - that led the state to embrace the language of diversity and of cultural plurality. An example of this is President Carlos Salinas de Gortari's campaign slogan, "Que hable México" (Let Mexico speak). According to anthropologist Claudio Lomnitz, this nationalism was "based on the recognition and approval of a certain state-guided diversity," and as such was "better suited" to the neoliberal principles of "free enterprise, weaker state intervention and an open international market." ${ }^{962}$ These neoliberal policies were framed as leading the country to the coveted First World status. In this chapter, I provide a historical account of the concurrent rise of neoliberalism and multiculturalism to explore how indigenous identity emerged as a viable political subjectivity. I am further interested in exploring how indigenous peoples were represented across different media platforms at a time when the question of indigenous rights and culture was central to the political agenda in Mexico.

Influential Mexican intellectuals, such as Roger Bartra, in the 90s began to question the value of revolutionary nationalism, which seemed to be at odds with neoliberalism and the transition to democracy. For example, he noted that official nationalism had become the symbol of an authoritarian regime that had failed to establish a stable economy ${ }^{630}$ President Salinas in particular sought to distance himself from the

${ }^{629}$ Lomnitz, Exits from the Labyrinth, 11.

${ }^{630}$ Gavin O'Toole, The Reinvention of Mexico: National Ideology in a Neoliberal Era (Liverpool, UK: Liverpool University Press, 2010), 135. 
legacy of revolutionary nationalism, such as the corporatist state, evident in his eradication of Article 27 and the subsequent privatization of the countryside (discussed below). However, Salinas "elevated nationalism to a core position in his discourse"631 because he was aware of its role in providing legitimacy to his party. ${ }^{632}$ In fact, writing for the Mexican literary/political journal Nexos in 1990, Salinas asserted that the essence of his reforms were to "return to the original spirit of the 1917 Constitution..." ${ }^{633}$ Hence, the implementation of neoliberal reforms depended to a certain extent on revolutionary legitimacy.

A central component in the redefinition of nationalism was the shift from a politics of mestizaje, associated with cultural homogeneity and assimilationist policies, to multiculturalism. Mexican anthropologist Marta Turok observed that inequality, among other factors, had led to a reexamination of official mestizaje and to a debate between the state and civil society on the multicultural nature of the nation. She argued that the recognition of multiculturalism would open up a space "for the direct intervention of the popular groups in the decisions that affect their interests, [which] are ways of giving democracy and participation value..." ${ }^{\prime 634}$ thereby explicitly linking multiculturalism to the processes of democratization and modernization. Salinas himself made connections between democracy, modernization and neoliberalism in the above-mentioned Nexos

631 Ibid., 55.

${ }^{632}$ The ruling party in Mexico from the time of the Revolution until 2000 has been the Institutional Revolutionary Party (PRI). As sociologist Gerardo Otero points out, the name and the fact that its emblem shares the colors of the Mexican flag have contributed to the image of "the PRI and the state as a single entity" (Neoliberalism Revisited: Economic Restructuring and Mexico's Political Future [Boulder, CO: Westview Press, 1996], 11).

${ }^{633}$ Salinas, "Reformando al estado," Nexos, April 1, 1990, accessed March 15, 2015, http://www.nexos.com.mx/?p=5788. ${ }^{634}$ Quoted in O'Toole, The Reinvention of Mexico, 67. 
article. Here he pointed to the "amplification of our democratic life" and to the "elevation of the population's well-being" as core tenets of modernization in Mexico and the subsequent state reforms. It is worth noting that he avoids the use of the term "neoliberalism" and favors a more populist rhetoric. For example, he concludes the article by stating: "My commitment is with a modernization that is nationalist and popular - in defense of sovereignty and the promotion of justice." However, as this chapter seeks to demonstrate, this rhetoric is not rare given the type of multiculturalism that emerged in Mexico in this decade and that was championed by the Salinas administration (1988-1994), which was not opposed to neoliberalism, but was closely connected to it.

Amid the revision of nationalism, Salinas declared Mexican culture integral to the “"reaffirmation of national identity' and to promote the country's image abroad."635 Shortly after taking office, he founded the National Council for Culture and Arts (Conaculta) in December 1988. One of its core principles was the "assertion in policy that Mexico was a nation, first and foremost, because of its culture." ${ }^{936}$ The responsibilities of Conaculta included correcting the negative image of Mexico - long associated with drug trafficking, corruption and political violence - in order to attract direct foreign investment and to organize high profile exhibitions abroad that could display different aspects of the country. A case in point was Mexico: Splendors of Thirty Centuries, the largest exhibition devoted to ancient, colonial and modern Mexican art to have been assembled in the United States. It premiered at the Metropolitan Museum of Art in New York in 1990 and then traveled to the Los Angeles County Museum of Art

${ }^{635}$ Ibid., 66.

${ }^{636}$ Ibid. 
and to Monterrey, Mexico in 1992. Literary studies scholar Claudia Schaefer notes that the way in which the exhibition was assembled "around the unifying concept of the alleged splendors" of the country, "insinuated a narrative continuum, a totalizing story of unbroken Mexican cultural threads woven across time and space, whose mythos represents the basis and overt legitimation of modern Mexico." ${ }^{\circ 37}$ A major financial contributor to the exhibition was the media tycoon Emilio Azcárraga Milmo, owner and CEO of Televisa until his death in 1997. As the Los Angeles Times reported, the staging of the exhibition coincided with the efforts of Salinas to "raise Mexico's international profile and integrate the country into the world economy." As "one of Mexico's top salesmen,” Azcárraga was best suited to sell culture at home and abroad. ${ }^{638}$ Historian Alex Saragoza asked rhetorically in the same article, "[the government] sense[s] the need to rehabilitate Mexico's image, and who better to do it than Televisa?"

I note the involvement of Televisa in the exhibition and its relationship with the government ${ }^{639}$ to emphasize the major role it has played in shaping Mexican national culture. Journalists Claudia Fernández and Andrew Paxman comment, for example, that Televisa has been a "major influence in the cultural, political and economic attitudes of the majority of the Mexican population. ${ }^{.640}$ Moreover, as the state reduced investment in education and the arts, Azcárraga took it upon himself to protect and disseminate national

${ }^{637}$ Claudia Schaefer, Danger Zones: Homosexuality, National Identity, and Mexican Culture (Tucson, AZ: The University of Arizona Press, 1996), 81.

${ }^{638}$ Marjorie Miller and Juanita Darling, "El tigre: Broadcasting Baron Emilio Azcárraga Monopolizes Mexican Culture and Controls the News. Now He's Stalking the US," Los Angeles Times, November 10, 1991, accessed February 20, 2014, http://articles.latimes.com/1991-11-10/magazine/tm-2187_1_emilio-azcarraga. ${ }^{639}$ Azcárraga was not shy about this relationship, stating that "Televisa considers itself part of the government system and as such supports the PRI" (Miller and Darling, "El tigre").

${ }^{640}$ Fernández and Paxman, El tigre, 34. 
culture on a mass scale through his museums and educational programming. For these reasons, the primary texts of interest here are related to Televisa. In the next section, I provide an account of the emergence of multiculturalism in a neoliberal setting. In the second section, I explore the relationship between leading intellectual Enrique Krauze and Televisa, and their re-vision of history, through an analysis of his book Biography of Power: A History of Modern Mexico, 1810-1996 (1997) and the telenovela El vuelo del águila (The Flight of the Eagle, 1994). In the final section, I discuss the anthropologist Guillermo Bonfil Batalla and his book México Profundo (Deep Mexico, 1996), which promoted multiculturalism before it was officially sanctioned, as well as the telenovela María Isabel (1997-98) in order to examine how indigenous peoples are represented.

\section{Multiculturalism in Neoliberal Mexico}

Before mapping the emergence of multiculturalism in Mexico, it is important to engage with the critical scholarship on neoliberalism. Some of the key scholars I borrow from to define neoliberalism include political scientist Wendy Brown, historian Lisa Duggan and literary studies scholar David Eng. ${ }^{641}$ I also draw from the works of Latin American studies scholars Rebecca Overmyer-Velázquez and Charles Hale to develop the notion of neoliberal multiculturalism in the Mexican context. ${ }^{642}$

${ }^{641}$ Wendy Brown, Undoing the Demos: Neoliberalism's Stealth Revolution (Brooklyn, NY: Zone Books, 2015). Lisa Duggan, The Twilight of Equality? Neoliberalism, Cultural Politics, and the Attack on Democracy (Boston, MA: Beacon Press, 2003). David L. Eng, The Feeling of Kinship: Queer Liberalism and the Racialization of Intimacy (Durham and London: Duke University Press, 2010).

${ }^{642}$ Rebecca Overmyer-Velázquez, Folkloric Poverty: Neoliberal Multiculturalism in Mexico (University Park, PA: The Pennsylvania State University Press, 2010). Charles R. Hale, "Rethinking Indigenous Politics in the Era of the "Indio Permitido," NACLA, Report on the Americas, (2004): 16-37. 
Neoliberalism must be conceived as more than an economic doctrine in order to understand its cultural and political effects. According to Brown, neoliberalism is a political rationality and dominant form of governance that is concerned with "extending and disseminating market values to all institutions and social action" (emphasis in original). ${ }^{643}$ Under neoliberalism, the state constructs itself in market terms and is judged accordingly: profitability, efficiency and cost-benefit calculus become the measure of all state practices. ${ }^{644}$ Individuals are expected to be rational and entrepreneurial actors, whose ability for "self-care" is a measure of their "moral autonomy." 645 In this scenario, the state abdicates its responsibility to address and manage social inequalities, which are relegated to the private sphere. Social inequalities then become "'responsibilised' as an individual's moral meritocratic task. ${ }^{, 646}$ In neoliberalism, competition replaces the liberal economic emphasis on exchange as the guiding principle of the market and of social relations between subjects. With competition, "inequality becomes legitimate, even normative, in every sphere." ${ }^{647}$ As Brown observes, neoliberalism frames political society as being composed of "winners and losers" rather than equal subjects, some of whom are "too small to protect" and will inevitably "be cast off or left to perish." "648 Neoliberalism frames success as a matter of an individual's merit and ability to compete and to invest in aspirations for a better future. Individuals operate under the "limiting assumption" that

\footnotetext{
${ }^{643}$ Brown, "Neo-Liberalism and the End of Liberal Democracy," Theory \& Event, 7 (2003): 3 .

${ }^{644}$ Ibid., 5.

${ }^{645}$ Ibid., 7.

${ }^{646}$ Jo Littler, "Meritocracy as Plutocracy: the Marketising of 'Equality' Under Neoliberalism," New Formations, 80 (2012): 66.

${ }^{647}$ Brown, Undoing the Demos, 64.

648 Ibid., 72.
} 
their hard work will be rewarded if they play according to the rules of the market. ${ }^{649}$ The failure to succeed is then attributed to personal and/or cultural deficiencies, which serves to reinforce neoliberalism's notion of neutrality and to ignore systemic inequalities.

What makes neoliberalism so insidious, according to Duggan, is its rhetorical separation of the economic - seen as neutral and technical and thus not subject to accountability or scrutiny - from the realm of politics and culture. Neoliberalism works under the logic of colorblindness to disconnect enduring material inequalities from the legacies of white supremacy. Eng and other scholars ${ }^{650}$ have remarked that colorblindness cedes way to "an abstract community of individualism and merit," 651 in which race is made to be unimportant and irrelevant to law and policies in order to "consolidate modernity's narrative of freedom and progress. ${ }^{652}$ Such working logic depoliticizes and delegitimizes the significance of race as an organizing principle of society - "race always appears as disappearing." ${ }^{653}$ Furthermore, the logic of colorblindness tasks individuals with forgetting and getting over past injuries - those who are unable or refuse to move on are then blamed for blocking the nation's progress.

The fact that a collective indigenous movement emerged in Mexico concurrently with its neoliberal economic reforms seems paradoxical at first glance. However, as

\footnotetext{
${ }^{649}$ Dana-Ain Davis, "Narrating the Mute: Racializing and Racism in a Neoliberal Moment," Souls, 9 (2007): 350.

${ }^{650}$ Alana Lentin and Gavan Titley, The Crises of Multiculturalism: Racism in a Neoliberal Age (London and New York: Zed Books, 2011). Jodi Melamed, "The Spirit of Neoliberalism: From Racial Liberalism to Neoliberal Multiculturalism," Social Text, 89 (2006): 1-24. David Roberts and Minelle Mahtani, "Neoliberalizing Race, Racing Neoliberalism: Placing 'Race' in Neoliberal Discourses," Antipode, 42 (2010): 248-257. Catherine Rottenberg, "The Rise of Neoliberal Feminism," Cultural Studies, (2013): 120.

${ }^{651}$ Eng, The Feeling of Kinship, 3.

652 Ibid., 41.

653 Ibid., 10.
} 
Overmyer-Velázquez notes, it was precisely the neoliberal emphasis on self-reliance and autonomy that granted legitimacy and authority to the "indigenous demands for economic and political self-determination. ${ }^{964}$ Similarly, sociologist Jane Hindley points out that "the issue of indigenous rights was effectively harnessed to the project of modernizing the Mexican state and the broader political context of ensuring neoliberal economic restructuring and regime maintenance. ${ }^{9655}$ Given the Salinas administration's crisis of legitimacy (because of widespread allegations of electoral fraud) and concern for its international image, it became "politically expedient to address the question of indigenous rights. ${ }^{956}$ For example, the government ratified the International Labor Organization (ILO) Convention 169 on the Rights of Indigenous and Tribal Peoples in 1991 and reformed Article 4 of the Constitution in 1992 to officially recognize for the first time the multicultural nature of the Mexican nation. ${ }^{657}$ These reforms had a positive impact at the international level, attracting foreign investment and ensuring accession to NAFTA.

The Salinas administration shifted its nationalist message and appealed to an indigenous Mexican identity in order to rally support for the neoliberal economic policies and to rebut accusations that NAFTA was to bring about the Americanization of Mexico. Moreover, this multicultural rhetoric was useful in masking the fact that neoliberalism

\footnotetext{
654 Overmyer-Velázquez, Folkloric Poverty, 5.

655 Jane Hindley, "Towards a Pluricultural Nation: The Limits of Indigenismo and Article 4," in Dismantling the Mexican State? ed. Rob Aitken at al. (London, UK: MacMillan Press Ltd., 1996), 225.

656 Ibid., 230.

${ }^{657}$ Additional constitutional reforms were made in 2001 to address the more contentious issues of indigenous autonomy and collective rights (Guillermo de la Peña, "A New Mexican Nationalism? Indigenous Rights, Constitutional Reform and the Conflicting Meanings of Multiculturalism," Nations and Nationalism, 12 [2006]: 279-302).
} 
entailed the withdrawal of state protection and provision of social safety nets for the marginal populations, particularly the rural poor and indigenous populations. The state's abdication of responsibility for the poor represented a dismantling of the basic principles of the Mexican Revolution on which the PRI was founded. The Revolution was fought by poor peasants and on behalf of the ideal of equitable land distribution, as stipulated on Article 27 of the 1917 Mexican Constitution. Political scientist Courtney Jung notes that the peasant emerged from the Revolution as the central political actor with privileged access to state resources. Under Article 27, the state was obligated to redistribute land to the rural population in the form of ejidos. The fact that access to land was linked "directly to government patronage" established "strong ties between the peasantry and the PRI."658 However, Salinas' repeal of Article 27, which effectively privatized the countryside, contributed to "the demise of the peasant as the privileged interlocutor of the corporatist state." ${ }^{659}$ These changes gave rise to indigenous identity as a viable and strategic political subjectivity.

The appeal to an indigenous Mexican identity took place within the larger context of the official recognition of multiculturalism. Overmyer-Velázquez points out that Bonfil Batalla and his México Profundo monograph, in which he redefines the Mexican nation in indigenous terms, was a significant influence in the political shift from a politics of mestizaje to multiculturalism. However, she contends that multiculturalism must be scrutinized because "it is not innocent of power." ${ }^{\prime 60}$ In Mexico, multiculturalism is of a populist kind that celebrates cultural differences without challenging the larger structures

${ }^{658}$ Courtney Jung, "The Politics of Indigenous Identity: Neo-Liberalism, Cultural Rights, and the Mexican Zapatistas," Social Research, 70 (2003): 9.

${ }^{659}$ Ibid., 6.

${ }^{660}$ Overmyer-Velázquez, Folkloric Poverty, 17. 
of power: '[multiculturalism] is constructed as 'apolitical,' a unifying discourse based on shared culture" and on a particular and essentialist image of indigenous peoples - the poor indigenous person who resides in an isolated community and practices local traditions. ${ }^{661}$ On the other hand, indigenous peoples who reside in urban centers and work in sectors other than agriculture are dismissed as being inauthentic or even traitors to their communities. ${ }^{662}$ Anthropologist Carmen Martínez Novo points out that the idea that indigenous peoples belong to the countryside and not the city is part of the colonial legacy of "legislation and informal discriminatory practices" that consigned them to the countryside. ${ }^{663}$ The colonial image of the indigenous as rural is pervasive in many Latin American countries despite the growing number of indigenous peoples living and working in cities.

Hale observes that the cultural project of neoliberalism entails "harness[ing] and redirect[ing]" indigenous movements' cultural rights activism, rather than opposing it directly. A way of achieving this "is the strategic deployment of resources, which rewards organizations that promote acceptable cultural rights demands, and punishes the others." ${ }^{\prime 64}$ The Mexican state can then support apolitical indigenous organizations and their folkloric projects, which do not challenge the economic and political status quo, while construing an image of itself as a democratic and progressive entity. The simultaneous reforms of Article 4 and Article 27 and the ratification of the ILO

\footnotetext{
661 Ibid., 18.

662 Ibid., 20.

${ }^{663}$ Carmen Martínez Novo, Who Defines Indigenous? Identities, Development, Intellectuals, and the State in Northern Mexico (New Brunswick, NJ: Rutgers University Press, 2006): 104.

${ }^{664}$ Hale, "Does Multiculturalism Menace? Governance, Cultural Rights and the Politics of Identity in Guatemala," Journal of Latin American Studies, 38 (2002): 488.
} 
Convention 169 and implementation of NAFTA are therefore not contradictory, but are rather two sides of the same neoliberal coin. Hale further comments that neoliberal governance "takes place through the distinction between good ethnicity, which builds social capital, and 'dysfunctional' ethnicity, which incites conflict." ${ }^{665}$ Borrowing from feminist sociologist Silvia Rivera Cusicanqui, Hale notes that the distinction between "good" and "bad" ethnicity engenders a new sociopolitical category known as the "indio permitido" (permitted Indian). This so-called "permitted Indian" serves to legitimate the state, establish boundaries and domesticate indigenous movements. In a similar context, anthropologist Alcida Rita Ramos observes that "well-behaved Indians," that is, those who "reinforce the Western image of the suffering, helpless and noble savage," serve to justify the resources, funding and personnel allocated to their defense. ${ }^{666}$ Ramos calls this imagined Indian a "hyperreal Indian" because s/he is nothing but a fabrication of a model Indian, whose innocence, stoicism and suffering "have won for him the right to be defended" and have made "him deserving of white solidarity." 667

The image of a modern and democratic Mexico built on neoliberal principles began to crumble as early as 1994, with the crash of the peso and the ensuing economic crisis that heightened the extant social and economic inequalities. Otero points out that neoliberalism benefitted the North and the metropolitan area of Mexico City disproportionately to the South, which is the most densely populated region and with the largest number of indigenous peoples, many of whom "still suffer from archaic and social

${ }^{665}$ Hale, "Rethinking Indigenous Politics in the Era of the "Indio Permitido,"” 17.

${ }^{666}$ Ramos, "The Hyperreal Indian," Critique of Anthropology, 14 (1994): 163-164.

${ }^{667}$ Ibid., 161-162. 
power structures." ${ }^{968}$ The North for its part is typically whiter in its racial makeup and enjoys higher standards of living. ${ }^{669}$ The fact that neoliberalism "exacerbated social polarization is in part the result of its sweeping application with little regard for regional diversity." ${ }^{670}$

The schism between the North and the South of Mexico highlights the centrality of race to the neoliberal project. Feminist anthropologist Karen Brodkin notes that race, as much as class, is a relationship to the means of capitalist production. She argues in the US context that the racialization of workers as non-white and thus as less civilized and less moral makes them vulnerable and justifies their economic exploitation. Such "race making" continues to "rest upon occupational and residential segregation," and in turn facilitates the "degradation of work itself." ${ }^{671}$ In the Mexican context, occupational and residential segregation can sometimes allow indigenous peoples to perform their authenticity in order to gain access to resources and to improve their livelihood, which neoliberalism itself threatens. ${ }^{672}$ However, as Martínez Novo points out, southerners (indigenous and otherwise) who migrate to the North generally seek to distance themselves from the indigenous label because of its social stigma that impedes upward

\footnotetext{
${ }^{668}$ Otero, Neoliberalism Revisited, 3.

${ }^{669}$ Historian Gerardo Rénique and other scholars comment that the northern states since the Revolution have been identified in Mexico's racial and national imagination as a repository of whiteness, industrial development and modernity ("Race, Region, and Nation"). Regina Martínez Casas et al., "The Different Faces of Mestizaje: Ethnicity and Race in Mexico," in Pigmentocracies: Ethnicity, Race and Color in Latin America, ed. Edward Telles [Chapel Hill, NC: The University of North Carolina Press, 2014], 36-80). ${ }^{670}$ Otero, Neoliberalism Revisited, 3.

${ }^{671}$ Karen Brodkin, “Global Capitalism: What's Race Got To Do With It?” American Ethnologist, 27 (2000): 245.

${ }^{672}$ Neoliberal reforms affected the agricultural sector the most, which is "the least capitalistically developed sector in the Mexican economy" (Otero, Neoliberalism Revisited, 17). Owners of the previously mentioned ejidos produce at "subsistence or infrasubsistence levels" and are unable to provide for their families (17).
} 
mobility. In her ethnographic study of the North, Martínez Novo shows that northern employers exploit regional differences to justify the fact that southern migrants have lower wages and work and live in worse conditions than other workers. ${ }^{673}$ The idea that northerners are white is also used to discriminate against migrants and to exclude them from the "imagined community" of the North. ${ }^{674}$ Finally, the common racialized assumption that "the North works, the South sleeps, and the Center eats what is produced by the North" encapsulates the cruel logic of neoliberalism. The North is said to be economically prosperous because of its "hard work" and the South is mired in poverty because of its "laziness," conveniently ignoring systemic inequalities.

Neoliberalism was not without its critics and the Zapatista uprising in 1994 in Chiapas was but "the most radical expression of discontent with growing inequality and lack of democracy in Mexico." ${ }^{975}$ However, this type of discontent was nowhere to be seen on Televisa. As the Ernesto Zedillo administration (1994-2000) confronted a crisis of legitimacy following the uprising, Televisa's media empire had "moved to the forefront of the national project through its multiple, converging projections of lifestyles, aesthetics, and consumerism." ${ }^{676}$ Televisa's interests are virtually inescapable. The private conglomerate owns and operates four national channels and is associated with a plethora of businesses, including radio, magazines, recording industry, sports teams and cable. Its four-channel operation is often the only option in television programming for

${ }^{673}$ Martínez Novo, Who Defines Indigenous? 34.

${ }^{674}$ Ibid., 106. The terms "chiapaneco" and "oaxaqueño" (people from the southern states of Chiapas and Oaxaca) are interchangeable with "indio/a" and tend to be used disparagingly in the North to describe people who have dark skin and "look" indigenous, which reflects the low value attached to indigenousness.

675 Otero, Neoliberalism Revisited, 2.

${ }^{676}$ Murphy, "Television and Cultural Politics in Mexico," 255. 
the Mexicans who cannot afford subscription to cable and/or satellite. ${ }^{677}$ The inequalities that neoliberalism has exacerbated are white-washed by Televisa's selective images of a modernized Mexico - visual images of young, beautiful and white individuals overcoming their obstacles, defining their identities and achieving happiness via consumerism abound in advertisements and telenovelas. The state and Televisa have promoted neoliberalism and its implied consumerism as stepping-stones to modernity, eliding the fact that the majority of Mexicans do not have access to what is being sold.

In sum, while multiculturalism and government reforms in the 90 s did in fact open up a space for the grievances of indigenous movements, these were also deployed as mechanisms of "co-option and control within the context of neoliberal adjustment" that served to "maintain the hegemony of dominant elites." 678 In the official transition from a politics of mestizaje to multiculturalism, the state retained the right to legitimate certain indigenous identities and to deny others. The state's definition of indigenous peoples determines how resources are distributed and what actions are taken on their behalf. Therefore, multiculturalism can be understood as a politics of much of the same - a revised mestizaje for the neoliberal era.

\section{The Neoliberal (Re-) Vision of History}

As part of the neoliberal reforms, the Mexican state implemented austerity measures that depreciated real minimum wages in half and affected the educational sector the hardest - public universities in particular. Lomnitz notes that these measures heralded "a new era in Mexican cultural life, an era marked by privatization and by growing

677 Ibid.

${ }^{678}$ Rachel Sieder, Multiculturalism in Latin America: Indigenous Rights, Diversity and Democracy (New York: Palgrave Macmillan, 2002), 199. 
differences between an increasingly proletarianized mass of low-prestige teachers, a somewhat fancier stratum of publishing academics, and a new cultural elite that fuses writing with business. ${ }^{679}$ Leading intellectual Krauze embodies this new cultural elite that has developed strong ties with the state and private enterprise in order to popularize their version of Mexican history.

At the same time that the Mexican state cut funding for public universities, it continued to foster its relationship with intellectuals. The state provided generous contracts and subsidies in order to disseminate neoliberal ideals to those intellectuals associated with the journals Vuelta and Nexos, directed by historians Krauze and Héctor Aguilar Camín, respectively. ${ }^{680}$ Aguilar Camín founded the Cal y Arena publishing house and Krauze for his part received support from the administration of Miguel de la Madrid (1982-1988) for his "biographies of power" series on the presidents and other historical figures of Mexico, which was first printed in 1987 by the government-owned publishing house Fondo de Cultura Económica (the English version with which I engage below was published by HarperCollins a decade later). Latin American studies scholar Ignacio Sánchez Prado comments that these "biographies of power" "set the stage for Krauze's emergence as a visible public intellectual" in the $90 \mathrm{~s} .{ }^{681}$ His writings and ideas reached "an almost unprecedented level of diffusion in the Mexican public sphere, thanks to weekly national television broadcasts and the distribution of popular version of [his]

${ }^{679}$ Lomnitz, Deep Mexico, Silent Mexico, 215.

${ }^{680}$ Chassen-López, "Distorting the Picture," 110.

${ }^{681}$ Ignacio Sánchez Prado, "Claiming Liberalism: Enrique Krauze, Vuelta, Letras Libres, and the Reconfigurations of the Mexican Intellectual Class," Mexican Studies/Estudios Mexicanos, 26 (2010): 69. 
biographies in newsstands across the country." ${ }^{982}$ Moreover, Krauze solidified his relationship with Televisa by becoming co-owner of its publishing house Clio, whose mission statement is to disseminate on a mass scale "the most important events that Mexico has lived throughout its history."

Biography of Power: A History of Modern Mexico, 1810-1996 is a massive anthology of over 800 pages that includes a series of maps, illustrations (mainly of the Mexican leaders Krauze writes about) and a two-page chronological list of events dating from the Aztec empire to the present (in this case, 1996). The book, written in an accessible writing style, is divided into five sections and a total of 26 chapters that deal with the Conquest, Independence, Revolution, the consolidation of the modern state and the present. In the preface, Krauze states that the purpose of his book is to "thread the lives of the most important leaders during the last two centuries into a single biography of power." ${ }^{683} \mathrm{He}$ clarifies that he is "in no way subscribing to an outmoded (and unacceptable) great-man theory of history. What I hope to convey is that in Mexico the lives of these men...had an enormous effect on the directions taken by the nation as a whole." ${ }^{684}$ The fact that he dedicates all of his chapters to profiling how individual men contributed to building the Mexican nation reinforces the great-man theory. Women are nearly absent from Krauze's account of history. To cite but one example, out of the 47 illustrations scattered throughout the anthology, one is of the mythical Virgin of Guadalupe and only two are of real women (Empress Carlota and Sara Pérez, who is

\footnotetext{
682 Ibid.

${ }^{683}$ Krauze, Biography of Power, trans. Hank Heifetz (New York: HarperCollins Publishers, 1997), xv.

${ }^{684}$ Ibid.
} 
unnamed and simply described as the "wife of Francisco I. Madero"). ${ }^{685}$ This erasure of women and their agency in making the nation is characteristic of the treatment of women and indigenous peoples in Mexican history. ${ }^{686}$

Before profiling the great men that made Mexico, Krauze provides an overview of the Conquest and the role of mestizaje in consolidating Mexican nationality. In the first part of the book, entitled "The Weight of the Past," Krauze recycles and states as fact many of the ideas and myths that his intellectual predecessors, such as Andrés Molina Enríquez, Manuel Gamio and José Vasconcelos, had debated at the beginning of the twentieth century. For example, he notes that Mexican nationality was born from the relationship between conquistador Hernán Cortés and Malinche, which produced Martín Cortés, who was the first mestizo and "also the first Mexican." ${ }^{987}$ Note here how the two become equivalent - to be mestizo is to be Mexican and vice versa. Krauze comments that while the process of mestizaje "took centuries," sometime in the nineteenth century, "the mestizos became the majority and the proportion of Indians and whites steadily declined. Martín Cortés had won the battle. ${ }^{, 688}$ In his view, the proliferation of the mestizo population helped eliminate racial animosity in the country. For instance, he remarks, "while the color of one's skin remained, and would always remain, a major factor in Peruvian discrimination, the purely racial problem in Mexican history was largely resolved through mestizaje." ${ }^{" 69}$ Krauze here reveals his privilege, for only a person of white complexion can make the claim that skin color does not matter or make a

${ }^{685}$ Ibid., 258.

${ }^{686}$ Chassen-López, "Distorting the Picture," 106.

${ }^{687}$ Ibid., $51-52$.

${ }^{688}$ Ibid., 52.

${ }^{689}$ Ibid., 54. 
difference in one's life. Moreover, the comparison of Mexico and Peru is a recurring and convenient trope that allows Krauze to deflect Mexico's issues of racism onto its southern neighbor. Peru throughout the chapter is framed as being beset by ethnoracial conflicts, while Mexico, thanks to its successful mestizaje, has become "a vast, dynamic, and largely peaceful laboratory for cultural convergence," ${ }^{690}$ as well as a "multicolored mosaic of customs and traditions." ${ }^{691}$ The image of a happy, peaceful and orderly Mexico aligns with the neoliberal interests of the state and works to delegitimize the very real political, economic and racial injustices that indigenous groups across Mexico were condemning at the time.

Krauze further deploys the mestizaje ideology to explain the rise of the neoZapatistas in southern Mexico. In the final chapter, entitled "The Theater of History," Krauze observes that the Zapatista Army of National Liberation (EZLN) "had apparently come out of nowhere" on January 1, 1994, causing much "surprise and confusion" among the majority of Mexicans who "knew nothing at all about them, neither their origin nor their intentions. ${ }^{9692}$ Situating himself as the interpreter of Mexican public opinion, he ponders: "An Indian rebellion in Mexico, in the age of NAFTA, near the end of the twentieth century? Inconceivable. A guerrilla war in Mexico, when the long, ferocious guerilla war in El Salvador had just ended with the signing of a peace pact in Mexico City? Not possible. ${ }^{" 693}$ Krauze here, more than in any other chapter, comes across as willfully misguided. He fails to contextualize the discontent that had been brewing for years across Mexico because of growing socioeconomic inequalities and instead points

\footnotetext{
${ }^{690}$ Ibid., 56.

${ }^{691}$ Ibid., xiv.

${ }^{692}$ Ibid., 779.

${ }^{693}$ Ibid., 779-780.
} 
out that in the southern states of Chiapas and Yucatán, mestizaje had been less common than in the rest of the country, which accounts for the ethnic wars of the 1700s and 1800s. He continues: "In Yucatán, most of this ethnic tension gradually disappeared during the twentieth century, in the wake of modernization and increased mestizaje. But Chiapas would remain the worst island of shame within Mexico." ${ }^{964}$ Krauze seems to suggest that if mestizaje had been successful in Chiapas, that is, if the numerous indigenous groups had been assimilated into the mestizo population, an indigenous uprising would not have taken place "in the age of NAFTA." This line of argument serves to obfuscate serious systemic issues and to reinforce the dominant structures of power.

Krauze devotes most of the final chapter seeking to delegitimize the EZLN. He is cautious in his critique of President Salinas, with whom he enjoyed a friendly relationship, and targets the EZLN's ideology and its most prominent non-indigenous leader, Subcomandante Marcos, whom he describes as "the voice of a guerrilla of the seventies and eighties who had added indigenismo to his ideological arsenal. ${ }^{\prime 695}$ Krauze seems especially irritated that the Zapatistas mobilized around an ethnoracial identity, which invoked the history of 500 years of oppression in their demands for social justice, because in his mind, "Mexico was an exception to the rule of ethnic discrimination in the Americas...Mestizaje, not ethnic hatred, has been the overriding reality in most of Mexico and modern Mexican history...However, the mestizos of Mexico (which means except for the pure Indians themselves - nearly everybody, including Marcos) maintained an incomprehensible silence about this feature of Mexican history. The rising was

\footnotetext{
694 Ibid., 780.

695 Ibid., 785.
} 
supposed to be a revenge for the Conquest, and that was enough." ${ }^{696}$ To Krauze, mestizaje in Mexico is a fact and such an undeniable reality that it alone invalidates the mobilization around an indigenous identity.

Sociologist Avital Bloch notes that Krauze and his contemporaries of the journal Vuelta were generally hostile to left-wing revolutions and advocated gradual, nonviolent change as preferable. These intellectuals dismissed socialism as a utopian concept and associated a reformed capitalist economy with social liberties and democracy. ${ }^{697}$ According to these intellectuals, the problem in Mexico "was that its radicals were blind to the 'bloody fantasy' of socialism." ${ }^{698}$ Krauze concludes the final chapter by framing the Zapatista rebellion as a limited and unnecessary phenomenon that must be rejected because "there has already been too much blood in Mexican history." ${ }^{699}$ He places his faith in the official system in order to achieve democratic and social change, dismissing other alternatives as illegitimate: "it is in the real theater - the one that most counts, the theater of the PRI on the stage of the nation - that the future of Mexico will be decided" (emphasis in original). ${ }^{700}$ The dismissal of the Zapatista uprising serves to perpetuate the view widespread at the time that indigenous peoples were too submissive and thus easily tricked by outside forces (such as Sub Marcos) into rebelling against the government.

In addition to subsidizing neoliberal publications, such as Vuelta and Nexos, the Mexican state also targeted education and popular culture. Historian Francie Chassen-

\footnotetext{
696 Ibid., 786-787.

${ }^{697}$ Avital H. Bloch, "The Journal Vuelta and the Emergence of Mexican Neoconservatism," in Public Intellectuals in Contemporary Latin America, ed. Rogelio de la Mora et al. (Mexico: Universidad de Colima, 2007), 154.

${ }^{698}$ Ibid., 155.

${ }^{699}$ Krauze, Biography of Power, 793.

${ }^{700}$ Ibid., 794.
} 
López points out that in 1992, then Minister of Public Education Ernesto Zedillo, who was to become president two years later, sponsored a revision of textbooks for the fourth, fifth and sixth grades of primary school, which are distributed gratis throughout the country. These revisions included the minimization of popular heroes like Emiliano Zapata and the vindication of former villains like Porfirio Díaz. ${ }^{701}$ The historical revision of textbooks was not without its critics, who viewed the administration as producing an abridged, superficial and anecdotal version of history in a "propagandistic attempt to think of Mexico in terms of neoliberalism." 702 The government ultimately had to shelve the six million textbooks it had printed and commission new ones.

Historical revisionism in popular culture arrived in the form of a telenovela. El vuelo del águila ${ }^{703}$ was the ambitious biography of liberal dictator Porfirio Díaz, written by Krauze and Fausto Zerón Medina and produced by Televisa, with the support of Conaculta, the National Institute of Anthropology and History (INAH) and the National Institute of Fine Arts (INBA). Although not as popular as the Cinderella telenovelas, historical telenovelas have been a part of Televisa's programming since the 1960s, making a strong return in the 80s and 90s, with Senda de gloria (Path to Glory) in 1987, El vuelo del águila in 1994 and La antorcha encendida (Flaming Torch) in 1996. More recently, Televisa released the 13-episode series Gritos de muerte y libertad (Shouts of

${ }^{701}$ Chassen-López, "Distorting the Picture," 111.

${ }^{702}$ Carrie C. Chorba, Mexico, From Mestizo to Multicultural: National Identity and Recent Representations of the Conquest (Nashville, TN: Vanderbilt University Press, 2007), 20.

${ }^{703}$ The hardly subtle nationalist title refers to the Aztec myth that recounts how an eagle, perched on a cactus with a serpent in its mouth, determined the location where Aztec civilization would flourish. This image sits at the center of the Mexican flag and coins. As Chassen-López observes, Díaz's life in the telenovela was meant to embody "Mexico's Aztec origins (although he was of Mixtec ancestry) and national agency in flight" ("Distorting the Picture," 111). 
Death and Liberty), with the assistance of Krauze, Aguilar Camín and other historians, as part of the bicentennial celebrations in 2010. Latin American studies scholar María Rodríguez Cadena notes that unlike the more popular telenovelas that are cheaper to produce, historical telenovelas require "careful production, archive research, ample funding, a variety of filming in historical landmarks, sophisticated technical equipment, and a casting of prestigious actors" in order to "create a respected and credible image of history through fiction." 704 Considering Televisa's capitalist interests, monopolistic tendencies and close ties to the government, Rodriguez Cadena cautions that its role "in the production of historical series cannot be trusted as a tool of impartial information and generous education." 705

El vuelo del águila comes packaged in six DVDs, and in the span of 26 hours, its plot covers the time period from Díaz's birth in 1830 to his death in 1915. The first disc, entitled "Origins," features the young Díaz as a revolutionary, studious and resourceful family man who is devoted to his mother and sisters. At the outset, women are positioned on the margins of politics; they exist in the space of the kitchen to provide for Porfirio and his brother and not much else. At some point, Doña Petrona, the stereotypical abnegated mother, laments after Porfirio leaves home to enlist in the war that they no longer have a man to protect and defend them. She spends a good deal of the telenovela worrying about her son's fate.

The second disc is entitled "The War" and features several elaborate battle scenes that serve no other purpose than to showcase Díaz's military prowess - there is no

${ }^{704}$ María de los Angeles Rodríguez Cadena, "Contemporary His(tories) of Mexico: Fictional Re-Creation of Collective Past on Television," Film \& History, 34 (2004): 50. ${ }^{705}$ Ibid. 
context as to the causes leading to these battles. What is more interesting here is how indigenous peoples are essentialized and represented as being locked in childish conflicts. For instance, in one scene, as Díaz and his soldiers walk by a couple of men fighting, he explains that they fight because "some are Juchitecos and the others Tehuanos; they hate each other to death," thereby reducing their historical struggle to a primitive interethnic conflict. Moreover, Díaz notes on various occasions, while he is stationed in the Isthmus region of Oaxaca, that "divide and conquer" is the best strategy for "keeping [the indigenous] docile," thus situating them as "pawns in the larger confrontation among the mestizo nation builders of central Mexico."706 In Oaxaca, he also meets and engages in a sexual liaison with the indigenous woman Juana Cata Romero (played by Salma Hayek) (see Appendix A). While Juana at times exhibits a masculine behavior (plays billiards and smokes cigars) and is involved in politics unlike any other female character in the telenovela, her actual economic and political power and role in Mexican history as an informant for the Liberal cause are downplayed and feminized. For example, in the telenovela, she sells colorful ribbons in the market instead of cigarettes as she did in real life. She also practices black magic and most of her dialogue involves expressing her love for Díaz or jealousy over his dalliances with other women. For instance, her last line of dialogue before disappearing from the telenovela is: "Porfirio, remember me and never forget me."

The camera's numerous lingering shots of Juana's body and close ups of her face position her as an object for Díaz to possess; she exists solely in relation to him and has no agency of her own. In one of the more striking scenes, for example, Juana breaks into

${ }^{706}$ Chassen-López, "Distorting the Picture,” 116. 
Díaz's dimly lit hotel room to reproach him for sleeping with other women. After throwing a few punches at him, Díaz forces her down to his bed. He begins to kiss her as she continues to fight him before the scene cuts to the next morning. That this scene can be read as rape does not seem to matter to the telenovela's narrative, which frames Juana as no more than a pawn in Díaz's larger revolutionary struggles. Her body is there to serve Díaz and by extension the nation. The exoticization and sexualization of Juana was not without controversy, however, with the Municipal President and authorities of the city of Tehuantepec launching an official protest against Televisa. In a letter published in the magazine Proceso, the Tehuantepec citizens denounced the depiction of indigenous women as "lewd," as well as "the historical distortions and omissions of our Isthmus heroes."

The fourth disc entitled "Power," which features Díaz as President of Mexico, is interesting for its parallels to the situation in 1994. This part of the telenovela takes place mostly in the presidential palace, with scores of politicians praising Díaz for opening up the economy to foreign investment, creating employment, improving infrastructure and increasing material benefits for the population. The words "progress," "order" and "peace" are, in fact, repeated like a mantra. Various scenes of Díaz attending the opera and theater and throwing lavish parties for his colleagues serve to represent Mexico as a land of prosperity and opportunity. Díaz here is rehabilitated as a hero for the neoliberal era. This part of the telenovela also highlights Díaz's paternalistic "policy of reconciliation" toward the Yaqui people of the northern state of Sonora, which involved granting them land in order to "pacify them," as the Díaz character explains. In one illuminating scene, we see two indigenous leaders and their interpreter meeting with Díaz 
in his office. The latter explains in a patronizing tone that the government has "expropriated land for the benefit of the nation... we have not stolen anything from you. We are working on your behalf." The indigenous people nod and seem to be satisfied with Díaz's statement. The telenovela suggests that listening to and cooperating with the government is the appropriate response to the issue of land rights. In sum, El vuelo del águila can be read as justifying a political regime that sacrifices democracy and other liberties in the name of progress, order and peace.

The (re-) vision of history that Krauze offers in Biography of Power and El vuelo del águila is presented in a neat and linear fashion, and as a continuity of the causes and effects of the Conquest and the Revolution, which works to maintain the status quo. Rodríguez Cadena observes that Televisa's historical telenovelas are "structured as an entity capable of organizing the chaos of historical events and as the providers of this unfailing formula: order $=$ peace $=$ democracy=progress=happiness. ${ }^{, 707}$ These telenovelas function as an ideological tool of social control that can call on its viewers to peacefully follow the system in order to become happy and modern citizens, which in turn delegitimizes social movements like the Zapatistas that proposed more radical political alternatives to neoliberalism.

\section{Representations of a Multicultural Mexico}

In the final section of this paper, I explore the different versions of multiculturalism that the anthropologist Bonfil Batalla and Televisa producers envision in their respective works, México Profundo and María Isabel, at a time when neoliberalism and the question of indigenous rights were both at the forefront of the political agenda in

${ }^{707}$ Rodríguez Cadena, “Contemporary Hi(stories) of Mexico,” 51. 
Mexico. It was in 1996 that the EZLN had agreed to a cease-fire and to sign, in conjunction with the government, the San Andrés Peace Accords concerning indigenous territorial rights, autonomy and intercultural education.

Bonfil Batalla was a member of a group of young professors at the National School of Anthropology in Mexico City who were critical of anthropology's close ties to the state and its homogenizing policies of indigenismo (see previous chapter). México Profundo: Reclaiming a Civilization was first printed in 1987 via then-independent publishing house Editorial Grijalbo (the English version with which I engage in this section was published posthumously in 1996 by the University of Texas Press). This short book, written in an accessible, direct and clear style, is divided into three parts and a total of ten chapters that provide a forceful critique of how the politics of colonialism, mestizaje, indigenismo and capitalism have contributed to exploiting and denying "that which is Indian in Mexico." ${ }^{708}$ In the introduction, Bonfil Batalla explains that the purpose of his book is "to present a panoramic vision of the constant and multiform presence" of Mesoamerican civilization, which survives in many indigenous communities and in other sectors of national society; they together constitute "the México profundo" (deep Mexico). ${ }^{709}$ His central thesis is that the history of Mexico is one of "permanent confrontation" between two opposing civilizations: the dominant and exclusionary Western civilization of the few, or what he calls "the imaginary Mexico," and the Mesoamerican civilization of the many. ${ }^{710} \mathrm{He}$ argues that at present, the "imaginary Mexico" is experiencing a crisis of legitimacy, which has opened up a space for

\footnotetext{
${ }^{708}$ Bonfil Batalla, México Profundo, xv.

${ }^{709}$ Ibid.

${ }^{710}$ Ibid., xvi
} 
reflecting on the country and its trajectory, "for constructing a new national program, which should be framed in a civilizational project that makes explicit our reality instead of hiding it." ${ }^{2111}$ In other words, Bonfil Batalla envisions a civilizational project that embraces the heterogeneous nature of Mexico as a strength rather than a weakness.

The author is especially critical of mestizaje throughout México Profundo. He observes that mestizaje has been a constant ideology since colonialism that has been endorsed as a means of homogenizing and "de-Indianizing" the Mexican nation in order to set it on a path of Western modernization. In chapter seven, entitled "Our (Revolutionized) Modern Times," Bonfil Batalla challenges the work of his intellectual predecessors, such as the anthropology of Gamio and the educational projects of Vasconcelos. He also challenges the cultural nationalism that emerged from the Revolution for having perpetuated the civilizational plan that "did not support the continuity of the 'México profundo,' but, rather, its incorporation - and its negation - in what was going to be a new society. For this reason Mexico had to be mestizo, not plural, and especially not Indian.." ${ }^{, 12}$ Bonfil Batalla targets indigenismo in particular for having promoted the national goal of incorporating indigenous peoples, that is, de-Indianizing them, or "making them lose their cultural and historical uniqueness." ${ }^{, 13}$ In short, he contends that many policies of indigenismo have resulted in ethnocide. In his conclusion to the chapter, Bonfil Batalla condemns the nation-building project of post-revolutionary Mexico for denying its Mesoamerican roots: "[It is] a replacement project that does not propose the development of the existing culture of the majority, but its disappearance...It

${ }^{711}$ Ibid., xix.

${ }^{712}$ Ibid., 112.

${ }^{713}$ Ibid., 116. 
is a project that ideologically affirms mestizaje, but in reality allies itself completely with only one of the components, the Western one... What is left of the Indian cultures of today... is only a folkloric vision and a multiple feeling of uneasiness about what backwardness and poverty might mean." 714 In his view, Mexican nation-builders have been too preoccupied with transforming the country into that which it is not (Western) to the extent that the (Mesoamerican) culture of the majority has been denigrated as a shameful condition to overcome.

The mass media is cited as a prime example of this alliance with a Western model of development at the expense of others. Bonfil Batalla notes that for the media, "Mesoamerican civilization does not exist.." ${ }^{, 15} \mathrm{He}$ continues: "[The media] suggest a way of understanding and living a culture that is not within the reach of everyone...but to which all should aspire. [They], above all, consolidate a vision of a Mexico that does not exist." ${ }^{, 716}$ In the Mexico of Televisa, for example, brown faces are suppressed in favor of white actors, the lifestyle of the rich predominates, and upward mobility is available to the poor through love and marriage. On the few occasions that indigenous culture has been included, as in the case of María Isabel, its representation is merely folkloric.

A further example that negates Mesoamerican civilization, according to Bonfil Batalla, is museums. In the third chapter entitled "De-Indianizing that which is Indian," he provides a strong critique of the National Museum of Anthropology that is located in the upscale Chapultepec area of Mexico City. He notes that the museum's architectural design in itself "reflects an ideology of exaltation of the precolonial past. Simultaneously

${ }^{714}$ Ibid., 128.

${ }^{715}$ Ibid., 124.

${ }^{716}$ Ibid. 
and in a contradictory fashion, it expresses a rupture with the present."717 The spatial layout of the museum separates pre-Columbian civilizations, with the Aztecs occupying the largest room on the ground floor, from contemporary indigenous groups. The ethnographic exhibits regarding the indigenous of today are located on the top floors, which many visitors skip, as Bonfil Batalla points out, "because of fatigue or lack of interest, both factors directly related to the layout of the museum space."718 The National Museum of Anthropology is designed so as to exalt ancient indigenous civilizations as the seed and soul of Mexico, while at the same time "the contemporary Indian occupies a segregated space, disconnected from the glorious past as well as from the present, which does not belong to him: an expendable space." ${ }^{719}$ The spatial distance between past and present underscores the fact that contemporary indigenous peoples continue to be viewed as an uncomfortable presence with no contributions to make to the modern Mexican nation.

Bonfil Batalla debunks the notion that there exists in Mexico a unified national culture because it is a country comprised of various heterogeneous groups of people who have different and sometimes contradictory ways of life. In the final chapter, entitled "Civilization and Alternatives," he proposes that the civilizational plan the country should follow be organized on the basis of cultural pluralism rather than mestizaje, which has historically been deployed to dominate and deny Mesoamerican civilization. He explains: "Pluralism would not be understood as an obstacle to be overcome but, rather, as the content itself of the project, that which makes it legitimate and viable. Cultural

717 Ibid., 54.

718 Ibid.

719 Ibid., 55. 
diversity would not be simply a reality recognized as the point of departure, but, instead, a central goal of the project. The attempt would be to promote development of a multicultural nation without its ceasing to be exactly that. ${ }^{" 720}$ Bonfil Batalla argues that in order to construct this ethical multicultural nation that he envisions, there must first be a decentralization of power, destruction of colonial ideologies, recognition of indigenous collective rights, and guarantee of indigenous democratic representation and participation in national life. He concludes by stating that if Mexicans let the "deep Mexico" speak and learn to respect and "affirm our differences, to ourselves and to outsiders, we [can] radically deny the would-be hegemony of the West." ${ }^{, 721}$ For the author, the politics of multiculturalism are a viable alternative to the Western and capitalist model of development that has caused much pain and destruction in Mexico.

México profundo reads like a necessary and critical intervention in Mexican intellectual thought that recognizes mestizaje as an oppressive and racist ideology. The book also anticipates the rise of multiculturalism and indigenous mobilization of the 1990s. However, the image of a deep versus imaginary Mexico, as Lomnitz observes, reproduces "the modernist trope of tradition versus modernity" 722 that feeds into the type of populist multiculturalism that emerged in Mexico. The cover images of traditionallyclothed indigenous women (in the Spanish version) and of an aging indigenous face (in the English version) in themselves highlight that Bonfil Batalla conceived "the deep Mexico" as being comprised of traditional, rural and poor indigenous peasants. Moreover, the language of cultural diversity and plurality was easily coopted by the state,

${ }^{720}$ Ibid., 166.

${ }^{721}$ Ibid., 176.

${ }^{722}$ Lomnitz, Deep Mexico, Silent Mexico, 264. 
which symbolically acknowledged the multicultural nature of the nation, but failed to reform its political and social structures. The reformed Mexican Constitution, for example, stipulated: "Mexico is a multicultural nation based originally upon its indigenous peoples. The law will protect and promote the development of their languages, cultures, practices, customs, resources and specific forms of social organization, and will guarantee its members effective access to state jurisdiction." This text was criticized by indigenous organizations for being "lukewarm and ambiguous.",723 A final point to make here is that the emphasis on cultural differences allows the state to ignore the issue of racism. Race studies scholar Juliet Hooker remarks that "once cultural diversity is recognized," states might conveniently neglect to address "the social and economic aspects of racial injustice." 724

The telenovela for discussion in this section is María Isabel, broadcast from Monday to Friday on prime time from 1997 to 1998. The story of María Isabel first appeared in Mexico on the comic strip Lágrimas, risas y amor (Tears, Laughter and Love), written by Yolanda Vargas Dulché; it was adapted as a telenovela in 1966 and as a film in 1967, with a sequel released in 1968. The influence of Vargas Dulché in Mexico cannot be overstated. She was a pioneer in the comic strip world, having created the beloved Memín Pinguín, which is said to have contributed to the education of the popular classes in the country. The aforementioned Lágrimas, risas y amor set a record in circulation, printing over four million copies each month. Many of its romantic stories, such as "Yesenia," "Rubí," "Alondra," "El pecado de Oyuki” and "María Isabel," were adapted as telenovelas. Overall, Vargas Dulché sold over 25 million monthly copies,

723 De la Peña, “A New Mexican Nationalism?” 287.

${ }^{724}$ Hooker, "Indigenous Inclusion/Black Exclusion,” 24. 
making her one of the most widely read and important Spanish-language authors of the twentieth-century. ${ }^{725}$ My interest here is to explore the significance of having adapted María Isabel in the 90s. How does Televisa contribute to the conversation about multiculturalism with its representation of Huichol indigenous peoples and culture?

María Isabel is an archetypal "pink telenovela" that emphasizes romantic escapism and a Manichean vision of the world, where good always triumphs and love conquers all. Three prominent factors that characterize Televisa's storylines, which Fernández and Paxman summarize as "sexual conservatism, social Darwinism and racial elitism," ${ }^{, 726}$ all make an appearance on María Isabel. Sexual conservatism in telenovelas has been the most obvious. Female protagonists tend to be virginal, demure, sentimental, devout to their man and Catholic religion, and identify with the Virgin of Guadalupe, which explains why many of them are named María. In contrast, "las malas," or the female villains, are cold, domineering and sexually aggressive both in behavior and appearance. Their objective is to steal the heroine's man and make her suffer in all sorts of ways. The villains' transgressions of Catholic family values are ultimately punished; they either die a violent death or go mad or are condemned to solitude in prison. The male hero for his part is allowed to engage in various sexual dalliances until he is redeemed by the pure love of the heroine. This machista double standard already present in Mexican society has been reproduced ad nauseam in Televisa's programming.

\footnotetext{
${ }^{725}$ Robert McKee Irwin, "El recurso literario latinoamericano en su contexto globalizado," Cuadernos de literatura, 17 (2013): 77. Arturo Cruz Bárcenas, "Yolanda Vargas Dulché, una de las mujeres más leídas en México," La Jornada, November 22, 2012, accessed January 5, 2018, http://www.jornada.unam.mx/2012/11/22/espectaculos/a08n1esp.

${ }^{726}$ Fernández and Paxman, El tigre, 81.
} 
Social Darwinism has been most evident in Azcárraga's paternalistic attitude toward his audience. He believed that his role was to provide to his largely working-class viewers moments of happiness and escapism from their miserable reality. In his biography of Azcárraga, Saragoza notes that Azcárraga wanted to direct "his viewers to accept their world, to find redemption in patience and sacrifice. His viewers were thus idealized, their daily struggles romanticized and their impoverished hopes were dignified." 727 In María Isabel, for instance, the word "honrada" (honest, honorable) is used multiple times to describe and in turn idealize the titular character. For example, María Isabel refers to herself on separate occasions as, "poor but honest;" "I'm an Indian, but I know how to work and I'm very honest;" "I'm an Indian, but I'm good and honest;" and "I'm happy because I'm honest" (emphasis mine). María Isabel is thus framed as the most moral of all characters that is capable of accepting her situation with dignity, honesty and pride. As American Studies scholar Adriana Estill observes, telenovelas invest the majority of viewers "with moral and social power, in order to compensate them for not having financial power. Nation-ness, in Televisa's view, inheres in common decency, respect and honor." 728 It is also interesting to note how the words "poor" and "Indian" are qualified with positive adjectives, which seems to suggest that María Isabel is an exceptional indigenous woman who is different than the rest of her community $-\mathrm{a}$ community that is presumably not honest, not good and not hardworking. Finally, racial elitism has been especially evident in the casting of white and light-skinned actors as

727 Ibid., 82.

${ }^{728}$ Estill, "Closing the Telenovela's Borders," 82. 
protagonists, or in the case of María Isabel, in the near absence of indigenous peoples, ${ }^{729}$ despite borrowing from Huichol culture, which reinforces the admiration of AngloEuropean standards of beauty. The characters that experience upward mobility can do so because they exhibit white skin and phenotypes in the first place, and as such, it is their natural right to ascend to the highest social strata.

María Isabel's eponymous character is a beautiful and virtuous indigenous woman (played by Adela Noriega) who resides with her grandparents in a sleepy and picturesque village untouched by modernity (the only electronic appliance they own is a television) in the state of Nayarit. The indigenous element here is exalted and portrayed with great pride. For example, the promotional trailer ${ }^{730}$ boasts of the fact that the telenovela was shot in the "natural scenery of the Mexican campo," and it describes María Isabel as a "humble" and "innocent" young campesina (peasant) who will "confront the dangers and temptations of the big city with courage and the dignity and pride of her race." Note here the conflation of race and class - to be indigenous and a poor peasant are one and the same. The opening credits depict María Isabel with long braids, colorful huipils (embroidered tunics), barefoot and surrounded by extravagant sunflowers and lilies (see Appendix B) - not unlike the indigenous women Diego Rivera and other muralists painted during the revolutionary zeal of the 1920s. The beginning of the telenovela establishes María Isabel as a hard-working, loyal and abnegated woman

\footnotetext{
${ }^{729}$ According to film studies scholar James Snead, the omission of indigenous, brown and black bodies is one of the most widespread tactics of racial stereotyping. The absence of minorities from "locations of autonomy and importance" creates the idea that they "belong in positions of obscurity or dependence" ("Spectatorship and Capture in "King Kong:' The Guilty Look," in Representing Blackness: Issues in Film and Video, ed. Valerie Smith [New Brunswick, NJ: Rutgers University Press, 1997], 29).

${ }^{730}$ See https://www.youtube.com/watch?v=4a4DaVu4KAc .
} 
who is fiercely devoted to her white and upper-class friend Graciela. In fact, the very first words she says to Graciela when they meet as children are, "Soy María Isabel, pa' servirle a usted" ("I am María Isabel, at your service"). This very act of exalting the indigenous, according to media studies scholar Charles Ramírez Berg, serves as "an instrument of marginalization" because it sets indigenous peoples apart. "Making Indians exotic makes them peculiar: strangers in their own land,"731 which in turn serves to reinforce the normativeness of the dominant culture.

For all its alleged pride in indigenous culture, María Isabel displays a plethora of racial, ethnic and class stereotypes. For example, when María Isabel migrates to the capital city to find a job as a domestic worker, her ignorance in how technology works, her mispronunciation of Spanish words and thick accent are all exaggerated to provide comedic relief. One particular striking scene that features some physical comedy sees María Isabel arguing with her two flamboyant employers. The latter accuse the former of being a thief and slap her so that "she learns to respect us." Visibly insulted, María Isabel says, "You will know this Huichola Indian," and proceeds to fight them. She bites her employers and tears out their wigs and clothes, as they scream for help and call her an animal. María Isabel retorts, "Now you know what an angry Huichola Indian is like," and walks out of their house with her head held high. This scene that feels more like a sit-com than a melodrama is intended to defend María Isabel's honor and moral virtue - she may be an "Indian," but she is not a thief. However, the fact that María Isabel responds to her aggressors with bites and punches reinforces the notion that indigenous peoples are

${ }^{731}$ Ramírez Berg, Cinema of Solitude, 148. 
irascible and animalistic. ${ }^{732}$ Moreover, cultural critic Carlos Monsiváis observes that the faithful reproduction in film and television of "the speech of the hardly Hispanicized becomes a way of mocking the subjects so described, turning their 'sympathetic' qualities into submissive stupidity. Repeated ad nauseam, [their] speech becomes a joke." ${ }^{, 733}$ Sure enough, María Isabel's speech (her constant mispronunciation of "nadie" as "naiden" and of "fuera" as "juera," for example) is meant to be humorous and to elicit gentle smiles from the educated middle-classes. Furthermore, the epithet of "Indita" (little Indian) is directed at her in numerous occasions to insult or patronize her, which positions her as a subaltern. According to the telenovela, to be indigenous is to be an inadequate and undesirable body in the urban environment.

Because María Isabel is already a light-skinned beauty, viewers know that she will capture the attention and love of her patrón (boss) Ricardo (Fernando Carrillo). Ricardo acts as the benefactor who motivates María Isabel to become educated, which in turn propels her into the modern, white world. As with Valentín Pimstein's telenovelas mentioned in the previous chapter, education in this telenovela is not so much about acquiring literacy and working skills, but about learning to embody the qualities of whiteness. Toward the end of the telenovela, for example, María Isabel learns to speak what is deemed proper Spanish and with the right accent; she learns how to speak English, to play the piano and to pick the right type of wine; she wears straight hair and elegant clothing and jewelry; and she vacations in Europe. In short, she sheds the markers

\footnotetext{
${ }^{732}$ Cinema studies scholars Ella Shohat and Robert Stam note that in colonialist discourse, tropes or metaphors of indigenous peoples as animalistic, exotic and primitive serve to establish Anglo-European superiority (Unthinking Eurocentrism, 137). The usage of these "tropes of empire" effectively constructs an "Other" that must be domesticated before she/he can be granted access to full citizenship.

${ }^{733}$ Monsiváis, Mexican Postcards, 90.
} 
of her indigenous roots in order to become a respectable member of the upper class, or to become "worthy of [Ricardo] and to please him," as María Isabel explains to her teachers. According to social anthropologists Séverine Durín and Natalia Vázquez, this telenovela's narrative works to "reassure the public" because it endorses the "idea that indigenous integration is possible through mestizaje and paternalism." ${ }^{, 734}$ However, not all indigenous people in the telenovela are assimilated into the dominant culture. María Isabel's grandparents, for example, who are brown and exhibit more pronounced indigenous features, are depicted as traditional, community-bound, isolated and with no aspiration to leave behind their poor village (see Appendix C). As Chassen-López observes, these "controlling images" are designed to make poverty appear to be a natural, normal and inevitable part of the everyday life of brown and indigenous peoples, thereby enabling dominant groups to blame them for their situation. ${ }^{735}$

Stereotypical representations of indigenous peoples function as a way of naturalizing their exclusion from access to resources and opportunities. Martínez Novo notes that in Mexico, these representations can range from the "openly hostile" to a form of "paternalistic love," reflecting the nation's long-standing ambivalence toward indigenous peoples. ${ }^{736}$ Paternalism is particularly evident in one of the telenovela's minor subplots that features one of María Isabel's mestizo, middle-class friends traveling to her former village to research indigenous music. He explains in a patronizing tone to María's grandparents (as if they need reminding) that "autochthonous music must be recognized"

\footnotetext{
${ }^{734}$ Séverine Durín and Natalia Vázquez, "Heroínas-sirvientas: Análisis de las representaciones de trabajadoras domésticas en telenovelas mexicanas," Trayectorias, 15 (2013): 31.

735 Chassen-López, "Distorting the Picture," 108.

${ }^{736}$ Martínez Novo, Who Defines Indigenous? 97.
} 
and that he will make it his mission "to rescue our music." The telenovela essentializes indigenous peoples as ignorant and primitive beings, whose culture must be protected and defended by the civilized mestizo man. Moreover, the focus on music, while important, is the kind of folkloric project that the Mexican state can readily embrace under neoliberal governance.

María Isabel's indigenous peoples are for the most part content and passive in their situation; they embody the previously discussed category of the "permitted Indian." Toward the end of the telenovela, however, we get a brief glimpse of the "un-permitted Indian" in one particular striking scene, in which María Isabel's entire village arms itself to fight against and punish the rich landowner who poisoned their water. María Isabel, worried about her peoples" "explosive" temper, sends her white husband to reason with and convince them that the most sensible idea is to let the police take care of justice. The telenovela here not only equates indigenousness with violence, but it compounds the message that incitement to political conflict is not to be tolerated in a neoliberal Mexico. Moreover, the logics of neoliberalism conveniently "responsibilize" indigenous peoples for structural limitations and inequalities. In the telenovela, the inability to overcome a life of poverty is reduced to the personal failings of indigenous peoples. On the other hand, María Isabel is the exceptional indigenous woman who attains progress and modernity because she works hard and aspires for a better life. The figure of María Isabel is mean to demonstrate that integration into the nation is a matter of personal will.

On the one hand, Bonfil Batalla argued that democratic changes to political and social structures needed to be implemented in order to create an ethical multicultural Mexican nation. On the other, Televisa supported and legitimized the state with its widely 
distributed images of folkloric indigenous peoples, whose culture ought to be respected and celebrated as long as they stay in their place, removed from the urban milieu.

Furthermore, Televisa posited domestic work as the means by which to integrate those indigenous peoples who reside in cities. The remake of María Isabel in the 90s worked in tandem with the Mexican state and its neoliberal policies to limit indigenous representation and to domesticate the more radical movements that posed a threat to their hegemony.

\section{Conclusion}

Mexico in the 90s erupted into a series of debates about what it meant to be Mexican in the age of NAFTA, neoliberalism and indigenous mobilization. The events in 1992 and 1994 further challenged the viability of mestizaje as the basis of Mexican nationalism, paving the way for the rise of multicultural rhetoric. The year 1992 marked the quincentenary anniversary of Columbus' arrival to the Americas. Large-scale and indigenous-led protests were held across the American continent to challenge the institutional romanticization of Columbus and the representation of his arrival as an "encounter." Race studies scholar Juliet Hooker observes that the use of the term “encounter," with all its peaceful connotations, was especially problematic because it assumes that peoples voluntary came together and on equal footing; it thus serves to erase "the violence and conflict inherent" in colonialism. ${ }^{737}$ These protests were also held to shed light on contemporary social injustices. ${ }^{738}$ In Mexico City, for example, thousands

\footnotetext{
${ }^{737}$ Juliet Hooker, "Hybrid Subjectivities, Latin American Mestizaje, and Latino Political Thought on Race," Politics, Groups and, Identities, (2014): 9-10.

738 Jeremy Smith, "Outside and Against the Quincentenary: Modern Indigenous Representations at the Time of the Columbus Celebrations," Atlantic Studies, 6 (2009): 69.
} 
gathered at the central plaza to demand President Salinas to make reforms to public services, bilingual education and land. ${ }^{739}$ These demands for social justice, democracy and autonomy became the basis of the "500 years of resistance" movement, which was comprised of a transnational network of indigenous organizations and sponsored quincentenary protests across Latin America, including Argentina, Bolivia, Costa Rica, Guatemala, Ecuador, Mexico and Paraguay. ${ }^{740}$ This movement set the precedent for the emergence of the neo-Zapatistas in 1994.

In this chapter, I traced the movement of neoliberalism and multiculturalism to explore how these were expressed across national culture, ranging from the works of the more prominent Mexican intellectuals to the mass media. I stressed the central role of Televisa in sponsoring intellectuals and constructing a vision of a modern Mexico. Fernández and Paxman point out that as a modernist, Azcárraga helped shape a Mexico more akin to the US and in a way prepared it for entry into NAFTA. ${ }^{741}$ Moreover, Chassen-López remarks that it is "imperative to analyze [telenovelas] because they mediate in the construction of cultural identity." ${ }^{.742}$ It is interesting to note how new media and independent networks, such as Canal Once (discussed in the next chapter), have begun creating original programming that has the potential to challenge the hegemony of Televisa and to open up a space for a more flexible definition and representation of Mexican identities.

\footnotetext{
${ }^{739}$ Timothy Kubal, Cultural Movements and Collective Memory: Christopher Columbus and the Rewriting of the National Origin Myth (New York: Palgrave Macmillan, 2008), 93. ${ }^{740}$ Ibid.

${ }^{741}$ Fernández and Paxman, El tigre, 410.

${ }^{742}$ Chassen-López, "Distorting the Picture," 122.
} 
Appendix A



Retrieved from: https://www.youtube.com/watch?v=likcXE8o_Zw (accessed May 30, 2017). 
Appendix B

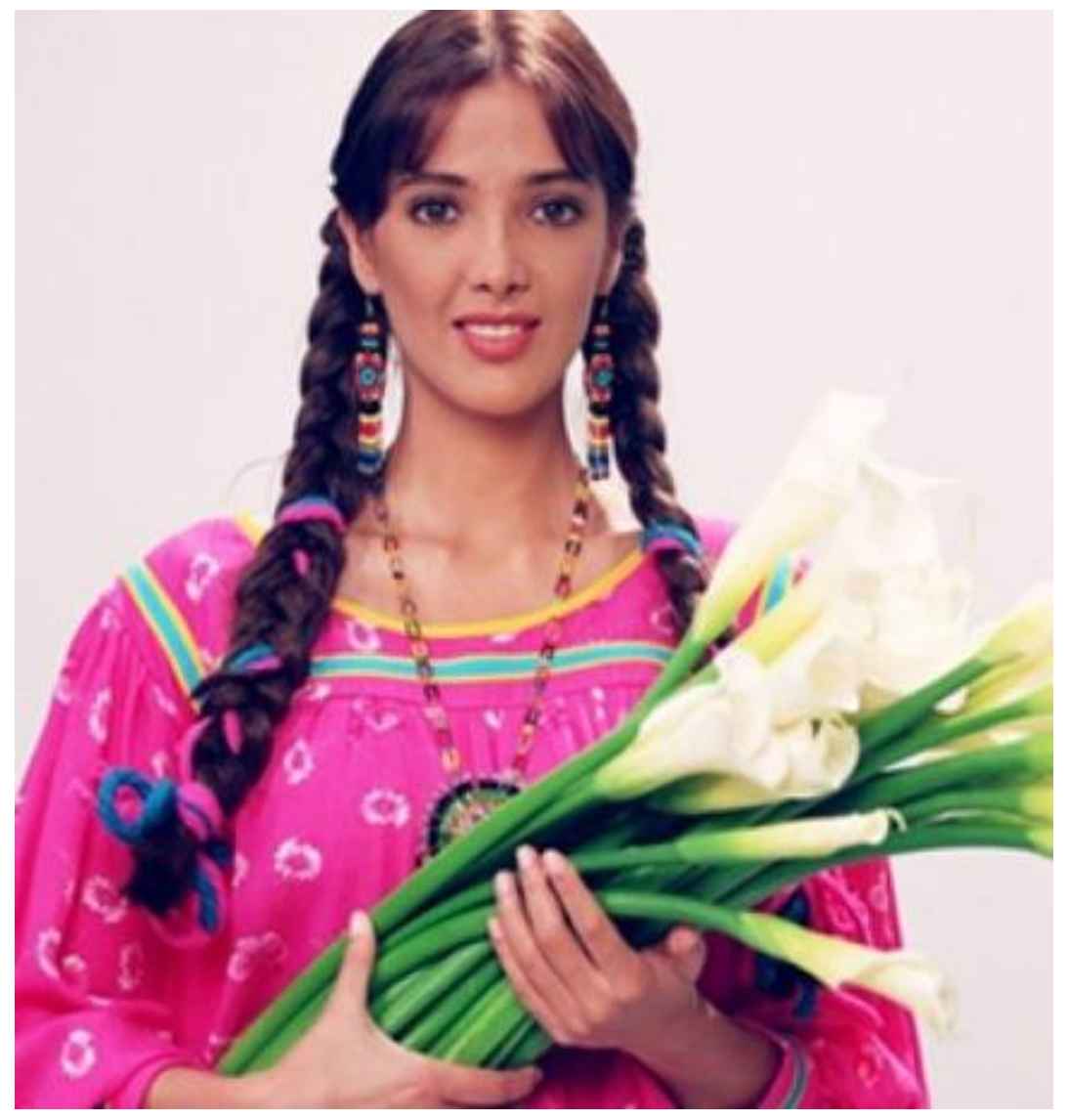

Retrieved from: http://carlosochoaysusnovelas.blogspot.com/2015/09/si-tu-supierasmaria-isabel-carlos.html (accessed May 30, 2017). 
Appendix C

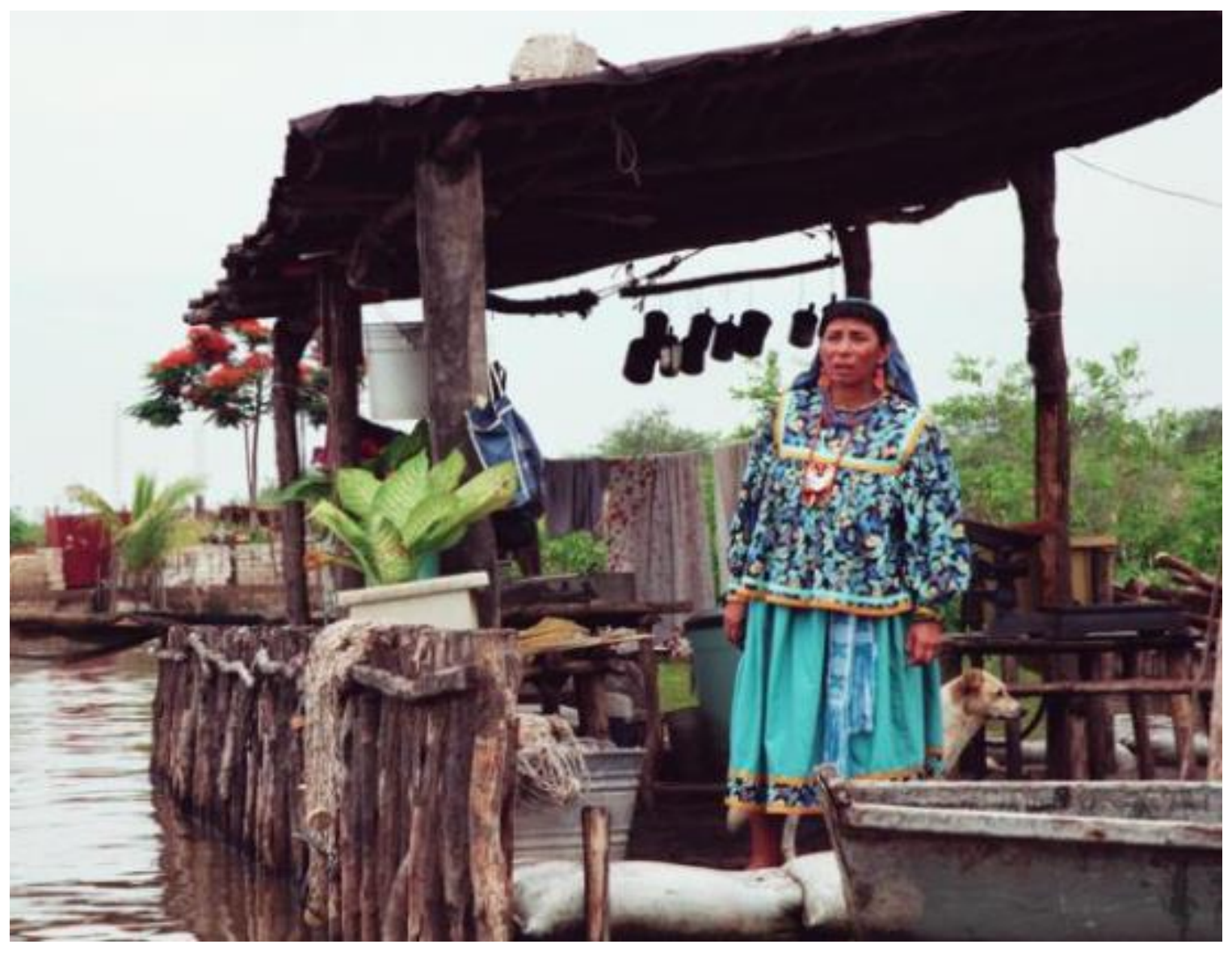

Retrieved from: http://carlosochoaysusnovelas.blogspot.com/2015/09/si-tu-supierasmaria-isabel-carlos.html (accessed May 30, 2017). 


\section{Chapter Eight}

\section{Chronicles of Race and Class on Late-Night Television}

Mezclarnos siempre trajo consecuencias (Mixing always had its consequences), reads the promotional poster of the Mexican television series Crónica de castas (Chronicles of Caste), which premiered in April 2014 on the public network Canal Once. The same poster (see Appendix A) features the portraits of the two protagonists: the brown, mustachioed Raúl (Harold Torres), whose forehead is marked in red as mestizo, and the blond and fair-skinned Lucía (Naian González Norvind), marked as criolla. The trailer $^{743}$ for its part begins with a university professor explaining to his students the racist logic of the colonial caste system, "here it begins a stratification related to skin color," as we see Lucía escaping her bourgeois life and meeting Raúl, a taxi driver from the poor neighborhood of Tepito. We also get a glimpse of how the diverse worlds of Mexico City interact and collide with one another.

In this chapter, I explore how Crónica de castas depicts the consequences of mixture over the course of nine episodes and challenges the mythology of mestizaje, which insists all Mexican citizens are of mixed blood and of equal status. How does the depiction of everyday experiences of racism and classism in the series serve to expose mestizaje as a nationalist fiction disconnected from the Mexican reality? Screenwriter Jimena Gallardo and director Daniel Giménez Cacho both stated explicitly in interviews that they wanted to represent the historical continuities of racism and discrimination in Mexican society, which makes Crónica de castas a rare feat in Mexican television,

${ }^{743}$ See https://www.youtube.com/watch?v=kaNuAcecU-4 
considering that fantasies of whiteness, upward mobility and modernization continue to be the dominant features of telenovelas and advertisements.

In the first section, I provide a historical account of the term "casta." I examine how the sistema de castas (caste system) was intimately linked to the regulation of urban spaces and how it materialized in the paintings of the colonial period in order to contextualize the television show and shed light on its representation of contemporary forms of exclusion and discrimination. In the next section, I provide a detailed analysis of three episodes, discussing various issues, such as the conflation of race and culture, language and its relation to power, religion, music and the significance of having shot the series in the Mexico City neighborhood of Tepito, marginalized and vilified as a crimeridden space. I conclude with a brief reflection on the series' potential to disturb what is assumed to be the norm.

\section{Castas in Colonial Mexico}

In the sixteenth century, colonial society in Mexico was conceived in terms of division and separation. Mexico was divided into the república de españoles (Spanish republic), under the direct control of the Spanish Crown, and the república de indios (indigenous republic), governed at a distance through the native nobility that retained a degree of local authority. ${ }^{744}$ Art historian Magali Carrera notes that the republics' conceptual and physical separation took shape as the capital city was built. For example, Spaniards lived in a rectangular area in the city center called the traza, where streets were orderly and municipal services were readily available. Surrounding the traza was the indigenous section of the city, with limited services and dilapidated housing and

\footnotetext{
${ }^{744}$ Douglas Cope, The Limits of Racial Domination: Plebeian Society in Colonial Mexico City, 1660-1720 (Madison, WI: Wisconsin University Press, 1994).
} 
streets. ${ }^{745}$ Such spatial boundaries, however, were undermined by the function and placement of the Plaza Mayor near the traza, which housed major institutions, such as the cathedral, the viceregal palace, the city council and the marketplace. ${ }^{746}$ The marketplace became the center of economic activity, where people from the city and its environs came together on a daily basis to buy, sell and exchange goods, making the neat Spanish-indigenous division unsustainable.

According to Carrera, Bourbon reformers argued that the capital city needed to be further divided into cuarteles, or manageable units, with an administrator for each in order to contain and organize the growing population. These administrators had to maintain detailed information on all the units' inhabitants, such as their family name, marriage status and job title. ${ }^{747}$ In addition to the cuartel system, the government issued various decrees in an attempt to discipline the population and their spaces, bodies and activities. For example, the 1776-1778 Pragmatic Sanction on Marriages allowed parents and civil servants to prohibit marriages that were between "social unequals," or among lower castas, in order to curtail the proliferation of mixed-race peoples. ${ }^{748}$ Sumptuary laws for their part determined what colonial bodies could and could not wear, prohibiting the use of expensive jewelry and fabrics. ${ }^{749}$ At the same time, cleanliness, hygiene and nakedness were seen as problems to address among the plebeians. Certain leisure activities like carnivals were also prohibited. Carrera observes that the fact that many of

\footnotetext{
${ }^{745}$ Magali Carrera, Imagining Identity in New Spain: Race, Lineage, and the Colonial Body in Portraiture and Casta Paintings (Austin, TX: University of Texas Press, 2003), 34.

746 Ibid., 35.

${ }^{747}$ Ibid., 111.

748 Ibid., 118.

${ }^{749}$ Ibid., 119.
} 
these decrees and mandates had to be reiterated points to the failure to fully control colonial bodies.

The sistema de castas reached institutional form in the seventeenth century and persisted until the eighteenth century as an attempt of Bourbon authorities to classify, regulate and manage the different and numerous mixed-race peoples that constituted Mexican society. Art historian Ilona Katzew and other scholars point out that the sistema de castas, which ranked people according to their alleged percentage of Spanish, indigenous or African heritage (or blood), which then determined their rights, obligations and place in society, was invented in order for the elite criollos (Spaniards born in the Americas) to avoid being associated with "tainted" blood, ${ }^{750}$ and because they needed a mechanism of social control that could secure their positions of power and privilege. ${ }^{751}$

The sistema de castas functioned in part through the use of labels that collapsed national character and race into one, such as Spaniard, mestizo and mulatto, in order to categorize and rank individuals. The term mestizo, for example, was used to describe the

\footnotetext{
${ }^{750}$ The hierarchical order in Spain was based on the subordination of state to church and on the ideology of limpieza de sangre (purity of blood), which denoted the absence of Jewish or Muslim blood. Anthropologist Claudio Lomnitz comments that purity of blood was tied to honor in that "it reflected the depth of a lineage's loyalty to Christianity" and thence, to an individual's moral attributes, such as trustworthiness and decency (Exits from the Labyrinth, 264). In the colonies, the creole elite translated the principle of "purity of blood" from religious belief to a de facto social stratification based on skin color, phenotype and class status, which placed creoles at the top of the racial pyramid and black people at the bottom (Mignolo, The Idea of Latin America, 74).

${ }^{751}$ Ilona Katzew, Casta Painting: Images of Race in Eighteenth-Century Mexico (New Haven, CT: Yale University Press, 2004). José F. Buscaglia-Salgado, Undoing Empire: Race and Nation in the Mulatto Caribbean (Minneapolis, MN: University of Minnesota Press, 2003). Magali Carrera, "Locating Race in Late Colonial Mexico," Art Journal, 57 (1998): 36-45. Susan Kellogg, "Depicting Mestizaje: Gendered Images of Ethnorace in Colonial Mexican Texts," Journal of Women's History, 12 (2000): 69-92. Robert C. Schwaller, "Mulata, hija de negro [e] india": Afro-Indigenous Mulatos in Early Colonial Mexico,” Journal of Social History, 44 (2011): 889-914.
} 
offspring of Spaniards and indigenous peoples, while mulatto referred to the mixture of Spaniards and Africans. In regards to mulatto, the Spanish jurist Juan de Solórzano y Pereira argued that this term was appropriate because this racial combination "was deemed uglier and stranger, and to make the point of comparing it to the nature of the mule." ${ }^{752}$ The appellations that emerged at the time to describe the mixture of Africans and indigenous peoples were varied, but were mostly derived from a zoological vocabulary, such as lobo (wolf), coyote, zambo (knee-knocked), barcino (an animal with a brown or reddish white coat and black spots) and albarazado (from the Arabic albaras, or white leprosy, suggesting that mixture that did not involve a Spanish body could result in offspring prone to illness and degeneracy). At its most extreme, the sistema de castas included more than 40 racial categories, though most of these did not have any practical significance. ${ }^{753}$ The most recurrent racial terms that appeared in official documents, such as marriage certificates, birth certificates, census records and Inquisition cases, were limited to Spaniard, castizo (the mixture of Spaniards and mestizos), morisco (the offspring of Spaniards and mulattos - a term derived from the Spanish word for Moors), mestizo, mulatto, Indian and black. While in theory, the sistema de castas was meant to provide a sense of order to an increasingly complex society, in practice, this system became "an entangled naming game in which few terms meant one thing or were applied in any consistent manner.",754

The hierarchy of the sistema not only relied on somatic traits to determine an individual's racial identity, but also on the concept of calidad (quality, or an individual's

${ }^{752}$ Katzew, Casta Painting, 44.

${ }^{753}$ Cope, The Limits of Racial Domination, 24.

${ }^{754}$ Katzew, Casta Painting, 44. 
overall reputation determined by economic, social, cultural and racial factors). ${ }^{755}$ Carrera explains that the qualities and attributes perceived to be inherent to the castas were illegitimacy, impure blood, criminality, drunkenness, idleness, poverty, plebeian status and manual labor. In contrast, wealth, nobility, landholder status, purity of blood and legitimacy were all associated with being Spanish. ${ }^{756}$ The casta taxonomy overlapped with other models of classification that further placed an emphasis on cultural and economic divisions: gente de razón (people of reason) versus indigenous peoples; gente decente (decent people) versus the plebe (plebeians), also known as gente vulgar and populachos, all terms connoting degradation and degeneracy; and tributaries (indigenous peoples, Africans and mulattos) versus non-tributaries. ${ }^{757}$ However, the high rate of intermarriage among castas and their ability to enter previously designated Spanish trades, such as retailing and artisanry, blurred these Spanish-casta divisions, causing deep anxiety among the colonial elite. Carrera notes that the casta paintings produced in the late 1750 s and 1760 s emerged as a form of "social engineering that was being carefully put into place by Bourbon reformers as they attempted to construct, control, and maintain colonial bodies and the spaces they occupied." ${ }^{, 758}$

Casta paintings recorded the process of mestizaje in a progression of images, usually a series of sixteen scenes, depicting a man (of higher status), woman (of lower status) and one or two children, each designated with a racial label. The paintings began with scenes of individuals of a "purer" racial identity and a higher socioeconomic status,

${ }^{755}$ Nasheli Jiménez del Val, "Pinturas de Casta: Mexican Caste Paintings, a Foucauldian Reading," New Readings, 10(2009): 9.

${ }^{756}$ Carrera, Imagining Identity in New Spain, 37.

${ }^{757}$ Ibid., 42.

758 Ibid., 43. 
reflected in their light skin color, opulent clothing and domestic space, and moved on to individuals who were more mixed and were thus depicted as darker, poorer, in tattered clothing and in the space of the kitchen or the market, often working (selling vegetables, making cigarettes and so on). ${ }^{759}$ Caribbean studies scholar José Buscaglia-Salgado points out that some of these paintings further identified the castas by adding to the images a brief text describing the "moral" character of the type. ${ }^{760}$ The mestizo, for example, was said to be "naturally humble, peaceful and simple."761 Other types were thought to be prone to gambling and stealing, to being lazy or restless, or to being good and benign, "according to their relationship to and distance from the European Ideal."762 In other words, the casta paintings served to establish the white Spanish as a model of ideal humanity against which all other castas were measured as deviant, thereby allowing the former to gain authority. It was also not uncommon to end these paintings with images of native indigenous peoples who were considered to have pure blood, unlike the castas. These natives were portrayed as semi-naked and in the wilderness so as to reinforce the belief that they were separate from and thus uncontaminated by the urban environment.

Three important themes recurred in the casta paintings. First, as historian Susan Kellogg observes, "the paintings idealized and domesticated interracial relationships...depicting tranquil scenes of nuclear families." ${ }^{, 763}$ This was an effective

\footnotetext{
${ }^{759}$ Katzew comments that because "somatic subtleties could never be adequately translated in the media of paint...clothing and other accouterments often appear[ed] as ancillary elements needed to reinforce racial and class distinctions" (Casta Painting, 204). Moreover, this divide between domestic and public spaces served to fix the castas "spatially in their particular environments" (Jiménez, "Pinturas de Castas", 10).

${ }^{760}$ Buscaglia-Salgado, Undoing Empire, 173.

761 Ibid.

762 Ibid., 174.

${ }^{763}$ Kellogg, "Depicting Mestizaje," 74.
} 
method of obscuring the violence, conflicts, inequalities and poverty of everyday life. Second, the images were "gendered through their forms, poses, clothing, and in the patterns of interethnoracial couplings." ${ }^{.764}$ In other words, the fact that higher status men were coupled with lower status women served to naturalize both identity categories (race and gender), "attributing power to men and inferiority to women and reinforcing idealized familial and societal themes." ${ }^{765}$ When images of familial discord were represented, these were invariably gendered and racialized. Kellogg points out, for example, how one painting showed a mulatta trying to slap her partner and in another, a black woman attacked her Spanish master with a mallet, which underscores that blackness was perceived to be a violent threat. Native and mestiza women, on the other hand, were portrayed as submissive and passive. These paintings relied on racial and gender identities to make the Spanish-casta hierarchy seem like a natural aspect of everyday life.

The third and most important theme of these paintings is that the interracial couples depicted always produced a child of a different category than each parent. Katzew argues that this had a didactic function because it could teach viewers to follow the "right" pattern of mixing in order to reach the desired Spanish, or white, status that was perceived to grant access to privilege, power and wealth. For example, the mixture of Spaniard and indigenous bore the "promise of a return to a pure (that is, Spanish) racial pole" in three generations: ${ }^{766}$ Spaniard and indigenous produced mestizo; Spaniard and mestizo produced castizo; and Spaniard and castizo produced Spaniard. The Spanish

\footnotetext{
${ }^{764}$ Ibid., 75.

765 Ibid., 76.

${ }^{766}$ Katzew, Casta Painting, 202.
} 
category was thus framed as an aspirational ideal. In contrast, the mixture of Spaniard and African could never be purified. The casta paintings did depict the gradual whitening of the African-Spanish progeny, resulting in the albino/a category (usually epitomized in the figure of a blond and blue-eyed woman) after three generations. However, the fact that the mixture of albina and Spaniard produced a darker-hued child labeled torna atrás (literally meaning, "going backwards") revealed the perceived taint of black blood, which meant that Africans could never be redeemed in the way indigenous peoples could. Moreover, critical race studies scholar David Goldberg comments that casta paintings also exposed the fragility of whiteness. If a slight hint of blackness is powerful enough to produce an unsalvageable progeny labeled torna atrás, then "the sense whiteness has of its self-elevation and superiority is fragile indeed." ${ }^{, 767}$ In other words, whiteness requires a continuous (self-) declaration and promotion of its privilege and superiority in order to sustain itself at the top of an unstable racial pyramid. A final point to make here is that the varied and humorous labels for the progeny of other casta combinations, which displayed both the horror and fascination with interracial mixture (lobo, coyote, barcino, albarazado, grifo [of curly hair], torna atrás, tente en el aire [suspended on air], no te entiendo [I don't understand you], etc.), could serve as cautionary tales for viewers to avoid mixing patterns that could dilute Spanish blood to the point of no return. These appellations also betrayed the anxiety of the elite over the impossibility of truly knowing and controlling the population.

The production of casta paintings ended with the Independence movement of 1810. The use of casta designations was banned in legal records in 1822 and in the 1824

${ }^{767}$ Goldberg, The Threat of Race, 209. 
national Constitution, which declared all citizens equal under the law. ${ }^{768}$ The notion of republican citizenship made redundant the practice of differentiating people according to type. Moreover, the founding of the Royal Academy of Fine Arts in 1783 in Mexico City brought about changes in taste and style of painting, which also account for the disappearance of the casta genre. ${ }^{769}$ In fact, painting in the nineteenth century began to focus on ideas of nationhood, which reconfigured the indigenous body and later the mestizo as authentic embodiments of Mexican national identity. ${ }^{770}$

The series Crónica de castas plays with some of these casta designations and creates its own to underscore existing forms of discrimination in Mexico City. For example, the opening credits are designed to look like a casta painting, complete with racial labels that identify the titular characters of each episode (see Appendix B). The first episode is entitled De criolla con mestizo (inverting the traditional gender pattern of the paintings) and features Raúl, who as a taxi driver can navigate spatial boundaries with ease, meeting the upper-class Lucía. Although Raúl and Lucía are the principal and only recurring characters, their story is not always the central focus of the series, nor is it the focus of my analysis. The remainder eight episodes all highlight a different character and her/his experiences of racism, classism and violence in the city. To name but a few episodes: the second episode, entitled De castiza con indio, coyote, features a workingclass, brown teenager who attends private school on a scholarship and is repeatedly taunted by his wealthy, white classmates. The sixth episode, El zapoteco, is about an indigenous Zapotec migrant whose imperfect Spanish is a constant object of derision.

\footnotetext{
${ }^{768}$ Carrera, Imagining Identity in New Spain.

${ }^{769}$ Katzew, Casta Painting.

${ }^{770}$ Stacie G. Widdifield, The Embodiment of the National in Late Nineteenth-Century Mexican Painting (Tucson, AZ: The University of Arizona Press, 1996).
} 
Episode seven, El mazahua y los peregrinos, depicts a brown teenager seeking to reconcile his urban identity, influenced by hip-hop, with his indigenous Mazahua roots. And episode eight, El igualado (insolent), ${ }^{771}$ chronicles the upward mobility of a merchant from Tepito and the anxiety this causes to his former employee.

What is striking about the series is that most of the episodes take place in public spaces, such as the streets and markets, where disorder and conflicts abound. The domestic spaces that we do see are the elegant mansion where Lucía, haunted by the absence of her father, resides with her disaffected and uncaring mother, and the stylish, modern house of the Peñafiel family on the igualado episode, where there is a clear division of labor (the brown maids are expected to remain in the kitchen when not serving the family). The representation of these spaces serves to undermine the notion of order, familial love and harmony that casta paintings sought to convey. In the next section, I describe the setting in which Crónica de castas takes place and then discuss in detail three episodes, which I find to best encapsulate the essence of the series.

\section{Castas in Contemporary Mexico}

Crónica de castas was shot in downtown Mexico City, in the Tepito area, also known as barrio bravo (fierce neighborhood). Tepito is home to the largest and busiest informal market of Mexico - 72 blocks of stalls that sell everything from food to knockoff designer pursues to pirated music and movies. Tepito is as famous for its openair market (which dates back to the colonial era), legendary boxers, street dance parties and devotion to La Santa Muerte (Holy Death) as it is infamous for drugs, guns and vice.

\footnotetext{
${ }^{771}$ The phrase "No seas igualado/a" (Don't be insolent) works to police boundaries; it is meant to remind people of the place in society where they belong. An igualado/a is thus perceived to be stepping out of these established bounds.
} 
The reputation for being a space of criminality and danger has made the barrio the subject of numerous government efforts to "rescue" it. In 2003, then-New York mayor Rudy Giuliani arrived at Tepito at the invitation of multibillionaire Carlos Slim and then Mexico-City mayor Andrés Manuel López Obrador, with the goal of providing his expertise on urban cleansing and renovation. The Mexican government introduced the $M i$ Barrio Tepito proposal in 2007, which was to displace hundreds of families to make way for private capital, including Slim's Inbursa Group and Wal-Mart, in order to improve and modernize the city. ${ }^{772}$ This specific investment project was defeated through the resistance and activism of the locals. ${ }^{773}$

Alfonso Hernández, Tepito's renowned historian and founder of the Center for the Study of Tepito, which runs a public archive, notes with pride that "resistance is in Tepito's DNA" - a point driven by the graffiti-style murals painted on the streets, one of which reads, Tepito existe porque resiste (Tepito exists because it resists). ${ }^{774}$ The politics of resistance that characterize the barrio are poignantly illustrated throughout Crónica de castas, especially on episode five, in which the character of Pointer (Raúl Briones) explains to an outsider his experience of social exclusion: "I defend my right to exist. I

772 Geography scholar Christien Klaufus stresses the importance of paying attention to "the moral connotations of seemingly neutral policy terms such as 'renovation' and 'revitalization,' especially in a Latin American context, where the notions of class, race and territory are historically interconnected." Urban renewal strategies, she continues, "often embrace a race- and class-based notion of visual cleanliness, in which street vendors, indigenous people and beggars [are] regarded as 'polluters' of the cityscape" (Housing and Belonging in Latin America [New York and Oxford: Berghahn Books, 2015], 6).

773 Andalusia Knoll, “The Mexico City Barrio Giuliani Couldn’t Conquer,” Vice, July 3, 2013, accessed March 15, 2015, https://www.vice.com/en_us/article/tepito-is-mexicocitys-last-untamed-barrio.

${ }^{774}$ Hector Becerra, “Mexico City's 'Barrio Bravo' Refuses to Be Conquered," Los Angeles Times, July 21, 2014, accessed March 15, 2015, http://www.latimes.com/world/la-fg-c1-mexico-tepito-20140721-37-story.html. 
was not given anything. Everything was taken from me. This neighborhood is my country. Those are my dead soldiers" - he points to a wall that is known as the "mural of the absent," which features scores of men in dark suits kneeling down as they watch Jesus Christ pass by on a lion-drawn carriage. The mural is meant to memorialize those who have died as a result of the long-running drug war(s). Hernández adds that in a place where few can count on the state for their survival, what keep the barrio standing are the people's ingenuity, hard work and strong social relations. ${ }^{775}$

Crónica de castas was Giménez Cacho's directorial television debut. He is a celebrated Spanish-born, Mexican film actor (Cronos, Y tu mamá también, La mala educación and so on), who has been nominated for a plethora of awards and awarded the Ariel (the Mexican Oscars) four times. He is also a social activist, founder of the cultural collective El grito más fuerte and the En los zapatos del otro campaign, which followed the disappearance of the 43 Mexican normalista students in 2014. He is the type of actor to carry enough cultural capital (in Pierre Bourdieu's sense) in order to launch this type of program. In an interview, he stated that one of the objectives of Crónica de castas was to depict the day-to-day existence of Tepito - to highlight its diversity, cultural richness and uniqueness, without resorting to the usual clichés seen on television. The point was not to idealize the barrio (violence and discrimination are present throughout the series), but to humanize it. In its realist portrayal of Tepito, Crónica de castas captures the concept of "conviviality," which social theorist Paul Gilroy describes as "the processes of cohabitation and interaction that have made multiculture an ordinary feature of urban life

775 Ibid. 
in postcolonial cities." ${ }^{776}$ Gilroy argues that the term "conviviality" is useful because it introduces a measure of distance from the "closed, fixed, and reified" notions of race and identity, "and turns attention toward the always-unpredictable mechanisms of identification." ${ }^{\text {777 }}$ Conviviality does not celebrate the absence of racism, but it recognizes the "creative, intuitive capacity among ordinary people [to] manage tensions" and to forge connections with one another, which can provide a shared sense of belonging. ${ }^{778}$

Giménez Cacho spent a year in the barrio getting to know and gaining the trust of the locals before beginning to film the series. Some of the barrio's residents even make an appearance on the show. The inclusion of brown people in the show is important in itself considering the prevalence of whiteness on Mexican television, in which white actors are viewed as having universal appeal and thus play the dominant roles, while others are relegated to the status of extras. Film studies scholars Ella Shohat and Robert Stam remark that we must pay attention to casting because "as an immediate form of representation, [it] constitutes a kind of delegation of voice with political overtones". 779 Crónica de castas features multidimensional and complex characters played by a diverse group of brown and indigenous people, which serve to contest the normativity of whiteness that often reduces non-white characters to caricatures. Tepito's cultural mainstays, such as the bustling market, the mural of the absent, the shrine of the Holy Death and Las Gardenias soccer team also make an appearance on the show. This team's

${ }^{776}$ Paul Gilroy, After Empire: Melancholia or Convivial Culture? (London and New York: Routledge, 2004), xi.

${ }^{777}$ Ibid.

${ }^{778}$ Amanda Wise and Selvaraj Velayutham, "Conviviality in Everyday Multiculturalism: Some Brief Comparisons Between Singapore and Sydney," European Journal of Cultural Studies, 17 (2014): 407.

${ }^{779}$ Unthinking Eurocentrism, 189. 
players are all trans people who work as cooks and hairdressers in the barrio. The annual game the Gardenias play in October as part of the religious celebration of Saint Francis of Assisi is depicted on the second episode of the series and illustrates the conviviality among the diverse people from Tepito who come together for the love of the game. Moreover, the inclusion of the Gardenias and the recurring trans character of Camilo (Mauricio Isaacs) is important because it provides visibility to a range of sexualities that tend to be subordinated to the figure of the virile, family man in mainstream Mexican media.

A final aspect to highlight here is the Holy Death, embodied in a skeletal form and usually dressed in colorful satin robes as a bride, a nun or a queen, marking her as female saint. The cult of La Santa Muerte only became public in 2001, as it is not sanctioned by the Catholic Church. The fact that some of the Holy Death's most notorious devotees are members of organized crime or are in prison has only made it more difficult for it to be formally recognized. However, religious studies scholar Andrew Chestnut and other writers observe that the majority of the devotees are common people of vulnerable backgrounds, such as working-class mothers, teenagers, street vendors, taxi drivers and prostitutes, who ask her for protection, health, luck, money and sometimes miracles. ${ }^{780}$ The Holy Death embodies hope and the possibility of living a better life. In a country beset by chronic violence, uncertainty and economic, employment

\footnotetext{
${ }^{780}$ Andrew Chestnut, Devoted to Death: The Skeleton Saint (New York and Oxford: Oxford University Press, 2012). Laura Castellanos, "La santa de los desesperados," La Jornada, May 9, 2004, accessed March 15, 2015, http://www.jornada.unam.mx/2004/05/09/mas-santa.html. José Gil Olmos, La santa muerte: La virgen de los olvidados (Mexico: Penguin Random House, 2011). Claudia Reyes Ruiz, "Historia y actualidad del culto a la Santa Muerte," El cotidiano, 169 (2011): 51-57.
} 
and security crises, it is not surprising that the belief in the Holy Death has rapidly increased to the point of rivaling the popularity of the nation's patroness, the Virgin of Guadalupe (of course, the two are not mutually exclusive; most of the Holy Death's followers are also strong Catholics). One of the largest shrines, featuring a life-size statue of the Santa Muerte, is set in the home of long-time Tepito resident Enriqueta Romero, who is tenderly depicted on the second episode of the series.

De castiza con indio, coyote

The second episode begins on a dusty soccer field in Tepito, where various people (girls in cosplay, heavily tattooed men and street vendors) are engaged in a friendly game. The scene cuts to a different soccer game set in a carefully manicured indoor field, where young men in uniform are competing in a tournament. After the gamed ends, Bruno (Pedro de Tavira), Manlio (Rodrigo Corea) and the rest of the team head to the showers. In this intimate space, the boys display both their homoerotic desire for one another and their homophobia. They hide the soap from Manlio and begin to taunt him, slapping his bare ass and using homophobic slurs, such as puto (fag - a word commonly used in soccer games to insult the opposite team). The camera here lingers on Manlio's brown naked body, pointing to the unequal racialized power relations between him and his white teammates - while Manlio is being looked at, the others are doing the looking. ${ }^{781}$ Manlio receives and returns the look, but he does not have the same power to

\footnotetext{
${ }^{781}$ Ann Kaplan and other scholars have noted that looking relations are never innocent because these are "determined by history, tradition, power hierarchies, politics [and] economics." In short, looking is power (Looking for the Other: Feminism, Film and the Imperial Gaze [London and New York: Routledge, 1997], 4. Kaplan, Women and Film: Both Sides of the Camera [London and New York: Routledge, 1983]. Laura Mulvey, "Visual Pleasure and Narrative Cinema," in Film Theory and Criticism: Introductory Readings, ed. Leo Braudy and Marshall Cohen [New York and Oxford: Oxford
} 
act upon it. Visibly irritated, Manlio defends his masculinity by resorting to the same homophobic language and using force to recover his soap. Bruno laughs and says it is only a joke. He then asks: "are you also going to get angry when we call you indio? Dude, you are prieto (dark-brown skin)... get over it, man.” An aspect to note here is that these so-called "only jokes" tend to be perceived as benign and therefore not racist. But in fact, as sociologists Christina Sue and Tanya Golash-Boza point out, such racially tinted humor is a powerful mechanism for "reinforcing systems of domination and inequality." ${ }^{782}$ Moreover, there is a cultural expectation that individuals will go along with these jokes, as evinced in the injunction to "get over it." If Manlio were to react negatively or be hurt by such taunts, then he would be perceived as the problem that gets in the way of these boys having fun and as a disruption to the cherished "project of maintaining national unity."783 Manlio bears the onus of getting over race, ignoring it and willing it into oblivion as though it has never existed and has left no legacy on his body. Manlio thus behaves accordingly - he endures the jokes in silence. According to Sue and Golash-Boza, responses of silence to or engagement with racial jokes "imply an acceptance of the humour, conveying a message that it is unproblematic, which then legitimizes and encourages the continued used of such humour."784 That Bruno

University Press, 1999], 833-844. Ella Shohat, "Imaging Terra Incognita: The Disciplinary Gaze of Empire," Public Culture, 3 [1991]: 41-70. Linda Williams, "When the Woman Looks," in The Dread of Difference: Gender and the Horror Film, ed. Barry K. Grant [2 ${ }^{\text {nd }}$ ed.] [Austin, TX: University of Texas Press, 2015], 17-36).

${ }^{782}$ Christina Sue and Tanya Golash-Boza, "It Was Only a 'Joke:' How Racial Humour Fuels Colour-Blind Ideologies in Mexico and Peru," Ethnic and Racial Studies, 36 (2013): 1595.

${ }^{783}$ Da Costa, "The Un(happy) Objects of Affective Community,” 35. ${ }^{784}$ Sue and Golash-Boza, "It Was Only a 'Joke,'” 1595. 
repeatedly pokes fun at Manlio's skin color, and no one challenges him, reinforces his belief that denigrating anyone darker than himself is an acceptable cultural practice.

Bruno's racism is in full display in a later scene, in which the police stop him for speeding in his ostentatious SUV. In an overbearing manner, he shows his driver's license to the cop, who then recognizes that Bruno is the son of a powerful man and lets him go without a warning, but not before having to bear in silence an array of insults, such as indio, naco (being uncultured or uncouth), ${ }^{785}$ asalariado (literally, having a salary) and nopal (prickly pear cactus - a food associated with the indigenous). Note here how quickly race, class and culture become conflated. In the eyes of a rich, white guy like Bruno, being poor and indigenous are one and the same. Furthermore, the fact that the term "indio" has become a common insult, implying someone is slow or stupid, and addressed at any low-class person, especially of dark complexion, points to the deepseated anti-indigenous prejudice that persists in contemporary Mexico. ${ }^{786}$ While the official ideology of mestizaje proclaims the worth and even superiority of indigenous peoples and cultures, everyday circumstances paint a different picture - one in which indigenous identity continues to be defined in terms of "negative failings - lack of

\footnotetext{
${ }^{785}$ Although the meaning of naco has changed to the point that it now tends to connote an overall urban kitsch aesthetic, it is also a racialized term - a distortion of the word "Totonaco" - that is used to degrade indigenous peoples, peasants and others perceived to embody "the provincial backwardness" that Mexico has sought to dispel (Claudio Lomnitz, "Fissures in Contemporary Mexican Nationalism," Public Culture, 9 [1996]: 55-68). According to cultural critic Carlos Monsiváis, the epithet of naco has become "one of the main vehicles through which the cultural contempt for the Indians is articulated" (Mexican Postcards, 51). Naco is meant to signify people without education or manners, who are ugly, insolent, vulgar and graceless (53). The naco both attracts and repels because in a country where the majority population is mestizo and indigenous, anyone is potentially a naco.

${ }^{786}$ Linda King, Roots of Identity: Language and Literacy in Mexico (Palo Alto, CA: Stanford University Press, 1994).
} 
education, of fluency in Spanish... or other material possessions" ${ }^{9787}$ - and thus of obstructing Mexico’s path to modernity.

\section{El zapoteco}

The sixth episode of the series features the young indigenous teenager Bonifacio (David Illescas), who migrates from the southern state of Oaxaca to the capital city in search of a better life. Once in Tepito, he begins to work in the market as a diablero (meaning, he delivers packages on a dolly from one stall to another), which is the lowest paid job in the barrio. At the market, he meets and falls in love with a local resident named Lola (Alondra Hidalgo). Lola's family, however, rejects Bonifacio because he is indigenous and prohibits her from dating him. Crónica de castas makes a point of showing that it is not only arrogant, rich people like Bruno who harbor and reproduce anti-indigenous sentiment, but it is widespread across Mexico's social strata. Each episode captures the notion of everyday racism. Race studies scholar Philomena Essed observes that everyday racism connects structural and "ideological dimensions of racism with daily attitudes and interprets the reproduction of racism in terms of the experiences of it in everyday life." 788 A central feature of everyday racism is that it "involves racist practices that infiltrate everyday life and become part of what is seen as 'normal.",789 Everyday racism is "heterogeneous in its manifestations but at the same time unified by repetition of similar practices."790 Bonifacio's imperfect Spanish and occupation, for example, are constant objects of ridicule among people in the barrio. Bonifacio endures

\footnotetext{
${ }^{787}$ Knight, "Racism, Revolution, and Indigenismo," 100.

${ }^{788}$ Philomena Essed, Understanding Everyday Racism: An Interdisciplinary Theory (London: Sage Publications, 1991), 3.

${ }^{789}$ Ibid., 288.

${ }^{790}$ Ibid.
} 
in silence the playful taunts of his friends, "of course you're from Oaxaca, you speak so funny," to more overt forms of discrimination, such as when a cop spits at his feet. His recurrent experiences of racism show that "everyday racism does not exist as single events but as a complex of cumulative practices."

In one striking scene, Lola's grandfather launches into a tirade during dinner about why she should not date Bonifacio: "that guy cannot even speak his dialect..."792 "He speaks two languages," Lola corrects him. He continues: "you have no business with that indio that will never stop being an indio. Those people did not evolve." Here biology and culture become entangled. From his point of view, Bonifacio is biologically deficient and thus incapable of learning the ways of the mestizo world. The mom interjects, chuckling: "Lola wants to go back to the countryside," reproducing the stereotype that indigenous peoples belong in rural spaces. Lola snaps and screams: "Don't you see the Indian face that you both have?" Lola's comment and the high angle camera that focuses on the pained facial expressions of the two other characters underscore the instability of identity. In terms of somatic features, there are no visible differences between Bonifacio, Lola and her family. In a separate context, the family could easily slip into being at the receiving end of such racial epithets as "indio." However, they take on an air of superiority because of their literacy in Spanish and occupation, which grants them a higher-class status. As King observes, language and literacy have been crucial themes "in

${ }^{791}$ Ibid.

792 According to historian Linda King, the tendency to refer to indigenous languages as dialects negates "their true linguistic nature." Many Mexican people consider indigenous languages "inferior forms of expression because they are (incorrectly) thought to lack grammar and an alphabet" (Roots of Identity, 61). 
the ideological debate over cultural identity" in Mexico. ${ }^{793}$ Indigenous movements have fought for bilingual education and for the recognition of their languages "as having an equal status with Spanish." ${ }^{, 794}$ However, indigenous languages continue to be associated with poverty and are thus highly stigmatized. Spanish for its part is perceived to be the language of the modern nation that confers social status and prestige to those who possess it. For example, "in the context of passing from an Indian to a mestizo identity, [literacy in Spanish becomes] a hallmark of one's degree of 'civilization' and an important boundary marker between the 'backward' (wild) Indians and the 'advanced' (cultured) mestizos. ${ }^{\$ 795}$ The family in the series repeatedly comments on Bonifacio's broken Spanish in order to mark themselves as different from Bonifacio - positioned as an "Other" that does not belong in the urban space of Tepito - and avoid being mistaken for "indios." As sociologist Hettie Malcomson notes, racism in Mexico is maintained and reproduced by comparing oneself to others, by fixing one's sight "on those individuals who are 'more morenos than' oneself in any given context." 796 Crónica de castas demonstrates in this episode and the next that the categories of dark, brown and moreno/a are never simply reducible to skin color, but always involve culture, dress and language. El mazahua y los peregrinos

Episode seven paints a poignant portrait of a young man named Hipólito and his struggle to reconcile his urban identity, shaped by hip-hop and rap culture, with his

\footnotetext{
793 Ibid., 2.

${ }^{794}$ Ibid., 70.

795 Ibid., 159.

796 Hettie Malcomson, “La configuración racial del danzón: Los imaginarios raciales del puerto de Veracruz," in Mestizaje, diferencia y nación: Lo 'negro' en Américal central y el Caribe, ed. Elisabeth Cunin (Mexico: Instituto Nacional de Antropología e Historia, 2010), 295.
} 
Mazahua origins. We first meet Hipólito at the Tepito market with his mom and friend Nayla, who are both dressed in traditional Mazahua clothing and switch between Spanish and their Mazahua language with ease. Hipólito for his part refuses to speak anything other than Spanish and complains that he cannot understand "that dialect." "[Mazahua] is a language not a dialect," Nayla corrects him. It is clear throughout the episode that Hipólito is conflicted about his identity and has internalized the dominant ideology of mestizaje to the point that he views his own indigenous origins as a shameful condition to overcome. In another scene, when a woman at the market asks Hipólito about why he wears the type of clothing that he does (baggy pants, retro basketball jerseys, large chains), he responds: 'I'm going to a rap concert. I'm not going out dressed like a goddam indio," expressing his discomfort of being associated with the indigenous. The woman retorts: "Well, it wouldn't be a bad idea. People would then know that we are everywhere."

Later in the episode, Hipólito and his girlfriend get in trouble with the cops because the latter was selling drugs outside their school. His mom and Nayla, dressed in their traditional clothing, go to the police precinct to post bail for both teenagers. The girlfriend comments to Hipólito that she now sees why he had not introduced her to his family: "So you're ashamed because they're indias. I didn't know you were the son of the Marías." "Las Marías" is a pejorative nickname that has been used in Mexico City since the 1960 s to describe rural and indigenous migrant women who work as domestics and street vendors. ${ }^{797}$ This nickname serves as a powerful form of homogenizing indigenous women as a group and denying them their individuality. Anthropologist Carmen Martínez

${ }^{797}$ Esquivel et al. La república informal: El ambulantaje en la ciudad de México (Mexico: Miguel Ángel Porrúa, 2008). Rowe and Schelling, Memory and Modernity. 
Novo notes that the so-called Marías have been constructed as outsiders in relation to urban spaces in Mexico, as deviants who engage in an illegal activity (begging) while pretending to be vendors and as a social problem that state authorities must address. ${ }^{798}$ The police are notorious for harassing and removing these women from the streets, perceived to be an obstacle to the modernization of the city. Hipólito's girlfriend reproduces many of these stereotypes. After Hipólito breaks up with her and walks away with Nayla and his mom, the girl stays behind at the precinct yelling a series of epithets: "hijo de Marías limosneras (son of beggars), damn indio, dirty, you stink..." While there are no somatic, class or linguistic differences between this girl and Hipólito's family, she takes on an air of superiority and denigrates these women by virtue of them wearing their traditional dress, which works as a "boundary marker" to separate indigenous peoples from mestizos ${ }^{799}$ Crónica de castas, however, attempts to undermine this rigid boundary by depicting a more complex geographical and social reality - one in which increasing number of indigenous peoples work, live and feel at home in cities at the same time that they maintain ties to their rural communities. As the mom admits: "Well, yes, now all of us Mazahuas are here in the city." Hipólito adds: "Mom, you are even more chilanga ${ }^{800}$ than I am.”

After the painful experience of racism outside the police station, Hipólito begins to reflect on his indigenous origins. That night he dreams that a vagrant on the street addresses him in Mazahua. "How do you know I am Mazahua?" he asks. The man responds: "You cannot deny who you are. Have you forgotten? Do you wish you could

\footnotetext{
798 Martínez Novo, Who Defines Indigenous? 103-104.

${ }^{799}$ King, Roots of Identity, 159.

${ }^{800}$ Chilango/a is a sobriquet for all Mexico City residents.
} 
be white?" The next day, as Hipólito is getting ready to perform in an underground rap battle, he changes his name from MC Hipo to 13 serpientes (snakes) and dons his version of the santiaguero dress ${ }^{801}$ on stage. He raps in a mixture of Mazahua and Spanish and reclaims what previously caused him pain, declaring himself an indio and the son of María. By reconciling his indigenous roots with urban global culture (hip-hop), Hipólito creates a "third space of identity" that breaks down the dichotomy between indigenous peoples and mestizos, and engenders new meanings, social relations and ways of life in the process. ${ }^{802}$ According to anthropologist Charles Hale, the notion of the third space challenges official mestizaje because it "connotes fluidity and openness to a range of possible articulations. ${ }^{" 803}$ This creative third space is never fixed, but is always changing and in a state of becoming.

It is also interesting to note the use of hip-hop culture in this episode. As Latin American studies scholar Josep Cru observes, hip-hop and especially rap have been appropriated and localized by indigenous communities in their efforts to revitalize and de-stigmatize their languages. First, rap as a form has adapted well within the indigenous context because both favor orality over literacy. ${ }^{804}$ Second, because rap as a genre epitomizes "coolness" and modernity for many young people, it can help dispel the dominant ideology that associates indigenous languages with tradition, backwardness and a remote (often pre-Hispanic) past, which separates these languages "from everyday

801 The santiaguero is a traditional dance that dates back to the colonial era.

802 Bhabha, The Location of Culture. Javier Sanjinés, Mestizaje Upside-Down: Aesthetic Politics in Modern Bolivia (Pittsburgh, PA: University of Pittsburgh Press, 2004). ${ }^{803}$ Hale, Más que un indio: Racial Ambivalence and Neoliberal Multiculturalism in Guatemala (Santa Fe, NM: School of American Research, 2006), 179.

${ }^{804}$ Joseph Cru, "Bilingual Rapping in Yucatán, México: Strategic Choices for Maya Language Legitimation and Revitalisation," International Journal of Bilingual Education and Bilingualism, (2015): 4. 
contemporary uses. ${ }^{~} 805$ Bilingual rap in the series is framed as an instrument of pedagogy and resistance that allows Hipólito to express pride in his distinct modern identity, to expose the Mazahua language to a broader audience and to combat linguistic prejudice.

The three episodes discussed here provide a realist representation of how racism, classism and violence are reproduced in everyday social interactions. I focused on language in particular because in its perceived banality, it tends to avoid scrutiny. However, language is a powerful mechanism for reproducing racialized systems of power that can hide beneath the "it's only a joke" veneer to downplay its impact. Because humor is seen as not carrying racist intent and thus benign, ${ }^{806}$ people can resort to using words like "indio" and "naco" at the same time that they can hold on to the ideology that racism does not exist because "we are all Mexican and mixed." What Crónica de castas does so well is to highlight what is undramatically explicit in Mexico: how we so often break each other with words.

\section{Conclusion}

Crónica de castas stands out as an anomaly in the Mexican televisual landscape because it names and engages with the topic of racism in a context that otherwise denies it. The fact that Canal Once, renowned for its educational and cultural programming, picked up the series no doubt provided the production team the creative freedom necessary to produce this type of content. But even then, the series was cut short from 13 episodes to nine because of limited funding and was not renewed for a second season. NBC Universo did broadcast Crónica de castas a year later in the United States, promoting it with the hyperbolic statement, "the series that shook Mexico." It is difficult

\footnotetext{
${ }^{805}$ Ibid.

${ }^{806}$ Sue and Golash-Boza, "It Was Only a 'Joke.”
} 
to gauge the series' impact, but the fact that it was so short-lived points to a lack of interest from both the network and the public.

Nonetheless, Crónica de castas is commendable for providing visibility to what is excluded from mainstream media. First, its cast features an array of brown and indigenous faces in titular roles that would otherwise be relegated to the background of the aspirational white world of telenovelas. In an interview, actor Harold Torres, who plays the protagonist Raúl, acknowledged that his only opportunity in another time would have been to play the chauffeur. "That is something that television has perpetuated, showing a false reality," he concluded. In casting actors that do not conform to AngloEuropean standards of beauty, Crónica de castas seeks to make the normativity of whiteness strange. Second, the series grants status and visibility to indigenous languages that are always subordinated to Spanish. Shohat and Stam point out that as with casting, “issues of self-representation arise in relation to language." ${ }^{807}$ Languages as lived are inscribed within hierarchies of power and culture. ${ }^{808}$ It is interesting to note how Crónica de castas features characters that tell their stories in their indigenous languages, as in the Mazahua episode, thereby contesting the dominance of Spanish. Third, its storylines humanize the lives and customs of the many existing Mexicos that are marginalized from society. Fourth, the series disrupts the enduring binary racial formation of indigenous peoples and mestizos by showing that identities are not fixed or stable, but are rather experienced in a continuum. However, it would have more interesting if Giménez Cacho had handed cameras to the Tepito residents so that they could have not only been actors in their own drama but producers of their own images and narratives. In order to fully

${ }^{807}$ Unthinking Eurocentrism, 191.

${ }^{808}$ Ibid. 
disrupt the dominant regimes of representation, non-white voices have to gain access to the means of production and distribution.

In sum, Crónica de castas is an important critique that undermines mestizaje's claim to mixture as a positive aspect of national identity through its representation of racism as an everyday experience for the Mexicans whose ancestry makes a visible difference. In other words, the series demonstrates that "race, body, and face" matter in the lives of Mexicans, for they shape social relations and determine boundaries of inclusion and exclusion. ${ }^{809}$ As in the colonial period, somatic, linguistic and cultural characteristics continue to play a central role in reproducing socioeconomic inequalities in contemporary Mexico.

${ }^{809}$ Martínez Andrade, Religion Without Redemption, 50. 
Appendix A

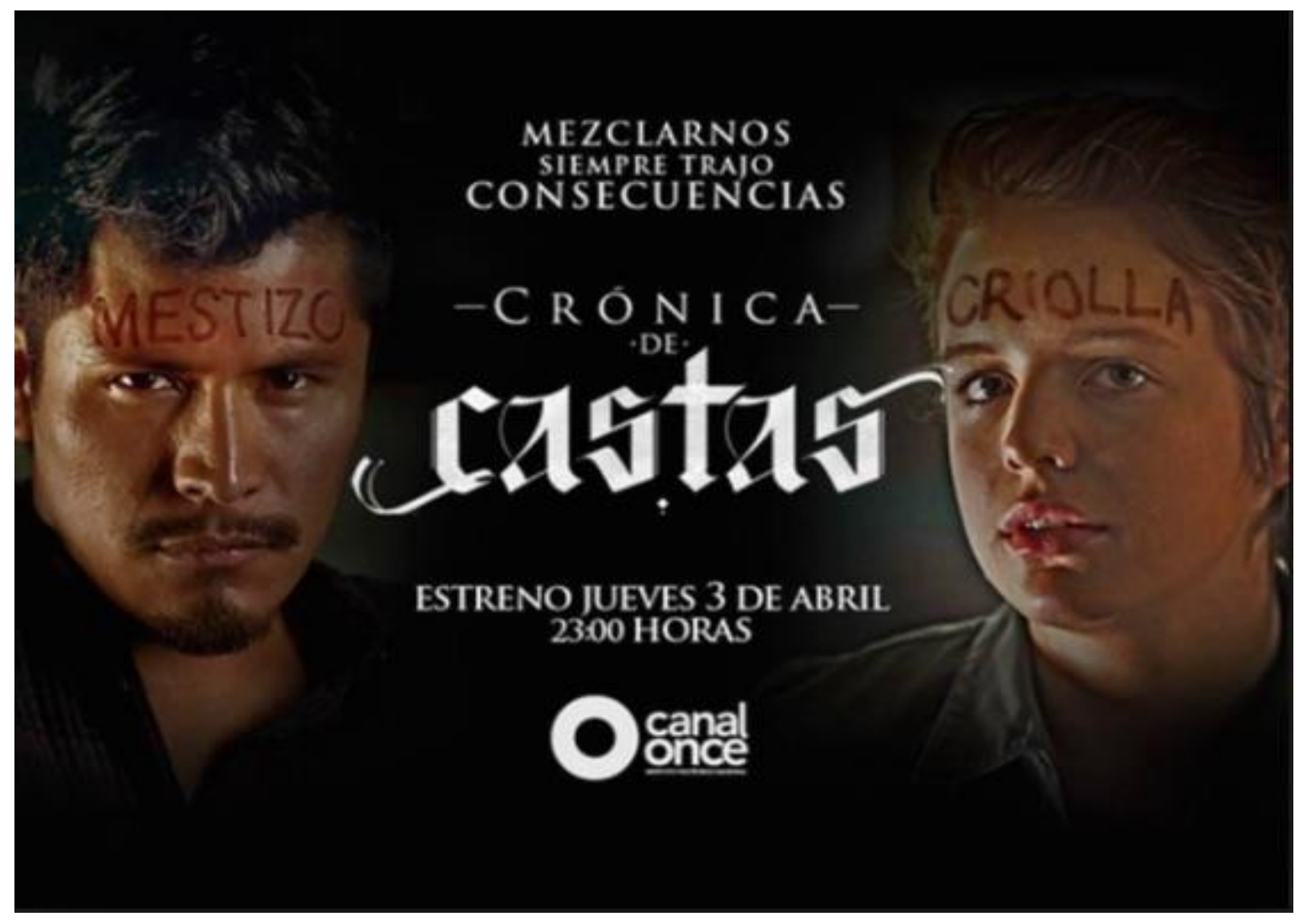

Retrieved from: http://oncetv-ipn.net/cronicadecastas/ (accessed May 30, 2017). 
Appendix B


Retrieved from: http://oncetv-ipn.net/cronicadecastas/episodios.html (accessed May 30, 2017). 


\section{Chapter Nine}

\section{Conclusion}

"What we cannot be is defeatist. Mexicans are a happy, united and hardworking people. We live life with attitude, leaning forward and always ready for whatever comes next; that is what distinguishes us from the rest of the world." - President Enrique Peña Nieto, publicity campaign, 2015-2016.

"I cannot imagine [indigenous people] working in a factory...I cannot imagine you working behind a desk. I picture you in the countryside...in your homes making crafts. I picture you doing the work of your indigenous communities and I know that that is what you want to do. Let's direct the vision of work that you have to those ends because if you decide to abandon your lands and traditions, then the Mexican nation will lose its roots..." - Congresswoman Luz Elena Govea López, addressing indigenous leaders in Guanajuato, 2016. ${ }^{810}$

The aim of this project has been to trace the movement of mestizaje, and the histories that are evoked by this mobility, in order to examine its working mechanisms, material consequences and resilience. I find the term "resilient" to be an apt descriptor of this ideology. Resilience is derived from the Latin resiliens, meaning to "rebound" or to "leap back," and overall denotes the ability to recover from or adjust to change.

Throughout this dissertation, I have attempted to show how mestizaje has traveled, morphed and adapted to the changes that have occurred across time and culture in Mexico. While I began this research with the interest to explore mestizaje's legacy through a textual analysis of Mexican television and telenovelas in particular, tracing this ideology’s historical development and mobility led me to unexpected places. For example, I learned that the histories of anthropology, eugenics and indigenismo were integral to the many projects of national consolidation in Mexico - histories that I would have overlooked if my focus had narrowly remained on television. However, I made a point of including more popular texts to underscore the fact that popular culture does not

${ }^{810}$ See https://www.youtube.com/watch?v=Fce8tdjGbx0. 
exist in a vacuum, but it is implicated in the social construction of race, gender, class and national identity. The discussion of the cinematic figures of Cantinflas and Tin Tan, Miguel Sabido's educational telenovelas, Televisa's Cinderella telenovelas and Canal Once's limited series served to highlight how mestizaje has circulated in the culture at large and has become part of everyday life.

The ideology of mestizaje, which celebrates racial and cultural mixture as a positive aspect of Mexican national identity, was first articulated in the works of various intellectuals, such as Andrés Molina Enríquez, Manuel Gamio and José Vasconcelos, at the beginning of the twentieth century. As I documented in the third and fourth chapters, mestizaje was intimately linked to the development of anthropology as an academic discipline, eugenics, immigration policies and the Ministry of Public Education. With the rapid urban and industrial growth of the 1940s and 50s, mestizaje evolved into the study of mexicanidad, which often turned out to be tortured reflections on Mexico's seeming inability to emerge from its arrested development. Leading intellectuals of this time, such as Samuel Ramos and Octavio Paz, conveniently located the nation's ills in what they perceived to be the deviant psyche of the urban poor mestizo population. In the sixth chapter, I explored the critiques posed against mestizaje and its twin strategy of indigenismo by a more radical generation of anthropologists, who were shaped by the political events of 1968 and the disintegration of the ISI model of development in the 1970s. In the seventh chapter, I examined how mestizaje adjusted to the neoliberal restructuring of the country and the emergence of a populist multicultural discourse in the 1990s. While the anthropologist Guillermo Bonfil Batalla argued that the politics of multiculturalism could be a legitimate and ethical alternative to mestizaje, they proved to 
be an ally to the latter. Mestizaje can recognize the multi-ethnic and cultural composition of Mexico at the same time that it can maintain the supremacy of whiteness intact. Lastly, I analyzed how a contemporary television show exposed mestizaje as an all-inclusive fiction through its representation of racism as an everyday experience for many Mexicans. In all chapters, I paid particular attention to banal language: to how seemingly neutral terms such as "high/low," "improvement," "raise," "elevate," "more/less," "beautiful" and so on become racialized at the moment they seem not to be, making mestizaje all the more binding. In these concluding pages, I continue to reflect on the resilience of mestizaje by exploring the significance of what keeps leaping back in the present. In other words, I focus on current events in order to have a deeper understanding of how the ideological pillars of mestizaje - denial of racism and preference for whiteness - persist today.

Throughout this project, I have demonstrated that mestizaje permeates all aspects of Mexican national culture, from political and intellectual discourses to the mass media. Law professor Ariel Dulitzky observes that the Mexican government has become adept at reproducing mestizaje. For example, the government has argued that the indigenous problem has nothing to do with racial discrimination, but rather with "forms of discrimination derived from the socioeconomic reality." ${ }^{811}$ This line of thinking underscores the willingness to explain social disparities among different racial groups in terms of economics and class, but not race. The official response attempts to minimize and delegitimize the significance of race and racial difference as organizing principles of

${ }^{811}$ Ariel E. Dulitzky, "A Region in Denial: Racial Discrimination and Racism in Latin America," trans. David Sperling, in Neither Enemies nor Friends: Latinos, Blacks, AfroLatinos, ed. Anani Dzidzienyo and Suzanne Oboler (New York: Palgrave MacMillan, 2005), 44. 
society. The government has further contended that the absence of racism "can be corroborated by the absence of both domestic and international complaints [against racial discrimination]." 812 This type of argument deliberately ignores the fact that people are generally unaware of the legal mechanisms available to denounce cases of racial discrimination. Moreover, the low number of racial discrimination complaints may have more to do with the public's suspicion of and lack of confidence in the authorities than with the absence of this phenomenon. The Mexican government has also stated that because mestizaje created a population that is "90 percent mestizo," "there has been no need to legislate [in regards to racism]." ${ }^{813}$ Such statement reproduces the principal ideological tenet of mestizaje: "racism does not exist because we are all Mexican and mixed," which has served as the most useful rhetorical device to manage diversity (invisibilizing the black population in the process), to deny nonwhites the right to dissent and to avoid enacting legislation that addresses racial injustices.

Mestizaje continues to be deployed as proof of harmony among the diverse ethnic and racial groups of Mexico. For example, the recent publicity campaign of President Peña Nieto that is cited in the epigraph paints a picture of "happy" and "united" Mexicans who work together to overcome adversity. However, as it is evident in the congresswoman's speech also cited above, not all races are created equal under mestizaje and each is designated a clear place on the racial pyramid. For instance, the congresswoman essentializes indigenous peoples as poor and rural, reiterating in a patronizing tone that she cannot think of them as belonging in the urban milieu. She therefore condemns indigenous peoples to remain isolated in the countryside and denies

\footnotetext{
812 Ibid., 46.

813 Ibid., 49.
} 
them full citizenship. Meanwhile, indigenous crafts and traditions are celebrated and commoditized as something unique that provides the Mexican nation its authentic essence and roots.

The legacy of mestizaje in Mexico is as pervasive in the mass media as in intellectual and state discourses. For example, its legacy and intersection with anti-black racism were evident on two separate incidents in 2005. The first occurred when then President Vicente Fox, speaking before a group of US businessmen in the coastal town of Puerto Vallarta, noted: "There is no doubt that Mexican men and women, full of dignity, drive and a capacity for work, are doing the jobs that not even blacks want to do there, in the United States." ${ }^{814}$ These remarks were denounced in the US for being racist and insensitive to African-American citizens. Sociologist Jennifer Meri Jones observes that while Fox's comment caused little outrage across Mexico, it was “met with disappointment and frustration by costeños rendered invisible by the comparison. ${ }^{" 815}$ In other words, for Afro-Mexicans, most of whom are concentrated in the coastal regions of Veracruz, Guerrero and Oaxaca (and hence the appellation of costeños), Fox's juxtaposition of Mexican and black workers in the US served to perpetuate the belief widespread in Mexico that being Mexican and black are two mutually exclusive categories. ${ }^{816}$ In a country where black people have been literally written out of the

\footnotetext{
${ }^{814}$ Laurence Iliff and Lennox Samuels, "President Vicente Fox's Comment Reflects Mexican Attitude on Race," The Seattle Times, May 18, 2005, accessed May 30, 2017, http://www.seattletimes.com/nation-world/president-vicente-foxs-comment-reflectsmexican-attitude-on-race/.

815 Jennifer Meri Jones, “'Mexicans Will Take the Jobs that Even Blacks Won’t Do,"” 1565.

${ }^{816}$ Ibid.
} 
national narrative of mestizaje, the discussion on blackness and racism tends to be projected outside of Mexico’s borders. $^{817}$

A few months after Fox's controversial comments, anti-black racism in Mexico once again attracted international attention. At this time, the Mexican Postal Service issued five commemorative stamps featuring the comic book character of Memín Pinguín (see Appendix A). This eponymous comic book that first appeared in Mexico in 1943 was created by the writer Yolanda Vargas Dulché and developed by the cartoonist Sixto Valencia Burgos. The comic revolves around the urban adventures of Memín Pinguín and his three best friends, and was originally intended for the popular classes. Sociologists Mónica Moreno Figueroa and Emiko Saldívar observe that this comic formed part of the state's larger efforts to educate the public. The expansion of education in Mexico "was accompanied by the profound belief that the 'masses' needed to learn to read, write and build a patriotic spirit..." ${ }^{818}$ In other words, the comic strip of Memín Pinguín became a useful device to not only teach the public how to read and write but how to be modern and Mexican. The release of the stamps was meant to commemorate what is considered to be a staple of Mexican popular culture. However, these stamps caused furor all across the US, with the administration of George W. Bush, Reverend Jesse Jackson, Al Sharpton and others condemning what they perceived to be a blatant racist depiction of black people. The accusations from the US in turn provoked a defensive, nationalist sentiment in Mexico, which resulted in the 750,000 stamps issued to sell out within hours in the country's largest cities.

${ }^{817}$ Vaughn, "The African Diaspora through Ojos Mexicanos."

${ }^{818}$ Moreno Figueroa and Saldívar, "“We Are Not Racists, We Are Mexicans,"” 10. 
As Moreno Figueroa and Saldívar observe, many prominent Mexican intellectuals voiced their support for Memín Pinguín. For example, historian Enrique Krauze explained the meaning of this character for Mexicans in an op-ed for The Washington Post. He begins his article by noting that while the US has never had a Native American or African American president, Mexico has had two presidents of indigenous origins and two of its most important leaders have been of African descent. He observes that while Memín Pinguín “appears to be a copy of racist American cartoons[,] to Mexicans, he is a thoroughly likable character, rich in sparkling wisecracks, and is felt to represent not any sense of racial discrimination but rather the egalitarian possibility that all groups can live together." ${ }^{819}$ He proceeds to instruct the US public on how the Spanish method of colonization was more benign, noting that African people in New Spain had more advantages and freedom to work and intermarry than in other European colonies. Krauze concludes with a willfully misguided statement, so characteristic of his writings (see chapter seven): "If Memín Pinguín were a person of flesh and blood, I believe he could win the coming presidential election." ${ }^{820}$ Similarly, leftist intellectual Elena Poniatowska points out, "In our country, the image of blacks awakens an enormous sympathy, reflected in characters like Memín Pinguín...In Mexico, unlike what occurs in the United States, our treatment of blacks has been more affectionate." ${ }^{821}$ Instead of taking the time to reflect on how Memín Pinguín and similar images might offend people of African

\footnotetext{
${ }^{819}$ Enrique Krauze, "The Pride in Memín Pinguín," The Washington Post, July 12, 2005, accessed May 30, 2017, http://www.washingtonpost.com/wpdyn/content/article/2005/07/11/AR2005071101413.html.

${ }^{820}$ Ibid.

${ }^{821}$ Quoted in Fabiola Palapa et al., "Memín Pinguín 'no es el ícono del racismo en México,"' La Jornada, 2005, accessed May 30, 2017, http://www.jornada.unam.mx/2005/07/01/index.php?section=cultura \&article=a04n1cul.
} 
descent, Krauze and Poniatowska choose to downplay the issue of racism by projecting it outward - onto the troubled and well-known racial history of the US. ${ }^{822}$ The rationale here is that Americans are the racist ones, not Mexicans. Meanwhile, Mexico is framed as a mosaic of multiple peoples, cultures and traditions that have converged and coexisted in harmony for a long period of time, which serves to delegitimize the significance of race and the claims to racism in contemporary Mexican society. Moreover, the fact that Memín Pinguín, which looks like a typical "picaninny" figure with its exaggerated phenotypes (bulging eyes, large mouth, protruding lips), is accepted as a likeable and unproblematic character underlines the fact that anti-black racism has become normalized in Mexico, making it difficult to both see and resist.

Anti-black racism was further evident in a 2010 incident in which Televisa actors donned black face during a daytime coverage of the World Cup soccer finals held in South Africa (see Appendix B). Again, these images drew international outrage and criticisms, particularly from the US, which accused Mexico of being racist. However, Televisa spokespeople dismissed such criticisms by employing the "it's only a joke" frame I discussed in the previous chapter, arguing that the actors in blackface "do not signify anything bad" and that "they should not be taken seriously." ${ }^{" 23}$ Moreover, viewers reacted defensively and were quick to point out the moral hypocrisy and double standard of an imperialist country like the US. While the racial history of the US is a valid point of contention, it has tended to be deployed strategically in Mexico and Latin America in general to negate the existence of racism in the region. Latin American studies scholar Tanya Hernández notes that the comparison to the US has been a useful rhetorical device

${ }^{822}$ Moreno Figueroa and Saldívar, “'We Are Not Racists, We Are Mexicans,"” 5.

${ }^{823}$ Sue, Land of the Cosmic Race, 191. 
that allows Latin America to frame racism as foreign, as well as to claim a sense of moral superiority (note, for example, Krauze's boastful statement that Mexico's most famous leaders are of indigenous and African origins) and racial innocence ${ }^{824}$ ("we are all mixed and equal;" "our treatment of blacks has been more affectionate").

Mestizaje's legacy was also palpable in the racist casting call that Catatonia (an advertising company) sent in 2013 on behalf of Aeroméxico (the largest Mexican airline). This casting call specified that it was searching for people of "white complexion," a "Polanco look," "no morenos" and "no accents." The histories of colonialism, nation formation and eugenics that the mobility of mestizaje evokes are all condensed here in Catatonia's speech acts, which articulate the desire to create a white and modern Mexican nation. Moreover, the casting call not only conflates race and class - Polanco is one of the most affluent neighborhoods in Mexico City and thus to be from this neighborhood is to be white and vice versa - but underscores the fact that a strong pigmentocracy prevails across Mexico. Dulitzky and other scholars note that in a pigmentocracy, "a negative value is attached to darker skin color, thus relegating races other than the white race to the lower echelons of society. ${ }^{1825}$ In a pigmentocracy, the darker the skin, the fewer the economic, cultural, educational and social opportunities to succeed in society.

${ }^{824}$ Tanya K. Hernández, Racial Subordination in Latin America: The Role of the State, Customary Law, and the New Civil Rights Response (Cambridge, UK: Cambridge University Press, 2013).

${ }^{825}$ Dulitzky, "A Region in Denial," 48. Hunter, Race, Gender, and the Politics of Skin Tone. Edward Telles, Pigmentocracies: Ethnicity, Race and Color in Latin America (Chapel Hill, NC: The University of North Carolina Press, 2014). 
The legacy of mestizaje was further present in a 2015 Coca-Cola Christmas advertisement, which can be categorized in the "white savior" genre. ${ }^{826}$ The advertisement features a group of young and attractive white people who arrive at Totontepec, an indigenous town in the southern state of Oaxaca, to distribute Coca-Cola bottles and to build a Christmas tree for the community, as the locals watch in awe. The advertisement ends with a scene of harmony: white and indigenous people smile and embrace each other as a message of unity lights up the tree, "Let us become united" (see Appendix C). The advertisement suggests that it is the white people who are able to overcome the nation's prejudices and to reinstate unity among different ethnic, racial and class groups. The legacy of mestizaje was also manifest in the derogatory comments some contestants in the 2016 season of MasterChef México made about indigenous women and domestic workers. For example, one contestant degraded another for working as a maid: "I'm not here to be friends with a domestic worker. I'm sorry, but even in the kitchen there are social codes." It is worth noting that none of the examples I have cited here were without challenge. As it is to be expected in the digital age, these videos went viral and quickly taken down, with the perpetrators of such racist attitudes issuing apologies. On a more official note, Mexico's National Council for the Prevention of Discrimination (CONAPRED) reprimanded the abovementioned congresswoman for reproducing damaging stereotypes about indigenous communities.

As political theorist Antonio Gramsci observes, any hegemonic ideology that has achieved the status of common sense is not a fixed entity, but rather an unfinished

${ }^{826}$ See https://www.youtube.com/watch?v=ziSty_38p6k. 
process that is always contested and historically contingent. ${ }^{827}$ While I have argued that mestizaje has proved to be remarkably resilient over time, I do not intend to suggest that there have not been significant shifts in the Mexican ideological and cultural landscape. For example, the Mexican government established the Citizens' Commission on Discrimination Studies in 2001 and CONAPRED in 2003, with the aim of combating ethnic, racial, gender and other forms of discrimination. Sociologist Christina Sue observes that CONAPRED has made efforts to increase public awareness of racism in the country. For example, CONAPRED launched the First Survey of Discrimination in Mexico in 2005 and a campaign named "Racism in Mexico" in 2011, with the goal of recognizing racism. The campaign plan included Internet, radio and billboard announcements, public performances, workshops and short video clips. One of the most memorable videos featured children sitting in front of a white and brown doll, while a researcher asked them, "which one is pretty?" and "which one is good?" 828 The children associated the white doll with beauty, purity and goodness, which poignantly highlights how the message that "white is right" is internalized from a young age.

Other organizations that have begun to contest the hegemony of mestizaje include the México Negro movement that seeks to provide visibility to Afro-Mexicans and to recover their history. The Collective to Eliminate Racism in Mexico (COPERA), established in 2014 , for its part aims "to make racism visible and public in the country" by way of workshops, campaigns and videos. Moreover, a group of indigenous women have recently announced the creation of the news agency NOTIMIA, which intends to

${ }^{827}$ Antonio Gramsci, Selections from the Prison Notebooks, trans. Quintin Hoare and Geoffrey Nowell Smith (New York: International Publishers, 1992).

${ }^{828}$ See https://www.youtube.com/watch?v=Z341bBS7oj0. 
provide visibility to the struggles of indigenous and Afro-descendant women and to take control over the representation of their communities. Furthermore, the EZLN and the National Indigenous Congress (CNI) have come together to announce that they will participate in the Mexican presidential elections of 2018, with María de Jesús Patricio Martínez as their independent candidate. ${ }^{829}$ It remains to be seen if María's campaign will bring to the surface the implicit racism that lurks in the background and is rooted in the fabric of Mexican society in the way that Barack Obama's presidency did in the US. Additionally, some mass cultural products, such as the television show Crónica de castas that I discussed in the previous chapter, have also begun disrupting the ideological pillars of mestizaje. In the next section, I focus on exploring the relation between mestizaje, racism and death to shed light on the current state of affairs in Mexico.

\section{The Politics of Death in Mexico}

Race and racism may have been named and recognized publicly in Mexico, but these issues always seem to be overshadowed by the myriad of economic and security crises that beset this country, in particular the decade-long drug war. Since the administration of Felipe Calderón (2006-2012) launched the so-called "war on drugs" in 2006, more than 150,000 people have died and another 30,000 have disappeared. Human rights scholar Luis Gómez Romero notes that the death toll in Mexico far exceeds the number of civilians killed in the conflicts in Afghanistan and Iraq between 2007 and

${ }^{829}$ Luciano Concheiro, "Los pueblos indígenas de México eligen a su vocera e irrumpen en el escenario politico," The New York Times, May 28, 2017, accessed June 1, 2017, https://www.nytimes.com/es/2017/05/28/los-pueblos-indigenas-de-mexico-eligen-a-suvocera-e-irrumpen-en-el-escenario-politico/?smid=fb-share-es. 
2014. ${ }^{830}$ The homicide rate in Mexico is now one of the world's highest. Mexico is also one of the most lethal countries in the world to work in the press, with six journalists having already been murdered in 2017.831 While there has been international outrage and mass protests over the murder of these journalists, the execution of 22 civilians in the town of Tlataya and the disappearance of 43 rural students in the state of Guerrero in 2014, many victims of this war have not been identified. Geography scholar Melissa Wright comments that victims remain unnamed because they are not considered to be victims at all. The official discourse considers death and violence to be indicative of the fact that narcos (or drug traffickers) are killing each other off, as well as of the success the military and other government strategies are having in various Mexican cities. ${ }^{832}$ According to the state logic, deaths are evidence of criminals being wiped out by narcoviolence, or the military, and are therefore justified.

As I reflect on the violence, terror and grief the war on drugs has brought to Mexico, I am reminded of the work of postcolonial theorist Achille Mbembe, who argues that the politics of death are ultimately linked to the politics of race. In this section, I am interested in exploring Mbembe's notion of necropower, which he describes as a "work

${ }^{830}$ Luis Gómez Romero, “A Decade of Murder and Grief: Mexico's Drug War Turns Ten," The Conversation, December 11, 2016, accessed March 15, 1027, https://theconversation.com/a-decade-of-murder-and-grief-mexicos-drug-war-turns-ten70036.

${ }_{831}$ David Agren, "Crusading Mexican Journalist Javier Valdez Shot Dead in Sinaloa," The Guardian, May 15, 2017, accessed May 30, 2017, https://www.theguardian.com/world/2017/may/16/crusading-mexican-journalist-javiervaldez-shot-dead-in-sinaloa.

${ }_{832}$ Melissa Wright, "Necropolitics, Narcopolitics, and Femicide: Gendered Violence on the Mexico-US Border," Signs, 36 (2011): 723. 
of death," 833 in order to have a deeper understanding of how race and death operate in tandem in contemporary Mexico.

Before looking into necropower, it is worth reviewing the concept of biopower I introduced in the third chapter. Michel Foucault describes biopower as the state's capacity to "make live" - manage, regulate and optimize life - and "let die" through various techniques of governance. He observes that the emergence of this biopower inscribed racism in the working mechanisms of the state. He defines racism as that which introduces "a break into the domain of life that is under power's control: the break between what must live and what must die." 834 In other words, the primary function of racism is to regulate the distribution of death. Moreover, Foucault notes that the second function of racism is to establish a "biological-type" relationship, whose logic determines that the death of the other (the inferior, the degenerate, the abnormal) is necessary for the optimization of life. ${ }^{835}$ In the economy of biopower, racism becomes "the indispensable precondition" that makes killing acceptable and makes possible "the murderous function of the state." ${ }^{836}$ By "killing," Foucault describes murder as such, but also all other forms of indirect murder, including expulsion, rejection, increasing the risk of death for some, exposing certain people to death and so on. ${ }^{837}$

Mbembe introduces necropolitics as a complement to Foucault's notion of biopolitics, which he sees as insufficient for explaining how life becomes subjugated to

833 Achille Mbembe, "Necropolitics," trans. Libby Meintjes, Public Culture, 15 (2003): 11-40.

${ }^{834}$ Foucault, Society Must Be Defended, 255.

835 Ibid.

836 Ibid., 256.

${ }^{837}$ Ibid. 
the power of death in the periphery countries ${ }^{838}$ Mbembe points to the proliferation of war machines and the existence of death worlds, such as occupied Palestine and apartheid South Africa, where people live in a constant "state of injury" and have effectively become the "living dead," as evidence that the politics of death prevail as a technique of governance in the contemporary world. ${ }^{839}$ In the economy of necropower, sovereignty refers to the ability "to define who matters and who does not, who is disposable and who is not" (emphasis in original) ${ }^{840}$ However, the sovereign right to exercise violence or to kill is no longer the exclusive domain of the state and its army. ${ }^{841}$ New actors with access to the technologies and practices of death include mercenaries, private armies, private security firms, citizen soldiers and urban militias.

Mbembe has influenced various scholars and journalists writing from the perspective of the Latin American periphery. For example, scholars argue that the regulation and distribution of death and violence are interwoven in the fabric of the Mexican state. ${ }^{842}$ Sociologist Magaly Sanchez further notes that violence and neoliberalism are intertwined. While the implementation of neoliberal economic policies in Mexico multiplied the flow of capital, goods, services and employment (especially in assembly plants, or maquiladoras, in the border cities of Tijuana and Juárez), it also led

\footnotetext{
${ }^{838}$ Mbembe, "Necropolitics," 12.

${ }^{839}$ Ibid., 21, 40.

${ }^{840}$ Ibid., 27.

${ }^{841}$ Ibid., 32.

${ }^{842}$ Ariadna Estévez, "The Politics of Death and Asylum Discourse: Constituting Migration Biopolitics from the Periphery," Alternatives: Global, Local, Political, 39 (2014): 75-89. Ioan Grillo, El Narco: Inside Mexico's Criminal Insurgency (London and New York: Bloomsbury Press, 2011). Diego Enrique Osorno, La guerra de los Zetas: Viaje por la frontera de la necropolítica (Mexico: Grijalbo, 2012). Sayak Valencia Triana, "Capitalismo gore: Narcomáquina y performance de género," e-misférica, 8 (2011), accessed February 15, 2017, http://hemisphericinstitute.org/hemi/es/e-misferica$\underline{82 / \text { triana. }}$
} 
to an upsurge in structural violence, causing "rampant economic inequality, social exclusion, and persistent poverty." ${ }^{843}$ Structural violence in turn yielded to a rise in criminal violence, manifested in the form of drug cartels, youth gangs and mafias. ${ }^{844}$ Journalist Ioan Grillo similarly observes that the proliferation of drug gangs, whose lieutenants and foot soldiers tend to be under 25 years old, is the result of the youth's "systematic alienation over the last two decades." 845 In a country where the poor and young can no longer rely on the government for social safety nets, it is not difficult to see why they may be seduced by what the cartels can offer: money, guns, commodities and a sense of purpose. According to cultural studies critic Sayak Valencia, the issue of drug trafficking is used to justify the state's large national security budget and its simultaneous funding cuts for health, educational, cultural and employment services, thereby "contributing to a greater tear of the social fabric and feeding the cycle of povertyviolence." 846

Mexican drug cartels consolidated their power amid the collapse of their country's economy and "the gold rush of globalization" in the $90 \mathrm{~s} .{ }^{847}$ The fact that US authorities curtailed the Colombian cartels' trading routes through the Caribbean and South Florida also enabled Mexican cartels to take control over the distribution business, thus further empowering them. Their power is such that Mexican drug cartels now share with the state the techniques of death to instill terror and dominate the population. As Grillo points out, murder has become the second largest product after drugs for the

\footnotetext{
${ }^{843}$ Magaly Sanchez, "Insecurity and Violence as a New Power Relation in Latin America," The Annals of the American Academy of Political Science, 606 (2006): 179. ${ }^{844}$ Ibid. ${ }^{845}$ Grillo, El Narco, 166.

846 Valencia Triana, "Capitalismo gore."

${ }^{847}$ Grillo, El Narco, 75.
} 
cartels. Public displays of violence and intimidation, such as executions, kidnappings, torture and persecutions, have become part of everyday life in Mexico. Perhaps the most public display of necropower has been the propagation of the so-called "narco-fosas" (narco-tombs) across the country, where dismembered, tortured and anonymous bodies appear piled on top of each other. These bodies for the most part remain unidentified and unnamed. The government responds by militarizing daily life - and the "narco-machine" keeps on turning. ${ }^{848}$

The mutilated bodies of rural students, working-class women and undocumented migrants found in street tombs across Mexico underscores how marginalized people have become disposable in a necropolitical economy. Anthropologist Mariana Mora further notes that under the logic of neoliberalism, the "bodies of young, impoverished, primarily indigenous [peoples], are devalued in relation to other bodies, [and can thus] be easily disposed of and forgotten." ${ }^{, 849}$ For example, Central American migrants seeking to make it into the US are often subjected to an array of human rights abuses when they arrive in Mexico, perpetrated by both the authorities and the cartels. The latter has branched out into various forms of organized crime that includes kidnappings of migrants in order to extort or recruit them as hitmen. The Mexican government for its part has responded by implementing mass deportation policies and increasing its border security, with more checkpoints on highways and raids on hotels frequented by migrants, ${ }^{850}$ which has led to

\footnotetext{
${ }^{848}$ Rossana Reguillo, "La narcomáquina y el trabajo de la violencia: Apuntes para su decodificación," e-misférica, 8 (2011), accessed February 15, 2017, http://hemisphericinstitute.org/hemi/es/e-misferica-82/reguillo.

${ }_{849}$ Mariana Mora, "Ayotzinapa and the Criminalization of Racialized Poverty in La Montaña, Guerrero, Mexico," Political and Legal Anthropology Review, 40 (2017): 68. 850 Mexican authorities deported an estimated 200,000 Central American migrants in 2015 (Kate Linthicum, "More Central Americans are Giving Up on the U.S. and Looking
} 
a rising tide of human rights complaints. The culture of impunity that prevails underlines how Central Americans in Mexico do not count as fully human and their exploitation is therefore justified in order to protect the security of the Mexican nation. The crackdown on migration has also led to a rise in the harassment of Mexican rural and indigenous peoples from the impoverished state of Chiapas, many of whom have been detained on buses or the streets solely based on their physical features, clothes and appearance. ${ }^{851}$ Some of these people remain in detention centers for weeks before they can convince migration officials that they are not Central American but Mexican nationals.

In her study of globalization and the femicide crisis in northern Mexico, Wright observes that the politics of gender, as much as race, are intimately linked to the politics of death. ${ }^{852}$ She remarks that the Mexican government's lack of interest in solving the femicides has to do with the fact that it does not view these women as victims worthy of much attention. For example, the Chihuahua governor Francisco Barrio noted in 1995 that the murder rate fell within the norm for an industrial city like Juárez. ${ }^{853}$ Moreover, he reassured Mexican families that there was nothing to fear as long as they remained vigilant of their female family members. ${ }^{854}$ The police for its part argued that the women who had disappeared and been murdered were most likely leading "double lives," that is,

Instead to a Mexican Dream," Los Angeles Times, December 1, 2016, accessed May 30, 2017, http://www.latimes.com/sdhoy-more-central-americans-are-giving-up-on-the-u-sand-looking-instead-to-a-mexican-dream-20161203-story.html).

${ }^{851}$ Nina Lakhani, "Mexico Tortures Migrants - And Citizens - in Effort to Slow Central American Surge," The Guardian, April 4, 2016, accessed March 15, 2017, https://www.theguardian.com/world/2016/apr/04/mexico-torture-migrants-citizenscentral-america.

${ }^{852}$ Wright, Disposable Women and Other Myths of Global Capitalism (New York and London: Routledge, 2006).

${ }^{853}$ Wright, "Necropolitics, Narcopolitics, and Femicide," 712.

${ }^{854}$ Ibid., 713. 
they were factory workers by day and prostitutes by night, and so they "got what they asked for." ${ }^{955}$ Wright points out that factory workers have tended to be associated with prostitutes because of the fact that both work outside the home and inhabit the public sphere. The characterization of factory workers as public women relies on a negative framing of prostitution as a form of pollutant to families, communities and nations that must be eliminated. ${ }^{856}$ Wright and other scholars further contend that the discourse on public women, taken to its logical extreme, allows the Mexican government and authorities to rationalize that the deaths of these women "represent a kind of [urban] cleansing, as the removal of troublesome women restores the moral and political balance of society. ${ }^{857}$ In other words, this discourse that frames the murder victims as criminals is deployed to justify and normalize gender violence. Latino/a Studies scholar Lisa Marie Cacho observes that in general, the criminalization of marginalized bodies serves to justify their "ineligibility to personhood because it takes away the right to have rights." 858 This denial of personhood then determines whose lives matter and whose do not; whose lives have social value, and are thus worthy of protection, and whose do not.

\footnotetext{
855 Ibid., 714.

856 Ibid., 713.

${ }^{857}$ Ibid. Alicia Schmidt Camacho, "Ciudadana X: Gender Violence and the Denationalization of Women's Right in Ciudad Juárez, Mexico," in Terrorizing Women: Feminicide in the Américas, ed. Rosa Linda Fregoso and Cynthia Bejarano (Durham and London: Duke University Press, 2010), 275-289. Héctor Domínguez-Ruvalcaba and Patricia Ravelo Blancas, "Obedience without Compliance: The Role of Government, Organized Crime, and NGOs in the System of Impunity that Murders the Women of Ciudad Juárez," in Terrorizing Women: Feminicide in the Américas, trans. Sara Koopman, ed. Rosa Linda Fregoso and Cynthia Bejarano (Durham and London: Duke University Press, 2010), 182-196.

${ }^{858}$ Lisa Marie Cacho, Social Death: Racialized Rightlessness and the Criminalization of the Unprotected (New York: New York University Press, 2008), 8.
} 
In these concluding pages, I thought it was important to discuss how the politics of race, gender and death are all entangled in order to shed light on their relation to mestizaje in contemporary Mexico. As Mora points out, mestizaje "requires the continued presence of the indigenous Other as a source of permanent extraction of racialized cultural differences in order to justify the very negation of indigeneity." 859 Without the presence of this marginalized "other," then the mestizo as a social category begins to disappear. ${ }^{860}$ In other words, the mestizo nation-state requires the existence of these impoverished, criminalized and racialized indigenous bodies in order to sustain its fragile superiority. The mestizo nation-state can reclaim its power by disciplining and controlling these bodies. ${ }^{861}$ Moreover, the deaths of migrants, factory mestiza workers, indigenous peoples and rural students highlight the centrality of race to what Judith Butler calls the "differential distribution of precarity." 862 She explains that those whose lives are not perceived "as potentially grievable, and hence valuable, are made to bear the burden of starvation, underemployment, legal disenfranchisement, and differential exposure to violence and death." 863 The loss of those whose lives are not recognized as human lives in the first place, and are thus cast as ungrievable, is deemed necessary to protect the lives of those who do count as "living." "864 Although writing from different contexts, all the theorists cited above are essential readings for understanding the unequal distribution of death in Mexico.

\footnotetext{
${ }^{859}$ Mora, "Ayotzinapa and the Criminalization of Racialized Poverty," 78. ${ }^{860}$ Ibid.

861 Ibid., 79.

862 Judith Butler, Frames of War: When is Life Grievable? ( ${ }^{\text {rd }}$ ed.) (London and New York: Verso, 2016), 25.

${ }^{863}$ Ibid.

${ }^{864}$ Ibid., 31.
} 


\section{Coda: Looking Ahead}

At the time of writing this conclusion, the autocratic president Donald Trump has signed two executive orders to prevent Muslims and Mexicans from entering the US. Both groups had been demonized and cast as threats to the security of the US nation since he announced his candidacy. The next four years will require an unrelenting amount of energy and activism to resist the policies of his administration that seek to normalize racism. Caribbean studies scholar Silvio Torres-Saillant points out that Latina/o scholars working outside Latin America must also remember to remain vigilant of their home countries and denounce exclusionary policies with the same political urgency that they exhibit in their examination of US society. ${ }^{865}$ By taking a more lenient approach to the analysis of their countries of origin, Latina/o scholars run the risk of reproducing the notion of racial innocence endemic to mestizaje. It is imperative, for example, for a Mexican scholar to be as critical of the US (mis-) treatment of Mexican immigrants as of Mexico's own demonization of Central American migrants and increased militarization of its southern border. It is imperative to be critical of president Peña Nieto, of his neoliberal policies that have exacerbated the poverty of the already marginalized, and of his complete lack of regard for people's suffering, evident in his tone-deaf publicity campaign cited in the epigraph, in which he admonishes the public for focusing on the bad (e.g. gas shortages) rather than the good his administration has to offer (the slogan goes, "Lo bueno casi no se cuenta, pero cuenta mucho"["The good things are almost never told, but they count a lot"]). The situation on both sides of the border and across the

${ }^{865}$ Silvio Torres-Saillant, "Racism in the Americas and the Latino Scholar," in Neither Enemies nor Friends: Latinos, Blacks, Afro-Latinos, ed. Anani Dzidzienyo and Suzanne Oboler (New York: Palgrave MacMillan, 2005), 281-304. 
world underscores the importance of an academic discipline such as critical race studies that strives to challenge the working mechanisms of race and racism in order to create a more humane and just society.

The aim of this project has been to explore how mestizaje and its ideological fictions have developed and operated in Mexico in order to challenge their hegemony. I have not intended to displace this system of ideas with a new one, nor to suggest that a politics of multiculturalism is the solution to mestizaje. What I have done is to problematize and provide visibility to the issues of race and racism in a context that otherwise denies them. I consider this dissertation to be a modest contribution to the fields of critical race and Latin American studies that have begun to imagine and inspire political alternatives.

While the study of mestizaje (including mine) has tended to focus on how this ideology denigrates indigenousness and blackness to maintain the supremacy of whiteness, future research on this subject could benefit from exploring what it means to be mestizo to different people across Mexico, as the sociologist Moreno Figueroa has begun doing in her work. ${ }^{866}$ The emergent scholarship on the Afro-descendant population in southern Mexico are also important because they seek to provide visibility to this marginalized community and to recover their history and contributions to the making of the Mexican nation. ${ }^{867}$ Although my research materials did not engage much with the

\footnotetext{
${ }^{866}$ Moreno Figueroa, "'Linda Morenita."”

${ }^{867}$ Malcomson, "La configuración racial del danzón.” Meri Jones, "Mexicans will take the jobs that even blacks won't do." Sue, Land of the Cosmic Race. Vaughn, "The African Diaspora through Ojos Mexicanos." Ben Vinson III, "Black Mexico and the Historical Discipline," in Black Mexico: Race and Society from Colonial to Modern Times, ed. Matthew Restall and Ben Vinson III (Albuquerque, NM: University of New Mexico Press, 2009), 1-15. Peter Wade, “La presencia de lo 'negro' en el mestizaje," in
} 
African influence in Mexico, I did not intend to reify the mestizo-indigenous binary, but rather to underscore how pervasive it is in the collective imaginary. Moreover, it would be interesting to conduct research on whiteness and regional identities in northern Mexico, where the tendency to identify as white and to correlate this whiteness with progress, industrial development and modernization is more prevalent than in other parts of the country.

Mestizaje is a rich topic of research that can be approached from many different perspectives, disciplines and methodologies. As per the examples cited in this conclusion and throughout this research project, it is evident that mestizaje continues to be entrenched in the Mexican national and cultural imaginary. It is thus important that we as scholars work together and with a strong political commitment to scrutinize this ideology in order to destabilize it and to begin building more egalitarian societies, or, to borrow the words of the neo-Zapatista movement, in order to begin "constructing a world in which many worlds fit."

Mestizaje, diferencia y nación: Lo 'negro' en Américal central y el Caribe, ed. Elisabeth Cunin (Mexico: Instituto Nacional de Antropología e Historia, 2010), 107-127. 
Appendix A

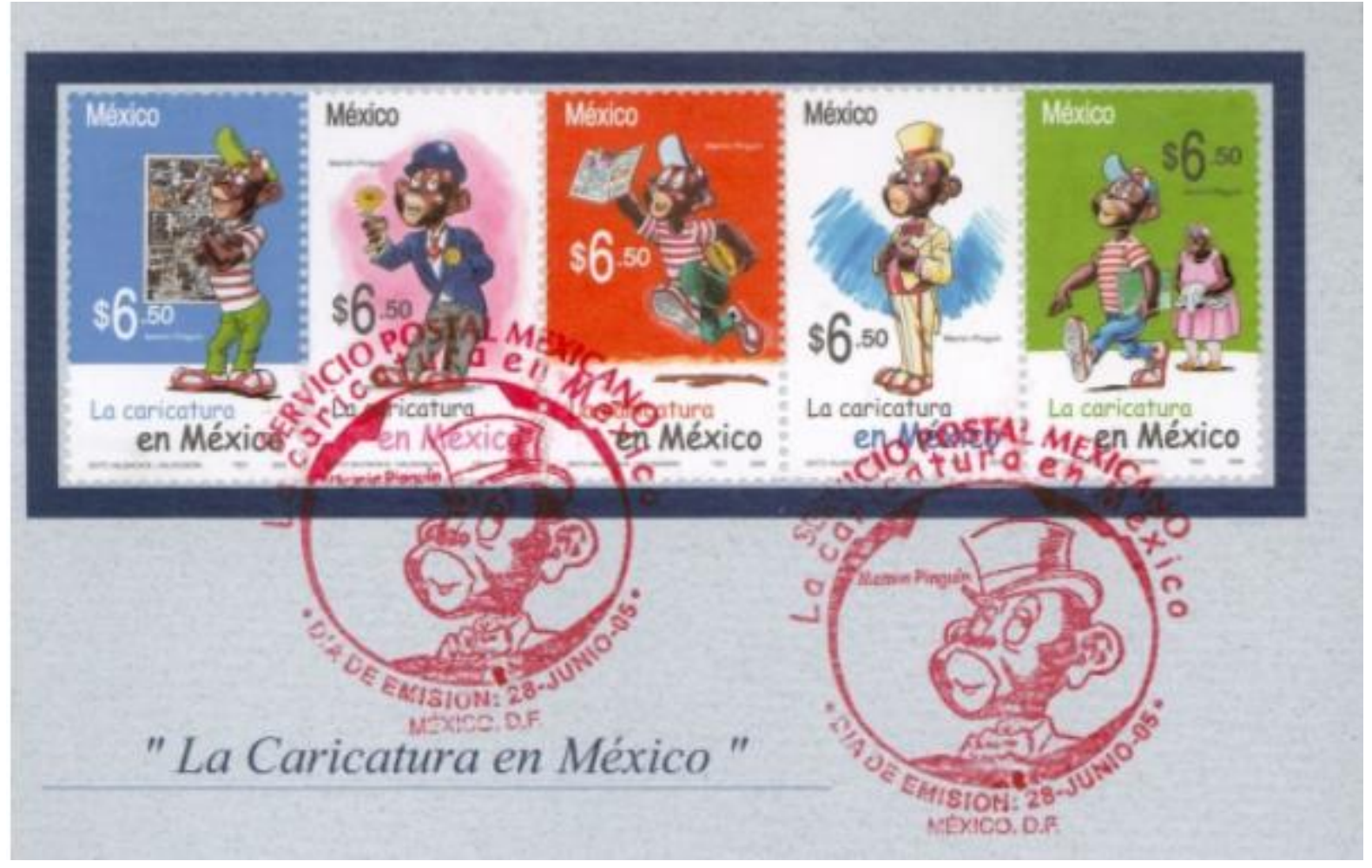

Retrieved from: http://www.capital21.cdmx.gob.mx/adios-a-sixto-valencia-creadorgrafico-de-memin-pinguin/ (accessed May 30, 2017). 
Appendix B

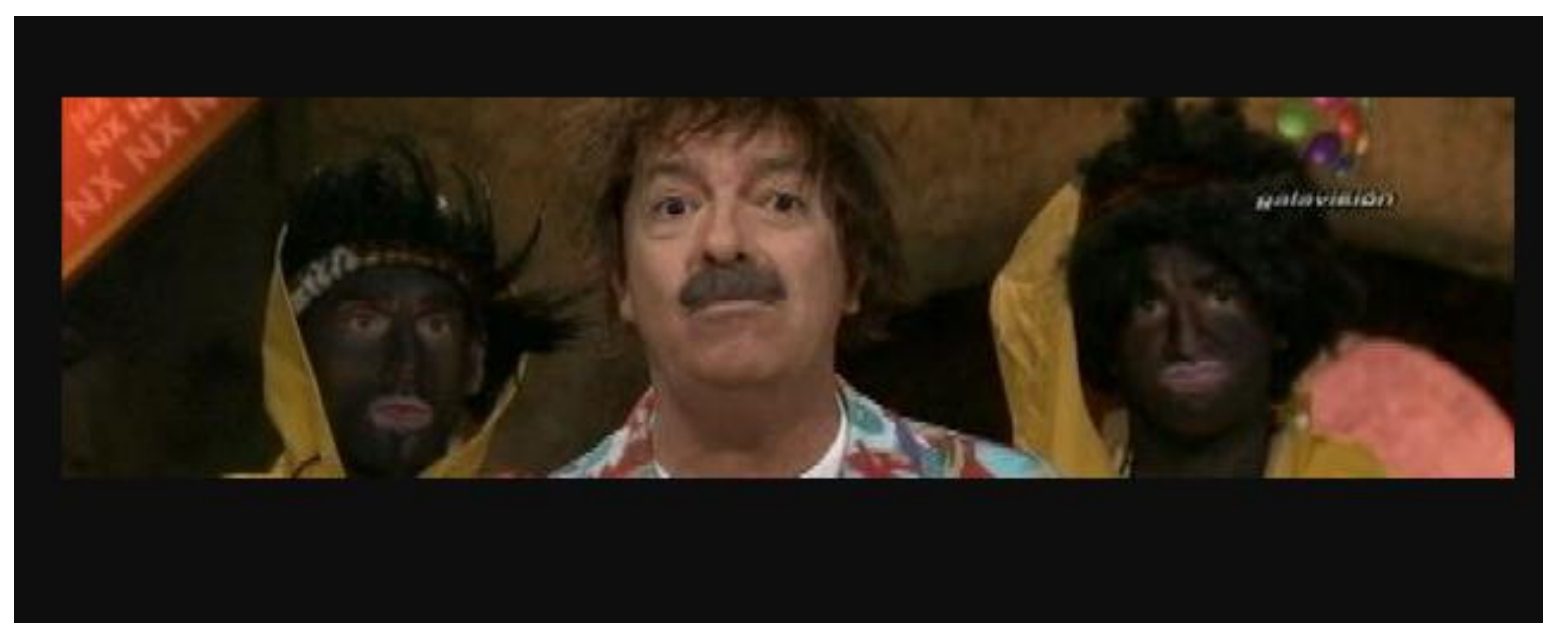

Retrieved from: http://latimesblogs.latimes.com/laplaza/2010/07/mexico-race-racismblack-face-televisa.html (accessed May 30, 2017). 
Appendix C


Retrieved from: https://news.vice.com/article/a-racist-coca-cola-christmas-ad-in-mexicodisappears-from-youtube (accessed May 30, 2017). 


\section{Bibliography}

Agren, David. “Crusading Mexican Journalist Javier Valdez Shot Dead in Sinaloa," The Guardian, May 15, 2017. Accessed May 30, 2017, https://www.theguardian.com/world/2017/may/16/crusading-mexican-journalist-javiervaldez-shot-dead-in-sinaloa.

Ahmed, Sarah. "Declarations of Whiteness: The Non-Performativity of Anti-Racism." Borderlands, 5 (2004). Accessed February 15, 2014, http://www.borderlands.net.au/vol3no2_2004/ahmed_declarations.htm.

Ahmed, Sarah. The Promise of Happiness. Durham and London: Duke University Press, 2010.

Alarcón, Norma. "Traddutora, Traditora: A Paradigmatic Figure of Chicana Feminism.” Cultural Critique, 13 (1989): 57-87.

Alarcón, Norma. “Chicana Feminism: In the Tracks of 'the’ Native Woman.” In Living Chicana Theory, edited by Carla M. Trujillo, 371-381. San Antonio, TX: Third Woman Press, 1998.

Allen, Robert. (Ed.) “Introduction.” In To Be Continued...Soap Operas Around the World. London and New York: Routledge, 1995.

Alonso, Ana María. “Territorializing the Nation and 'Integrating the Indian': 'Mestizaje' in Mexican Official Discourses and Public Culture," in Sovereign Bodies: Citizens, Migrants, and States in the Postcolonial World, edited by Thomas Blom Hansen and Finn Stepputat, 39-60. Princeton, NJ: Princeton University Press, 2005. Alvarez, Luis. (2008). The Power of the Zoot: Youth Culture and Resistance During World War II. Berkeley and Los Angeles: University of California Press. 
Amado, María L. “The New 'Mestiza,' the Old Mestizos: Contrasting Discourses on Mestizaje." Sociological Inquiry, 82 (2012): 446-459.

Amaya, Hector. "Machismo in Cultural Criticism: Racializing Post-Revolutionary

Mexican Masculinities.” Paper presented at the International Communication

Association, San Francisco, CA, 2007. Accessed May 15 2014,

http://citation.allacademic.com/meta/p_mla_apa_research_citation/1/7/1/8/8/p171883_in

dex.html.

Anderson, Benedict. Imagined Communities ( $3^{\text {rd }}$ ed.). London and New York: Verso, 2006.

Anthias, Floya and Nira Yuval-Davis. Racialized Boundaries: Race, Nation, Gender, Colour and Class and the Anti-Racist Struggle. London and New York: Routledge, 1992. Anzaldúa, Gloria. Borderlands/La frontera: The New Mestiza. San Francisco, CA: Aunt Lute Books 1987.

Aréchiga Córdoba, Ernesto. “Educación, propaganda o ‘dictadura sanitaria’: Estrategias discursivas de higiene y salubridad pública en el México posrevolucionario, 1917-1945” [Education, Propaganda or "Sanitary Dictatorship": Discursive Strategies of Hygiene and Public Health in Postrevolutionary Mexico, 1917-1945]. Estudios de Historia Moderna y Contemporánea de México, 33 (2007): 57-88.

Armstrong, Nancy. Desire and the Domestic Fiction: A Political History of the Novel. New York and Oxford: Oxford University Press, 1987.

Arrizón, Alicia. Queering Mestizaje: Transculturation and Performance. Ann Arbor, MI: The University of Michigan Press, 2006. 
Balibar, Etienne. "Racism and Nationalism.” Translated by Chris Turner. In Race, Nation, Class: Ambiguous Identities, edited by Etienne Balibar and Immanuel Wallerstein, 37-68. London and New York: Verso, 1988.

Basave Benítez, Agustín. México mestizo: Análisis del nacionalismo mexicano en torno a la mestizofilia de Andrés Molina Enríquez [Mestizo Mexico: Analysis of Mexican Nationalism in Regards to the Mestizophilia of Andrés Molina Enríquez]. Mexico: Fondo de Cultura Económica, 1992.

Becerra, Hector. “Mexico City’s ‘Barrio Bravo’ Refuses to Be Conquered.” Los Angeles Times, July 21, 2014. Accessed March 15, 2015, http://www.latimes.com/world/la-fg-c1mexico-tepito-20140721-37-story.html.

Behdad, Ali. A Forgetful Nation: On Immigration and Cultural Identity in the United States. Durham and London: Duke University Press, 2005.

Beljuli Brown, Lisa. Body Parts on Planet Slum: Women and Telenovelas in Brazil. London and New York: Anthem Press, 2011.

Benamou, Catherine L. "Televisual Melodrama in an Era of Transnational Migration:

Exporting the Folkloric Nation, Harvesting the Melancholic-Sublime." In Latin American Melodrama: Passion, Pathos, and Entertainment, edited by Darlene J. Sadlier, 139-172. Urbana and Chicago, IL: University of Illinois Press, 2008. Benavides, Hugo. Drugs, Thugs, and Divas: Telenovelas and Narco-Dramas in Latin America. Austin, TX: University of Texas Press, 2008.

Berlant, Lauren. The Anatomy of National Fantasy: Hawthorne, Utopia, and Everyday Life. Chicago, IL: The University of Chicago Press, 1991. 
Berlant, Lauren. The Queen of American Goes to Washington City: Essays on Sex and Citizenship ( $3^{\text {rd }}$ ed.). Durham and London: Duke University Press, 2005.

Bhabha, Homi. The Location of Culture. London and New York: Routledge, 1994.

Billig, Michael. Banal Nationalism. London: Sage Publications, 1995.

Billig, Michael. "Discursive, Rhetorical and Ideological Messages.” In Discourse Theory

and Practice: A Reader, edited by Margaret Wetherell, Stephanie Taylor and Simeon J.

Yates, 210-221. London: Sage Publications, 2001.

Bliss, Katherine. "For the Health of the Nation: Gender and the Cultural Politics of Social Hygiene in Revolutionary Mexico." In The Eagle and the Virgin: Nation and Cultural Revolution in Mexico, 1920-1940, edited by Mary K. Vaughan and Stephen E. Lewis, 196-218. Durham and London: Duke University Press, 2006.

Bindman, David. Ape to Apollo: Aesthetics and the Idea of Race in the Eighteenth Century. London, UK: Reaktion Books LTD, 2002.

Bloch, Avital H. "The Journal Vuelta and the Emergence of Mexican Neoconservatism." In Public intellectuals in contemporary Latin America, edited by Avital H. Bloch, Rogelio de la Mora and Hugo Cancino, 148-168. Mexico: Universidad de Colima, 2007. Bonfil Batalla, Guillermo. México Profundo: Reclaiming a Civilization. Translated by Philip A. Denis. Austin, TX: University of Texas Press, 1996.

Bonnett, Alastair. "A White World? Whiteness and the Meaning of Modernity in Latin America and Japan." In Working Through Whiteness: International Perspectives, edited by Cynthia Levine-Rasky, 69-105. New York: State University New York Press, 2002. Borsa, Joan. "Towards a Politics of Location: Rethinking Marginality." Canadian Woman Studies/Les Cahiers de la Femme, 11 (1990): 36-39. 
Brading, David A. Prophecy and Myth in Mexican History. Cambridge, UK: Centre of Latin American Studies, University of Cambridge, 1984.

Brading, David A. "Manuel Gamio and Official Indigenismo in Mexico," Bulletin of Latin American Research, 7 (1988): 75-89.

Brading, David A. Octavio Paz and the Poetics of Mexican History. Translated by Antonio Saborit. Mexico: Fondo de Cultura Económica, 2002.

Brewster, Claire. "The Student Movement of 1968 and the Mexican Press: The Cases of 'Excélsior' and 'Siempre!’'Bulletin of Latin American Research, 21 (2002): 171-190.

Brewster, C. "Mexico 1958: A Crisis of National Identity.” In Cultural History and Literary Imagination, edited by Christian Emden and David Midgley, 149-178. New York: Peter Lang Publishing, 2010.

Brodkin, Karen. "Global Capitalism: What's Race Got to Do With It?" American Ethnologist, 27 (2000): 237-256.

Brown, Wendy. "Neo-Liberalism and the End of Liberal Democracy." Theory \& Event, 7 (2003): 1-25.

Brown, Wendy. Undoing the Demos: Neoliberalism's Stealth Revolution. Brooklyn, NY: Zone Books, 2015.

Buscaglia-Salgado, José F. Undoing Empire: Race and Nation in the Mulatto Caribbean. Minneapolis, MN: University of Minnesota Press, 2003.

Burton, Antoinette. (Ed.) "Introduction: Archive Stories, Archive Fever." In Archive Stories: Facts, Fictions, and the Writing of History, 1-24. Durham and London: Duke University Press, 2005. 
Butler, Judith. Frames of War: When is Life Grievable? ( $3^{\text {rd }}$ ed.). London and New York: Verso, 2016.

Buxton, Claude E. (Ed.) Points of View in the Modern History of Psychology. London and New York: Academic Press, Inc., 1985.

Cacho, Lisa Marie. Social Death: Racialized Rightlessness and the Criminalization of the Unprotected. New York: New York University Press, 2008.

Canessa, Andrew. "Sex and the Citizen: Barbies and Beauty Queens in the Age of Evo Morales.” Journal of Latin American Cultural Studies, 17 (2008): 41-64.

Carey, Elaine. Plaza of Sacrifices: Gender, Power, and Terror in 1968 Mexico.

Albuquerque, NM: University of New Mexico Press, 2005.

Carrera, Magali M. “Locating Race in Late Colonial Mexico.” Art Journal, 57 (1998):

$36-45$.

Carrera, Magali M. Imagining Identity in New Spain: Race, Lineage, and the Colonial Body in Portraiture and Casta Paintings. Austin, TX: University of Texas Press, 2003. Carrington, Ben. “'Race,' Representation and the Sporting Body.” Conference paper for the Centre for Urban and Community Research Series, London, UK, 2002. Accessed May 30, 2015, https://www.gold.ac.uk/media/documents-by$\underline{\text { section/departments/research-centres-and-units/research-centres/centre-for-urban-and- }}$ comm/carrington.pdf.

Castañeda, Estefanía. "Organización familiar en la casa" [Family Organization in the Home]. El Maestro, 1 (1921): 73-75.

Castellanos, Laura. "La santa de los desesperados" [The saint of the desperate]. 
La Jornada, May 9, 2004. Accessed March 15, 2015,

http://www.jornada.unam.mx/2004/05/09/mas-santa.html.

Challis, Debbie. “The Ablest Race': The Ancient Greeks in Victorian Racial Theory.” In Classics and Imperialism in the British Empire, edited by Mark Bradley, 94-120. New York and Oxford: Oxford University Press, 2010.

Chang, Jason. Chino: Anti-Chinese Racism in Mexico, 1880-1940. Champaign, IL: The University of Illinois Press, 2017.

Chassen-López, Francie. "Distorting the Picture: Gender, Ethnicity, and Desire in a Mexican Telenovela.” Journal of Women's History, 20 (2008): 106-129.

Chestnut, R. Andrew. Devoted to Death: The Skeleton Saint. New York and Oxford: Oxford University Press, 2012.

Chitty, Clyde. Eugenics, Race and Intelligence in Education. London: Continuum Books, 2007.

Chorba, Carrie C. Mexico, From Mestizo to Multicultural: National Identity and Recent Representations of the Conquest. Nashville, TN: Vanderbilt University Press, 2007. Concheiro, Luciano. "Los pueblos indígenas de México eligen a su vocera e irrumpen en el escenario politico.” The New York Times, May 28, 2017. Accessed June 1, 2017, https://www.nytimes.com/es/2017/05/28/los-pueblos-indigenas-de-mexico-eligen-a-suvocera-e-irrumpen-en-el-escenario-politico/?smid=fb-share-es. Cope, Douglas. The Limits of Racial Domination: Plebeian Society in Colonial Mexico City, 1660-1720. Madison, WI: Wisconsin University Press, 1994. 
Cornejo Polar, Antonio. "Mestizaje and Hybridity: The Risks of Metaphors - Notes." In The Latin American Cultural Studies Reader, edited by Alicia Ríos, Abril Trigo and Ana del Sarto, 760-764. Durham and London: Duke University Press, 2004.

Cru, Joseph. "Bilingual Rapping in Yucatán, México: Strategic Choices for Maya Language Legitimation and Revitalisation." International Journal of Bilingual Education and Bilingualism, (2015): 1-16.

Cruz Bárcenas, Arturo. "Yolanda Vargas Dulché, una de las mujeres más leídas en México." La Jornada, November 22, 2012. Accessed January 5, 2018, http://www.jornada.unam.mx/2012/11/22/espectaculos/a08n1esp.

Cvetkovich, Ann. Mixed Feelings: Feminism, Mass Culture, and Victorian

Sensationalism. New Brunswick, NJ: Rutgers University Press, 1992.

Da Costa, Alexandre E. (2016). "The Un(happy) Objects of Affective Community: Mixture, Conviviality and Racial Democracy in Brazil." Cultural Studies, 20 (2016): 2446.

Da Costa, Alexandre E. "Confounding Anti-Racism: Mixture, Racial Democracy, and Post-Racial Politics in Brazil." Critical Sociology, (2014): 1-19.

Davalos, Karen M. Exhibiting Mestizaje: Mexican (American) Museums in the Diaspora. Albuquerque, NM: University of New Mexico Press, 2001.

Davis, Dana-Ain. "Narrating the Mute: Racializing and Racism in a Neoliberal Moment." Souls, 9 (2007): 346-360.

Dawson, Alexander S. Indian and Nation in Revolutionary Mexico. Tucson, AZ: The University of Arizona Press, 2004. 
De la Peña, Guillermo. “A New Mexican Nationalism? Indigenous Rights, Constitutional Reform and the Conflicting Meanings of Multiculturalism." Nations and Nationalism, 12 (2006): 279-302.

Delgadillo, Theresa. Spiritual Mestizaje: Religion, Gender, Race, and Nation in Contemporary Chicana Narrative. Durham and London: Duke University Press, 2011. Demmers, Joelle. "Neoliberal Reforms and Populist Politics.” In Miraculous Metamorphoses: The Neoliberalization of Latin American Populism, edited by Joelle Demmers, Alex E. Fernández Jilberto and Barbara Hogenboom, 150-181. London and New York: Zed Books, 2001.

Dever, Susan. Celluloid Nationalism and Other Melodramas: From Post-Revolutionary Mexico to fin de siglo Mexamérica. New York: State University of New York, 2003. Dillingham, Alan S. Indigenismo and its Discontents: Bilingual Teachers and the Democratic Opening in the Mixteca Alta of Oaxaca, Mexico, 1954-1982. PhD diss. University of Maryland, 2012. Accessed March 15, 2017, http://drum.lib.umd.edu/handle/1903/13633.

Dominguez-Ruvalcabas, Héctor and Patricia Ravelo Blancas. “Obedience without Compliance: The Role of Government, Organized Crime, and NGOs in the System of Impunity that Murders the Women of Ciudad Juárez.” Translated by Sara Koopman. In Terrorizing Women: Feminicide in the Américas, edited by Rosa Linda Fregoso and Cynthia Bejarano, 182-196. Durham and London: Duke University Press, 2010. Doremus, Anne. "Indigenism, Mestizaje, and National Identity in Mexico During the 1940s and the 1950s." Mexican Studies/Estudios Mexicanos, 17 (2001): 375-402. 
Doremus, Anne. Culture, Politics, and National Identity in Mexican Literature and Film, 1929-1952. New York: Peter Lang Publishing, 2001.

Douglas, Susan. "Writing from the Archive: Creating Your Own. In Media History and the Archive, edited by Craig Robertson, 8-20. London and New York: Routledge, 2011. Duggan, Lisa. The Twilight of Equality? Neoliberalism, Cultural Politics, and the Attack on Democracy. Boston, MA: Beacon Press, 2003.

Dulitzky, Ariel E. “A Region in Denial: Racial Discrimination and Racism in Latin America." Translated by David Sperling. In Neither Enemies nor Friends: Latinos, Blacks, Afro-Latinos, edited by Anani Dzidzienyo and Suzanne Oboler, 39-60. New York: Palgrave MacMillan, 2005.

Durán, Javier. "Border Crossings: Images of the Pachuco in Mexican Literature.” Studies in $20^{\text {th }}$ Century Literature, 25 (2001): 140-172.

Durán, Javier. "Nation and Translation: The "Pachuco" in Mexican Popular Culture: Germán Valdés’ Tin Tan." The Journal of the Midwest Modern Language Association, 35 (2002): 41-49.

Durham, Meenakshi G. and Douglas M. Kellner. Media and Cultural Studies: Keyworks. Malden, MA: Blackwell Publishing, 2001.

Durín, Séverine and Natalia Vázquez. "Heroínas-sirvientas: Análisis de las representaciones de trabajadoras domésticas en telenovelas mexicanas" [Heroinesservants: Analysis of Representations of Domestic Workers in Mexican Soap Operas]. Trayectorias, 15 (2013): 20-44.

Dyer, Richard. White. London and New York: Routledge, 1997. 
Earle, Rebecca. The Return of the Native: Indians and Myth-Making in Spanish America, 1810-1930. Durham and London: Duke University Press, 2007.

Editorial Board. "Distorsiones" de Televisa ["Distortions" from Televisa]. Proceso, December 3, 1994. Accessed May 15, 2016, http://www.proceso.com.mx/168486/distorsiones-de-televisa.

Eng, David L. "The Feeling of Kinship: Queer Liberalism and the Racialization of Intimacy.” Durham and London: Duke University Press, 2010.

Estévez, Ariadna. "The Politics of Death and Asylum Discourse: Constituting Migration Biopolitics from the Periphery." Alternatives: Global, Local, Political, 39 (2014): 75-89. Estill, Adriana. "Closing the Telenovela's Borders: Vivo por Elena's Tidy Nation." Chasqui, 29 (2000): 75-87.

Estrada, Carla (Producer). María Isabel (Telenovela). Mexico: Televisa Internacional, 1997-1998.

Esquivel, Edgar, Marco A. González Pérez, Javier Torres Medina and Omar Jiménez. (Eds.) La república informal: El ambulantaje en la ciudad de México [The Informal Republic: Street Vendors in Mexico City]. Mexico: Miguel Ángel Porrúa, 2008. Essed, Philomena. Understanding Everyday Racism: An Interdisciplinary Theory. London: Sage Publications, 1991.

Fabian, Johannes. Time and the Other: How Anthropology Makes its Object ( $2^{\text {nd }}$ ed.). New York: Columbia University Press, 2002.

Fairclough, Norman. Analysing Discourse: Textual Analysis for Social Research. London and New York: Routledge, 2003. 
Fernández, Claudia and Andrew Paxman. El tigre: Emilio Azcárraga y su imperio Televisa. [The Tiger: Emilio Azcárraga and his Televisa Empire]. Mexico: Editorial Grijalbo, 2000.

Fernandez de Castro, Rafa. "Mexico 'Discovers' 1.4 million Black Mexicans - They Just Had to Ask." Fusion, December 15, 2015. Accessed September 15, 2016, http://fusion.net/story/245192/mexico-discovers-1-4-million-black-mexicans-they-justhad-to-ask/.

Fernández L’Hoeste, Héctor. “De estereotipos vecinos: Memín Pinguín como una oportunidad perdida" [Of Nearby Stereotypes: Memín Pinguín as a Lost Opportunity]. Revista Latinoamericana de Estudios Sobre la Historieta, 6 (2006): 144-154.

Foucault, Michel. The Archaeology of Knowledge and the Discourse of Language. Translated by Alan M. Sheridan. New York: Pantheon Books, 1972.

Foucault, Michel. Society Must Be defended. Translated by David Macey. London: Penguin Books, 2004.

Frankenberg, Ruth. White Women, Race Matters: The Social Construction of Whiteness. Minneapolis, MN: University of Minnesota Press, 1993.

Gall, Olivia. "Mexican Long-Living Mestizophilia Versus a Democracy Open to Diversity." Latin American and Caribbean Ethnic Studies, 8 (2013): 280-303. Galton, Francis. "Eugenics." The American Journal of Sociology, 10 (1904). Accessed September 20, 2015, http://www.mugu.com/galton/essays/1900-1911/galton-1904-amjourn-soc-eugenics-scope-aims.htm.

Gamio, Manuel. Forjando patria [Forging a nation] ( $3^{\text {rd }}$ ed.). Argentina: Editorial Porrúa, S.A, 1982. 
García Mora, Carlos and Andrés Medina. La quiebra política de la antropología social en México [The Political Rupture in Social Anthropology in Mexico]. Mexico:

Universidad Nacional Autónoma de México, 1986.

Gaspar de Alba, Alicia. "Malinche's Revenge." In Feminism, Nation and Myth: La Malinche, edited by Rolando Romero and Amanda N. Harris, 44-57. Houston, TX: Arte Público Press, 2005.

Gil Olmos, José. La santa muerte: La virgen de los olvidados [The Holy Death: The Virgin of the Forgotten]. Mexico: Penguin Random House Grupo Editorial México, 2011.

Gillman, Susan. "The Mulatto, Tragic or Triumphant? The Nineteenth-Century American Race Melodrama." In The Culture of Sentiment: Race, Gender, and Sentimentality in $19^{\text {th }}$ Century America, edited by Shirley Samuels, 221-243. New York and Oxford: Oxford University Press, 1992.

Gilroy, Paul. There Ain't No Black in the Union Jack: The Cultural Politics of Race and Nation. Chicago, IL: The University of Chicago Press, 1987.

Gilroy, Paul. After Empire: Melancholia or Convivial Culture? London and New York: Routledge, 2004.

Giraudo, Laura. 'Neither 'Scientific' nor 'Colonialist': The Ambiguous Course of InterAmerican Indigenismo in the 1940s." Translated by Victoria J. Furio. Latin American Perspectives, 39 (2012): 12-32.

Giraudo, Laura and Stephen E. Lewis. "Pan-American Indigenismo (1940-1970): New Approaches to an Ongoing Debate." Latin American Perspectives, 39 (2012): 3-11. 
Glantz, Margo (Ed.) “Las hijas de la Malinche” [Malinche's daughters]. In La Malinche, sus padres y sus hijos. [La Malinche, Her Parents and Her Children], 277-303. Mexico: Taurus, 2001.

Goldberg, David T. The Threat of Race: Reflections on Racial Neoliberalism. Malden, MA: Blackwell Publishing, 2009.

Gómez Romero, Luis. “A Decade of Murder and Grief: Mexico’s Drug War Turns Ten.” The Conversation, December 11, 2016. Accessed March 15, 1027, https://theconversation.com/a-decade-of-murder-and-grief-mexicos-drug-war-turns-ten$\underline{70036}$.

González, Roberto J. "From Indigenismo to Zapatismo: Theory and Practice in Mexican Anthropology." Human Organization, 63 (2004): 141-150.

González Gamio, Angeles. "Manuel Gamio: El amor de un mexicano" [Manuel Gamio: The Love of a Mexican]. La Jornada, August 26, 2012. Accessed September 15, 2015, http://www.jornada.unam.mx/2012/08/26/sem-angeles.html?\#directora.

Gramsci, Antonio. Selections from the Prison Notebooks. Translated by Quintin Hoare and Geoffrey Nowell Smith. New York: International Publishers, 1992.

Gregorius, Arlene. "The Black People from Mexico Who Have Been Erased from History.” BBC, April 11, 2016. Accessed September 15, 2016, http://www.bbc.com/mundo/noticias/2016/04/160410_cultura_mexico_comunidad_negra _discriminacion_wbm

Grenier, Yvon. "Octavio Paz: An Intellectual and His Critics." Mexican Studies/Estudios Mexicanos, 21 (2005): 251-267. 
Grillo, Ioan. El Narco: Inside Mexico's Criminal Insurgency. London and New York: Bloomsbury Press, 2011.

Grovas, Jesús (Producer) \& Juan Bustillo de Oro (Director). (1940). Ahí está el detalle [Here's the point] (Motion Picture). Mexico: Grovas-Oro Films.

Gutiérrez, Natividad. Nationalist Myths and Ethnic Identities: Indigenous Intellectuals and the Mexican State. Lincoln, NE: University of Nebraska Press, 1999.

Gutiérrez Chong, Natividad. "Symbolic Violence and Sexualities in the Myth Making of Mexican National Identity.” Ethnic and Racial Studies, 31 (2008): 524-542.

Hale, Charles R. "Does Multiculturalism Menace? Governance, Cultural Rights and the Politics of Identity in Guatemala." Journal of Latin American Studies, 38 (2002): 485524.

Hale, Charles R. "Rethinking Indigenous Politics in the Era of the 'Indio Permitido."” NACLA, Report on the Americas, (2004): 16-37.

Hale, Charles R. Más que un indio: Racial Ambivalence and Neoliberal Multiculturalism in Guatemala. Santa Fe, NM: School of American Research Press, 2006.

Hall, Stuart. (Ed.) The spectacle of the "other." In Representation: Cultural representations and signifying practices, 223-290. London: Sage Publications, 1997. Hall, Stuart. "Foucault: Power, Knowledge and Discourse." In Discourse Theory and Practice: A Reader, edited by Margaret Wetherell, Stephanie Taylor and Simeon J. Yates, 198-209. London: Sage Publications, 2001. Hall, Stuart. 'The spectacle of the 'other.' In Discourse Theory and Practice: A Reader, edited by Margaret Wetherell, Stephanie Taylor and Simeon J. Yates, 324-344. London: Sage Publications, 2001. 
Haraway, Donna. "Situated Knowledges: The Science Question in Feminism and the Privilege of Partial Perspective.” Feminist Studies, 14 (1988): 575-599.

Herman, Ellen. The Romance of American Psychology: Political Culture in the Age of Experts. Berkeley and Los Angeles: University of California Press, 1995.

Hernández, Tanya K. Racial Subordination in Latin America: The Role of the State, Customary Law, and the New Civil Rights Response. Cambridge, UK: Cambridge University Press, 2013.

Hernández Castillo, Rosalva A. Histories and Stories from Chiapas: Border Identities in Southern Mexico. Austin, TX: University of Texas Press, 2001.

Herrera-Sobek, María. "In Search of La Malinche: Pictorial Representations of a MythoHistorical Figure." In Feminism, Nation and Myth: La Malinche, edited by Rolando Romero and Amanda N. Harris, 112-133. Houston, TX: Arte Público Press, 2005.

Hershfield, Joanne. "Race and Ethnicity in the Classical Cinema." In Mexico's Cinema: A Century of Film and Filmmakers, edited by Joanne Hershfield and David Maciel, 81100. Oxford, UK: SR Books, 1999.

Hindley, Jane. "Towards a Pluricultural Nation: The Limits of Indigenismo and Article 4.” In Dismantling the Mexican State? Edited by Rob Aitken, Nikki Craske, Gareth A. Jones and David E. Stansfield, 225-243. London, UK: MacMillan Press Ltd., 1996.

Hooker, Juliet. "Indigenous Inclusion/ Black Exclusion: Race, Ethnicity and Multicultural Citizenship in Latin America." Journal of Latin American Studies, 37 (2005): p.1-26.

Hooker, Juliet. “Hybrid Subjectivities, Latin American Mestizaje, and Latino Political Thought on Race." Politics, Groups, and Identities, (2014): 1-14. 
hooks, bell. Yearning: Race, Gender, and Cultural Politics. Boston, MA: South End Press, 1990.

Hunter, Margaret L. “'If You're Light You're Alright:' Light Skin Color as Social Capital for Women of Color.” Gender and Society, 16 (2002): 175-193.

Hunter, Margaret L. Race, Gender, and the Politics of Skin Tone. London and New York: Routledge, 2005.

Iliff, Laurence and Lennox Samuels. "President Vicente Fox’s Comment Reflects Mexican Attitude on Race.” The Seattle Times, May 18, 2005. Accessed May 30, 2017, http://www.seattletimes.com/nation-world/president-vicente-foxs-comment-reflectsmexican-attitude-on-race/.

Jiménez del Val, Nasheli. "Pinturas de Casta: Mexican Caste Paintings, a Foucauldian Reading." New Readings, 10 (2009): 1-17.

Jiménez Román, Miriam. "Looking at that Middle Ground: Racial Mixing as Panacea?" In A Companion to Latinalo Studies, edited by Juan Flores and Renato Rosaldo, 325-336. Malden, MA: Blackwell Publishing, 2007.

Joseph, Gilbert M., Anne Rubenstein and Eric Zolov. (Eds.) “Assembling the Fragments: Writing a Cultural History of Mexico Since 1940.” In Fragments of a Golden Age: The Politics of Culture in Mexico Since 1940, 3-22. Durham and London: Duke University Press.

Joseph, Gilbert M. and Timothy J. Henderson. (Eds.) The Mexico Reader: History, Culture, Politics. Durham and London: Duke University Press, 2002. Jung, Courtney. "The Politics of Indigenous Identity: Neo-Liberalism, Cultural Rights, and the Mexican Zapatistas." Social Research, 70 (2003): 433-462. 
Kaplan, Ann. Women and Film: Both Sides of the Camera. London and New York:

Routledge, 1983.

Kaplan, Ann. Looking for the Other: Feminism, Film and the Imperial Gaze. London and New York: Routledge, 1997.

Kaplan, Caren. Questions of Travel: Postmodern Discourses of Displacement. Durham and London: Duke University Press, 1996.

Katzew, Ilona. Casta Painting: Images of Race in Eighteenth-Century Mexico. New Haven, CT: Yale University Press, 2004.

Kellogg, Susan. "Depicting Mestizaje: Gendered Images of Ethnorace in Colonial Mexican Texts." Journal of Women's History, 12 (2000): 69-92.

King, Linda. Roots of Identity: Language and Literacy in Mexico. Palo Alto, CA: Stanford University Press, 1994.

Klaufus, Christien. "Taking up Residency: Spatial Reconfigurations and the Struggle to Belong in Urban Latin America." In Housing and Belonging in Latin America, edited by Christien Klaufus and Arij Ouweneel, 1-20. New York and Oxford: Berghahn Books, 2015.

Kline, Wendy. Building a Better Race: Gender, Sexuality, and Eugenics from the Turn of the Century to the Baby Boom. Berkeley and Los Angeles: University of California Press, 2001.

Kluchin, Rebecca M. Fit to be Tied: Sterilization and Reproductive Rights in America, 1950-1980. New Brunswick, NJ: Rutgers University Press, 2009. 
Knight, Alan. "Racism, Revolution, and Indigenismo: Mexico, 1910-1940.” In The Idea of Race in Latin America, 1870-1940, edited by Richard Graham, 71-113. Austin, TX: University of Texas Press, 1990.

Knight, Alan. "Populism and Neo-Populism in Latin America, Especially Mexico." Journal of Latin American Studies, 30 (1998): 223-248.

Knoll, Andalusia. “The Mexico City Barrio Giuliani Couldn’t Conquer.” Vice, July 3, 2013. Accessed March 15, 2015, https://www.vice.com/en_us/article/tepito-is-mexicocitys-last-untamed-barrio.

Krauze, Enrique. Mexico: Biography of Power. Translated by Hank Heifetz. New York: Harper Collins Publishers, 1997.

Krauze, Enrique. “The Pride in Memín Pinguín.” The Washington Post, July 12, 2005. Accessed May 30, 2017, http://www.washingtonpost.com/wpdyn/content/article/2005/07/11/AR2005071101413.html. Krauze, Enrique. "Mexico's Strengths Still Shine Through the Gloom.” Bloomberg View, December 29, 2011. Accessed January 15, 2015, http://www.bloombergview.com/articles/2011-12-30/mexico-s-strengths-still-peakthrough-gloom-commentary-by-enrique-krauze.

Kubal, Timothy. Cultural Movements and Collective Memory: Christopher Columbus and the Rewriting of the National Origin Myth. New York: Palgrave Macmillan, 2008. Lakhani, Nina. "Mexico Tortures Migrants - And Citizens - in Effort to Slow Central American Surge.” The Guardian, April 4, 2016. Accessed March 15, 2017, https://www.theguardian.com/world/2016/apr/04/mexico-torture-migrants-citizenscentral-america. 
Larrain, Jorge. Identity and Modernity in Latin America. Cambridge, UK: Polity Press, 2000.

Leaman, David. "Changing Faces of Populism in Latin America: Masks, Makeovers, and Enduring Features." Latin American Research Review, 39 (2004): 312-326.

Lentin, Alana and Gavan Titley. The Crises of Multiculturalism: Racism in a Neoliberal Age. London and New York: Zed Books, 2011.

L’Estoile, Benoit, Federico Neiburg and Lygia M. Sigaud. (Eds.) "Introduction: Anthropology and the Government of 'Natives,' a Comparative Approach.” In Empires, Nations, and Natives: Anthropology and State-Making, 1-29. Durham and London: Duke University Press, 2005.

Levine-Rasky, Cynthia (Ed.). Working Through Whiteness: International Perspectives. New York: State University of New York Press, 2002.

Lewis, Stephen E. “The Nation, Education, and the 'Indian Problem' in Mexico, 19201940." In The Eagle and the Virgin: Nation and Cultural Revolution in Mexico, 19201940, edited by Mary K. Vaughan and Stephen E. Lewis, 176-195. Durham and London: Duke University Press, 2006.

Lewis, Stephen E. “Indigenista Dreams Meet Sober Realities: The Slow Demise of Federal Indian Policy in Chiapas, Mexico, 1951-1970, Latin American Perspectives, 39 (2012): 63-79.

Linthicum, Kate. "More Central Americans are Giving Up on the U.S. and Looking Instead to a Mexican Dream.” Los Angeles Times, December 1, 2016. Accessed May 30, 2017, http://www.latimes.com/sdhoy-more-central-americans-are-giving-up-on-the-u-sand-looking-instead-to-a-mexican-dream-20161203-story.html. 
Littler, Jo. “Meritocracy as Plutocracy: the Marketising of ‘Equality’ Under Neoliberalism.” New Formations, 80 (2012): 52-72.

Lomnitz, Claudio. Exits from the Labyrinth: Culture and Ideology in the Mexican National Space. Berkeley and Los Angeles: University of California Press, 1992. Lomnitz, Claudio. "Fissures in Contemporary Mexican Nationalism.” Public Culture, 9 (1996): 55-68.

Lomnitz, Claudio. Deep Mexico, Silent Mexico: An Anthropology of Nationalism. Minneapolis, MN: University of Minnesota Press, 2001.

Lomnitz, Claudio. "Bordering on Anthropology: Dialectics of a National Tradition in Mexico." In Empires, Nations, and Natives: Anthropology and State-Making, edited by Benoit L'Estoile, Federico Neiburg and Lygia M. Sigaud, 167-196. Durham and London: Duke University Press, 2005.

Lomnitz, Claudio. "The Origins of our Supposed Homogeneity: A Brief Archeology of National Unity in Mexico.” Prismas, 14 (2010): 17-36.

Lopez, Ana M. "Tears and Desire: Women and Melodrama in the 'Old' Mexican Cinema." In Mediating Two Worlds: Cinematic Encounters in the Americas, edited by John King, Ana M. Lopez and Manuel Alvarado, 147-163. London: BFI Publishing, 1993.

Lopez, Ana M. "Our Welcomed Guests: Telenovelas in Latin America." In To Be Continued...Soap Operas Around the World, edited by Robert Allen, 256-275. London and New York: Routledge, 1995.

López, Rick. "The India Bonita Contest of 1921 and the Ethnicization of Mexican National Culture.” Hispanic American Historical Review, 82 (2002): 291-328. 
Macías-González, Víctor M. and Anne Rubenstein. Masculinity and Sexuality in Modern Mexico. Albuquerque, NM: University of New Mexico Press, 2012.

Malcomson, Hettie. “La configuración racial del danzón: Los imaginarios raciales del puerto de Veracruz" [The Racial Configuration of Danzón: The Racial Imaginaries of the Port of Veracruz]. In Mestizaje, diferencia y nación: Lo 'negro' en Américal central y el Caribe [Mestizaje, Difference and Nation: "Blackness" in Central America and the Caribbean], edited by Elisabeth Cunin, 267-298. Mexico: Instituto Nacional de Antropología e Historia, 2010.

Mallon, Florencia E. Peasant and Nation: The Making of Postcolonial Mexico and Peru. Los Angeles and Berkeley: University of California Press, 1995.

Mallon, Florencia E. "Constructing Mestizaje in Latin America: Authenticity, Marginality, and Gender in the Claiming of Ethnic Identities." Journal of Latin American Anthropology, 2 (1996): 170-181.

Mani, Lata. "Multiple Mediations: Feminist Scholarship in the Age of Multinational Reception.” Feminist Review, 35 (1990): 24-41.

Manzo, Kathryn A. Creating Boundaries: The Politics of Race and Nation. Boulder, CO: Lynne Rienner Publishers, 1998.

Marroquín, Alejandro D. Balance del indigenismo [Balancing Indigenismo]. Mexico: Instituto Indigenista Interamericano, 1977. Martínez Andrade, Luis. Religion Without Redemption: Social Contradictions and Awakened Dreams in Latin America. London: Pluto Press, 2015. Martínez Casas, Regina, Emíko Saldívar, René D. Flores and Christina A. Sue. “The Different Faces of Mestizaje: Ethnicity and Race in Mexico.” In Pigmentocracies: 
Ethnicity, Race and Color in Latin America, edited by Edward Telles, 36-80. Chapel Hill, NC: The University of North Carolina Press, 2014.

Martínez de Alva, Ernesto. "La vida del campo" [Life on the Countryside]. In $E l$ Maestro, 1 (1921): 77-81.

Martínez Novo, Carmen. Who Defines Indigenous? Identities, Development, Intellectuals, and the State in Northern Mexico. New Brunswick, NJ: Rutgers University Press, 2006.

Martínez Solares, Gilberto (Director). El rey del barrio [The King of the Neighborhood] (Motion Picture). Mexico: AS Films S.A, 1949.

Mbembe, Achilles. "Necropolitics." Translated by Libby Meintjes. Public Culture, 15 (2003): p.11-40.

McClintock, Anne. Imperial Leather: Race, Gender and Sexuality in the Colonial Contest. New York and London: Routledge, 1995.

McKee Irwin, Robert. "El recurso literario latinoamericano en su contexto globalizado," Cuadernos de literatura, 17 (2013): 65-81.

Medina, Rubén. "El mestizaje a través de la frontera: Vasconcelos y Anzaldúa." Mexican Studies/ Estudios Mexicanos, 25 (1): 101-123.

Melamed, Jodi. “The Spirit of Neoliberalism: From Racial Liberalism to Neoliberal Multiculturalism.” Social Text, 89 (2006): 1-24.

Meri Jones, Jennifer A. “'Mexicans Will Take the Jobs that Even Blacks Won't Do': An Analysis of Blackness, Regionalism and Invisibility in Contemporary Mexico." Ethnic and Racial Studies, 36 (2013): 1564-1581. 
Merish, Lori. Sentimental Materialism: Gender, Commodity Culture, and NineteenthCentury American Literature. Durham and London: Duke University Press, 2000. Messinger Cypess, Sandra. La Malinche in Mexican Literature: From History to Myth. Austin, TX: University of Texas Press, 1991.

Messinger Cypess, Sandra. “'Mother' Malinche and Allegories of Gender, Ethnicity and National Identity in Mexico.” In Feminism, Nation and Myth: La Malinche, edited by Rolando Romero and Amanda N. Harris, 14-27. Houston, TX: Arte Público, 2005. Mignolo, Walter D. The Idea of Latin America. Malden, MA: Blackwell Publishing, 2005.

Milenio Digital. "Cuenta 'Crónica de castas' una historia de la vida real [“Crónica de castas” Tells a Real Life Story]. Milenio, March 31, 2014. Accessed May 15, 2015, http://www.milenio.com/hey/television/Cronica_de_castas_0_272373058.html.

Miller, Marjorie and Juanita Darling. "El tigre: Broadcasting Baron Emilio Azcárraga Monopolizes Mexican Culture and Controls the News. Now He's Stalking the US.” Los Angeles Times, November 10, 1991. Accessed February 20, 2014, http://articles.latimes.com/1991-11-10/magazine/tm-2187_1_emilio-azcarraga. Miller, Marilyn G. Rise and Fall of the Cosmic Race: The Cult of Mestizaje in Latin America. Austin, TX: University of Texas Press, 2004.

Miller, Michael N. Red, White and Green: The Maturing of Mexicanidad, 1940-1946. El Paso, TX: Texas Western Press, 1999. Miller, Nicola. In the Shadow of the State: Intellectuals and the Quest for National Identity in Twentieth-Century Spanish America. London and New York: Verso, 1999. 
Miller, Nicola. "The Historiography of Nationalism and National Identity in Latin America." Nations and Nationalism, 12 (2006): 201-221.

Mobwa Mobwa N'Djoli, Jean-Philibert. “The Need to Recognize Afro-Mexicans as an Ethnic Group.” In Black Mexico: Race and Society from Colonial to Modern Times, edited by Matthew Restall and Ben Vinson III, 224-231. Albuquerque, NM: University of New Mexico Press, 2009.

Molina Enríquez, Andrés. Los grandes problemas nacionales [The Great National

Problems]. Mexico: Instituto Nacional de la Juventud Mexicana, 1964.

Monsiváis, Carlos. Mexican Postcards. Translated by John Kraniauskas. London and New York: Verso, 1997.

Montezemolo, Fiamma. “(Conversation with) Néstor García Canclini, on how Tijuana Ceased to Be the Laboratory of Postmodernity." In Tijuana Dreaming: Life and Art at the Global Border, edited by Josh Kun and Fiamma Montezemolo, 94-116. Durham and London: Duke University Press, 2012.

Mora, Carl J. Mexican Cinema: Reflections of a Society, 1896-2004. Jefferson, NC: MacFarland \& Company, Inc. Publishers, 2005.

Mora, Mariana. “Ayotzinapa and the Criminalization of Racialized Poverty in La Montaña, Guerrero, Mexico.” Political and Legal Anthropology Review, 40 (2017): 6785.

Moraga, Cherríe. Loving in the War Years: Lo que nunca pasó por sus labios. Brooklyn, NY: South End Press, 1983. 
Moraga, Cherríe. Queer Aztlán: The Re-Formation of Chicano Tribe. Accessed September 15, 2016, https://thequeerartofutopia.files.wordpress.com/2012/04/moraga1.pdf. Moran, Joe. Interdisciplinarity. London and New York: Routledge, 2002. Moreno Figueroa, Mónica. “'Linda Morenita': Skin Colour, Beauty and the Politics of Mestizaje in Mexico." In Cultures of Colour: Visual, Material, Textual, edited by Chris Horrocks, 167-180. New York and Oxford: Berghahn Books, 2012. Moreno Figueroa, Mónica. "Displaced Looks: The Lived Experience of Beauty and Racism.” Feminist Theory, 14 (2013): 137-151. Moreno Figueroa, Mónica \& Saldívar, Emíko. “'We Are Not Racists, We Are Mexicans:’ Privilege, Nationalism and Post-Race Ideology in Mexico." Critical Sociology, (2015): 119.

Morris, Stephen D. "Between Neo-Liberalism and Neo-Indigenismo: Reconstructing National Identity in Mexico.” National Identities, 3 (2001): 239-255. Mraz, John. Looking for Mexico: Modern Visual Culture and National Identity. Durham and London: Duke University Press, 2009. Mulvey, Laura. "Visual Pleasure and Narrative Cinema." In Film Theory and Criticism: Introductory Readings, edited by Leo Braudy and Marshall Cohen, 833-844. New York and Oxford: Oxford University Press, 1999.

Murphy, Patrick. "Television and Cultural Politics in Mexico: Some Notes on Televisa, the State, and Transnational Culture." Howard Journal of Communications, 6 (1995): 250-261. 
Nahmad Sittón, Salomón. "Mexico: Anthropology and the Nation-State." In A

Companion to Latin American Anthropology, edited by Deborah Poole, 128-149. Malden, MA: Blackwell Publishing, 2008.

Nanni, Giordano. The Colonisation of Time: Ritual, Routine and Resistance in the British Empire. Manchester, UK: Manchester University Press, 2012.

Nariman, Heidi N. Soap Operas for Social Change: Toward a Methodology for

Entertainment-Education Television. Westport, CT: Praeger Publishers, 1993.

Nayak, Anoop. “Critical Whiteness Studies.” Sociology Compass, 27 (2007): 741.

Neale, Steve. "Melodrama and Tears." Screen, 27 (1986): 6-23.

Nogueira Joyce, Samantha. Brazilian Telenovelas and the Myth of Racial Democracy.

Lanham, MD: Lexington Books, 2012.

Nutini, Hugo. "Class and Ethnicity in Mexico: Somatic and Racial Considerations."

Ethnology, 36 (1997): 227-238.

Olcott, Jocelyn. "The Politics of Opportunity: Mexican Populism under Lázaro Cárdenas and Luis Echeverría." In Gender and Populism in Latin America: Passionate Politics, edited by Karen Kampwirth, 25-46. University Park, PA: The Pennsylvania State University Press, 2010.

O'Malley, Ilene V. The Myth of the Revolution: Hero Cults and the Institutionalization of the Mexican State, 1920-1940. Westport, CT: Greenwood Press, Inc., 1986.

Orgler, Hertha. Alfred Adler: The Man and His Work. New York: Liveright Publishing Corporation, 1963.

Osorno, Diego E. La guerra de los Zetas: Viaje por la frontera de la necropolítica [The Zetas War: Traveling on the Necropolitical Border]. Mexico: Grijalbo, 2012. 
Otero, Gerardo. (Ed.) "Neoliberal Reform and Politics in Mexico: An Overview. In Neoliberalism Revisited: Economic Restructuring and Mexico's Political Future, 1-25. Boulder, CO: Westview Press, 1996.

O’Toole, Gavin. The Reinvention of Mexico: National Ideology in a Neoliberal Era. Liverpool, UK: Liverpool University Press, 2010.

Overmyer-Velázquez, Rebecca. Folkloric Poverty: Neoliberal Multiculturalism in Mexico. University Park, PA: The Pennsylvania State University Press, 2010.

Pacheco de Oliveira, João. “The Anthropologist as Expert: Brazilian Ethnology Between Indianism and Indigenism." In Empires, Nations, and Natives: Anthropology and StateMaking, edited by Benoit L'Estoile Federico, Neiburg and Lygia M. Sigaud, 223-247. Durham and London: Duke University, 2005.

Packer, Jeremy. "What is an Archive? An Apparatus Model for Communications and Media History." In Media History and the Archive, edited by Craig Robertson, 91-107. London and New York: Routledge, 2011.

Palapa, Fabiola, Ericka Montaño and Mónica Mateos. (Eds.) “Memín Pinguín ‘no es el icono del racismo en México"” [Memín Pinguín is "Not the Popular Icon of Racism in Mexico"]. La Jornada, accessed May 30, 2017, http://www.jornada.unam.mx/2005/07/01/index.php?section=cultura\&article=a04n1 cul. Parry, Manon. Broadcasting Birth Control: Mass Media and Family Planning. New Brunswick, NJ: Rutgers University Press, 2013. Paz, Octavio. El laberinto de la soledad [The Labyrinth of Solitude]. Mexico: Fondo de Cultura Económica, 1950. 
Peña Delgado, Grace. Making the Chinese Mexican: Global Migration, Localism, and Exclusion in the U.S.-Mexico Borderlands. Palo Alto, CA: Stanford University Press, 2012.

Pérez Torres, Rafael. Mestizaje: Critical Uses of Race in Chicano Culture. Minneapolis, MN: University of Minnesota Press, 2006.

Pérez Vejo, Tomás. "La extranjería en la construcción nacional mexicana" [Otherness in the Construction of Mexican Nationalism]. In Nación y extranjería: La exclusión racial en las políticas migratorias de Argentina, Brasil, Cuba y México [Nation and Otherness: Racial Exclusion in Immigration Policies in Argentina, Brazil, Cuba and Mexico], edited by Pablo Yankelevich. Mexico: Universidad Nacional Autónoma de México, 2010.

Pilcher, Jeffrey M. Cantinflas and the Chaos of Modernity. Wilmington, DE: Scholarly Resources Inc., 2001.

Pimstein, Valentín (Executive Producer). Simplemente María (Telenovela). Mexico: Televisa Internacional, 1989.

Ponti, Martín. "Globo vs. Sistema Brasileiro de Televisao (SBT): Paradigms of Consumption and Representation on Brazilian Telenovelas." In Soap Operas and Telenovelas in the Digital Age: Global Industries and New Audiences, edited by Diana I Rios and Mari Castañeda, 219-236. New York: Peter Lang Publishing, 2011. Poovey, Mary. Making a Social Body: British Cultural Formation, 1830-1864. Chicago, IL: The University of Chicago Press, 1995.

Porto, Mauro. "Telenovelas and Representations of National Identity in Brazil." Media, Culture and Society, 33 (2011): 53-69. 
Pratt, Mary L. Imperial Eyes: Travel Writing and Transculturation. (2 $2^{\text {nd }}$ ed.). London and New York: Routledge, 2008.

Radcliffe, Sarah and Sallie Westwood. Remaking the Nation: Place, Identity and Politics in Latin America. London and New York: Routledge, 1996.

Ramírez Berg, Charles. Cinema of Solitude: A Critical Study of Mexican Film, 19671983. Austin, TX: University of Texas Press, 1992.

Ramos, Alcida Rita. “The Hyperreal Indian,” Critique of Anthropology, 14 (1994): 153 171.

Ramos Pedrueza, Rafael. "Historia mexicana” [Mexican History]. In El Maestro, 2 (1921): 123-130.

Ramos, Samuel. El perfil del hombre y la cultura en México [Profile of Man and Culture in Mexico]. (2 ${ }^{\text {nd }}$ ed.) Mexico: Editorial Pedro Robredo, 1938.

Reguillo, Rossana. "La narcomáquina y el trabajo de la violencia: Apuntes para su decodificación" [The Narco-Machine and the Work of Violence: Notes on How to Decode Them]. E-misférica, 8 (2011). Accessed March 15, 2017, http://hemisphericinstitute.org/hemi/es/e-misferica-82/reguillo. Rénique, Gerardo. “Race, Region, and Nation: Sonora’s Anti-Chinese Racism and Mexico's Postrevolutionary Nationalism, 1920s-1930s." In Race and Nation in Latin America, edited by Nancy P. Appelbaum, Anne S. Macpherson and Karin A. Rosemblatt, 211-236. Chapel Hill, NC: The University of North Carolina Press, 2003.

Reyes Ruiz, Claudia. "Historia y actualidad del culto a la Santa Muerte" [History and the Contemporary Cult to the Holy Death]. El cotidiano, 169 (2011): 51-57. 
Richards, Graham. “'Race,' Racism and Psychology: Towards a Reflexive History. London and New York: Routledge, 1987.

Roberts, David and Minelle Mahtani. "Neoliberalizing Race, Racing Neoliberalism:

Placing 'Race' in Neoliberal Discourses.” Antipode, 42 (2010): 248-257.

Robertson, Craig (Ed.) "Introduction: Thinking About Archives, Writing About History."

In Media History and the Archive, 1-7. London and New York: Routledge: 2011.

Rodríguez Cadena, María de los Angeles. "Contemporary Hi(stories) of Mexico:

Fictional Re-Creation of Collective Past on Television." Film \& History, 34 (2004): 49-

55.

Romero, Rolando J. "Foundational Motherhood: Malinche/Guadalupe in Contemporary Mexican and Chicana/Chicano Culture.” In Feminism, Nation and Myth: La Malinche, edited by Rolando Romero and Amanda N. Harris, 28-43. Houston, TX: Arte Público Press, 2005.

Romo, Tere. "La Malinche as Metaphor." In Feminism, Nation and Myth: La Malinche, edited by Rolando Romero and Amanda N. Harris, 139-152. Houston, TX: Arte Público Press, 2005.

Rottenberg, Catherine. "The Rise of Neoliberal feminism.” Cultural Studies, (2013): 120.

Rowe, William and Vivian Schelling. Memory and Modernity: Popular Culture in Latin America. London and New York: Verso, 1991.

Saade Granados, Marta. “QQuiénes deben procrear? Los medico eugenistas bajo el signo social (México, 1931-1940)" [Who Must Procreate? Eugenicists Under the Social Strain \{Mexico, 1931-1940\}]. Cuicuilco Nueva Epoca, 11 (2004): 1-36. 
Saade Granados, Marta. "Una raza prohibida: afroestadounidenses en México" [A Forbidden Race: African Americans in Mexico]. In Nación y extranjería: La exclusión racial en las políticas migratorias de Argentina, Brasil, Cuba y México [Nation and Otherness: Racial Exclusion in Immigration Policies in Argentina, Brazil, Cuba and Mexico], edited by Pablo Yankelevich, 231-276. Mexico: Universidad Nacional Autónoma de México, 2010.

Sabido, Miguel. "The Origins of Entertainment-Education.” In Entertainment-Education and Social Change: History, Research, and Practice, edited by Arvind Singhal, Michael J. Cody, Everett Rogers and Miguel Sabido, 61-74. Mahwah, NJ: Lawrence Erlbaum Associates, 2004.

Sadlier, Darlene J. (Ed.) "Introduction: A Short History of Film Melodrama in Latin America." In Latin American Melodrama: Passion, Pathos, and Entertainment, 1-18. Urbana and Chicago, IL: University of Illinois Press, 2008.

Said, Edward. Orientalism. (3rd ed.) London: Penguin Books, 2003.

Saldívar, Emiko. Prácticas cotidianas del estado: Una etnografía del indigenismo. Mexico: Universidad Iberoamericana, 2008.

Saldívar, Emiko. "Everyday Practices of Indigenismo: An Ethnography of Anthropology and the State in Mexico." The Journal of Latin American and Caribbean Anthropology, 16 (2011): 67-89.

Salinas de Gortari, Carlos. "Reformando al estado" [Reforming the State]. Nexos, April 1, 1990. Accessed March 15, 2015, http://www.nexos.com.mx/?p=5788. 
Sanchez, Magaly. "Insecurity and Violence as a New Power Relation in Latin America." The Annals of the American Academy of Political and Social Science, 606 (2006): 178195.

Sánchez Prado, Ignacio M. "Claiming Liberalism: Enrique Krauze, Vuelta, Letras Libres, and the Reconfigurations of the Mexican Intellectual Class." Mexican Studies/Estudios Mexicanos, 26 (2010): 47-78.

Sánchez Prado, Ignacio M. Screening Neoliberalism: Transforming Mexican Cinema, 1988-2012. Nashville, TN: Vanderbilt University Press, 2014.

Sandoval, Chela. "Mestizaje as Method." In Living Chicana Theory, edited by Carla M. Trujillo, 352-370. San Antonio, TX: Third Woman Press, 1998.

Sanjinés, Javier. Mestizaje Upside-Down: Aesthetic Politics in Modern Bolivia.

Pittsburgh, PA: University of Pittsburgh Press, 2004.

Schaefer, Claudia. Danger Zones: Homosexuality, National Identity, and Mexican Culture. Tucson, AZ: The University of Arizona Press, 1996.

Schell, Patience A. "Eugenics Policy and Practice in Cuba, Puerto Rico, and Mexico." In

The Oxford Handbook of the History of Eugenics, edited by Alison Bashford and Philippa Levine, 477-492. New York and Oxford: Oxford University Press, 2010.

Schwaller, Robert C. “"Mulata, hija de negro [e] india:” Afro-Indigenous Mulatos in Early Colonial Mexico.” Journal of Social History, 44 (2011): 889-914.

Schelling, Vivian (Ed.) "Introduction: Reflections on the Experience of Modernity in Latin America." In Through the Kaleidoscope: The Experience of Modernity in Latin America, 1-34. London and New York: Verso, 2000. 
Schelling, Vivian. "Popular Culture in Latin America." In Modern Latin American Culture, edited by John King, 171-203. Cambridge, UK: Cambridge University Press, 2004.

Schmidt, Henry C. The Roots of Lo Mexicano: Self and Society in Mexican Thought, 1900-1934. College Station, TX: Texas A\&M University Press, 1978.

Schmidt Camacho, Alicia. "Ciudadana X: Gender Violence and the Denationalization of Women's Right in Ciudad Juárez, Mexico.” In Terrorizing Women: Feminicide in the Américas, edited by Rosa Linda Fregoso and Cynthia Bejarano, 275-289. Durham and London: Duke University Press, 2010.

Sexton, Jared. "The Consequence of Race Mixture: Racialised Barriers and the Politics of Desire." Journal for the Study of Race, Nation and Culture, 9 (2010): 241-275.

Sheridan, Guillermo. México en 1932: La polémica nacionalista [Mexico in 1932: The Nationalist Controversy]. Mexico: Fondo de Cultura Económica, 1999.

Shohat, Ella. "Imaging Terra Incognita: The Disciplinary Gaze of Empire." Public Culture, 3 (1991): p.41-70.

Shohat, Ella and Robert Stam. Unthinking Eurocentrism: Multiculturalism and the Media. New York and London: Routledge, 1994.

Sieder, Rachel (Ed.) "Recognising Indigenous Law and the Politics of State Formation in Mesoamerica. In Multiculturalism in Latin America: Indigenous Rights, Diversity and Democracy, 184-207. New York: Palgrave Macmillan, 2002.

Sinclair, John. Latin American Television: A Global View. New York and Oxford:

Oxford University Press, 1999. 
Singer, Ben. Melodrama and Modernity: Early Sensational Cinema and its Contexts. New York: Columbia University Press, 2001.

Singhal, Arvind, Rafael Obregón and Everett Rogers. "Reconstructing the Story of Simplemente María, the Most Popular Telenovela in Latin America of All Time." Gazette, 54 (1994): 1-15.

Singhal, Arvind and Everett Rogers. Entertainment-Education: A Communication

Strategy for Social Change. Mahwah, NJ: Lawrence Erlbaum Associates Publishers, 1999.

Singhal, Arvind and Everett Rogers, E.M. "A Theoretical Agenda for EntertainmentEducation." Communication Theory, 2 (2002): 117-135.

Sluga, Glenda. The Nation, Psychology, and International Politics, 1870-1919. New York: Palgrave Macmillan, 2006.

Smith, Anthony D. Myths and Memories of the Nation. New York and Oxford: Oxford University Press, 1999.

Smith, Jeremy. "Outside and Against the Quincentenary: Modern Indigenous

Representations at the Time of the Columbus Celebrations," Atlantic Studies, 6 (2009): 63-80.

Snead, James. 'Spectatorship and Capture in 'King Kong:' The Guilty Look.” In Representing Blackness: Issues in Film and Video, edited by Valerie Smith. New Brunswick, NJ: Rutgers University Press, 1997.

Solano, Andrés (Producer) and Daniel Giménez Cacho (Director). Crónica de castas [Chronicles of Caste] (TV series). Mexico: Canal Once, 2014. 
Sommer, Doris. Foundational Fictions: The National Romances of Latin America.

Berkeley and Los Angeles: University of California Press, 1991.

Sotomayor, Carlos and Ernesto Alonso (Producers). El vuelo del águila [The Flight of the

Eagle] (Telenovela). Mexico: Televisa Internacional, 1994-1995.

Souza Lima, Antonio C. "Indigenism in Brazil: The International Migration of State

Policies." In Empires, Nations, and Natives: Anthropology and State-Making, edited by

Benoit L'Estoile, Federico Neiburg and Lygia M. Sigaud, 197-222. Durham and London:

Duke University Press, 2005.

Stavans, Ilan. José Vasconcelos: The Prophet of Race. New Brunswick, NJ: Rutgers

University Press, 2001.

Stepan, Nancy L. The Hour of Eugenics: Race, Gender, and Nation in Latin America.

Ithaca, NY: Cornell University Press, 1991.

Stern, Alexandra M. "Responsible Mothers and Normal Children: Eugenics, Nationalism, and Welfare in Post-Revolutionary Mexico, 1920-1940." Journal of Historical Sociology, 12 (1999): 369-397.

Stern, Alexandra M. Mestizophilia, Biotypology, and Eugenics in Post-Revolutionary Mexico: Towards a History of Science and the State, 1920-1960. Chicago, IL: Center for Latin American Studies, The University of Chicago, 1999.

Stern, Alexandra M. "From Mestizophilia to Biotypology: Racialization and Science in Mexico, 1920-1960." In Race and Nation in Modern Latin America, edited by Nancy P. Appelbaum, Anne S. Macpherson and Karin A. Rosemblatt, 187-210. Chapel Hill, NC: The University of North Carolina Press, 2003. 
Stern, Alexandra M. Eugenic Nation: Faults and Frontiers of Better Breeding in Modern America. Berkeley and Los Angeles, CA: University of California Press, 2005.

Stern, Alexandra M. “'The Hour of Eugenics' in Veracruz, Mexico: Radical Politics, Public Health, and Latin America's Only Sterilization Law.” Hispanic American Historical Review, 91 (2011): 431-443.

Stutzman, Ronald. "El Mestizaje: An All-Inclusive Ideology of Exclusion.” In Cultural Transformations and Ethnicity in Modern Ecuador, edited by Norman E. Whitten, 45-94.

Urbana, IL: University of Illinois Press, 1981.

Suárez, Laura. "La influencia de la sociedad eugénica mexicana en la educación y en la medicina social" [The Mexican Eugenics Society's Influence on Education and Social Medicine]. Asclepio, 2 (1999): 51-84.

Sue, Christina A. "The Dynamics of Color: Mestizaje, Racism, and Blackness in Veracruz, Mexico." In Shades of Difference: Why Skin Color Matters, edited by Evelyn Nakano Glenn, 114-128. Palo Alto, CA: Stanford University Press, 2009.

Sue, Christina A. Land of the Cosmic Race: Race Mixture, Racism, and Blackness in Mexico. New York and Oxford: Oxford University Press, 2013.

Sue, Christina A. and Tanya Golash-Boza. "It Was Only a 'Joke': How Racial Humour Fuels Colour-Blind Ideologies in Mexico and Peru.” Ethnic and Racial Studies, 36 (2013): 1582-1598.

Swinton, William. Historia universal [Universal History]. In El Maestro, 2 (1921): 117122.

Telles, Edward (Ed.) Pigmentocracies: Ethnicity, Race, and Color in Latin America. Chapel Hill, NC: The University of North Carolina Press, 2014. 
Titscher, Stefan, Michael Meyer, Ruth Wodak and Eva Vetter. Methods of Text and Discourse Analysis: In Search of Meaning. Translated by Bryan Jenner. London: Sage Publications, 2000.

Torres-Saillant, Silvio. "Racism in the Americas and the Latino Scholar." In Neither Enemies nor Friends: Latinos, Blacks, Afro-Latinos, edited by Anani Dzidzienyo and Suzanne Oboler, 281-304. New York: Palgrave MacMillan, 2005.

Valencia Triana, Sayak. "Capitalismo gore: Narcomáquina y performance de género" [Slasher Capitalism: the Narco-Machine and Gender Performance]. e-misférica, 8 (2011), accessed February 15, 2017, http://hemisphericinstitute.org/hemi/es/e-misferica-82/triana. Van Dijk, Teun A. "Discourse and the Denial of Racism." Discourse \& Society (1992): $87-118$.

Van Dijk, Teun A. "Critical Discourse Analysis." In The Handbook of Discourse Analysis, edited by Deborah Schiffrin, Deborah Tannen and Heidi E. Hamilton, 352-371. Malden, MA: Blackwell Publishing, 2001.

Van Dijk, Teun. "Principles of Critical Discourse Analysis." In Discourse Theory and Practice: A Reader, edited by Margaret Wetherell, Stephanie Taylor and Simeonn J. Yates, 300-317. London: Sage Publications, 2001.

Vasconcelos, José. "Un llamado cordial” [A Cordial Calling]. El Maestro, 1 (1921): 5-9. Vasconcelos, José and Manuel Gamio. Aspects of Mexican Civilization. Chicago, IL: The University of Chicago Press, 1926.

Vasconcelos, José. El desastre [The Disaster]. (2 ${ }^{\text {nd }}$ ed.) Mexico: Fondo de Cultura Económica, 1982. 
Vasconcelos, José. La raza cósmica [The Cosmic Race]. (2 ${ }^{\text {nd }}$ ed.) Baltimore, MD: Johns Hopkins University Press, 1997.

Vaughan, Mary K. The State, Education, and Social Class in Mexico, 1880-1928.

DeKalb, IL: Northern Illinois University Press, 1982.

Vaughan, Mary K. Cultural Politics in Revolution: Teachers, Peasants, and Schools in Mexico, 1930-1940. Tucson, AZ: The University of Arizona Press, 1997.

Vaughan, Mary K. "Nationalizing the Countryside: Schools and Rural Communities in the 1930s." In The Eagle and the Virgin: Nation and Cultural Revolution in Mexico, 1920-1940, edited by Stephen E. Lewis and Mary K. Vaughan, 157-175. Durham and London: Duke University Press, 2006.

Vaughn, Bobby. "The African Diaspora Through Ojos Mexicanos: Blackness and Mexicanidad in Southern Mexico." The Review of Black Political Economy, (2005): 4957.

Vigil, James D. and Felipe Lopez. Race and Ethnic Relations in Mexico. The Journal of Latino-Latin American Studies, 1 (2004): 49-74.

Vinson III, Ben. "Black Mexico and the Historical Discipline.” In Black Mexico: Race and Society from Colonial to Modern Times, edited by Matthew Restall and Ben Vinson III, 1-15. Albuquerque, NM: University of New Mexico Press, 2009.

Wade, Peter. "Rethinking Mestizaje: Ideology and Lived Experience." Journal of Latin American Studies, 37 (2005): 239-257.

Wade, Peter. Race and Sex in Latin America. London: Pluto Press, 2009.

Wade, Peter. Race and Ethnicity in Latin America. (2 ${ }^{\text {nd }}$ ed.) London: Pluto Press, 2010. 
Wade, Peter. "La presencia de lo 'negro' en el mestizaje" [The Presence of "Blackness" in Mestizaje]. In Mestizaje, diferencia y nación: Lo "negro" en América central y el Caribe [Mestizaje, Difference and Nation: Blackness in Central America and the Caribbean], edited by Elisabeth Cunin, 107-127. Mexico: Instituto Nacional de Antropología e Historia, 2010.

Walsh, Casey. "Statistics and Anthropology: The Mexican Case." In A Companion to Latin American Anthropology, edited by Deborah Poole, 352-371. Malden, MA:

Blackwell Publishing, 2008.

Warman, Arturo. Los campesinos: Hijos predilectos del régimen. [Peasants: The Preferred Children of the State]. Mexico: Editorial Nuestro Tiempo, 1972. Warman, Arturo, Margarita Nolasco Armas, Guillermo Bonfil, Mercedes Olivera de Vazquez and Enrique Valencia. De eso que llaman antropología mexicana [Of that which They Call Mexican Anthropology]. Mexico: Editorial Nuestro Tiempo, 1970. Webb, Simon. "Masculinities at the Margins: Representations of the Malandro and the Pachuco." In Imagination Beyond Nation: Latin American Popular Culture, edited by Terry Caesar and Eva P. Bueno, 227-264. Pittsburgh, PA: University of Pittsburgh Press, 1998.

Widdifield, Stacie G. The Embodiment of the National in Late Nineteenth-Century Mexican Painting. Tucson, AZ: The University of Arizona Press, 1996.

Williams, Linda. "When the Woman Looks." In The Dread of Difference: Gender and the Horror Film, edited by Barry K. Grant ( $2^{\text {nd }}$ ed.), 17-36. Austin, TX: University of Texas Press, 2015. 
Winders, Jamie, John Paul J. III and Michael J Higgins. "Making Gueras: Selling White Identities on Late-Night Mexican Television." Gender, Place and Culture, 12 (2005): 7193.

Wise, Amanda and Selvaraj Velayutham. "Conviviality in Everyday Multiculturalism: Some Brief Comparisons Between Singapore and Sydney." European Journal of Cultural Studies, 17 (2014): 406-430.

Wright, Melissa. Disposable Women and Other Myths of Global Capitalism. New York and London: Routledge, 2006.

Wright, Melissa. "Necropolitics, Narcopolitics, and Femicide: Gendered Violence on the Mexico-US border.”Signs, 36(2011): 707-731.

Yankelevich, Pablo and Chenillo Alazraki, Paola. "La arquitectura de la política de inmigración en México" [The Construction of Immigration Policies in Mexico]. In Nación y extranjería: La exclusión racial en las políticas migratorias de Argentina, Brasil, Cuba y México [Nation and Otherness: Racial Exclusion in Immigration Policies in Argentina, Brazil, Cuba and Mexico], edited by Pablo Yankelevich, 187-230. Mexico: Universidad Nacional Autónoma de México, 2010. Young, Robert. Colonial Desire: Hybridity in Theory, Culture and Race. London and New York: Routledge, 1995.

Yuval-Davis, Nira. Gender and Nation. London: Sage Publications, 1997. 